U.S. Department of the Interior

U.S. Geological Survey

\title{
ROCKSLIDE-DEBRIS AVALANCHE OF MAY 18, 1980, MOUNT ST. HELENS VOLCANO, WASHINGTON
}

By Harry Glicken ${ }^{1}$

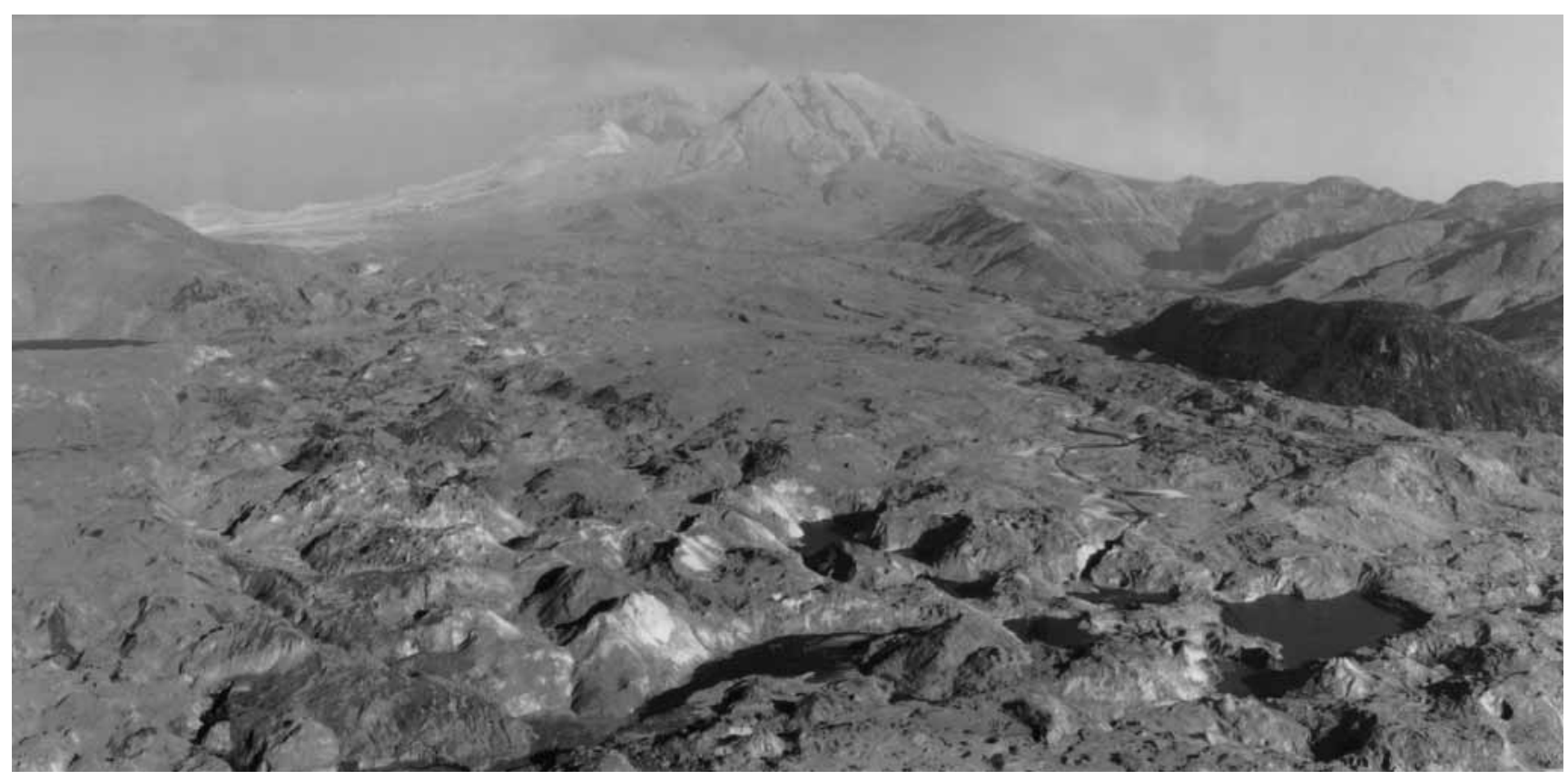

Open-file Report 96-677

${ }^{1}$ Cascades Volcano Observatory, Vancouver, WA 98661 


\section{U.S. DEPARTMENT OF THE INTERIOR U.S. GEOLOGICAL SURVEY}

Rockslide-debris avalanche of May 18, 1980, Mount St. Helens volcano, Washington

By

Harry Glicken ${ }^{1}$

Open File Report 96-677

This report is preliminary and has not been reviewed for conformity with U.S. Geological Survey editorial standards or with the North American Stratigraphic Code. Any use of trade, firm, or product names is for descriptive purposes only and does not imply endorsement by the U.S. Government.

${ }^{1}$ Cascades Volcano Observatory, 5400 MacArthur Blvd., Vancouver, WA, 98661 


\section{PREFACE}

Harry Glicken died on June 3, 1991. At the time of his death he was actively working to convert his doctoral dissertation into a publication more readily fit for public consumption. Harry published bits and pieces of his dissertation in various outlets. These publications include:

Voight, Barry, Glicken, Harry, Janda, R.J., and Douglass, P.M., 1981, Catastrophic rockslide avalanche of May 18, in Lipman, P.W., and Mullineaux, D.R., 1981, eds., The 1980 eruptions of Mount St. Helens, Washington: U.S. Geological Survey Professional Paper 1250, p. 347-377.

Voight, Barry, Janda, R.J., Glicken, Harry, and Douglass, P.M., 1983, Nature and mechanics of the Mount St. Helens rockslide-avalanche of 18 May 1980: Geotechnique, v. 33, p. 243-273.

Glicken, Harry, Meyer, William, and Sabol, Martha A., 1989, Geology and ground-water hydrology of Spirit Lake blockage, Mount St. Helens, Washington, with implications for lake retention: U.S. Geological Survey Bulletin 1789, 33 p.

Glicken, Harry, 1990, The rockslide-debris avalanche of the May 18, 1980, eruption of Mount St. Helens--10th anniversary perspectives: Geoscience Canada, v. 17, p. 150-153.

Glicken, Harry, 1991, Sedimentary architecture of large volcanic-debris avalanches, in Fisher, R.V. and Smith, G.A., eds., Sedimentation in Volcanic Settings. SEPM Special Publication No. 45, p. 99-106.

Komorowski, J.C., Glicken, H.X, and Sheridan, M.F., 1991, Secondary electron imagery of microcracks and hackly fracture surfaces in sand-size clasts from the 1980 Mount St. Helens debris-avalanche deposit; implications for particle-particle interactions: Geology, v. 19, p. 261264.

The full scope of Harry's work, however, has never been published. Nevertheless, it has greatly influenced the study of volcanic debris avalanches worldwide. Following the 1980 eruption of Mount St. Helens, debris avalanches suddenly were recognized at numerous volcanoes around the globe; criteria for recognition of debris avalanches, which Harry defined, have been used in numerous studies. His profound influence on studies of debris avalanches is evident in the many papers Harry coauthored on debris avalanches at other volcanoes, in various references to his Mount St. Helens work, and in acknowledgments to his input found in many papers on debris avalanches published since 1980.

The complete scope of Harry's study of the Mount St. Helens debris avalanche is contained in this publication. It represents the most complete and detailed investigation of a volcanic debris avalanche conducted to date. In this publication, Harry carefully lays out the geology of the former edifice of Mount St Helens, and the intricate, and sometimes chaotic, geology of the debris-avalanche deposit. He then links the geology of the mountain and features of the debris-avalanche deposit through careful geologic correlation combined with eyewitness observations. By combining careful geologic analysis with detailed eyewitness observations Harry is able to reconstruct the first several minutes of the catastrophic May 18, 1980 eruption and to provide insights into the transport mechanisms of the mass movement.

Perhaps the greatest contribution of this publication is the construction of detailed geologic maps of the debris-avalanche deposit. These maps illustrate in meticulous detail where various segments of the old edifice came to rest, how some segments were transported intact, how other segments blended and mixed together, and associations between the rockslide-debris avalanche and other volcanic processes such as the devastating lateral blast and the lahar of the North Fork Toutle River valley. Nowhere before has a deposit of this type been mapped in such detail. Furthermore, the Mount St. Helens deposit will never be mapped in such detail again. The deposit gradually is being eroded as the North Fork Toutle River channel 
evolves. While some exposures are better than they were when Harry mapped the deposit, others no longer exist.

This publication reflects the work embodied in Harry's doctoral dissertation; however, owing to his tragic death, some modifications had to be made. The astute reader will recognize that the deposit geology on the lithologic maps does not correspond exactly to the base topography. Harry mapped the deposit lithology on a 1:12,000-scale base map constructed from a mosaic of specially made 1:4800-scale topographic maps. Unfortunately, the original base map was lost following Harry's death, and it became cost prohibitive to reconstruct that base map from the 1:4800 scale maps. We therefore compromised by overlaying Harry's detailed lithologic maps of the debris avalanche onto 1:24,000-scale topographic maps, compiled from 1980 photography, that were blown up to a 1:12,000 scale. This compromise presents a reasonable rendition of the geology of the debris-avalanche deposit with little loss of detail. In addition to this modification of the original maps I have updated, and in some cases added, citations to references where relevant.

Bringing Harry's work to publication has involved the efforts of many people. Foremost among these is Carol Ostergren, formerly an editor with the U.S. Geological Survey technical reports division. Carol refused to let this work wither away following Harry's death. This publication reflects her tenacity as much as anything else. John Costa and Dan Dzurisin of the Cascades Volcano Observatory felt that this was a sufficiently important piece of work to publish and provided the time and personnel necessary to see that it was published. Steve Schilling, Lisa Faust, Bobbie Myers, and Chris Janda tolerated my endless demands and spent many hours processing geologic maps, line art, photographs, and page layout. I am grateful for their willingness to involve themselves in this project and for the thoroughness they brought to their tasks. 


\section{CONTENTS}

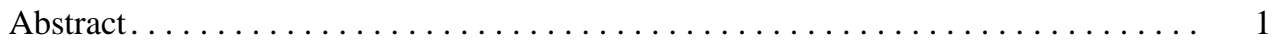

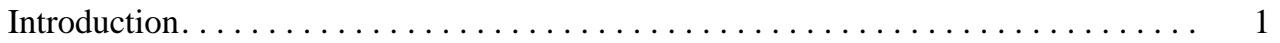

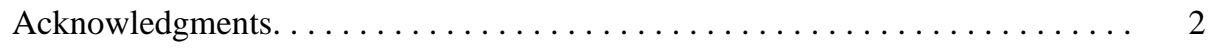

Geology of the source area $\ldots \ldots \ldots \ldots \ldots \ldots \ldots \ldots \ldots \ldots \ldots \ldots \ldots \ldots \ldots$

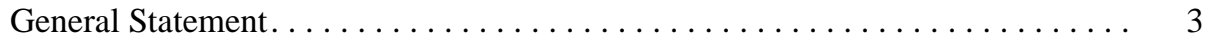

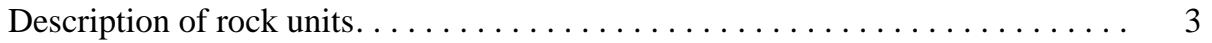

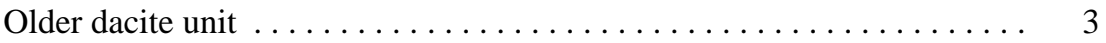

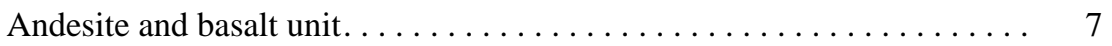

Modern dacite unit. . . . . . . . . . . . . . . . . . . 7

Cryptodome ............................ 8

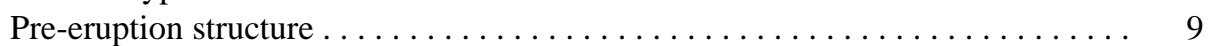

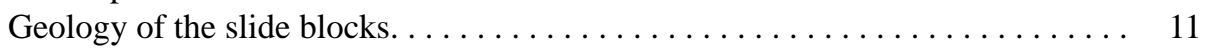

Geometry of the deposit $\ldots \ldots \ldots \ldots \ldots \ldots \ldots \ldots \ldots \ldots \ldots \ldots \ldots \ldots \ldots$

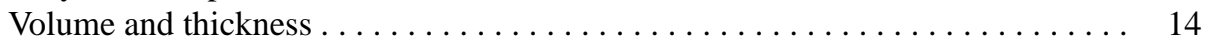

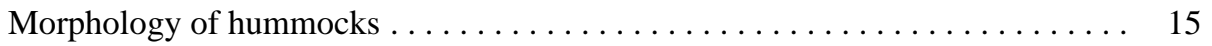

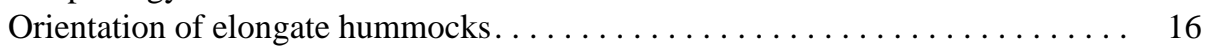

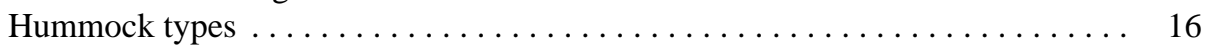

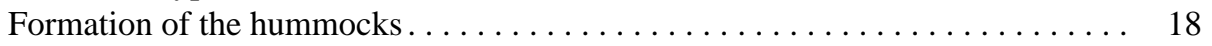

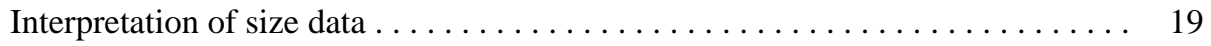

Geologic maps of the deposit $\ldots \ldots \ldots \ldots \ldots \ldots \ldots \ldots \ldots \ldots \ldots \ldots \ldots \ldots \ldots$

General statement . . . . . . . . . . . . . . . . . . . . . . 19

Morphologic map of the debris-avalanche deposit. . . . . . . . . . . . 21

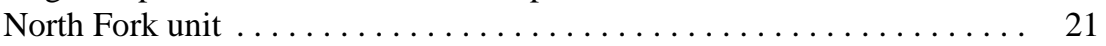

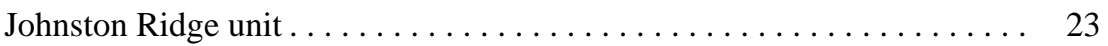

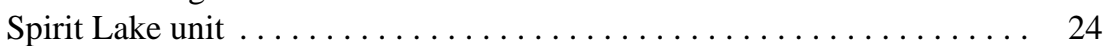

Marginal unit .............................. 24

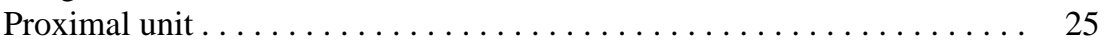

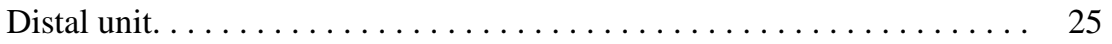

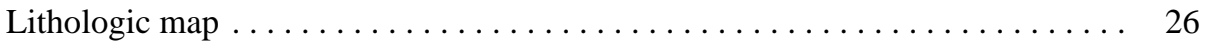

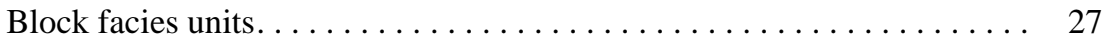

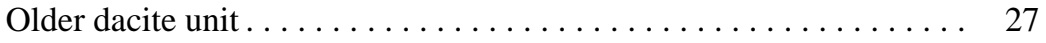

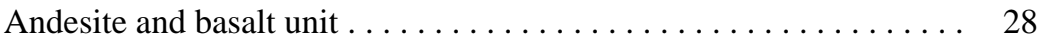

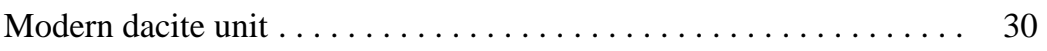

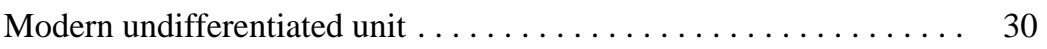

Mixed block and matrix facies unit ................ 32

Contacts between lithologic units . . . . . . . . . . . . . . 33

Other deposits of the May 18,1980 eruption $\ldots \ldots \ldots \ldots \ldots \ldots \ldots \ldots \ldots$

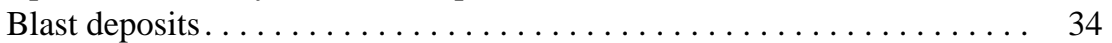

Lahar deposits . . . . . . . . . . . . . . . . . . . . 37

Pyroclastic flow deposits of the afternoon of May $18 \ldots \ldots \ldots \ldots 38$

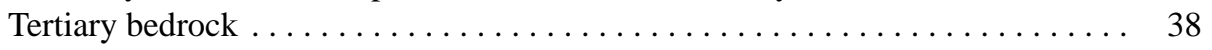

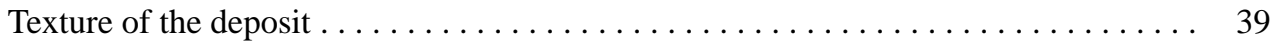

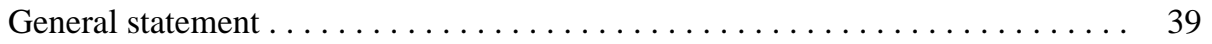

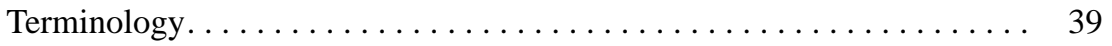

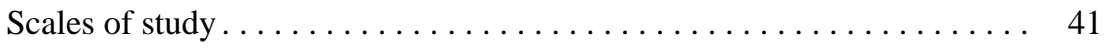

Textural interpretation of map relations $\ldots \ldots \ldots \ldots \ldots \ldots \ldots \ldots \ldots \ldots \ldots . \ldots 1$

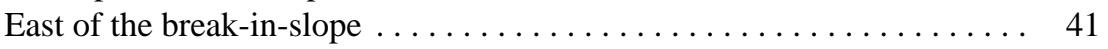

West of the break-in-slope . . . . . . . . . . . . . . . . 42

Lateral variation in debris-avalanche block size . . . . . . . . . . . . 42

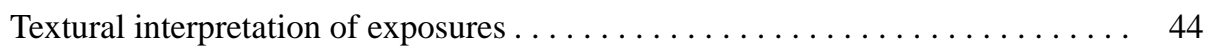

General statement ......................... 44 


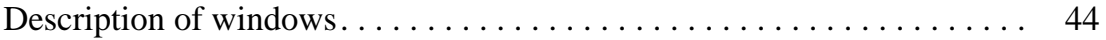

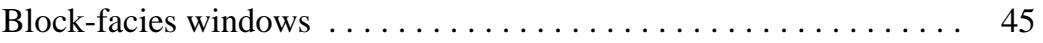

Block- and matrix-facies windows ................ 53

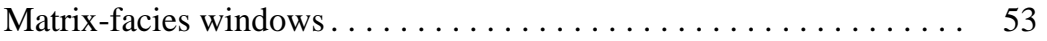

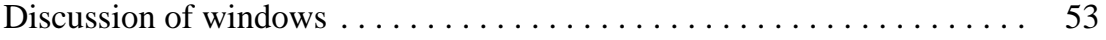

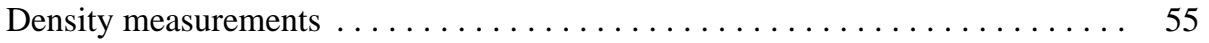

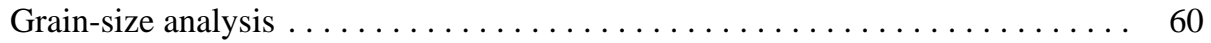

Methods .................................. 60

Results ................................ 67

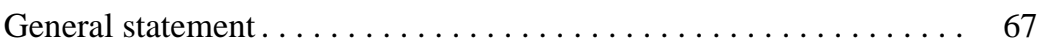

Distribution plots ...................... 67

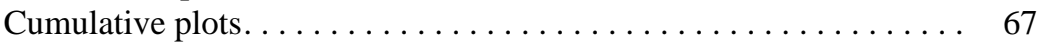

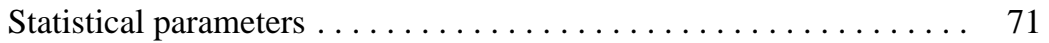

Lateral variations of statistical parameters . . . . . . . . . . 72

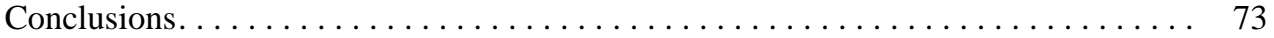

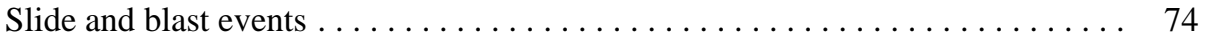

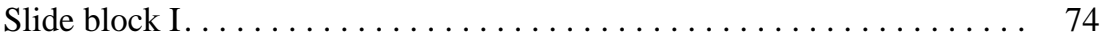

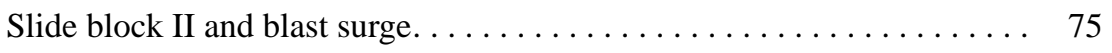

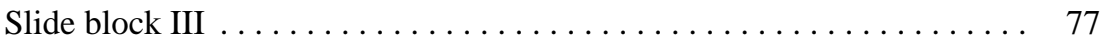

Final events . . . . . . . . . . . . . . . . . . . . 79

Water budget . . . . . . . . . . . . . . . . . . . . . . . . 80

Transition to flow and disintegration of material $\ldots \ldots \ldots \ldots \ldots \ldots \ldots$

Fluidization and fluids in the flow $\ldots \ldots \ldots \ldots \ldots \ldots \ldots \ldots \ldots \ldots$

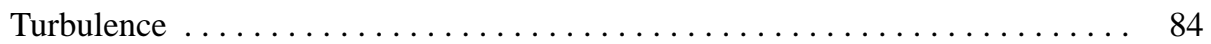

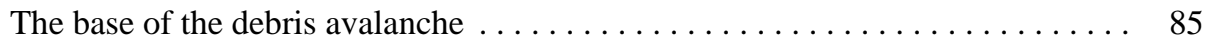

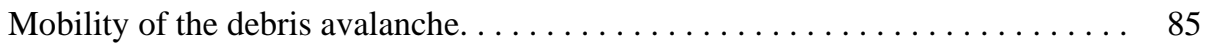

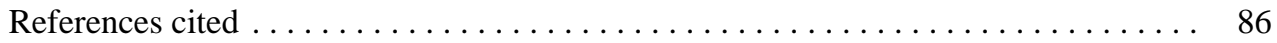

\section{PLATES}

[Plates are in pocket]

1. Isopach map of debris-avalanche deposit

2. Orientations of long axes of hummocks in the debris-avalanche deposit

3. Morphologic map of debris-avalanche deposit

4. Lithologic map of debris-avalanche deposit

5. Lithologic cross sections of debris-avalanche deposit

\section{FIGURES}

Frontispiece. Panorama of debris-avalanche deposit, July 31, 1980

1. Topographic map of volcanic edifice and crater formed on May $18,1980 \ldots \ldots \ldots \ldots$

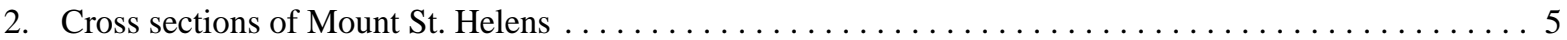

3. Eruptive periods of Mount St. Helens that produced rocks in debris avalanche $\ldots \ldots \ldots \ldots \ldots$

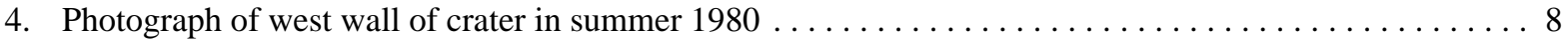

5. Photographs of hand samples of rock from the old mountain $\ldots \ldots \ldots \ldots \ldots \ldots$

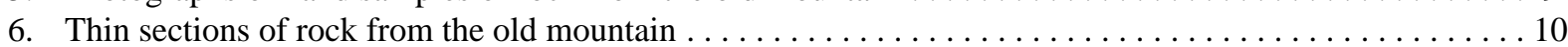

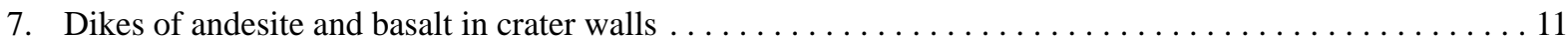

8. Ternary diagram of orthopyroxene, clinopyroxene, and hornblende+opaques for modern dacite dome rocks $\ldots \ldots \ldots \ldots \ldots \ldots \ldots \ldots \ldots \ldots$

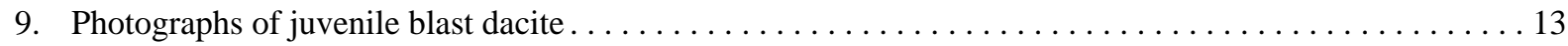




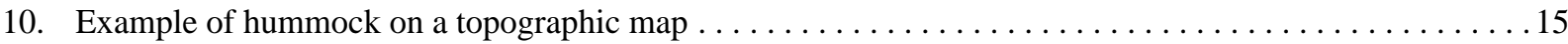

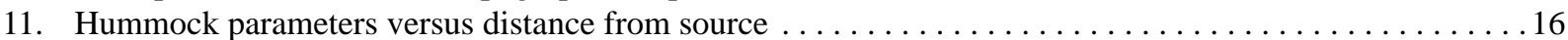

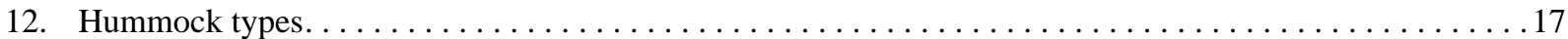

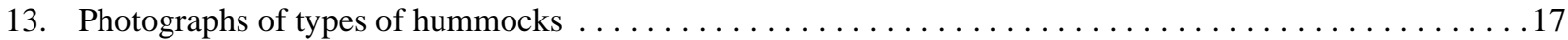

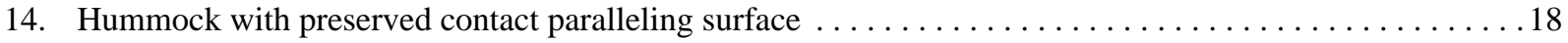

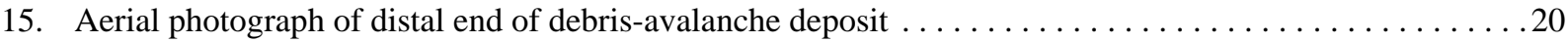

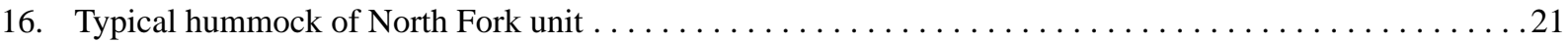

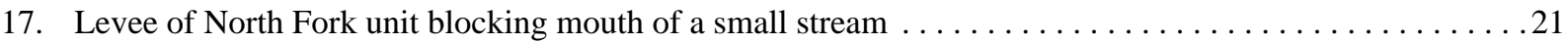

18. Aerial photograph of debris-avalanche deposit in area around Castle and Coldwater Lakes...........22

19-21. Photographs showing:

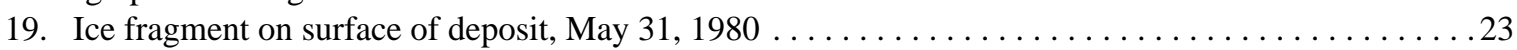

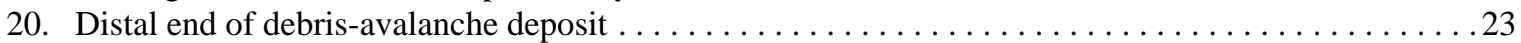

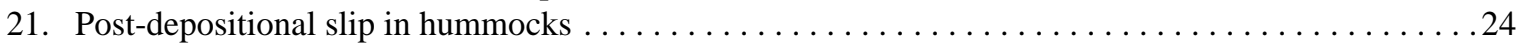

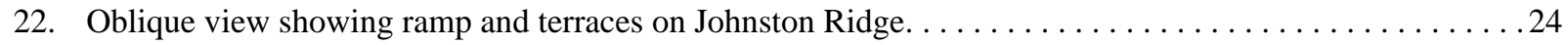

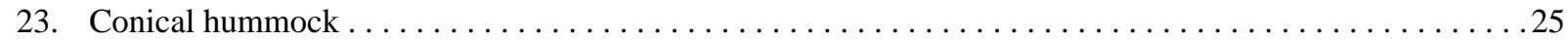

24. Oblique aerial photograph of lobate deposits of marginal unit .......................... 26

25-34. Photographs showing:

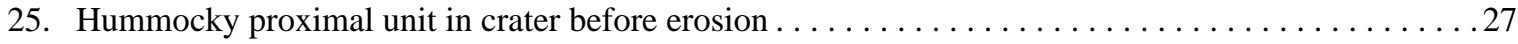

26. Hummocks of proximal unit on north flank of Mount St. Helens. . . . . . . . . . . . . . 27

27. Scratches resembling glacial striations on north flank of Mount St. Helens . . . . . . . . . . . 28

28. Jumbled hummocks of woody debris in distal unit . . . . . . . . . . . . . . . . . . . 28

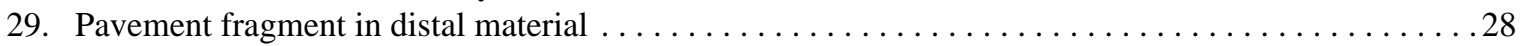

30. Dipping contact between distal and North Fork units . . . . . . . . . . . . . . . . . . . . 29

31. Narrow and elongate volcanic dikes in debris-avalanche deposit cross cut by faults . . . . . . . . . 29

32. Volcanic dike and clastic dike in hummock of debris-avalanche deposit . . . . . . . . . . . . . . 29

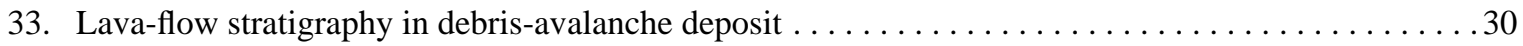

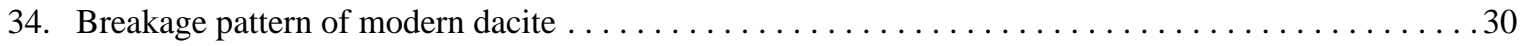

35. Percentage of clasts of juvenile blast dacite versus distance from source $\ldots \ldots \ldots \ldots \ldots \ldots \ldots \ldots \ldots \ldots \ldots \ldots \ldots$

36. Oblique aerial photograph of debris-avalanche deposit showing break-in-slope $\ldots \ldots \ldots \ldots \ldots \ldots \ldots$

37-40. Photographs showing:

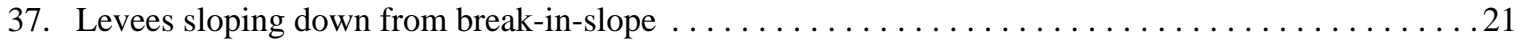

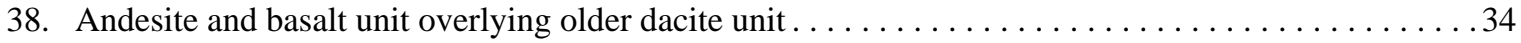

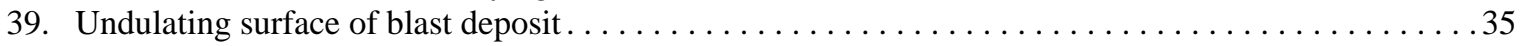

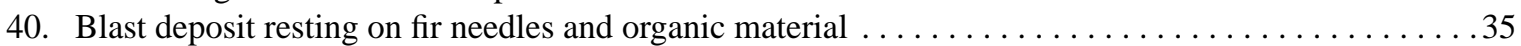

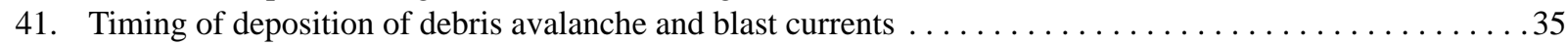

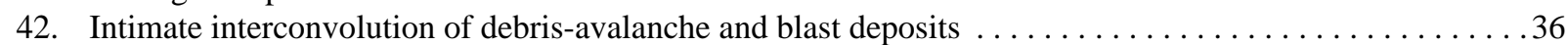

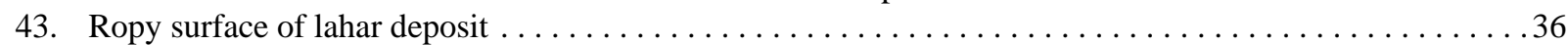

44. Oblique aerial photographs of moving lahars near North Fork Toutle River

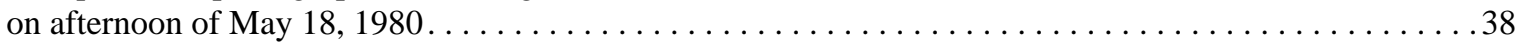

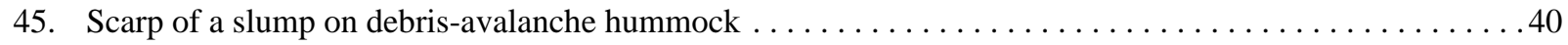

46. Hummock made of one debris-avalanche block in andesite and basalt unit. . . . . . . . . . . . . 41

47. Aerial photograph showing enigmatic textural pattern on southern half of deposit . . . . . . . . . . 43

48. Volume of identified largest debris-avalanche blocks in $1-\mathrm{km}^{2}$ areas

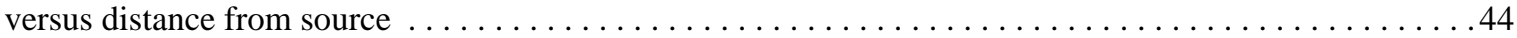

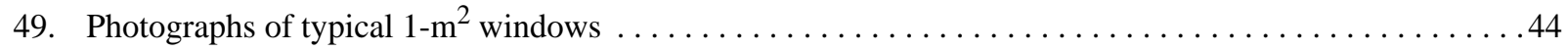

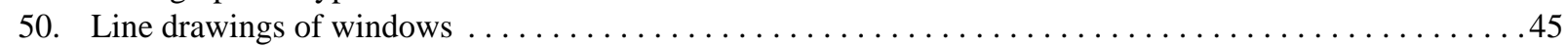

51. Photograph and graph showing sand-cone test and density of debris-avalanche deposit

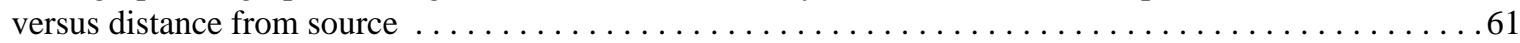

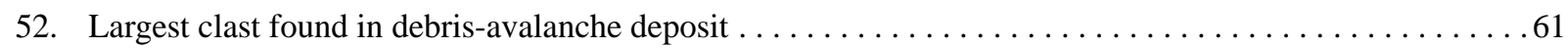

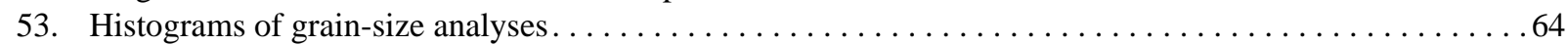

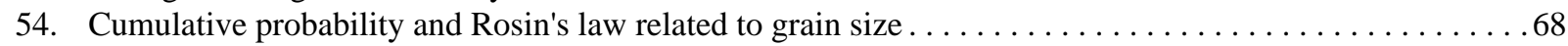

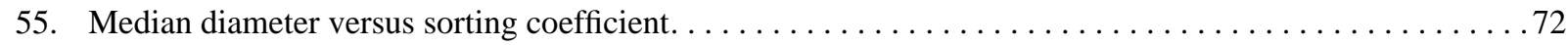

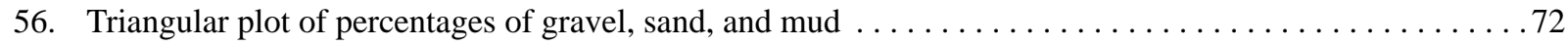

57-59. Graphs showing:

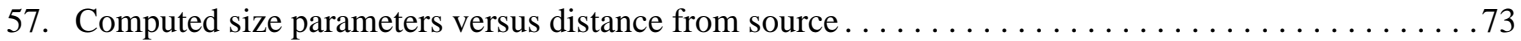


58. Percentage of size classifications versus distance from source $\ldots \ldots \ldots \ldots \ldots \ldots \ldots \ldots \ldots \ldots \ldots$

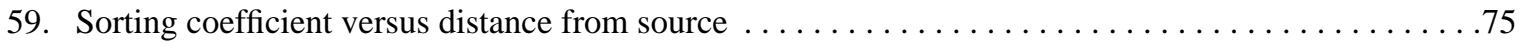

60. Generalized lithologic map of debris-avalanche deposit, showing

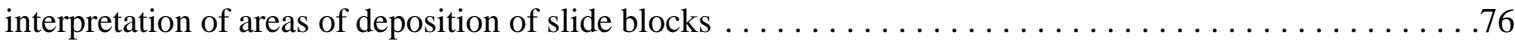

61. Summary of processes involved in transport of rockslide-debris avalanche $\ldots \ldots \ldots \ldots \ldots \ldots \ldots \ldots 77$

62. Oblique aerial photograph showing interpreted paths of slide blocks. $\ldots \ldots \ldots \ldots \ldots \ldots \ldots \ldots \ldots .78$

63. Schematic cross sectional diagram showing flow of debris-avalanche

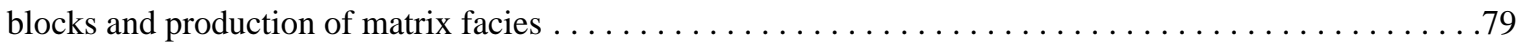

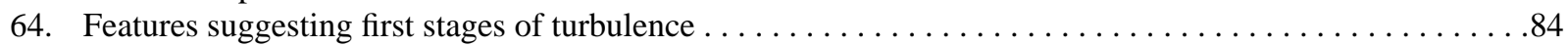

65. Mobility versus volume for volcanic and nonvolcanic debris avalanches $\ldots \ldots \ldots \ldots \ldots \ldots \ldots \ldots . .85$

\section{TABLES}

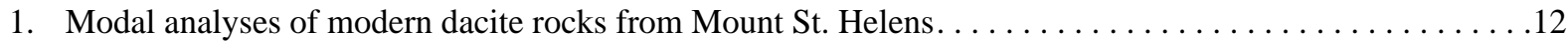

2. Slide blocks in each cross section and geologic units in each slide block. . . . . . . . . . . . . . . 14

3. Lithologic counts of approximately 100 clasts $>2 \mathrm{~cm}$ diameter in $1-\mathrm{m}^{2}$ windows $\ldots \ldots \ldots \ldots \ldots \ldots$

4. Distance from source, density, grain-size, and sorting parameters for

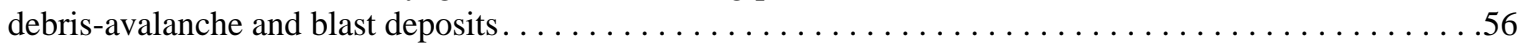

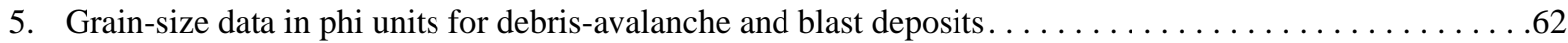

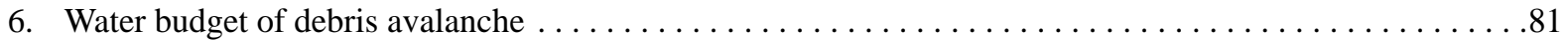

\section{GLOSSARY}

Block facies. The part of the debris-avalanche deposit that consists of debris-avalanche blocks.

Clast. A rock of any size that would not break if passed through a sieve or immersed in water.

Debris-avalanche block. An unconsolidated (or poorly consolidated) piece of the old mountain transported to its place of deposition relatively intact. Contains many clasts that range in size from microns to meters.

Dilation. The volume expansion of a mass of material.

Disaggregation. The breaking apart of unconsolidated or poorly consolidated material into its constituent clasts.

Fracturing. The breaking of individual clasts.

Matrix facies. A part of the debris-avalanche deposit that is completely mixed. Contains all rock types from the old mountain, the juvenile dacite, and some material picked up from surrounding terrain. Contains clasts of all sizes from microns to meters.

Particle. A separable or distinct unit in the deposit or the moving material.

Shattering. The thorough fracturing of clasts.

Slide block. A mass of the original rockslide visible on the eyewitness photographs. Rockslide divided into slide blocks I, II, and III; slide block III is a composite of many discrete failures.

Texture. The size, shape, and fabric (pattern of arrangement) of particles that form the deposit. 


\title{
ROCKSLIDE-DEBRIS AVALANCHE OF MAY 18, 1980, MOUNT ST. HELENS VOLCANO, WASHINGTON
}

\author{
By Harry Glicken
}

\begin{abstract}
This report provides a detailed picture of the rockslide-debris avalanche of the May 18, 1980, eruption of Mount St. Helens volcano. It provides a characterization of the deposit, a reinterpretation of the details of the first minutes of the eruption of May 18, and insight into the transport mechanism of the mass movement.

Details of the rockslide event, as revealed by eyewitness photographs, are correlated with features of the deposit. The photographs show three slide blocks in the rockslide movement. Slide block I was triggered by a magnitude 5.1 earthquake at 8:32 a.m. Pacific Daylight Time (P.D.T.). An exploding cryptodome burst through slide block II to produce the "blast surge." Slide block III consisted of many discrete failures that were carried out in continuing pyroclastic currents generated from the exploding cryptodome. The cryptodome continued to depressurize after slide block III, producing a blast deposit that rests on top of the debris-avalanche deposit.

The hummocky $2.5-\mathrm{km}^{3}$ debris-avalanche deposit consists of block facies (pieces of the pre- eruption Mount St. Helens transported relatively intact) and matrix facies (a mixture of rocks from the old mountain and cryptodome dacite). Block facies is divided into five lithologic units. Matrix facies was derived from the explosively generated current of slide block III as well as from disaggregation and mixing of debris-avalanche blocks.

The mean density of the old cone was measured to be about 20 percent greater than the mean density of the avalanche deposit. Density in the deposit does not decrease with distance which suggests that debris-ava-
\end{abstract}

lanche blocks were dilated at the mountain, rather than during transport. Various grain-size parameters that show that clast size converges about a mean with distance suggest mixing during transport.

The debris-avalanche flow can be considered a grain flow, where particles--either debris-avalanche blocks or the clasts within the blocks--collided and created dispersive stress normal to the movement of material. The dispersive stress preserved the dilation of the material and allowed it to flow.

\section{INTRODUCTION}

The May 18, 1980, eruption of Mount St. Helens was one of the most important geologic events of the century. The eruption produced the largest mass movement in recorded history. The explosion that resulted from the depressurization of the volcano devastated the surrounding landscape and killed 53 people, and the subsequent Plinian eruption produced tephra that spread around the world.

The eruption provided an unprecedented opportunity to understand the processes occurring during a major volcanic eruption. This report is the summary of one of the studies that capitalized on that opportunity. The study involved detailed field and laboratory work on the 2.5$\mathrm{km}^{3}$ deposit of the rockslide-debris avalanche that was one of the initial events of May 18. Combining this work with studies of the geology of the old mountain (C.A. Hopson, written communication, 1980) and studies of eyewitness photographs of the first moments of the eruption (Voight, 1981; Foxworthy and Hill, 1982; Moore and Rice, 1984) this report tells much of the story of how the volcano fell and blasted apart. It builds upon preliminary work by Voight and others $(1981,1983)$. 
Large volcanic debris avalanches are not uncommon around volcanoes (Siebert, 1984) but they are not well understood. The 1980 debris avalanche at Mount St. Helens is the best exposed of these deposits. This detailed study of the geology of the 1980 Mount St. Helens deposit should provide information that will help interpret old, poorly-exposed deposits at volcanoes around the world.

The work also provides information that will help in understanding the transport of large $\left(>1 \mathrm{~km}^{3}\right)$, non-volcanic mass movements. Although many of these mass movements have occurred in historic and prehistoric time (Voight, 1978) little detailed work has been done on the resulting deposits.

I attempt to answer specific questions that are important to the general problem of how the volcano collapsed and blasted apart. Those questions include:

What was the nature of the earthquake-triggered rockslide that was the first event of the May 18, 1980 eruption of Mount St. Helens? Was it complicated by the sudden depressurization of the volcano's magmatic and hydrothermal system (the lateral blast)? What parts of the old mountain fell away, and where were they deposited?

What was the role of water and gas in the transport of the material? Was the material fluidized? Was it turbulent?

How did the material break up from its source on the mountain to its place of deposition? How did the material transform from a slide to a flow? How important were grain-grain interactions in the movement? What accounts for the production of the mixed "matrix facies?" What accounts for the relatively long travel distance of the material?

Many different data sets are used to answer these questions. Some rely on traditional methods. The geology of the source area was compiled, primarily from the work of C.A. Hopson (University of California, written commun., 1980). The deposit was mapped at a scale of 1:24,000, and six morphologic units were identified. A detailed lithologic map of facies and rock types in the deposit at a scale of 1:12,000 was compiled in order to determine the resting places of various pieces of the old mountain and to determine their sequence of deposition. Stratigraphic relationships helped in the understanding of the relationship of the rockslide-debris avalanche to the lateral blast and the other events of May 18.

Other data sets were compiled by studying individual exposures in much greater detail than is common in geologic field work. Forty-four $1-\mathrm{m}^{2}$ exposures of the debris-avalanche deposit were cleared of slope wash and examined in detail. The facies and rock types in the exposures were mapped and the large clasts were measured and identified. The field density of the exposures was measured by the sand-cone technique. Laboratory grain-size analyses were run on samples from the exposures. The data on exposures provided information on the breakup of the material at the mountain and during transport.

Aerial photographs and topographic maps of the uneroded deposit are important data sets, and they were also studied in detail. The post-eruption maps were compared to the pre-eruption maps in order to construct an isopach map. Various morphologic parameters were measured from the maps in order to quantify the description of the morphology of the deposit.

Although selected problems are emphasized in this work, the detailed description of the deposit is a major contribution of the study. There is no large volcanic debris avalanche deposit in the world that has been studied in as much detail as this one.

\section{ACKNOWLEDGMENTS}

I am indebted to R.V. Fisher, my principal advisor in this work, for providing training, encouragement, advice, and funding. I am also indebted to my other advisors, Barry Voight, Dick Janda, Cliff Hopson, and Ed Keller. These men started me, guided me, and shared their wealth of experience in various aspects of earth science.

The U.S. Geological Survey has provided funding, logistical support, and an office in a volcano observatory that has served as a second university for me; without these, this effort would have been considerably less thorough. Bob Christiansen, Don Swanson, Don Peterson, Dick Janda, Chris Newhall, Bill Meyer, Bob Schuster, and Patrick Muffler risked the investment in me on just the hope that good science would come of it.

I am grateful to all of the people who have helped me in the field and in the office, many only for the opportunity to share in the excitement of the science. These people include Mindy Brugman, Cindy Heliker, Dave Harris, Chris Carlson, Dan May, Mike Doukas, Dick Tosdal, Martha Sabol, Dan Johnson, Ted Bornhorst, Lisa McBroome, Cy Field, Ann Smith, Pat Pringle, Sue Shiply, Steve Anderson, Carol Schifflet, Kathy Cashman, Carolyn Driedger, Sharon Diehl, Craig Prentice, Stephanie Reiss, Chris Wilson, Art Vaughan, Bill Chadwick, Jeff Gerwe, Cindy Stine, Becky Linville, Diane Smith, Gary Stoopes, and Robin Sutton.

Many scientists who share my enthusiasm for volcanic sediment have provided helpful hints at all stages of this work. These people include Lee Siebert, Rick Hoblitt, Rocky Crandell, Dan Miller, Chris Newhall, Bill 
Criswell, Jon Major, Kevin Scott, Hans Schmincke, Richard Waitt, Wolf Elston, Mike Sheridan, Ian Nairn, Bill Rose, Mike Malin, Dave Meyer, Hiromitsu Yamagishi, Norm MacLeod, Steve Finneran, Paul Delaney, Bruce Houghton, Sutikno Bronto, Colin Wilson, George Walker, Keiko Suzuki, Roger Denlinger, Holly Martinson, Dick Iverson, Tom Pierson, Lisa McBroome, Kent Sundell, Tom Sisson, Jim Moore, Sue Kieffer, Robin Holcomb, Koji Mimura, Yoichi Nakamura, Karen Gilkie, Cathy Busby-Spera, Bob Christiansen, Steve Self, and Tad Ui. I owe an especial debt to Tad, who has provided an international perspective that has been invaluable in the study of the deposit.

\section{GEOLOGY OF THE SOURCE AREA}

\section{GENERAL STATEMENT}

The source of the rockslide-debris avalanche is the cone of Mount St. Helens. The $2.8-\mathrm{km}^{3}$ crater (fig. 1) was formed during the May 18 eruption as a result of the failure of the edifice because of the rockslide and the associated lateral blast. The geology of the volcano was mapped by C.A. Hopson (written commun., 1980) before 1980, and the walls of the crater were mapped by Hopson after the eruption (Hopson and Melson, 1982; written commun., 1984). Smith (1984) and Smith and Leeman (1987) studied the petrography and geochemistry of some of the pre-1980 rocks.

The work of these authors is summarized here to provide a guide to the rocks within the debris-avalanche deposit. In addition, cross-sections of the mountain as it was just before the eruption (fig. 2) were constructed using Hopson's work and pre-May 18 deformation data (Lipman and others, 1981; Moore and Albee, 1981; Jordan and Kieffer, 1981).

Three units are differentiated in the part of the pre1980 mountain that became the debris-avalanche deposit (fig. 3). The units are generalized from previous geologic work (Hopson and Melson, 1982; Mullineaux and Crandell, 1981). The older dacite unit makes up the core of the old mountain, forming the light-colored exposures in the crater below an altitude of about 7,000 to 7,500 ft $(2,100$ to $2,300 \mathrm{~m})$, and it is overlain by the dark-colored andesite and basalt unit (fig. 4). The Goat Rocks and Summit domes, removed during the rockslide-debris avalanche, make up the modern dacite unit. The three pre1980 units were intruded by a dacite magma body (called the cryptodome) in the weeks prior to the May 18 eruption.

\section{DESCRIPTION OF ROCK UNITS}

\section{OLDER DACITE UNIT}

Hornblende-hypersthene dacite makes up the lightcolored exposures in the crater below an altitude of about $7,000-7,500 \mathrm{ft}$ (2,100 to 2,300 m). The rock consists of a complex assemblage of fresh and hydrothermally altered dome lavas and dome flank breccias (C.A. Hopson, written commun., 1984) that make up the core of Mount St. Helens (fig. 2). This older foundation of Mount St. Helens was first recognized by Verhoogen (1937), who referred to the older dacite as "the old Mount St. Helens lavas."

The older dacite rocks in the crater are not dated. By correlation with exposures on the outside of the crater and stratigraphic position under andesites and basalts dated by paleomagnetic and radiocarbon methods, the older dacite unit is assigned an age of pre-Castle Creek (fig. 3), older than 2,500 years (Hopson and Melson, 1982). Most of the older dacite in the crater is likely of Pine Creek age, 2,500 to 3,000 years old (C.A. Hopson, written commun., 1986).

The older dacite rocks are hornblende-hypersthene dacite with abundant large ( $>2 \mathrm{~mm}$ length) phenocrysts of plagioclase and hornblende (figs. 5 and 6) and smaller but more abundant hypersthene. The rocks contain inclusions of varying composition that are similar in appearance to the primarily gabbroic inclusions of the Mount St. Helens 1980-84 dome (Heliker, 1984; 1995).

The older dacite in the crater is locally altered to various shades of green, pink, yellow, and gray. Probable equivalent rocks in the debris-avalanche deposit, analyzed by Pevear and others (1982) using scanning electron microscopy (SEM) and X-ray powder diffraction techniques, contain smectite as the dominant clay mineral, although mixed-layer chlorite/smectite and chlorite also are present. The dominance of smectite indicates that the hydrothermal alteration occurred at temperatures generally below $200{ }^{\circ} \mathrm{C}$, and that the smectite was likely the result of long-term hydrothermal alteration (Pevear and others, 1982). There are also the silica polymorphs tridymite, cristobalite, and quartz in the $<2 \mu \mathrm{m}$ fraction, and they may be primary groundmass phases, vapor phases, or products of hydrothermal or fumarolic alteration at low temperatures (Pevear and others, 1982; C.A. Hopson, written commun., 1984).

Andesite, basalt, and subordinate dark-colored dacite dikes tens of centimeters to meters wide are common features of the crater walls (fig. 7). The dikes, which intrude the older dacite unit to feed the overlying andesite and basalt flows, are commonly jointed, faulted, and fractured. 


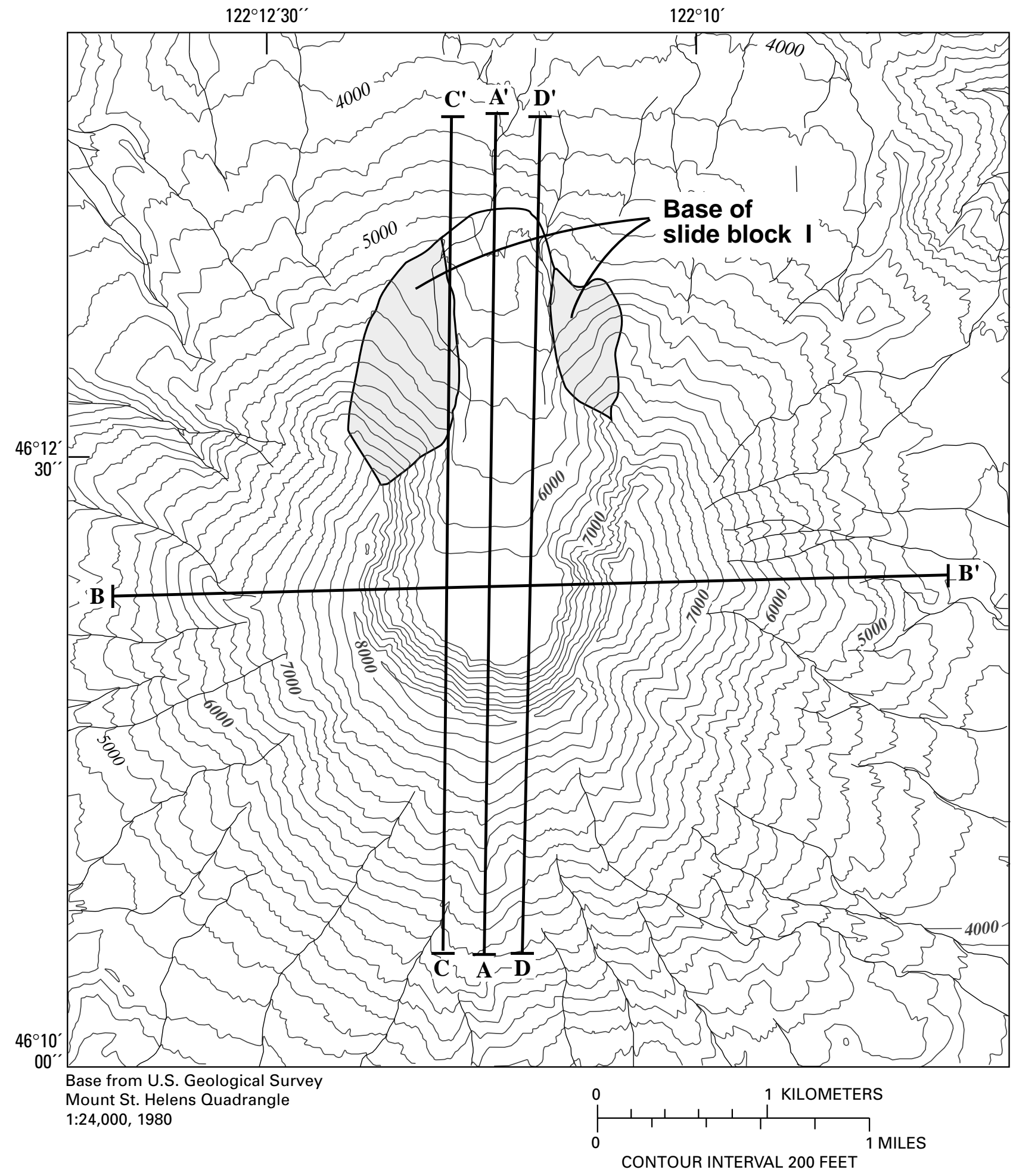

Figure 1. Topographic map of volcanic edifice and crater formed on May 18, 1980. Map shows inferred base of slide block I, and locations of cross sections $A-A^{\prime}, B-B^{\prime}, C-C^{\prime}, D-D^{\prime}$ of figure 2. Base from Mount St. Helens quadrangle map (1:24,000 scale; map date 1983), which shows summer 1980 topography. Contour interval 200 feet. 

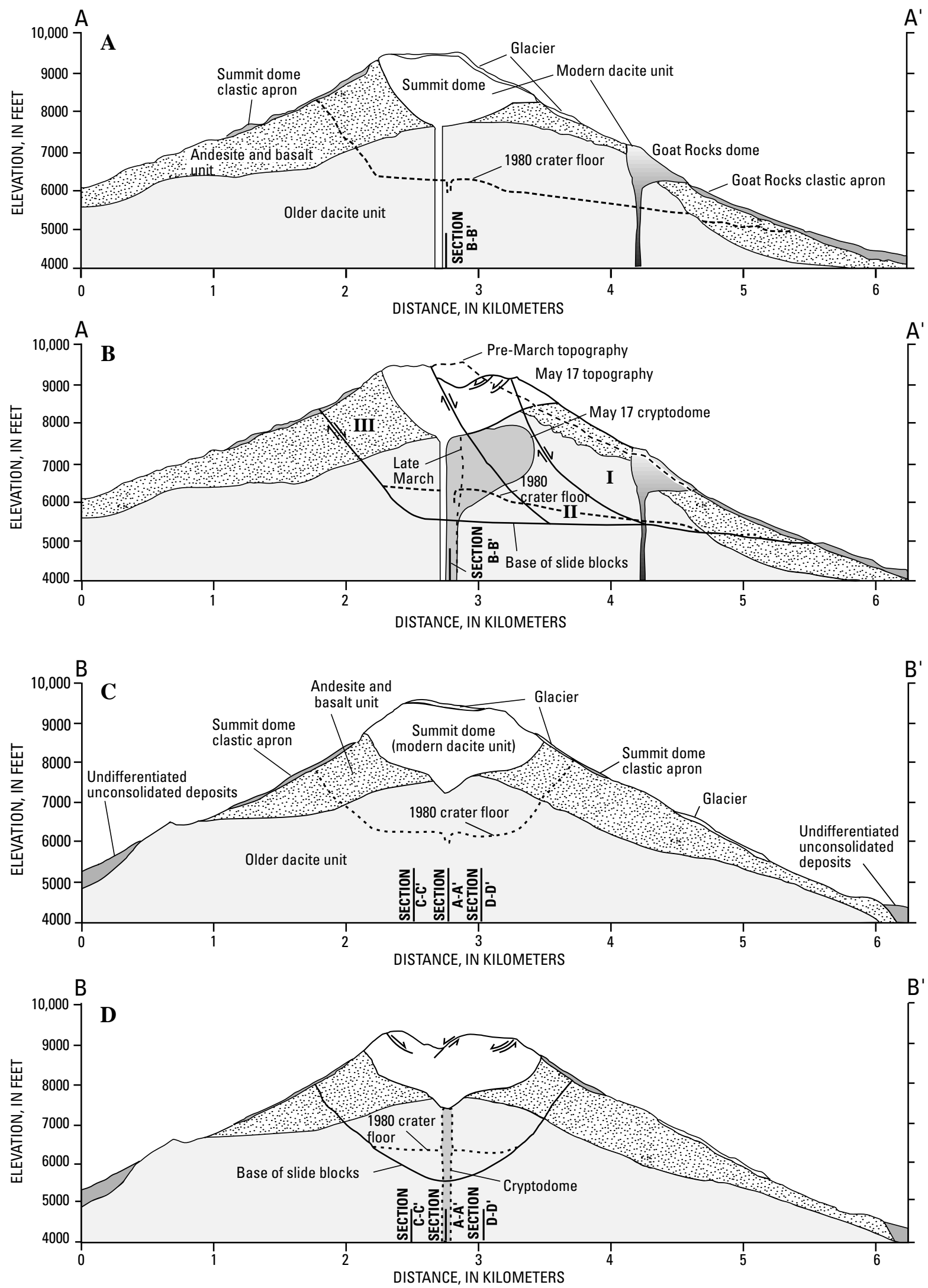

Figure 2. Cross sections of Mount St. Helens. I,II,III are slide blocks. Locations on figure 1 . A, $A-A^{\prime}$ pre-March 1980 . B, $A-A^{\prime}$ at time of failure, 8:32 a.m., May 18, 1980. C, $B$ - $B^{\prime}$ pre-March 1980. D, $B$ - $B^{\prime}$ at time of failure. E, $C$ - $C^{\prime}$ pre-March 1980 . F, $C$ - $C^{\prime}$ at time of failure. $\mathrm{G}, D-D^{\prime}$ pre-March 1980 . H, $D-D^{\prime}$ at time of failure. 

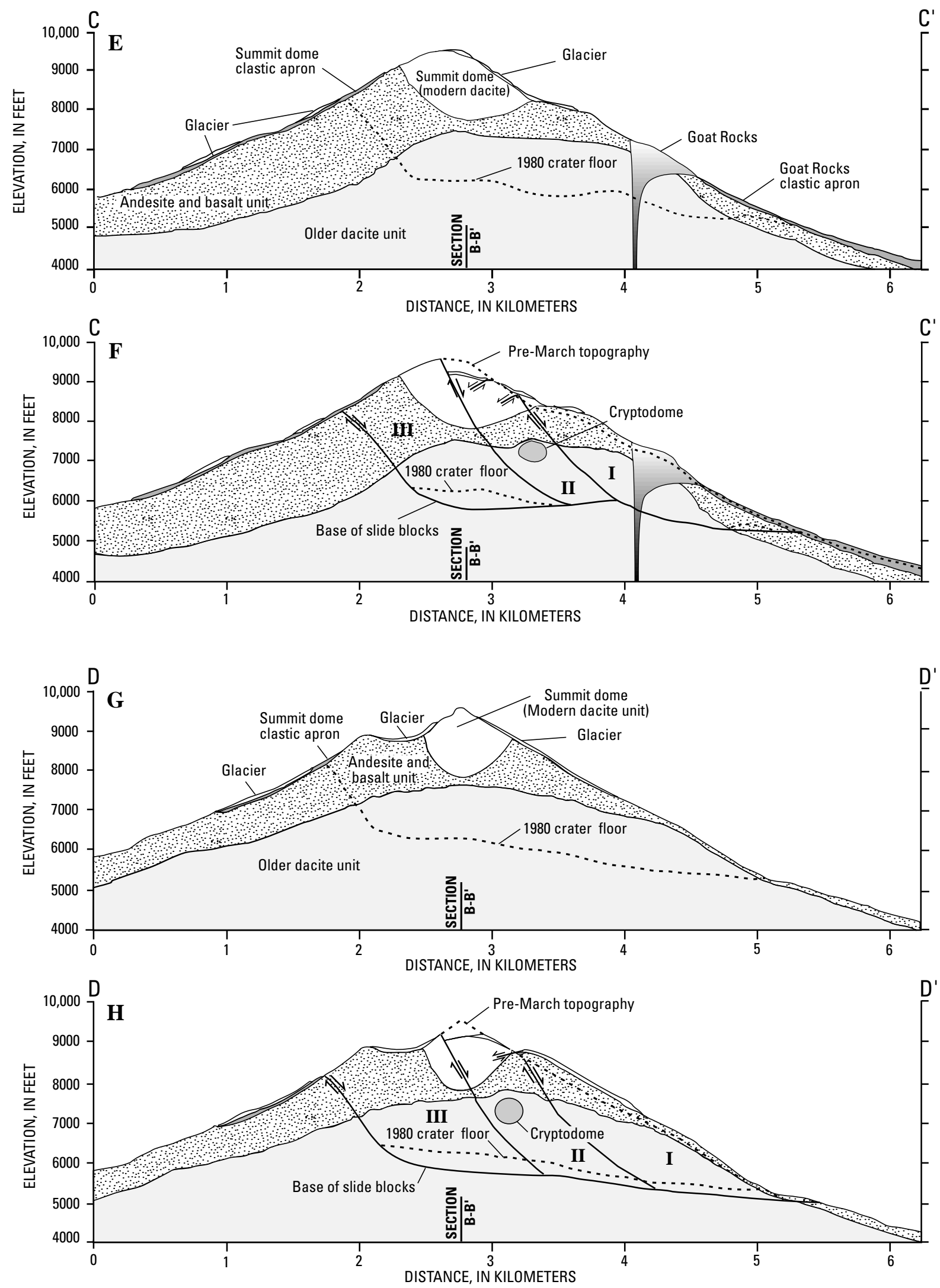

Figure 2. Cross sections of Mount St. Helens. I,II,III are slide blocks. Locations on figure 1. A, $A-A^{\prime}$ pre-March 1980 . B, $A-A^{\prime}$ at time of failure, 8:32 a.m., May 18, 1980. C, $B$ - $B$ ' pre-March 1980 . D, $B-B^{\prime}$ at time of failure. E, $C$ - $C$ ' pre-March 1980 . F, $C$ - $C$ ' at time of failure. $\mathrm{G}, D-D^{\prime}$ pre-March 1980 . $\mathrm{H}, D-D^{\prime}$ at time of failure--Continued. 


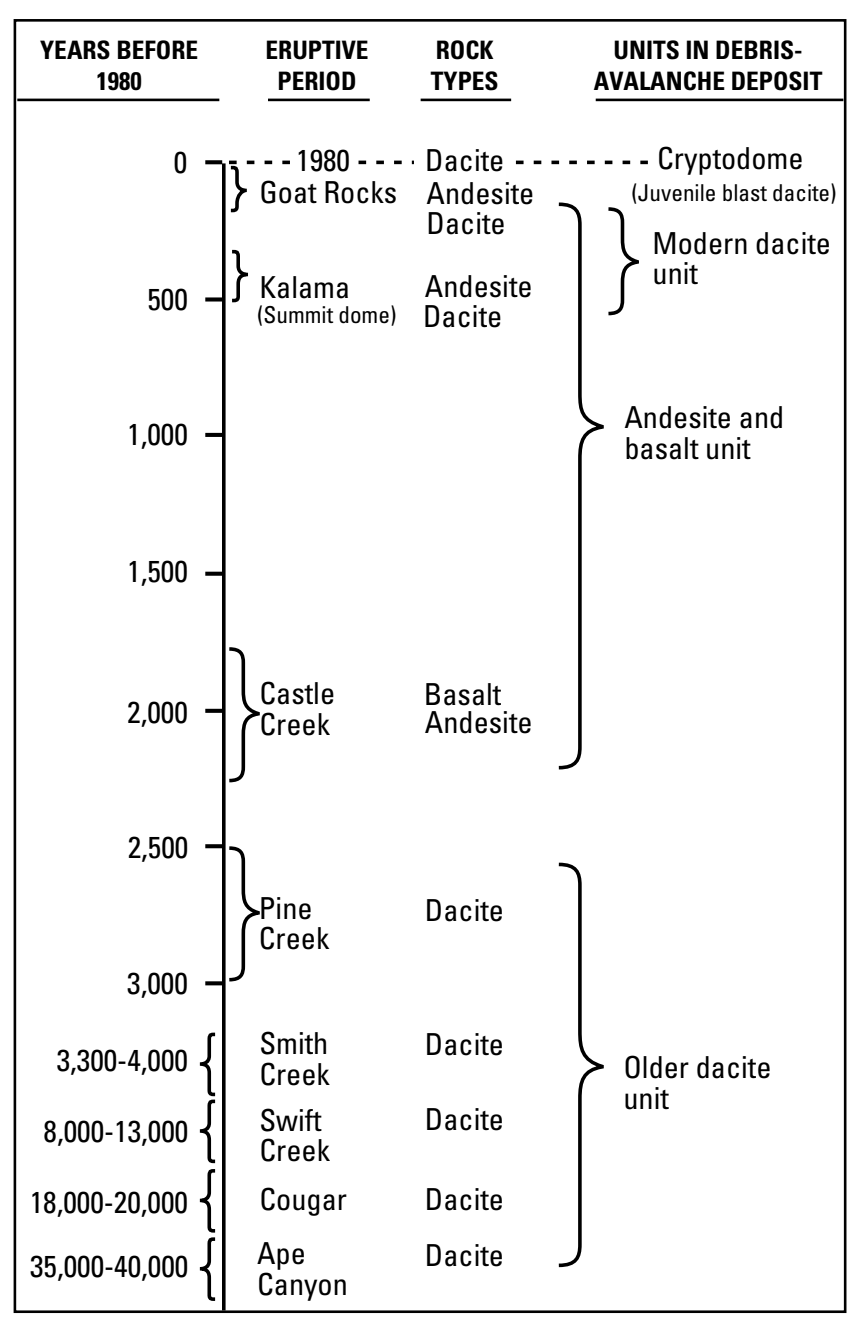

Figure 3. Eruptive periods of Mount St. Helens that produced rocks in debris avalanche, showing generalized units designated for this work. After Mullineaux and Crandell (1981).

\section{ANDESITE AND BASALT UNIT}

Dark-colored andesite and basalt in the crater, termed the "andesite and basalt unit", rest on the older dacite unit. These rocks are lava flows as well as lithic and scoriaceous tephra of andesitic and basaltic composition. They are correlated with the eruptive products of the Castle Creek and Kalama eruptive periods (fig. 3) that were mapped on and around the flanks of the pre-1980 mountain (C.A. Hopson, written commun., 1980) and dated at about 2,200 to 350 yr B.P. (Mullineaux and Crandell, 1981). However, some of these rocks in the crater are magnetized in a direction characteristic of rocks dated at 2,500-3,000 yrs (R.T. Holcomb, oral commun., 1981).

The andesites and basalts are distinct from the dacites in both color and mineralogy (figs. 5 and 6). They are generally black or dark gray but locally are altered to various shades of red. The andesites generally contain plagioclase phenocrysts, and they contain varying amounts of hypersthene and augite. Amphibole is scarce to absent; modal analyses of eight samples by Smith (1984) show 5 modal percent in one sample and trace amounts in two others. Olivine is uncommon (C.A. Hopson, written commun., 1984) in the true andesites (56 to 63 percent silica; Ewart, 1982) and generally occurs as resorbed microphenocrysts $<1 \mathrm{~mm}$ wide. The basalts and basaltic andesites $(<56$ percent silica) are characterized by olivine phenocrysts; point-counting of 10 samples shows 0.2 to 6.3 percent olivine (Smith, 1984). These rocks also generally contain plagioclase phenocrysts, and contain abundant augite. The basaltic andesites (53 to 56 percent silica) also have subordinate microphenocrystic hypersthene. The andesite and the basalt are both variably vesicular and locally are extremely scoriaceous.

\section{MODERN DACITE UNIT}

Dacite named here the "modern dacite unit" was present on the pre-eruption cone of Mount St. Helens. It consists of the Goat Rocks dome of the Goat Rocks eruptive period and the Summit dome of the Kalama eruptive period (fig. 3) as well as deposits of hot avalanches from these domes. The domes themselves were carried away in the rockslide-debris avalanche of May 18, but the hot avalanche deposits remain on the flanks. Summit dome was dated by Hoblitt and others (1980) to be approximately $350 \mathrm{yr}$ old. More recent tree-ring analyses suggest that dome emplacement began in A.D. 1647 and that the dome was intermittently active for about 100 years (Yamaguchi and Hoblitt, 1995). Goat Rocks was dated at approximately 123 to $180 \mathrm{yr}$ before 1980 (Hoblitt and others, 1980). Tree-ring evidence indicates the dome was active in A.D. 1842-1843 (Yamaguchi and Lawrence, 1993). The rocks are called "modern" dacite to distinguish them from the older dacite, which is older than 2,500 yr.

The modern dacite rocks of the Goat Rocks and Summit domes are chiefly augite-hornblende-hypersthene dacite (figs. $5 B$ and $6 B$ ). They are light gray when fresh and various shades of red and pink when altered. The dacite is nearly aphyric in hand specimen, but close examination reveals microphenocrysts of hornblende (or oxyhornblende), pyroxene, and plagioclase. The rock is distinguished from the older dacite by the size of the amphibole phenocrysts; the modern dacite phenocrysts are $<2 \mathrm{~mm}$ long, generally $<1 \mathrm{~mm}$ long (figs. 5 and 6), whereas the older dacite phenocrysts are $>2 \mathrm{~mm}$ long. Like the older dacite, the modern dacite also contains inclusions of primarily gabbroic composition (Heliker, 1984; 1995)

The rocks from the Goat Rocks and Summit domes are indistinguishable from each other in hand specimen 


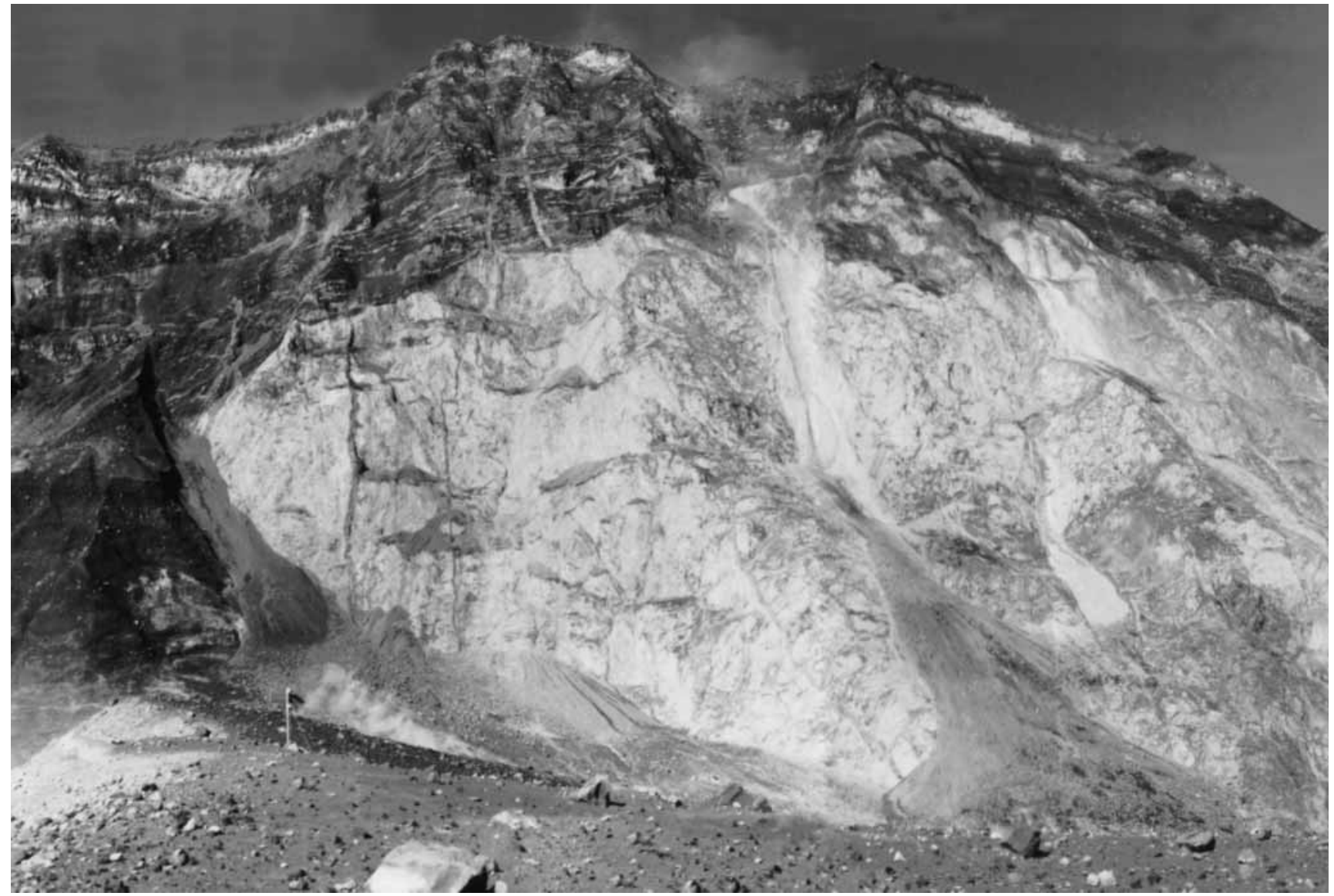

Figure 4. Photograph of west crater wall in summer 1980 showing light-colored older dacite unit overlain by dark-colored andesite-andbasalt unit.

and thin section (table 1). Moreover, available chemical analyses (Hoblitt and others, 1980; Smith and Leeman, 1987; C.A. Hopson, written commun., 1984) show considerable overlap in the chemical compositions.

A ternary diagram of the primary mafic minerals (fig. 8) suggests that Goat Rocks dome rocks generally have a higher ratio of orthopyroxene to hornblende+opaques than rocks from the Summit dome. However, the error inherent in the analysis (Galehouse, 1971) is greater than the difference between the rock types, and duplicate thin sections of the same rocks show a greater difference than between different rock types. Hornblende+opaques is used for a corner of the plot instead of hornblende, because in most thin sections from the highly altered domes, hornblende is thoroughly opacitized and is difficult to distinguish from opaque minerals. In some thin sections, the pyroxenes were also opacitized; these sections were not used in the analyses.

\section{CRYPTODOME}

The dacite magma body that rose up inside the mountain prior to May 18 is known as the cryptodome. The cryptodome was almost all molten material; on the exposed 1980-86 dome at Mount St. Helens, the outer margin cooled at a rate of $<5 \mathrm{~cm} /$ day (Dzurisin and others, 1990). Because the cryptodome was not exposed, its rate of cooling was probably much less, and the cryptodome was $<2$ months old on May 18 .

The rock that formed from this cryptodome was found throughout the blast deposit and parts of the debris-avalanche deposit. It is a distinctive gray, microvesicular to subpumiceous hypersthene-hornblende dacite (fig. 9C) (Hoblitt and others, 1981; Hoblitt and Harmon, 1993) called the juvenile "blast" dacite. Clasts of the dacite are characterized by prismatic jointing when struck with a hammer (fig. 9B), indicating that the rock was hot when the deposits were emplaced. Clasts commonly have one or more breadcrusted surfaces (fig. 9A). 

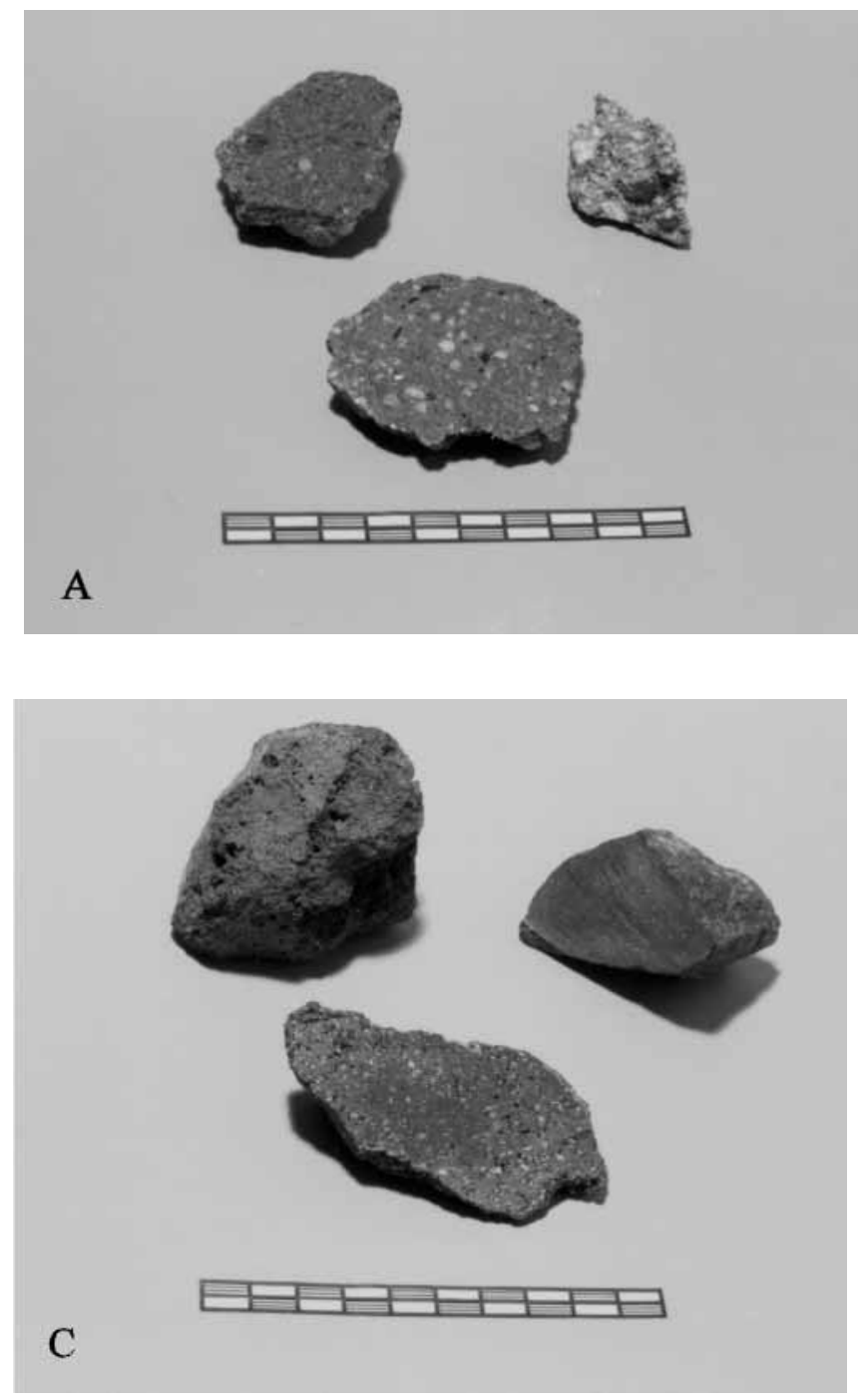

Figure 5. Photographs of hand samples of rock from the old mountain. Scale marked in 10-cm intervals. A, Older dacite. B, Modern dacite. C, Andesite. D, Basalt.

\section{PRE-ERUPTION STRUCTURE}

Cross sections of the volcano as it existed prior to the 1980 eruptions were constructed from geologic maps of the old volcano (C.A. Hopson, written commun., 1980) and measured sections of the 1980 crater (C.A. Hopson, written commun., 1984). Three cross sections trend approximately north-south through the axis of the crater, and one trends approximately east-west perpendicular to the axis (fig. 2). Preliminary cross sections were constructed by Voight and others $(1981,1983)$ and Moore and Albee (1981).

The structure of the part of the pre-1980 volcano that was removed in the rockslide was relatively simple (figs. $2 A, C, E, G)$. The older, pre-Castle Creek dacite made up the bulk of the mountain and was topped by the andesite and basalt lavas of the Castle Creek and Kalama eruptive
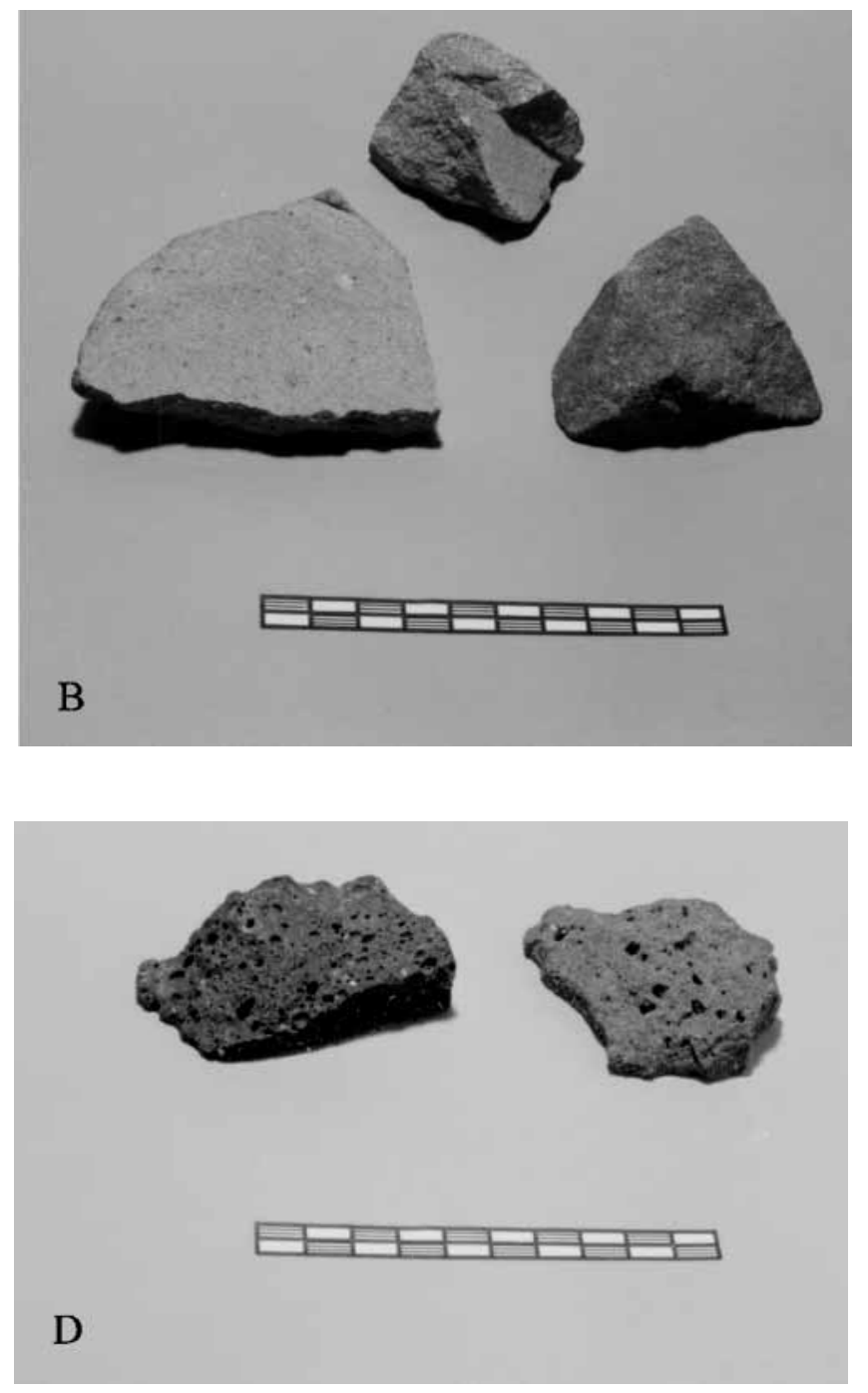

B periods. Feeders for the modern dacite domes (Goat Rocks dome and Summit domes) intruded through the older dacite and the andesite and basalt units. According to C.A. Hopson (Hopson and Melson, 1985), the Summit dome erupted into a summit crater at the beginning of the Kalama eruptive period. The volcano rests on well-lithified Tertiary bedrock (Evarts and others, 1987).

The intrusion that was unroofed in the May 18 lateral blast (the cryptodome) deformed the north side of the mountain (fig. 2B). Displacements of various points within a $1.5-$ by $2.0-\mathrm{km}$ area (called "the bulge"), which were measured by geodetic techniques, showed subhorizontal northerly movements of 1.5-2.5 m/day (Lipman and others, 1981). Comparison of topographic maps made from aerial photographs taken in 1979 and at various times during March-May 1980 (Voight and others, 1981; Jordan and Kieffer, 1981; Moore and Albee, 1981) 

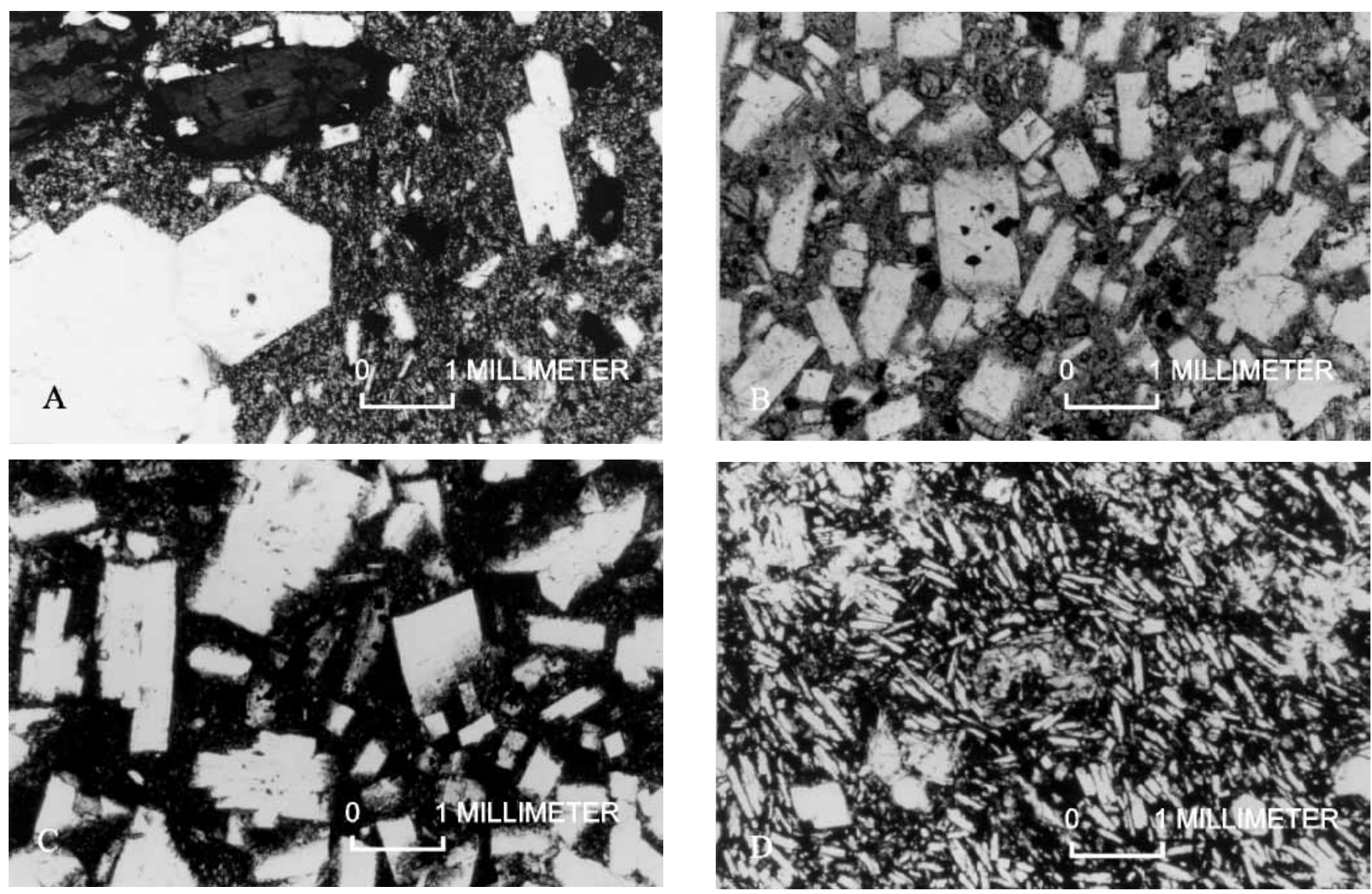

Figure 6. Thin sections of rock from the old mountain. A, Older dacite. B, Modern dacite. C, Andesite. D, Basalt.

shows dominantly northerly movements with local uplift of as much as $5.6 \mathrm{~m} /$ day. Moore and Albee (1981) modeled the geometry of the cryptodome as a bulbous mass slightly displaced to the north of the summit crater. Voight and others $(1981,1983)$ inferred a thick, sheetlike body bending in a northward direction within the andesite and basalt lavas.

The pre-May 18 intrusion is modeled here as intruding initially as a vertical magma body (figs. $2 B$ and $2 D$ ). The intrusion probably prepared the conduit for the 1980 explosive eruptions and 1980-86 dome. Its movement was constrained laterally by the feeder for the Summit dome and vertically by the Summit dome itself.

Seismic activity related to the volcano began about March 20, peaked on March 25 to 27 (the 27th was the day of the first phreatic eruption) and declined in subsequent weeks (Endo and others, 1981). This activity suggests that the cryptodome magma broke its way to its maximum altitude between March 20-27, and then magma continued to rise up the conduit and expanded the cryptodome to the north, causing lateral motion and some vertical uplift of the northern part of the cone. The northern migration of the area of maximum uplift after March
27 from its initial position just north of the summit graben (Moore and Albee, 1981; Lipman and others, 1981) is consistent with this idea.

The geometry and volume of the deformation and the total volume of juvenile material in the blast and debrisavalanche deposits constrains the geometry of the cryptodome. Because the similar chemistry of all the May 18 magmas suggests just one magma body (Lipman and others, 1981), the vent for the May 18 afternoon Plinian eruption is assumed to also be the conduit for the preMay 18 cryptodome below the crater floor. The cryptodome is assumed to be restricted from inflating significantly in a upward or southern direction by the Summit dome and its conduit. The lack of any deformation in an east-west direction at the latitude of the conduit (Lipman and others, 1981; Moore and Albee, 1981) suggests that the cryptodome did not inflate significantly in an east-west direction at the latitude of the conduit; however, east-west inflation north of the conduit perhaps accounts for some of the deformation that created the bulge.

The volume increase of the volcano from March to May 17, 1980, is calculated to have been $0.11-0.12 \mathrm{~km}^{3}$ 

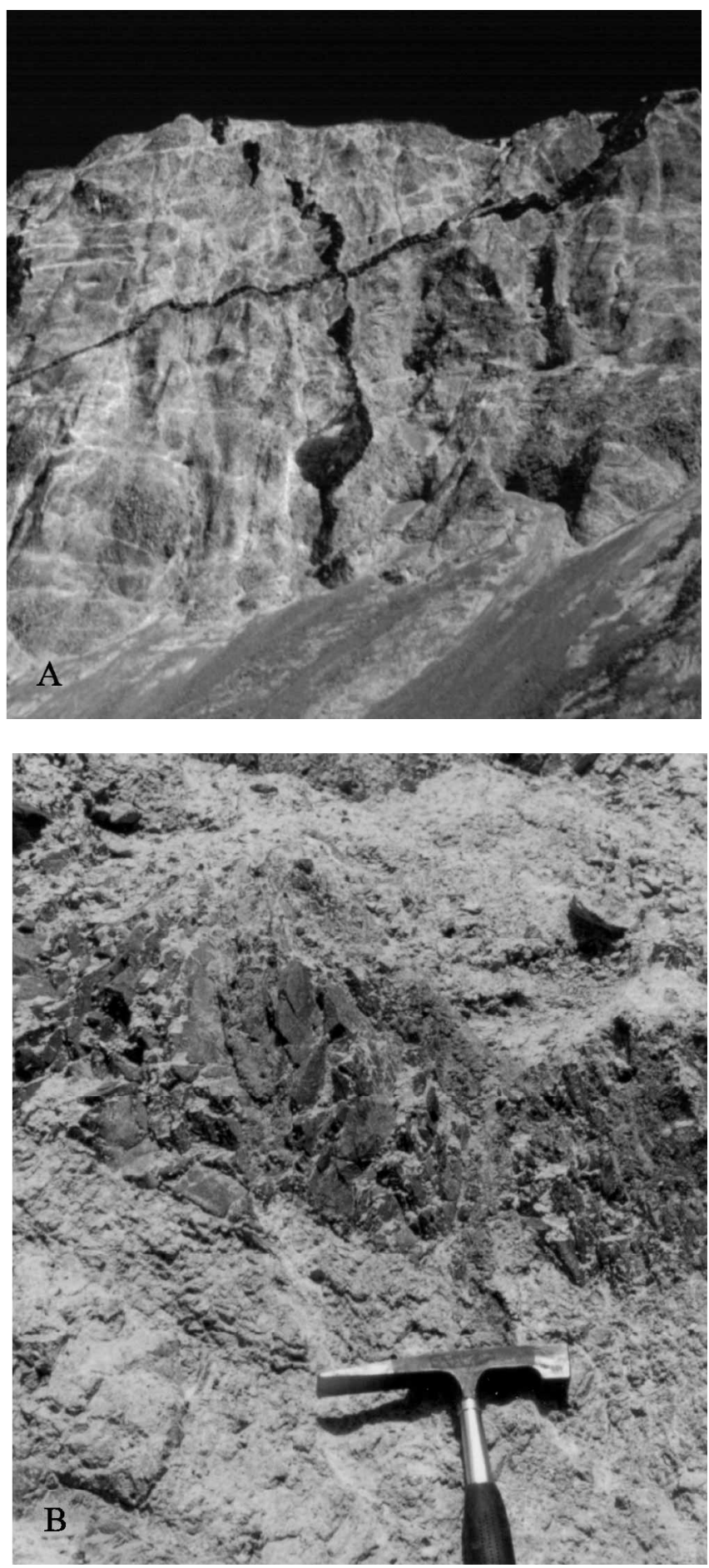

Figure 7. Dikes of andesite and basalt (lava flow feeders) in crater walls. A, View of east crater wall. Photograph by Lee Siebert. B, Closeup of dike showing fractures.

(Moore and Albee, 1981; Jordan and Kieffer, 1981). This is more than the $0.08 \mathrm{~km}^{3}$ volume of the cryptodome found within the deposits; about $0.05 \mathrm{~km}^{3}$ was found in the blast surge deposit (Moore and Sisson, 1981) and about $0.03 \mathrm{~km}^{3}$ in the debris-avalanche

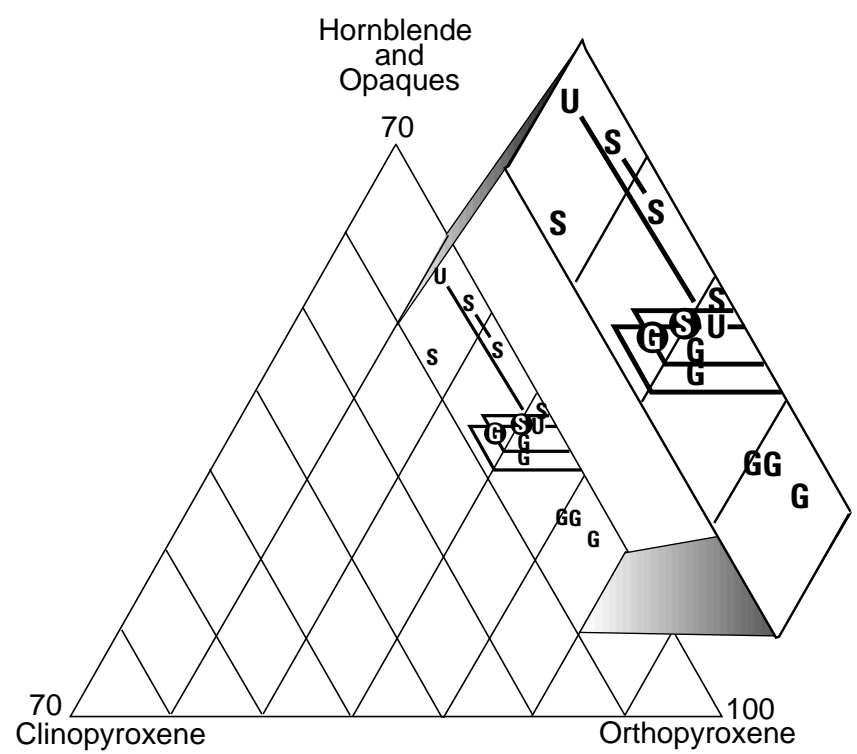

Figure 8. Ternary diagram of orthopyroxene, clinopyroxene, and hornblende+opaques for modern dacite dome rocks. S, summit dome; G, Goat Rocks dome; U, modern dacite of unknown origin from debris-avalanche deposit. Lines between points indicate duplicate thin sections of same rock. Boxes represent error at 95.4 percent confidence level (Kelley, 1971) for samples contained in circles.

deposit. The difference may be due in part to inaccuracies in the methods used to compute volumes, it may reflect volume increase owing to dilation of the material that made up the mountain or injection of fluids released from the magma (Voight and others, 1981), or the difference may result from cryptodome material exploding into ash too fine to be recognized as juvenile in the deposits.

Surface faulting was apparent on the mountain from March-May, 1980 (Voight and others, 1981; Moore and Albee, 1981; Krimmel and Post, 1981), and the surfaces of the glaciers on the north side of the mountain were highly fractured. Some of the surface fractures, especially those associated with North Point and New North Point, likely extended to depth to take up tens of meters of displacement associated with the cryptodome emplacement and northward expansion (fig. 2B), but much of the deformation associated with the cryptodome may have been taken up as displacement along smaller faults that were not expressed on the surface. Because there is no information on the nature and geometry of these hypothetical faults, they are not shown on figure 2.

\section{GEOLOGY OF THE SLIDE BLOCKS}

The initial movement of the rockslide-debris avalanche is modeled as three slide blocks (fig. 2). The slide blocks represent a series of retrogressive slope failures. 
Table 1. Modal analyses of modern dacite rocks from Mount St. Helens

[All samples from C.A. Hopson unless noted. plag, plagioclase; hbl, hornblende; opx, orthopyroxene; cpx, clinopyroxene; opaque, opaque minerals; xeno, xenolith; grdms, groundmass; vesicle, vesicles]

\begin{tabular}{|c|c|c|c|c|c|c|c|c|c|}
\hline Rock & plag & hbl & opx & $\operatorname{cpx}$ & opaque & xeno & grdms & vesicle & Total \\
\hline \multicolumn{10}{|c|}{ Goat Rocks } \\
\hline $259-1$ & 416 & 3 & 87 & 5 & 26 & 36 & 413 & 19 & 1003 \\
\hline $442-1$ & 399 & 7 & 65 & 5 & 16 & 8 & 446 & 53 & 1000 \\
\hline $28-1$ & 435 & 9 & 52 & 6 & 22 & 64 & 430 & 23 & 1040 \\
\hline $1318-6$ & 373 & 5 & 76 & 4 & 17 & 52 & 387 & 87 & 1001 \\
\hline $8117 \# 1^{1}$ & 311 & 4 & 72 & 7 & 34 & 15 & 471 & 47 & 1001 \\
\hline $8171 \# 2^{1}$ & 333 & 13 & 67 & 5 & 24 & 27 & 465 & 57 & 1000 \\
\hline \multicolumn{10}{|c|}{ Summit dome } \\
\hline 394-1\#1 & 387 & 11 & 48 & 2 & 29 & 4 & 466 & 63 & 1010 \\
\hline $394-1 \# 2$ & 416 & 11 & 33 & 1 & 17 & 3 & 482 & 59 & 1020 \\
\hline $355-2$ & 414 & 6 & 70 & 5 & 37 & 1 & 415 & 53 & 1001 \\
\hline $151-1 \# 1$ & 423 & 18 & 46 & 2 & 33 & 2 & 472 & 25 & 1017 \\
\hline $151-1 \# 2$ & 351 & 15 & 67 & 1 & 27 & 50 & 536 & 21 & 1022 \\
\hline $1337-3$ & 470 & 14 & 37 & 8 & 24 & 25 & 410 & 16 & 1004 \\
\hline \multicolumn{10}{|c|}{ Modern dacite from debris avalanche (unkown dome) } \\
\hline $913 \mathrm{G} \# 1^{1}$ & 385 & 5 & 24 & 2 & 27 & 26 & 549 & 1 & 1000 \\
\hline $913 \mathrm{G} \# 2^{1}$ & 400 & 3 & 50 & 3 & 27 & 25 & 503 & 3 & 1011 \\
\hline
\end{tabular}

Slide blocks I and II were individual discrete failures, but the area outlined as slide block III probably generated many discrete, successive failures that mixed with juvenile (cryptodome) and nonjuvenile material generated from the continuing blast explosions (Voight and others, 1983). The events associated with the movement of the slide blocks are discussed in greater detail in other parts of this report.

Various data are used to determine boundaries of the slide blocks. The crater floor shown in figure 2 is taken from a topographic map (fig. 1) made from aerial photographs flown in summer 1980. However, the crater floor does not represent the base of the slide blocks; the base is probably represented by the strong seismic velocity discontinuity that is $60-150 \mathrm{~m}$ below the crater floor along the axis of the crater floor from the dome to the north end of the crater (Malone and Pavlis, 1983). This discontinuity seems to coincide with the intersection of the curving slopes of the crater walls projected underneath the talus and the crater floor. The curviplanar crater walls at the north end of the crater are assumed to represent lateral boundaries of slide block I; the base of slide block I on the cross section was obtained by extending the contours of the spoon-shaped walls across the axis of the crater. The base of slide block II is assumed to be roughly paral- lel with the base of slide block I. The tops of the breakaway scarps of slide blocks I and II are seen on the photographs of Keith and Dorothy Stoffel (Stoffel and Stoffel, 1980; Foxworthy and Hill, 1982) and Gary Rosenquist (Voight, 1981) and are simply transferred to the cross section by noting their location relative to various points on the mountain as in Voight and others (1981).

About $0.2 \mathrm{~km}^{3}$ of unconsolidated material rests on the base of the slide blocks in the crater. Nearly all the material is interpreted to be part of the "proximal unit" of the debris-avalanche deposit (see "Geologic Maps of the Deposit") because of its hummocky surface as well as exposures and density characteristics typical of the debris-avalanche deposit. The top few meters of the crater-filling material are pumiceous pyroclastic-flow and tephra deposits from the later events of May 18.

The volumes of the three slide blocks and the volumes of the different geologic units in each of the three slide blocks (table 2) were computed using the three north-south-trending cross sections (figs. $2 B, F$, and $H$ ). Because of the geometry of the crater, the structure of the mountain is extremely difficult to interpret outside the area bounded by the cross sections. The cross sections enclose 75 percent of the volume of the crater. Because 

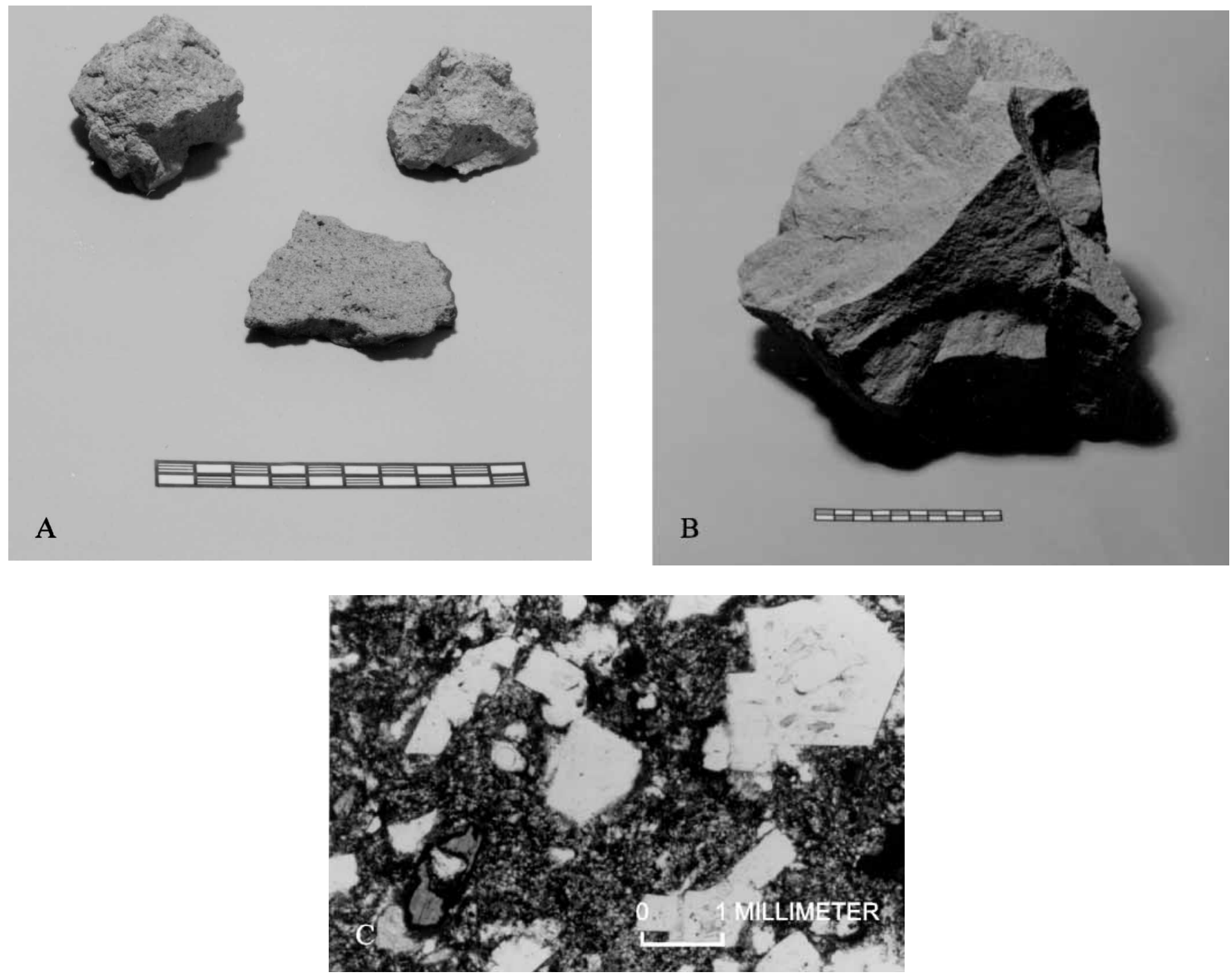

Figure 9. Photographs of juvenile blast dacite. A, Breadcrusted surface, indicating hot emplacement. Scale marked at 10-cm intervals. B, Prismatic jointing, indicating hot emplacement. Scale marked at $10-\mathrm{cm}$ intervals. C, Thin section.

the cross sections are similar except for the Goat Rocks dome and the cryptodome, Goat Rocks dome and the cryptodome were removed from the cross sections, and then the relative volumes of each slide block and geologic unit were assumed to be the mean of the relative areas in each of the three north-south cross sections. The volume outside the cross sections may be expected to increase the percentage of the andesite and basalt unit relative to the older dacite unit and decrease the amount of the modern dacite unit relative to the other units, but probably by an amount small enough to not significantly affect the results in table 2. The volume of the Goat Rocks dome, which was estimated to be $0.03 \mathrm{~km}^{3}$ (on the basis of the area of the dome as shown on the geologic map and the structure as shown in the cross sections), is contained entirely within slide block II; the volume of the cryptodome, which is assumed to be $0.12 \mathrm{~km}^{3}$ (Moore and Albee, 1981), is assumed to be about 50 percent within slide block II and 50 percent within slide block III, on the basis of the cross sections.

\section{GEOMETRY OF THE DEPOSIT}

The debris-avalanche deposit covers about $64 \mathrm{~km}^{2}$, including the material within Spirit Lake. Nearly all the deposit is contained in a contiguous mass measuring about $26 \mathrm{~km}$ from the east to west ends along its axis, and from 0.5 to $5 \mathrm{~km}$ wide measured perpendicular to the axis. The longest travel path of the debris avalanche was 
Table 2. Slide blocks in each cross section and geologic units in each slide block

[Based on analysis of fig. 2; methodology discussed in text. Total volume of slide blocks includes source area for debris avalanche (including proximal units), blast, and lithic airfall deposits]

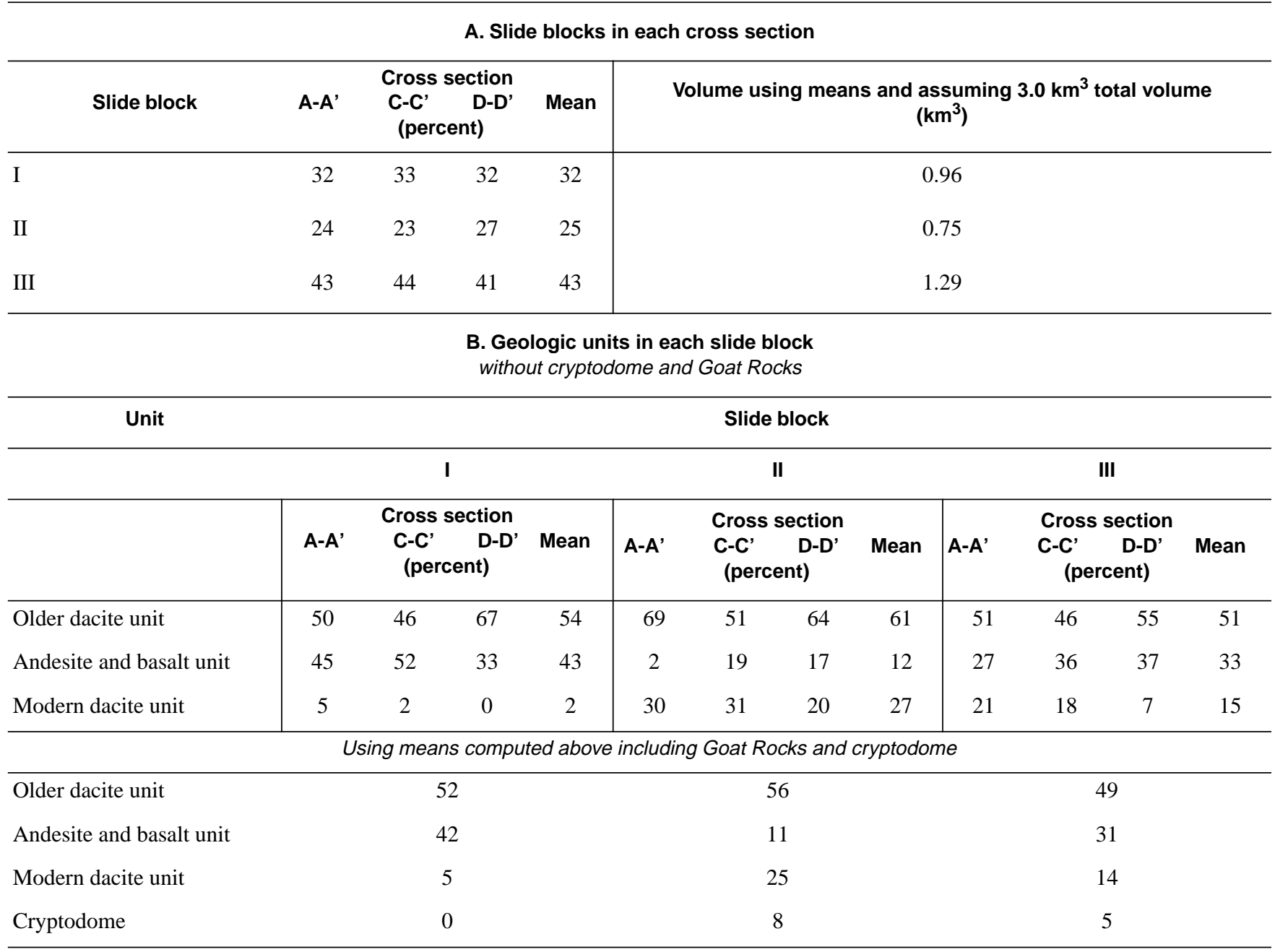

$29 \mathrm{~km}$, measured from the source of the material (taken as the site of the 1980-85 lava dome) to the distal (west) end (along cross section $H-H^{\prime \prime}$ pl. 5).

\section{VOLUME AND THICKNESS}

An isopach map of the material in the North Fork Toutle River valley and in the valley of South Coldwater Creek (pl. 1) was constructed by K.A. Cameron (written commun., 1982) using 1:24,000-scale topographic maps based on summer 1980 aerial photographs as well as 1954 1:62,500-scale maps. Nearly all the material represented by this isopach map is the debris-avalanche deposit. However, lahar deposits of May 18, blast deposits covering the avalanche, and deposits of the 1980 pyroclastic flows just north of the mountain also fill the valley and are included on the isopach map. The lahar deposits and the blast deposits are both $<10 \mathrm{~m}$ thick on top of the avalanche deposit (Janda and others, 1981; Fisher and others, 1987); this thickness is within the range of error of the maps. The pyroclastic flow deposits are $>40 \mathrm{~m}$ thick in some areas (Glicken and others, 1989; Criswell, 1984).

The volume of the material on the isopach map was computed to be $2.3 \mathrm{~km}^{3}$ (K.A. Cameron, written commun., 1984). Adding the $0.43 \mathrm{~km}^{3}$ of material in Spirit Lake (Meyer and Carpenter, 1982) and subtracting the $0.25 \mathrm{~km}^{3}$ volume of the 1980 pyroclastic-flow deposit (C.W. Criswell, written commun., 1985) gives a net volume of $2.5 \mathrm{~km}^{3}$ for the debris-avalanche deposit. This value is based on more accurate data than the preliminary estimate of $2.8 \mathrm{~km}^{3}$ (Voight and others, 1981, 1983). 
Neither calculation includes the approximately $0.2 \mathrm{~km}^{3}$ of the crater-filling proximal unit.

The thickness of the debris-avalanche deposit is in part a function of the underlying topography and the configuration of the valley walls (shown on pls. 3, 4, and 5). The deposit is thickest and the surface has the greatest relief and the largest hummocks in the channel of the preeruption North Fork Toutle River, but the deposit is much thinner and the relief more subdued on the terraces of the North Fork.

The debris-avalanche deposit thins significantly just downstream from two major constrictions in the North Fork Toutle River valley (pl. 1). The first constriction, just west of the junction of Maratta Creek and the North Fork Toutle River, coincides with the contact between the debris-avalanche deposit composed entirely of block facies and the mixed block and matrix facies of the western part of the avalanche deposit (pl. 4). West of this constriction, the deposit thins, then it thickens again (pl. 1) at the constriction just south of Elk Rock. As the valley widens again just west of this constriction, there is a second break-in-slope. The deposit is $<30 \mathrm{~m}$ thick west of this break-in-slope.

\section{MORPHOLOGY OF HUMMOCKS}

Hummocks are the most characteristic morphologic feature of the debris avalanche deposit. Various parameters of hummocks were measured on 1:24,000-scale USGS topographic maps (with a 40-ft [12.2 m] contour interval; base map of pl. 3) made from summer 1980 aerial photographs. The measurements quantify the characterization of the morphology and provide clues regarding the emplacement of the deposit.

For the purpose of the topographic map analysis, a hummock is considered to be represented by one or more closed contours (fig. 10). The minimum height of a hummock is measured as:

(number of closed contours - 1) x $40 \mathrm{ft}$ [12.2 m].

The maximum height of a hummock is measured as:

(number of contours to base of slope - 1) x $40 \mathrm{ft}$ [12.2 m].

The volume of each hummock is calculated by multiplying the area of each closed contour by the contour interval (40 ft) and adding the volume increments together.

The 40-ft contour interval limits the accuracy of the measurements. The contour interval results in a total

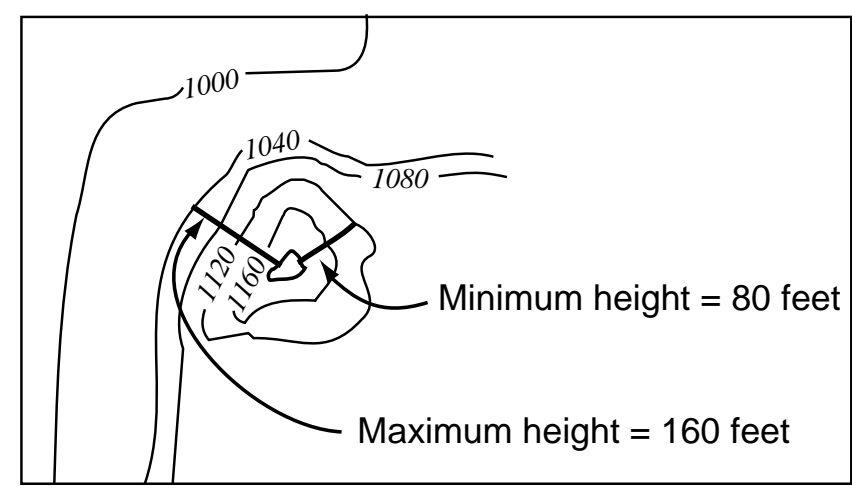

Figure 10. Example of a hummock on a topographic map, showing maximum and minimum measured heights.

error of $\pm 20 \mathrm{ft}$ [6.1 m] for the measurements of hummock heights. The error for the hummock volume is:

$\pm 20 \mathrm{ft}[6.1 \mathrm{~m}] \times$ area of the largest closed contour.

Six hundred seventy-five hummocks were identified on the 1:24,000-scale topographic maps. The hummocks of the proximal unit on the north flank of the mountain and in the crater were not used in this analysis. The maximum and minimum heights, length, width, and orientation of the long axis for each hummock were measured and the volume of each hummock was calculated.

A number of different hummocks can be classified as "the largest" hummock. The most voluminous hummock is $2.1 \times 10^{6} \mathrm{~m}^{3}$, and it is $15 \mathrm{~km}$ from its source at Mount St. Helens. The highest measured minimum height is $37 \mathrm{~m}$ for a hummock $11 \mathrm{~km}$ from the source. The highest maximum height is $73 \mathrm{~m}$ for the same hummock. The longest hummock, $600 \mathrm{~m}$ in length, is $15 \mathrm{~km}$ from the source.

All the parameters except long-axis orientation were plotted against distance from source (figs. 11A-E). It is apparent that there are fewer of the larger hummocks toward the distal end of the deposit.

There are two maxima on the plot of hummock length versus distance from source (fig. 11A). The largest hummocks are at 10 to $16 \mathrm{~km}$, and a secondary maximum is at 19 to $22 \mathrm{~km}$. These two maxima are also expressed on the plots of hummock maximum height (fig. 11D) and hummock volume (fig. 11C).

All the plots show a "background" of small hummocks that extend throughout the length of the debrisavalanche deposit. These hummocks have volumes $<2 \times 10^{5} \mathrm{~m}^{3}$, lengths $<80 \mathrm{~m}$, widths $<50 \mathrm{~m}$, maximum heights $<15 \mathrm{~m}$, and minimum heights $<15 \mathrm{~m}$. The background makes up more than 50 percent of the total number of hummocks, and more than 90 percent of the hummocks beyond $24 \mathrm{~km}$. 

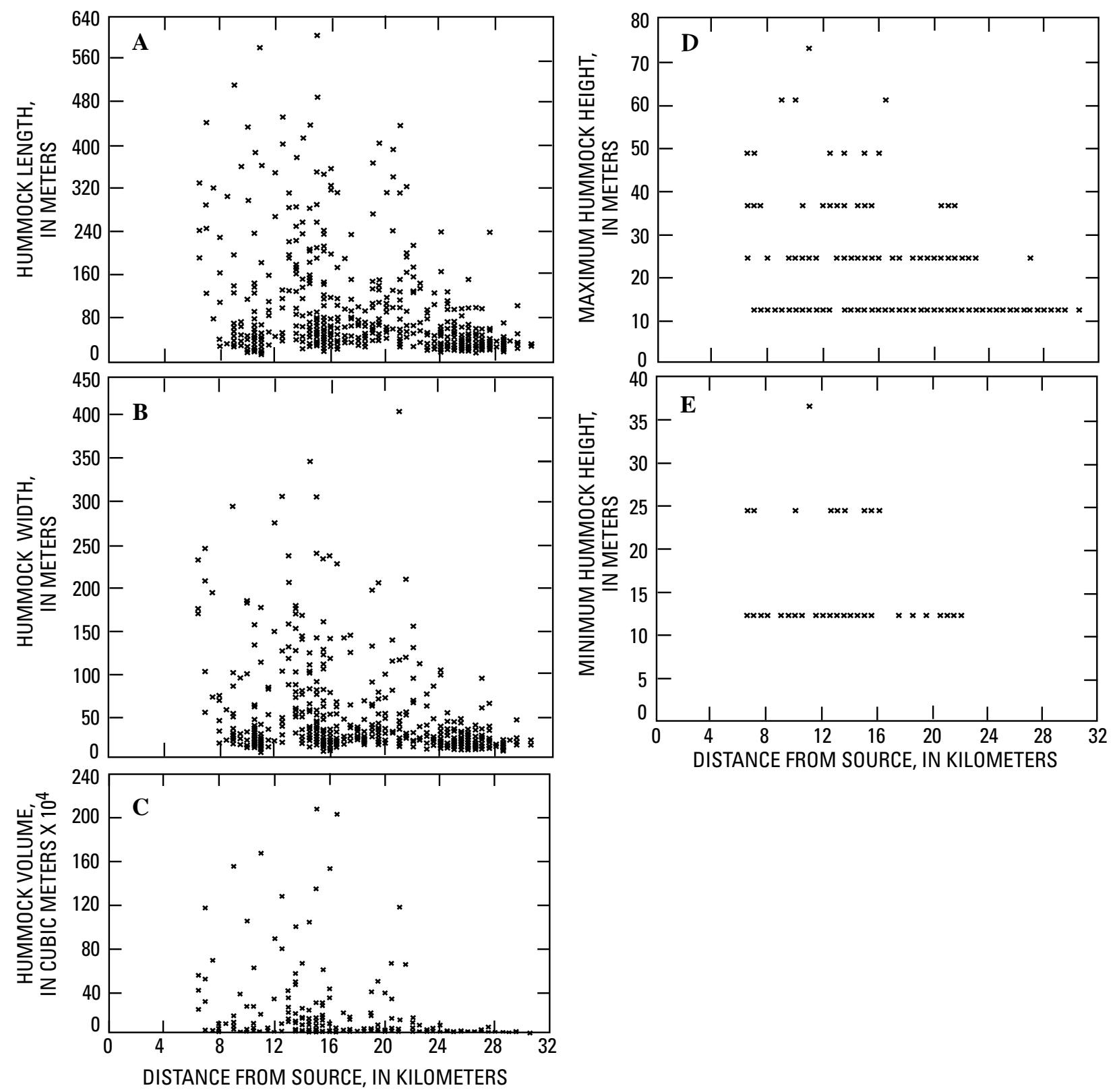

Figure 11. Hummock parameters versus distance from source. A, Length versus distance from source. B, Width versus distance from source. C, Volume versus distance from source. D, Maximum height versus distance from source. E, Minimum height versus distance from source.

\section{ORIENTATION OF ELONGATE HUMMOCKS}

The long axes of elongate hummocks of the debrisavalanche deposit are plotted on plate 2. Plate 2 is constructed from a composite of 1:24,000-scale topographic maps (the base map for pl. 3), so it does not show the smallest hummocks. Rose diagrams showing the orientations of the long axes are plotted adjacent to the outlined parts of the debris-avalanche deposit.

The long-axis orientations of the hummocks generally are aligned approximately with the direction of flow of the avalanche (areas B, D, F, G, and H, pl. 2). How- ever, at the distal end of the debris-avalanche deposit (area A) and at the constrictions in the valley of the North Fork Toutle River (areas C and E), where much of the avalanche material stopped, the hummocks have relatively random orientations.

\section{HUMMOCK TYPES}

The hummocks of the debris-avalanche deposit are divided into three different types based on the relation of block facies to matrix facies (fig. 12). Block facies con- 


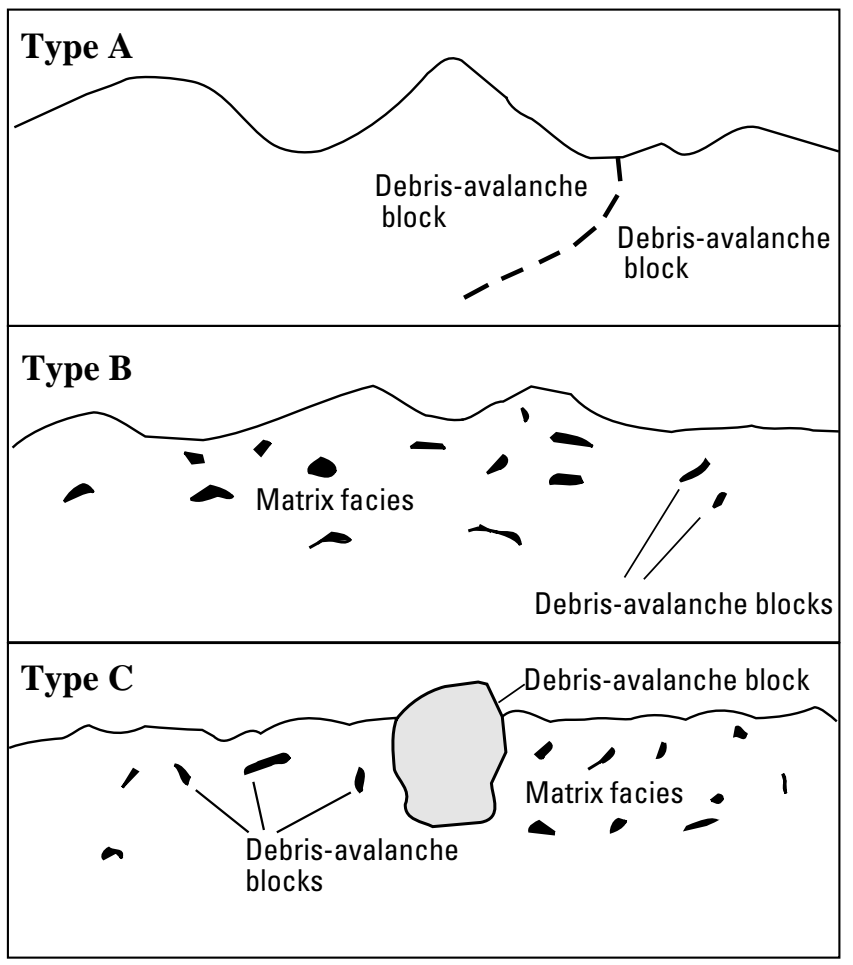

Figure 12. Hummock types. Type A, block facies with no matrix facies. Type B, predominantly matrix facies, debris-avalanche blocks scattered throughout. Type $\mathrm{C}$, debris-avalanche block suspended in matrix facies; matrix facies probably carried debris-avalanche block.

sist of debris-avalanche blocks, unconsolidated or poorly consolidated pieces of the old mountain transported relatively intact. Matrix facies is an unconsolidated mixture of all rock types from the old mountain and the juvenile dacite; it contains clasts that range in size from microns to meters. Block and matrix facies are discussed in detail in "Texture of the Deposit".

Type A, block facies hummocks with no matrix facies. One or more debris-avalanche blocks extend from hummock to hummock (figs. 12 and 13A). There is no matrix facies in the hummocks or in the interhummock areas. Most of the hummocks of the eastern part of the debris-avalanche deposit are type A hummocks.

Type B, predominantly matrix facies hummocks. These hummocks are made up almost entirely of matrix facies (figs. 12 and 13B). Vertical exposures show that there is no debris-avalanche block at the cores of the hummocks, but there may be small debris-avalanche blocks scattered throughout the hummocks (fig. 12). These hummocks are generally much smaller than type A hummocks.

Type C, hummocks made of debris-avalanche blocks resting in matrix facies. These hummocks are made entirely of large debris-avalanche blocks of the block facies that rest in and likely were carried by the
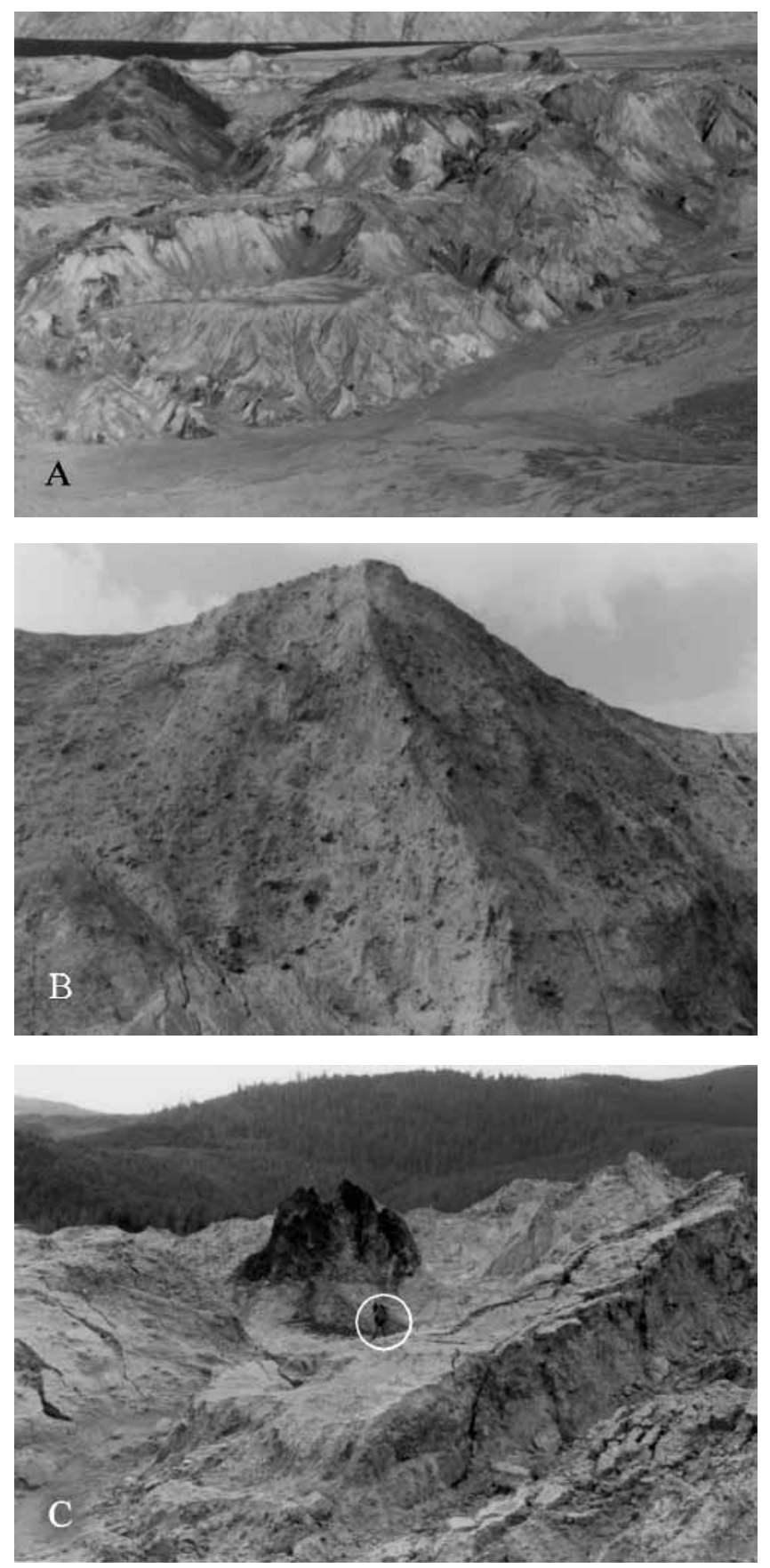

Figure 13. Photographs of types of hummocks. A, Type A. Oblique aerial photograph looking east toward Spirit Lake. View about $500 \mathrm{~m}$ wide. Hummocks are horsts in single debris-avalanche block. Contact of dark andesite and basalt unit overlying light-colored, older dacite unit preserved intact from old mountain. B, Type B. Hummock composed primarily of matrix facies. Small debris- avalanche blocks are scattered throughout the hummock. C, Type C. Debris-avalanche block suspended in matrix facies. Note person for scale (circle).

matrix facies (figs. 12 and 13C). Type $\mathrm{C}$ hummocks occur only in the western part of the deposit. At other volcanic debris-avalanche deposits (for example, the deposit north of Mount Shasta, Calif.; Crandell and oth- 
ers, 1984), most of the hummocks are interpreted to be type $\mathrm{C}$ hummocks, but type $\mathrm{C}$ hummocks are very rare in the Mount St. Helens debris-avalanche deposit.

\section{FORMATION OF THE HUMMOCKS}

Three mechanisms caused the formation of the hummocks. Many hummocks probably formed from a combination of two or more of the proposed mechanisms.

Mechanism 1. Some hummocks represent the horsts of a simple horst and graben system (Voight and others, 1981, 1983). This is most evident in type A hummocks, where contacts from the old mountain were preserved intact during transport (fig. 13A) and the contacts are faulted down between the hummocks. Such features are most common just west of Spirit Lake, but they also occur in the canyon of the North Fork Toutle River near Coldwater Lake. Slickensides resulting from normal faulting were visible on some hummocks in the first weeks after the eruption (Voight and others, 1981).

Some hummocks with long-axis orientations parallel to flow direction could be horsts resulting from lateral spreading of the debris downstream of a constriction. The horsts would be part of a system of horsts and grabens aligned parallel with the direction of flow.

Mechanism 2. Some hummocks probably represent the surface topography of debris-avalanche blocks (pieces of the old mountain). This is illustrated by hummocks that show strata parallel to the surface of the hummock, not faulted down between hummocks (fig. 14). In the eastern part of the avalanche deposit, these hummocks are type A hummocks, where debris-avalanche blocks abut debris-avalanche blocks. In the eastern part of area $\mathrm{G}$, plate 2, the orientations of the long axes of several hummocks are transverse to the direction of flow of the debris avalanche, and the hummocks are anomalously large, suggesting that they were formed by mechanism 2 . In the western part of the deposit, these hummocks are type $\mathrm{C}$ hummocks, where debris-avalanche blocks are suspended in matrix facies and a hummock is made of only one debris-avalanche block.

Mechanism 3. Some hummocks (both type A and type B) formed as material was decelerated by basal or lateral shear. There are two classes of hummocks formed by this mechanism.

3A. Hummocks with long axes parallel to flow. Many hummocks with long axes parallel to the direction of flow probably formed as material decelerated by basal shear was sculpted by material moving at a higher speed. Hummocks adjacent to valley walls can be considered to be levees, which are common along the margins of the

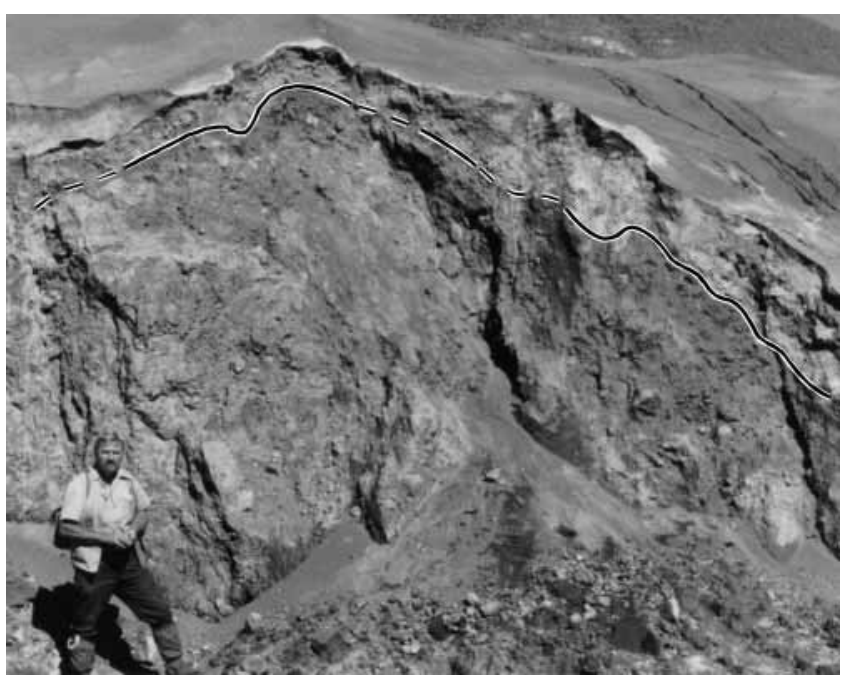

Figure 14. Hummock with preserved contact paralleling surface. Surface of hummock probably represents original topography of debris-avalanche block.

deposit (see "Geologic Maps of the Deposit"). The levees are interpreted to represent "dead regions" (Johnson and Rodine, 1984) at the flow margins of a Coulomb-viscous material. The model predicts that material in the center of the channel moves as a rigid plug, bounded by zones of laminar flow where velocity varies from a maximum at the boundary with the plug to zero near the walls of the channel. "Dead regions" occur along margins of the channel; material is immobilized because the shear generated by the movement of flowing debris cannot overcome the strength of the material.

Some elongate hummocks oriented parallel to the direction of movement but not adjacent to valley walls could result from a similar process. However, unlike the ideal materials considered by Johnson and Rodine (1984), which have strength parameters uniformly distributed throughout the moving mass, the debris avalanche consists of a combination of many different materials and was characterized by strength inhomogeneity. Parts of the avalanche subjected to high basal shear resistance slowed; adjacent parts of the material characterized by less strength flowed past, sculpting the slower moving material into elongate hummocks. Evidence for this mechanism is that the most prominent elongate hummocks are near Castle Lake (pl. 2), one of the thinnest areas of the debris-avalanche deposit (pl. 1). In thin parts of the avalanche, basal shear would be expected to be important.

3B. Hummocks with randomly oriented long axes. Near the terminus of the deposit, as well as just upstream from constrictions in the valley of the North Fork Toutle River, the debris avalanche was also decelerated by basal 
shear and piled up. In these areas, the hummocks are either not elongate or are elongate with randomly oriented long axes (areas A, C, and E, pl. 2). The woodbearing hummocks of the distal $4 \mathrm{~km}$ of the debris-avalanche deposit (the distal material) display relations that are suggestive of the mechanism of hummock formation in these areas (fig. 15). In the distal area, tree orientation is random in the hummocks, but between the hummocks, the trees are oriented parallel to the direction of flow. When the movement was relatively steady, trees splintered and movement continued; when the material decelerated, trees tangled together and had too much strength to be torn apart. Alternatively, tangling of trees may have caused the deceleration. Trees that did not get tangled flowed around the hummocks for a short distance. Because this part of the avalanche mass was decelerating, the difference in velocity between the hummocks and the interhummock areas was small, and the interhummock material moved only a few meters past the hummocks, so hummocks were not sculpted into longitudinally oriented forms.

\section{INTERPRETATION OF SIZE DATA}

Figure 11 shows that the number of large hummocks decreases with distance from source. This is interpreted to reflect decreasing debris-avalanche block size as well as the increasing amount of matrix-facies material with distance from source. Type A hummocks are generally made up of one or a few debris-avalanche blocks and are generally formed by mechanisms 1 and 3 . As the debrisavalanche blocks broke up during transport, smaller hummocks formed from the smaller debris-avalanche blocks. Hummocks consisting primarily of matrix facies material (type B hummocks) are present only in the western part of the avalanche deposit--these hummocks are generally much smaller than the type A hummocks that characterize the eastern part of the deposit. Type $\mathrm{C}$ hummocks are rare and have little effect on the plots.

At 12 to $17 \mathrm{~km}$ from source, a few anomalously large hummocks disrupt the general decreasing trends on the plots in figure 11. The orientations of these hummocks (eastern part of area G, pl. 2) and their anomalous size suggest that they were formed by mechanism 2 and thus represent the original size and shape of pieces of the old mountain that were relatively unaffected by processes during debris avalanche flow.

The secondary maximum on figures $11 A, 11 B$, and $11 C$ at 19 to $22 \mathrm{~km}$ probably results from a constriction in the valley of the North Fork Toutle River. The constriction resulted in the deceleration and piling up of the flowing debris, promoting formation of type B hummocks by mechanism $3 B$.

The size parameters (fig. 11) show evidence of a "background" of small hummocks throughout the deposit. The smaller hummocks are far more common than larger hummocks. This suggests that in all parts of the debris avalanche, small volumes of homogeneous material (debris-avalanche blocks or aggregates of blocks with similar properties) are more common than larger debrisavalanche blocks.

\section{GEOLOGIC MAPS OF THE DEPOSIT GENERAL STATEMENT}

Two kinds of geologic maps of the debris avalanche were compiled for this report. Units in the first kind (pl. 3) are defined primarily on the basis of morphology. Plate 3 is a more detailed version of the map published by Voight and others (1981) and Lipman (1981). The base for the map is a mosaic of preliminary U.S. Geological Survey topographic quadrangles at a scale of 1:24,000. The second kind (pl. 4) is a detailed geologic map of lithologic units in the debris-avalanche deposit. Seven transverse cross sections and one longitudinal cross section (pl. 5) were also constructed from the lithologic map. Mapping was done during the summers of 1981, 1982, and 1983 using air photographs at a scale of 1:10,000. The data were transferred using a stereo zoom transfer scope to a base map at a scale of 1:12,000, which was reduced from 1:4,800-scale topographic maps produced by Tallamy, Van Kuren, Gertis, and Associates (TVGT) under contract with U.S. Geological Survey. Both base maps were constructed from summer 1980 photography, and so they show the morphology of the debris-avalanche deposit with little erosional modification.

An important purpose of the geologic maps is to provide a basis for improved understanding of the processes of flow and emplacement of the debris avalanche. Examination of the patterns of units on these two kinds of maps allows interpretation of the various phases of flow of the debris avalanche and leads to interpretations of relative velocities of various parts of the once-moving mass. The lithologic map of the debris-avalanche deposit allows interpretation of the travel paths of parts of the material from their original positions on the cone to their eventual sites of deposition. 


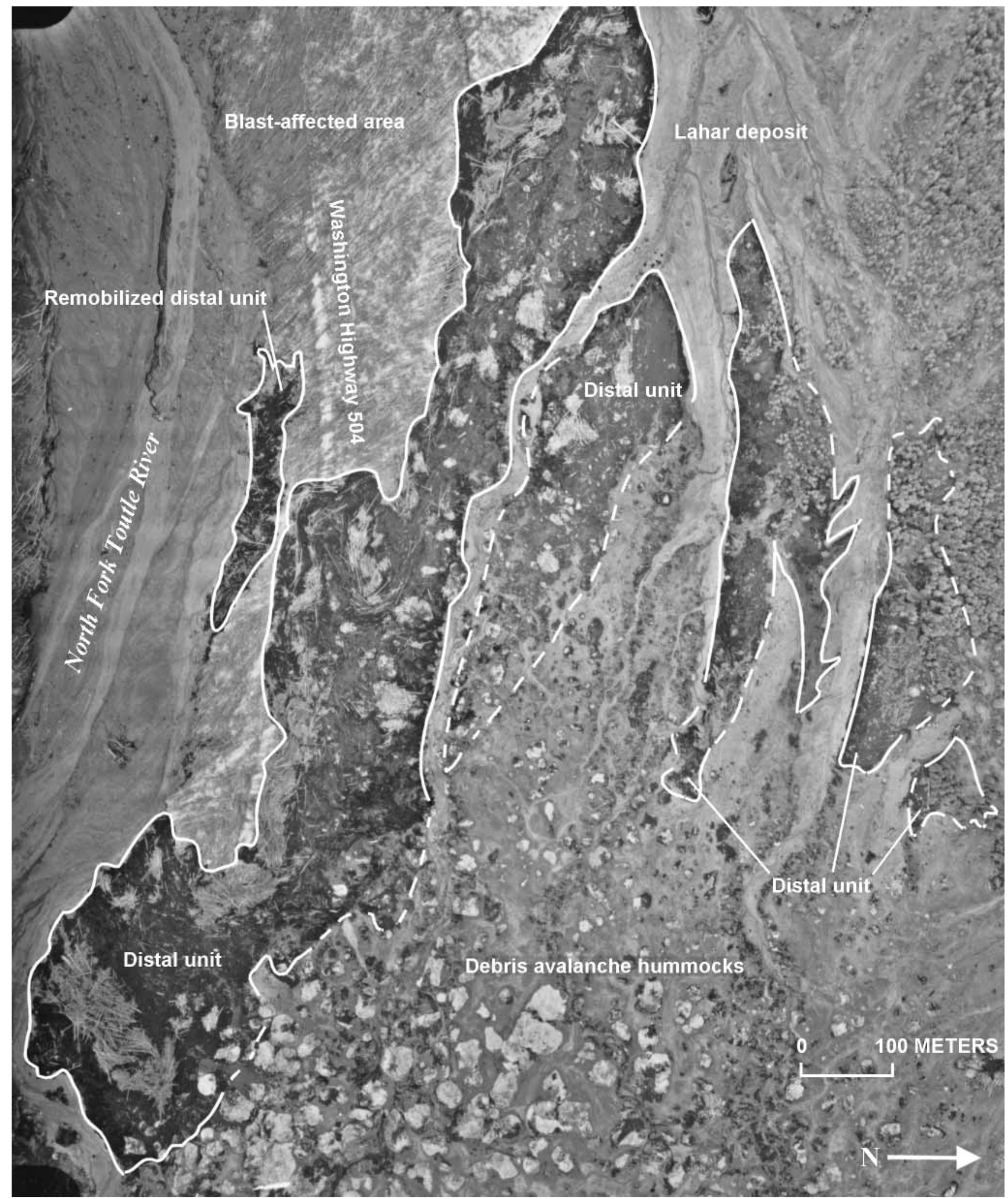

Figure 15. Aerial photograph of distal end of debris-avalanche deposit, showing woody hummocks of distal unit. Photograph taken May 19, 1980, by Washington State Department of Transportation. Dashed where extent of distal unit uncertain. 


\section{MORPHOLOGIC MAP OF THE DEBRIS- AVALANCHE DEPOSIT}

Six morphologic map units are defined within the avalanche deposit (modified slightly from Voight and others, 1981). They are referred to here as the North Fork, Johnston Ridge, Spirit Lake, marginal, proximal, and distal units, named according to representative locations in the deposit (pl. 3). Other kinds of deposits of the May 18 eruption, including blast deposits, lahar deposits, and pyroclastic-flow deposits (Lipman, 1981), partly cover the avalanche deposit and are mapped where they conceal the hummocky surface.

\section{NORTH FORK UNIT}

The North Fork unit comprises the bulk of the debrisavalanche deposit. It is defined as the part of the debrisavalanche deposit between and including the levees in the valley of the North Fork Toutle River that did not encounter Johnston Ridge or Spirit Lake. It extends from the base of the northern flank of the mountain to within $1 \mathrm{~km}$ of the distal end.

The most characteristic morphologic feature of the North Fork unit are hummocks (fig. 16) that have as much as $75 \mathrm{~m}$ of relief. The shape of the hummocks is very irregular, but some are roughly circular in plan and rise to a peak or a dome. Locally, they are elongate in the direction of flow and are difficult to distinguish from levees. The formation of the hummocks is discussed in "Geometry of the Deposit".

Levees as much as $30 \mathrm{~m}$ high are also characteristic features of the North Fork unit. Levees are defined as linear ridges near the margins of the avalanche deposit that locally widen into linear zones of irregular positive topography (figs. 17 and 18). They generally occur against valley walls and block the mouths of tributaries (fig. 17), where they mark the contact between the North Fork and marginal units. Commonly, two or more parallel, ill-defined levees are present within the North Fork unit. In many areas, such as the area just north of Castle Lake, levees extend to the central part of the North Fork unit. These may also be considered hummocks with the long axes aligned in the direction of flow, which form in a way similar to the way levees form (see "Geometry of the Deposit").

The morphology of the levee that blocks Coldwater Lake suggests that it is an imbricate structure made up of discrete masses of debris separated by thrust faults (fig. 18). The chaotic lithologic pattern of the area (pls. 4 and 5 ) is consistent with a thrusted imbricate structure, even though the imbrication is not readily apparent on the map. The structure is interpreted to result from the depo-

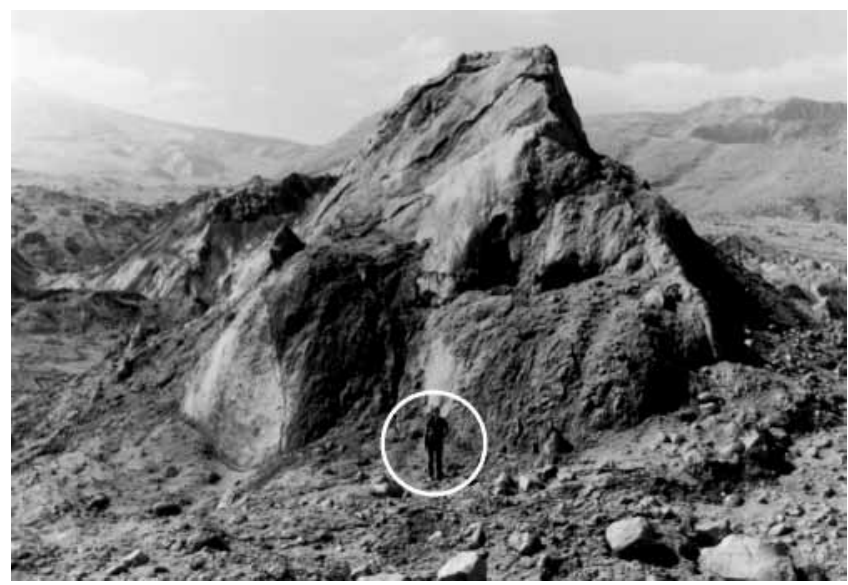

Figure 16. Typical hummock of North Fork unit. Note person for scale (circle).

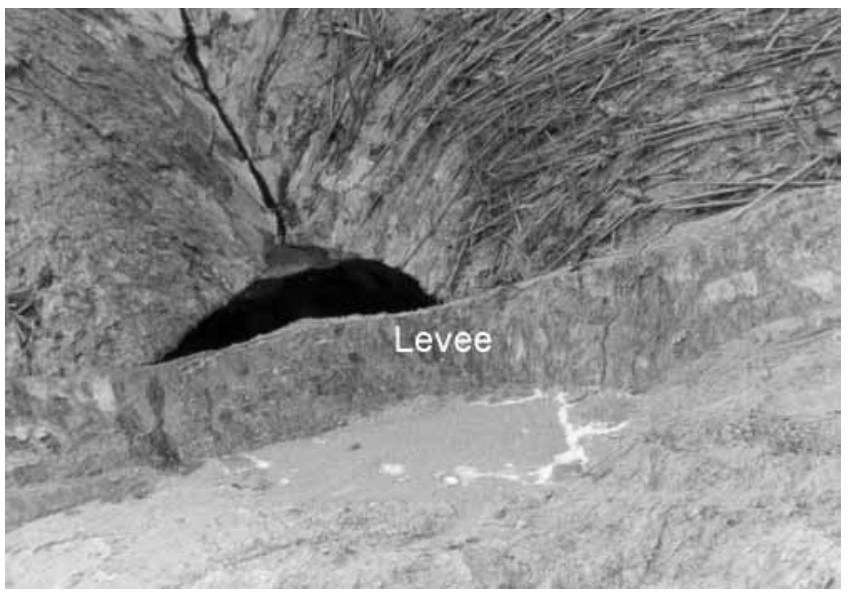

Figure 17. Levee of North Fork unit blocking mouth of small stream near sample locality DXS-32. Blasted trees rest on Tertiary bedrock.

sition of material with enough shear strength to remain intact except along narrow zones.

Closed depressions are also common features of the North Fork unit. Most of the depressions that are irregular in plan usually represent interhummock areas. The formation of hummocks and interhummock areas is discussed in "Geometry of the Deposit".

A few of the closed depressions are roughly circular, measure as much as $240 \mathrm{~m}$ wide and $50 \mathrm{~m}$ deep, and have sides considerably steeper than the surrounding local relief (base map of pl. 4). Nearly all the circular closed depressions visible on the topographic maps probably formed within hours to days after emplacement of the debris-avalanche deposit; I saw many depressions on May 27, 1980, and many are visible on the oblique aerial photographs taken by Austin Post (U.S. Geological Survey, Tacoma, Wash.) on May 19. However, a few new 


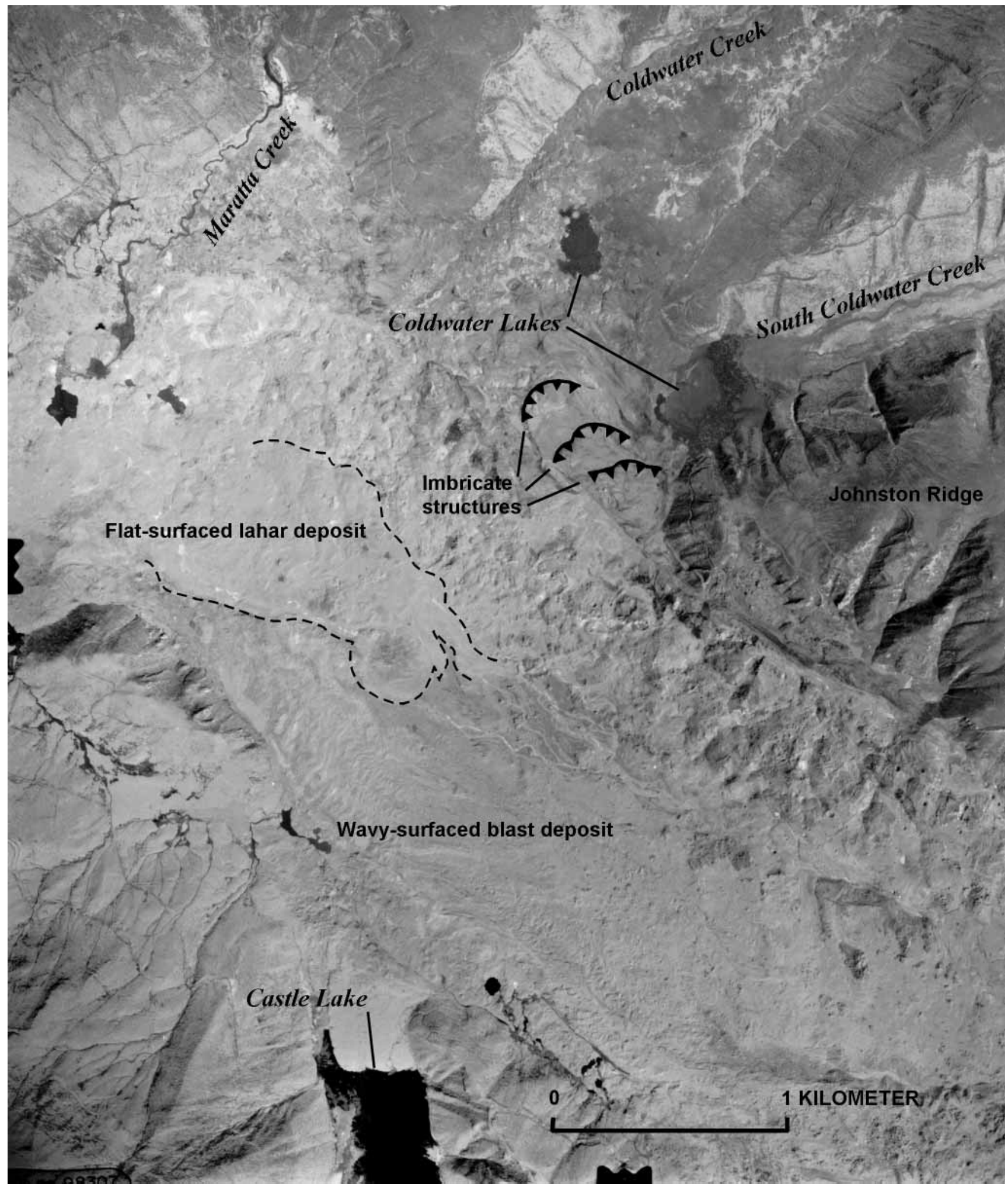

Figure 18. Aerial photograph of debris-avalanche deposit in area around Castle and Coldwater Lakes. Imbricate structures near Coldwater Lake shown. Blast deposit has wavy surface showing transverse dunes where it was deposited against margin of debrisavalanche deposit. Photograph taken June 19, 1980, Washington State Department of Natural Resources. 
closed depressions were observed in the summer of 1982 (Glicken and others, 1989).

The circular closed depressions (craters) are interpreted to have been formed by collapse into void space. The void space may have been between debris-avalanche blocks of the block facies or may have been created by melted glacial ice. Most of the ice must have melted within hours to days after emplacement. However, ice was observed on the surface of the deposit for many weeks after May 18 (fig. 19) and ice was uncovered during excavations for an outlet for Spirit Lake in summer 1982 (Glicken and others, 1989). If ice was to have melted within hours to days after emplacement to produce void space, the pieces of ice must have been small or must have been adjacent to a substantial source of heat. Modeling by Fairchild $(1985,1987)$ suggests that ice clasts with diameters $>1 \mathrm{~m}$ would not have melted by late afternoon of May 18, assuming that the debris avalanche was emplaced at a temperature of $98{ }^{\circ} \mathrm{C}$ (the maximum measured temperature; Voight and others, 1983).

Some authors (for example, Fairchild, 1985, 1987) suggest that most of the collapse craters resulted from collapse into void space created by melted ice. However, when the rockslide expanded by more than 20 percent to become the debris-avalanche deposit (see "Texture of the Deposit"), $0.4 \mathrm{~km}^{3}$ of void space was created. This amount is far more than the total void space that would have been created had the $0.1 \mathrm{~km}^{3}$ of ice incorporated in the debris avalanche (Brugman and Meier, 1981) melted completely. This suggests that most of the collapse craters resulted from collapse into void space in the debrisavalanche deposit created during dilation and breakup of the rockslide material rather than from collapse into void space created by melting ice. Alternatively, it is possible that larger voids were created by melting ice than by dilation, and the larger voids were more likely to form collapse craters.

There were numerous channels near the distal end of the debris-avalanche deposit the day after emplacement (fig. 20). On the afternoon of the eruption, I witnessed some of these channels being filled with flowing mud. Multiple terraces of lahar deposits along these channels suggest that repeated lahar flows, or a lahar with varying depth, came down the channel. The channels probably were eroded by the lahars generated on the debris-avalanche deposit (Fairchild, 1985, 1987). The main channel is the path of the major lahar that flowed west down the North Fork Toutle River valley. The tributary channels likely formed from headward retreat of slumps of the main channel walls.

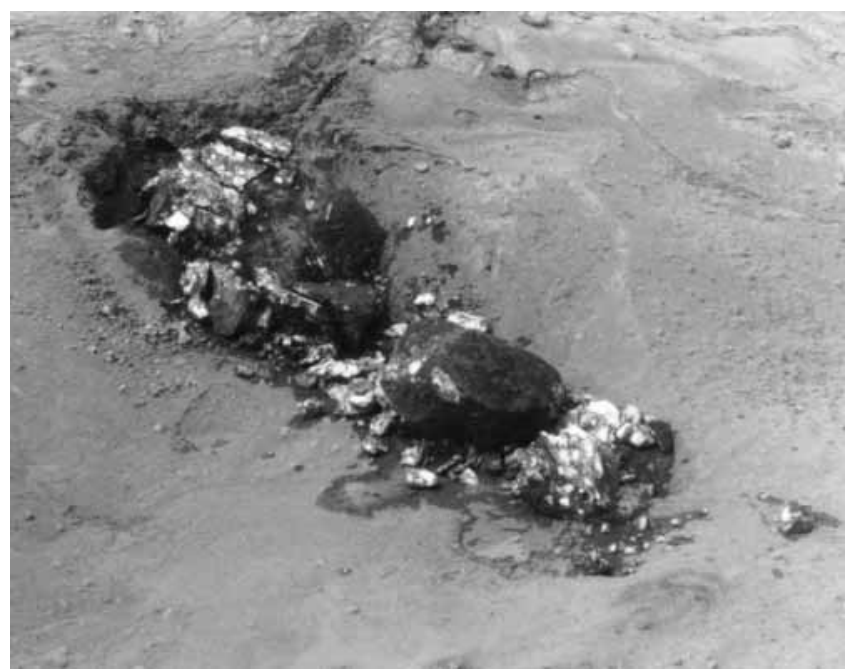

Figure 19. Ice fragments on surface of deposit, May 31, 1980. Largest piece about $3 \mathrm{~m}$ wide.

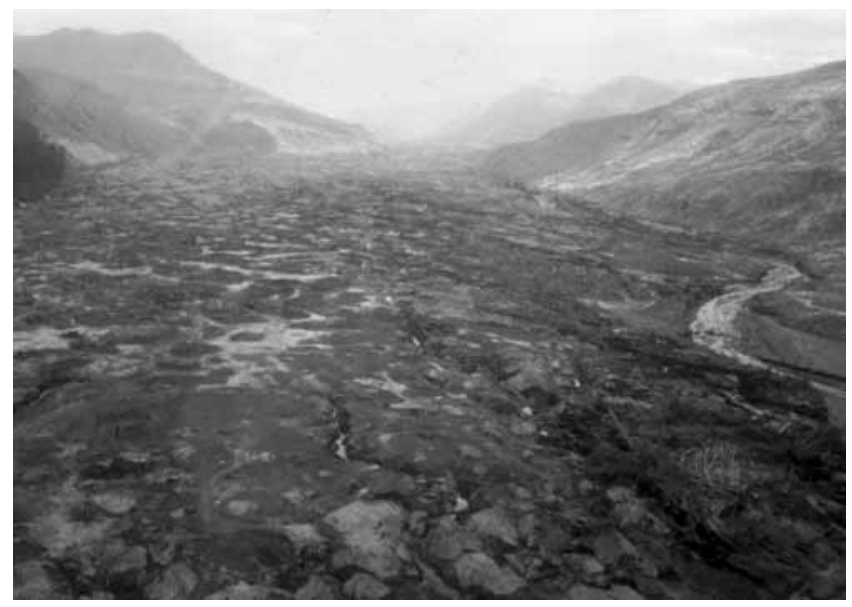

Figure 20. Distal end of the debris-avalanche deposit, showing channels probably eroded by May 18 lahars. View about $1.3 \mathrm{~km}$ wide at center of photograph. Photograph by C.D. Miller, U.S. Geological Survey.

\section{JOHNSTON RIDGE UNIT}

The Johnston Ridge unit was originally called the Coldwater Ridge unit (Voight and others, 1981). It is renamed here because the ridge was officially named "Johnston Ridge" in 1983 (U.S. Board on Geographic Names, 1984). It is defined as those parts of the debrisavalanche deposit that interacted with Johnston Ridge, and it is present only on and adjacent to Johnston Ridge. It is as much as 195 m thick.

In tributary basins of the North Fork Toutle River on the south slope of Johnston Ridge, the debris avalanche has formed thick (as much as $195 \mathrm{~m}$ ) deposits that are perched as high as $150 \mathrm{~m}$ above the deposit in the North Fork Toutle Valley. In these basins, hummocks locally 


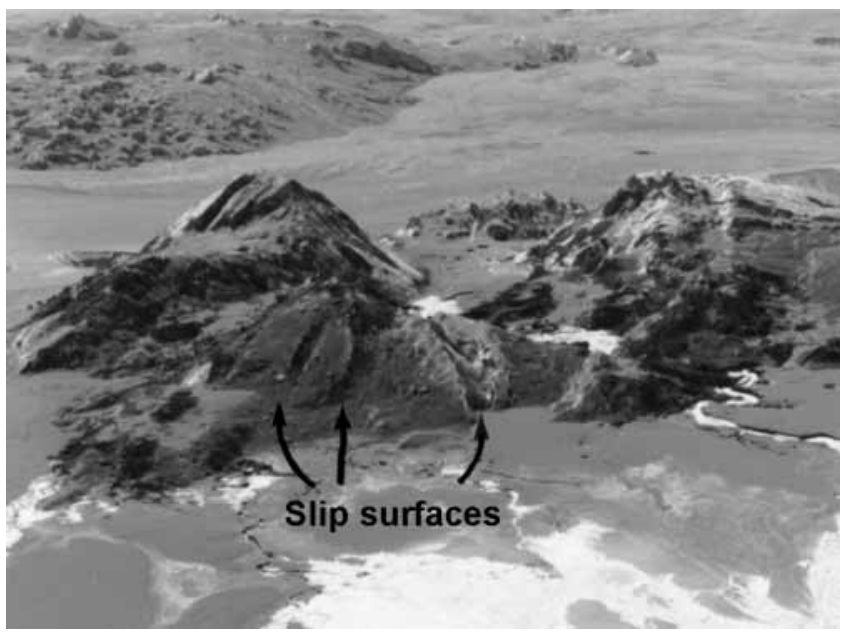

Figure 21. Post-depositional slip in hummocks on terraces on Johnston Ridge. View about 375 m wide.

show evidence for slip in a southerly, downslope direction (fig. 21), indicating that parts of the debris moved back towards the main part of the debris avalanche ("fallback ridges" of Kojan and Hutchinson, 1978). In a tributary channel just west of Harry's Ridge, the Johnston Ridge unit forms a ramp that extends from the Pumice Plain to the top of Johnston Ridge (fig. 22). This feature, called "The Spillover" (U.S. Board on Geographic Names, 1984) was referred to as a "depositional ramp" by Ui and Aramaki (1983). A depositional ramp is defined as a high-angle slope on the surface of a large-scale pyroclastic flow (Suzuki and Ui, 1982); it is not strictly applicable to the debris-avalanche deposit.

The debris avalanche crossed Johnston Ridge at The Spillover and at a pass $1 \mathrm{~km}$ west of The Spillover. The debris avalanche scoured Johnston Ridge and adjacent Harry's Ridge of all soil and trees before depositing material in South Coldwater Creek, just north of Johnston Ridge (Fisher and others, 1987).

The topography of the Johnston Ridge unit of the debris avalanche is, on average, much more irregular than that of the North Fork unit. Hummocks are generally elongate in plan (figs. 21 and pl. 2), reflecting fall back. In the avalanche debris blocking Spirit Lake (the "Spirit Lake Blockage" of Glicken and others, 1989) there are many pits as much as $240 \mathrm{~m}$ wide and $35 \mathrm{~m}$ deep. Because no deposits of phreatic eruptions are found adjacent to most of them, most of the pits are believed to have been formed by collapse rather than by phreatic eruptions.

\section{SPIRIT LA KE UNIT}

The Spirit Lake unit is that part of the debris-avalanche deposit that moved to the northeast and displaced

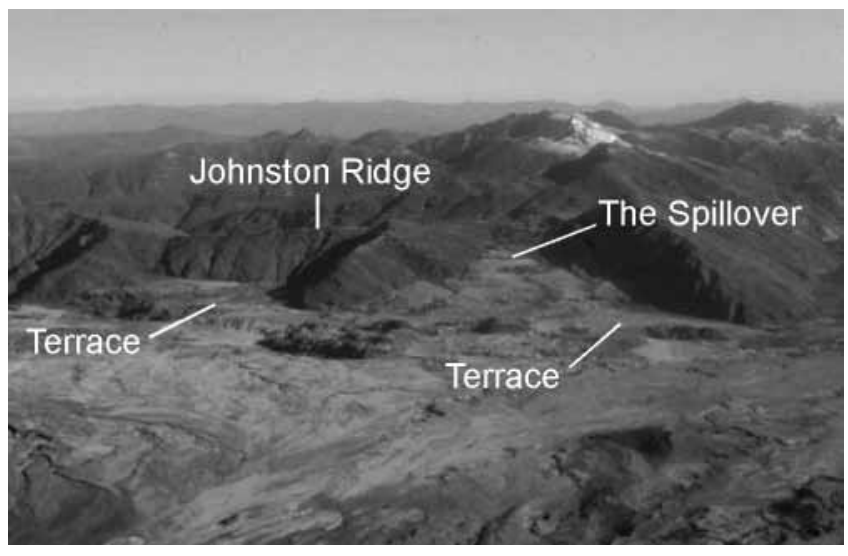

Figure 22. Oblique view, looking north from crater, showing ramp (The Spillover) and terraces on Johnston Ridge. View about $3 \mathrm{~km}$ wide at ridge. Photograph by Terry Leighley, Sandia National Laboratory, July 8, 1981.

Spirit Lake. The Spirit Lake unit occurs only in the region surrounding the lake. It is only a few meters thick on the shores of the lake, but it is as much as $100 \mathrm{~m}$ thick beneath the lake (Meyer and Carpenter, 1982).

The avalanche and blast caused a seiche to rise up from the lake. The seiche, along with the avalanche itself, scoured the trees, vegetation, and soil from the ridges adjacent to the lake to heights of more than $260 \mathrm{~m}$ (Voight and others, 1981). The scoured area is part of the area designated as the "tree removal zone" by Lipman (1981).

The scouring mixed Spirit Lake water with clasts of the Tertiary bedrock to form lahars. Deposits of these lahars are found under and between hummocks in the Bear Cove area north of the northwest arm of Spirit Lake. Continued sloshing of the lake likely resulted in the erosion of the hummocks to produce the conical forms (fig. 23 and base map of pl. 4) that are unique to this part of the debris-avalanche deposit. Blasted trees were left stranded on top of some of the hummocks (fig. 23). The lake then rushed back into its newly created basin, eroding large, boxlike canyons just north of the northwest arm of the lake.

The lahars that flowed down to the lake from the area about $2 \mathrm{~km}$ to the south of the lake (pls. 3 and 4) probably resulted from the southward sloshing of Spirit Lake water that mobilized thick blast deposits. There is no other source of water for these lahars; they are many kilometers from possible sources of water in the crater of Mount St. Helens.

\section{MARGINAL UNIT}

The marginal unit, as much as $75 \mathrm{~m}$ thick, backfills tributaries of the North Fork Toutle River. It is defined as 


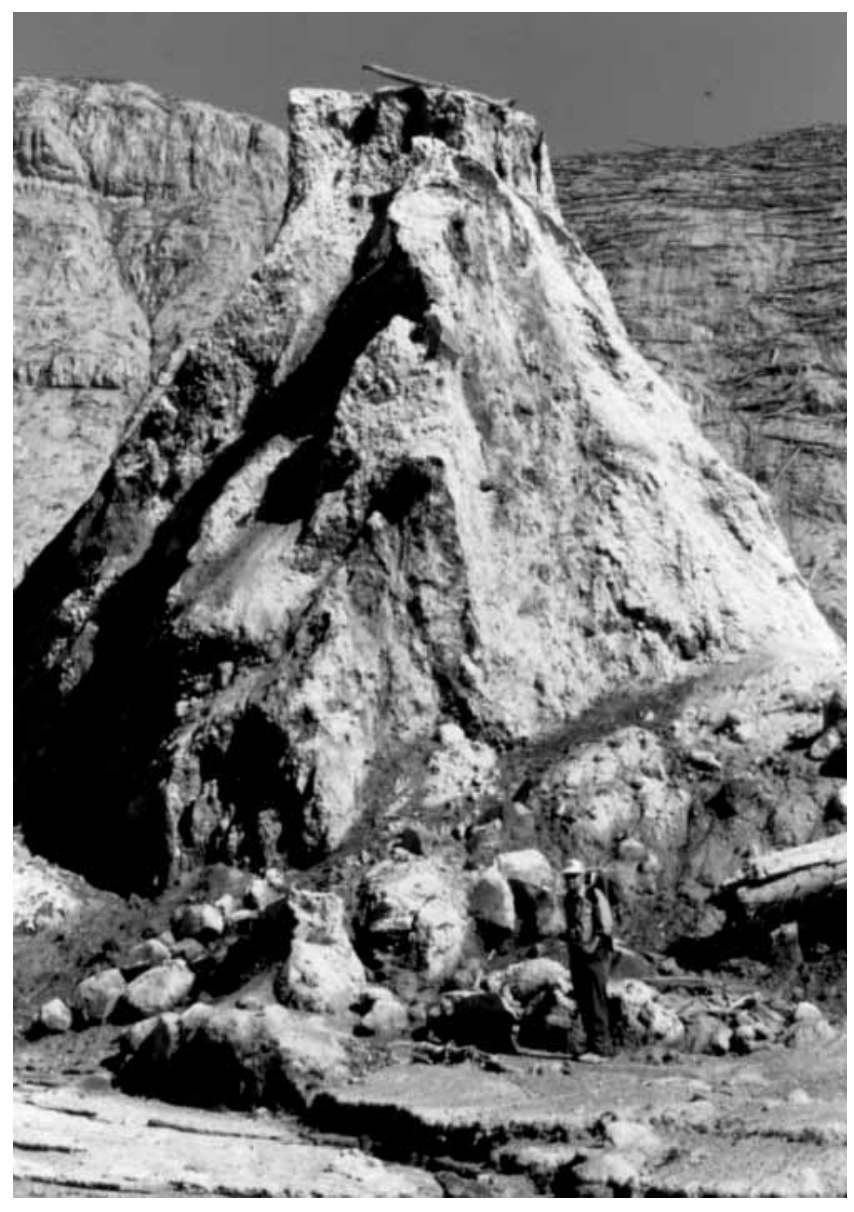

Figure 23. Conical hummock north of northwest arm of Spirit Lake. Blasted trees stranded on top of hummock; lahar deposits rich in clasts of Tertiary bedrock between hummocks.

the parts of the debris-avalanche deposit on the valley wall side of the levees of the North Fork unit. It generally forms lobate deposits (fig. 24), but hummocks that closely resemble those in the valley of the North Fork Toutle River are also locally present. The lobes, where they do not abut against valley walls, exhibit flow fronts as much as $5 \mathrm{~m}$ high.

The lobes of the marginal unit are truncated by levees of the North Fork unit. This distribution suggests that the marginal unit was pushed in front and to the side of the main mass of the moving debris avalanche and came to rest while the North Fork material was still in motion.

\section{PROXIMAL UNIT}

The proximal unit is the part of the debris-avalanche deposit in the crater and on the north slope of Mount St. Helens. Hummocks of this unit in the north part of the crater are some of the largest hummocks in the debris avalanche; they are as much as $100 \mathrm{~m}$ high and 1,000 m wide. Proximal hummocks are much smaller on the mountain slope just north of the crater.

The proximal unit covers the crater floor and had a hummocky surface before it was extensively eroded by pyroclastic flows (fig. 25). In one locality, the density was $1.72 \mathrm{~g} / \mathrm{cm}^{3}$; this value is consistent with measurements of debris-avalanche deposits rather than the old mountain material (see "Texture of the Deposit"). Malone and Pavlis (1983) indicate that a sharp seismic velocity contrast exists at a depth of as much as $150 \mathrm{~m}$, so the proximal unit in the crater is probably as much as $150 \mathrm{~m}$ thick (fig. 2).

On the north flank of the volcano, the proximal unit is not continuous. It occurs in isolated areas separated by many meters. Hummocks are contiguous in the areas mapped as "proximal hummocks" (fig. 26), whereas in the areas mapped as "proximal scattered," hummocks are small ( $<3 \mathrm{~m}$ wide), scattered, and rest on pre-1980 material. The debris-avalanche deposit forms less than 1 percent of the surface area in the area mapped as proximal scattered.

There is abundant evidence for interaction of the 1980 debris avalanche with the older deposits on the north flank of Mount St. Helens that underlie the proximal unit. The older deposits consist of deposits from talus and nonvesiculated pyroclastic flows from the Goat Rocks dacite dome, as well as lava flows and volcaniclastic deposits from the Kalama and Castle Creek eruptive periods (C.A. Hopson, written commun., 1980). Scratches resembling glacial striations (fig. 27), interpreted to result from abrasion of the underlying material by the debris avalanche, are present on most of the surface of the older deposits. On the northeast flank of the mountain, some of the pre1980 volcaniclastic deposits were carried away by the avalanche, and only drumlin-shaped remnants of these deposits are left. All the vegetation was stripped from the north flank except for burned bits of wood in rock crevices and on the lee (downhill) side of lava flow outcrops more than $2 \mathrm{~m}$ high.

\section{DISTAL UNIT}

The distal unit, present only at the west end of the debris-avalanche deposit, consists primarily of jumbled mounds of broken trees, wood debris, and organic soil (fig. 28). Mixed with this material are volcanic clasts from Mount St. Helens, in proportions of as much as 30 percent. Also incorporated into the distal unit are pavement fragments (fig. 29) and other miscellaneous debris from the North Fork Toutle River valley. The material is generally $<10 \mathrm{~m}$ thick (pl. 1) and probably averages about $5 \mathrm{~m}$ thick.

Most of the distal unit was destroyed during construction of a U.S. Army Corps of Engineers' sediment reten- 


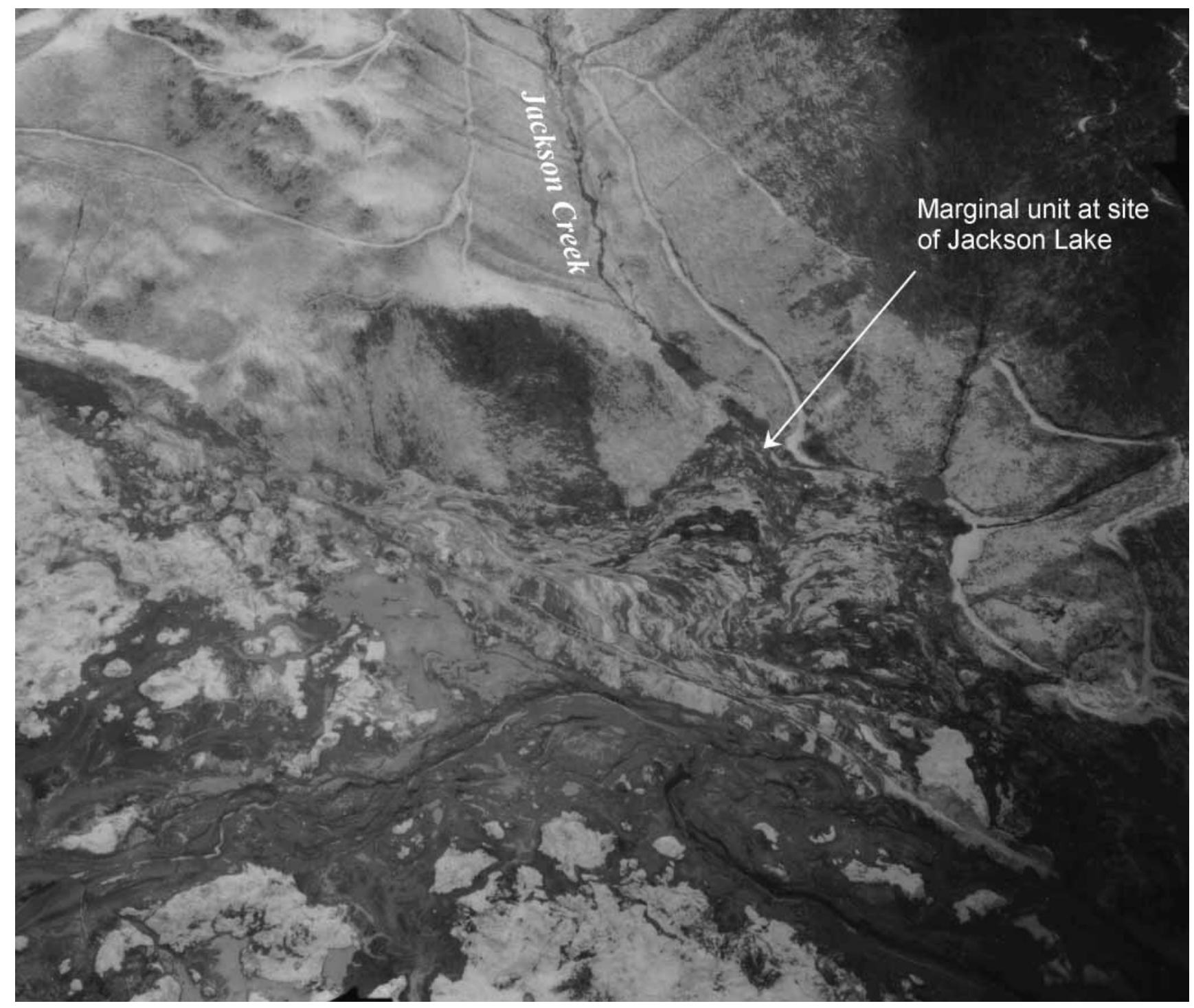

Figure 24. Oblique aerial photograph of lobate deposits of marginal unit at site of Jackson Lake. Photograph by Austin Post, U.S. Geological Survey, May 19, 1980. View southeast. Field of view approximately 1 km.

tion structure (dam) in the summer and fall of 1980. Much of the area of the distal unit was then covered by alluvium and lahars that were deposited behind the dam.

Hummocks in the distal unit are very similar in shape and size to those on the west end of the North Fork unit (pl. 4 and fig. 15). They are as much as $9 \mathrm{~m}$ high and generally roughly circular in plan. Unlike the hummocks of the North Fork unit, they bristle with trees.

The distal unit has a flow front that is as much as $8 \mathrm{~m}$ high. Locally, more fluid parts of the unit ramp down from the main mass of material and grade into the lahar deposits of the North Fork Toutle River valley.

The contact between the distal and North Fork units is generally gradational over $10-20 \mathrm{~m}$, but it is locally sharp and dips $5^{\circ}-7^{\circ}$ to the west (fig. 30). The dip of the contact and the distribution of the deposit suggests that the distal unit represents a part of the forest in the North Fork Toutle River valley that was felled by the blast and subsequently pushed in front of the debris avalanche.

\section{LITHOLOGIC MAP}

Six lithologic units of the debris avalanche are differentiated on the lithologic map (pl. 4). The older dacite, modern dacite, andesite and basalt, and modern undifferentiated units make up blocks within the block facies (pieces of the old mountain that were transported from their origin relatively intact). The mixed block and matrix facies is composed of blocks of varying lithology as well as the matrix facies, a blended mixture of all rock 


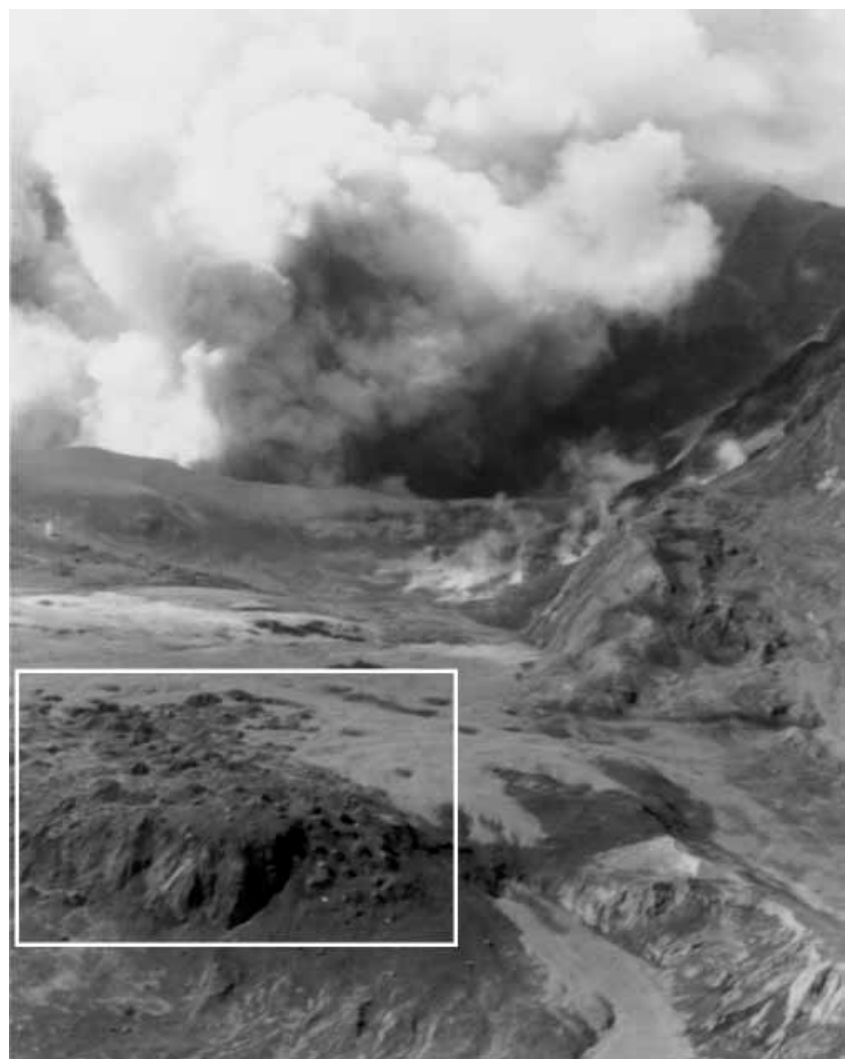

Figure 25. Oblique aerial photograph of hummocky proximal unit in crater before erosion. Photograph by R.L. Christiansen, U.S. Geological Survey, May 22, 1980. Back crater wall about $750 \mathrm{~m}$ high.

types from the old mountain, the juvenile blast dacite, and material picked up from the surrounding terrain. Texture and facies are discussed in more detail in "Texture of the Deposit". The distal unit is included on the lithologic map; it is described in the preceding section.

The lithologic map was compiled only where the TVGT base map exists. The area of the proximal and much of the Johnston Ridge morphologic units are not included on the map, which covers primarily the river channels. Although the base map topography is from summer 1980, the lithologic map shows fluvial modification up to summer 1982, when most of the mapping was done.

\section{BLOCK FACIES UNITS}

\section{OLDER DACITE UNIT}

The older dacite unit consists almost entirely of the hornblende-hypersthene dacite from pre-Castle Creek (older than 2,500 yr) Mount St. Helens (C.A. Hopson, written commun., 1984). It is derived from the older dacite unit observed in the 1980 crater (see "Introduction"). The rock types in the older dacite unit in the

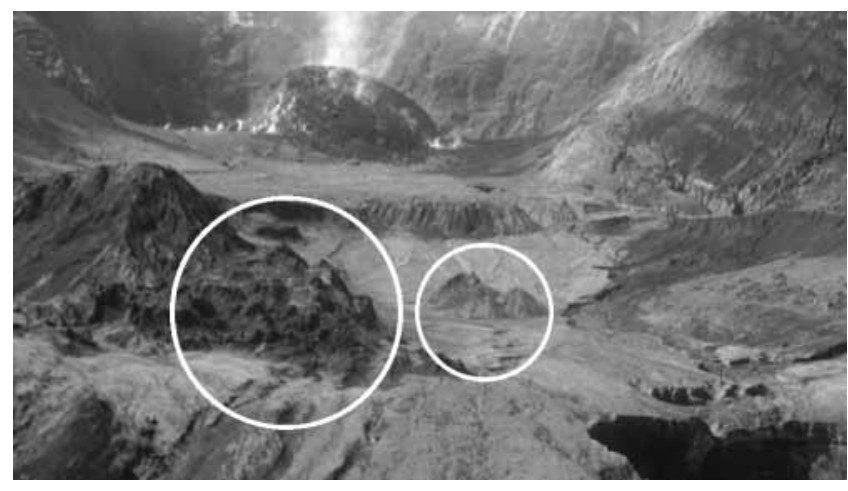

Figure 26. Hummocks of proximal unit on north flank of Mount St. Helens (circles). Hummocks in small circle about $100 \mathrm{~m}$ wide. Photograph by Terry Leighley, Sandia National Laboratory, July $14,1981$.

debris-avalanche deposit are identical to those in the older dacite unit in the crater. The hornblende-hypersthene dacite is readily recognizable in the field because it has abundant large ( $>2 \mathrm{~mm}$ length) phenocrysts of plagioclase and hornblende. Xenoliths of varying composition are locally present.

Pre-1980 hydrothermal and fumarolic alteration colored the rocks within the unit many shades of gray, red, pink, yellowish-brown, and green. Although much of the alteration occurred within the old volcano, vertical patterns of alteration, accompanied by pyrite mineralization, are present locally in the unit adjacent to fumaroles and hot springs, providing evidence for some post-emplacement alteration.

Minor amounts of other rock types are present in the older dacite unit, the most common being bodies of dark, fine-grained andesite and basalt. These bodies locally are narrow and elongate in outcrop and are commonly cross cut by faults (fig. 31). The shape of many of the narrow and elongate bodies is quite similar to the shape of narrow and elongate dikes visible on the walls of the crater (fig. 7). Although some of the narrow and elongate bodies in the debris-avalanche deposit could be clastic dikes resulting from injection of material into cracks during transport of the debris avalanche, the contrast in rock types and the similarity with the dikes in the crater suggest that most of these bodies are igneous dikes. The dikes were transported in blocks (pieces of the old mountain) from their positions in the pre-1980 volcanic edifice without completely disaggregating.

Locally, clastic dikes can be distinguished from igneous dikes. A hummock with both type of dikes exposed (fig. 32) has a dike composed of andesite with a relatively dark, chilled margin on both sides; these features indicate that its origin was volcanic. The other dike cuts across the volcanic dike and consists of fragments of the older dac- 


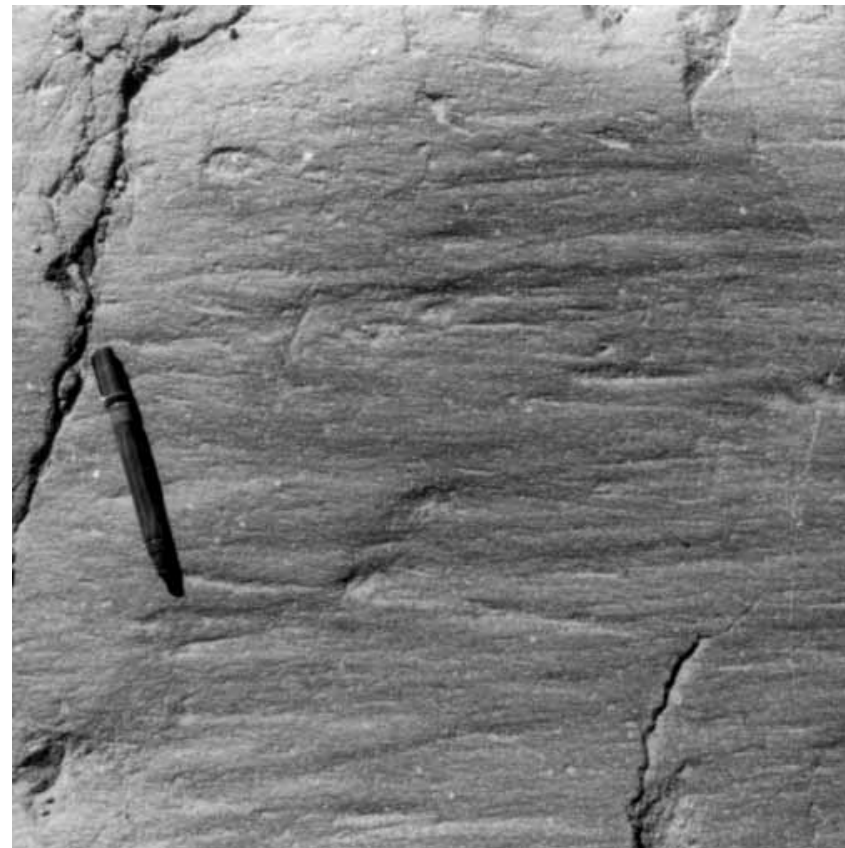

Figure 27. Scratches resembling glacial striations on north flank of Mount St. Helens, suggesting abrasion by debris avalanche moving over surface. Debris avalanche moved from left to right.

ite, which is older than the andesite (fig. 3); the second dike is a clastic dike that formed in the debris avalanche.

The bodies of rock types other than older dacite within the older dacite unit that are not narrow and elongate are more difficult to interpret. Commonly, the bodies are discontinuous and are scattered through small areas of the older dacite unit. Examination of photographs of the crater wall (for example, fig. 4) indicates that andesite and basalt dikes make up roughly 5-10 percent of the older dacite unit, roughly the same percentage as the andesite and basalt material in the older dacite unit of the debris-avalanche deposit. This suggests that most of the andesite and basalt in the older dacite unit was formed in volcanic dikes in the old mountain and subsequently disaggregated and partially blended with the older dacite during transport of the debris avalanche. However, it is probable that minor amounts of the foreign material originally cooled as andesitic or dacitic lava flows above the older dacite core and partially mixed with older dacite during the transport of the debris avalanche.

\section{ANDESITE AND BASALT UNIT}

The andesite and basalt unit is rubble consisting of two-pyroxene andesite and olivine basalt. The rocks are derived from andesite and basalt lava flows and volcaniclastic rocks from the Castle Creek, Kalama, and Goat

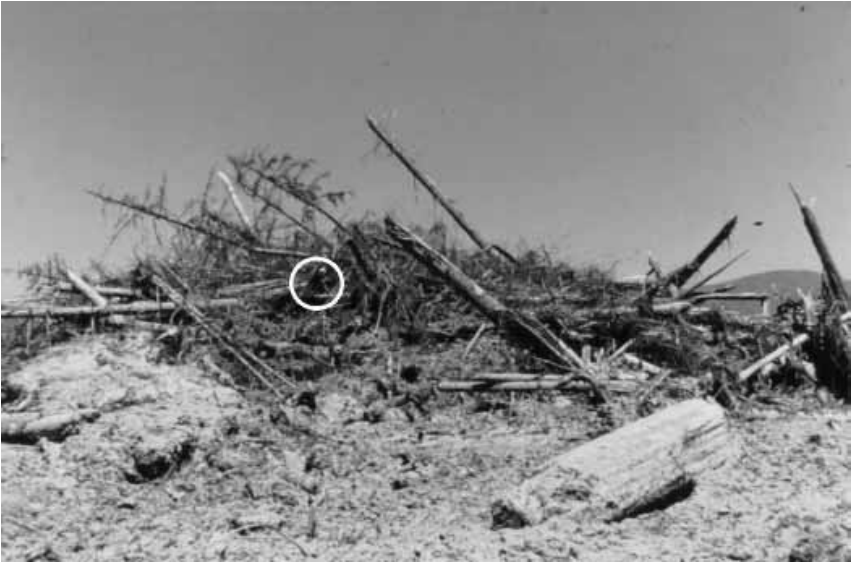

Figure 28. Jumbled hummocks of woody debris in distal unit. Man (circle) is about $1.7 \mathrm{~m}$ tall.

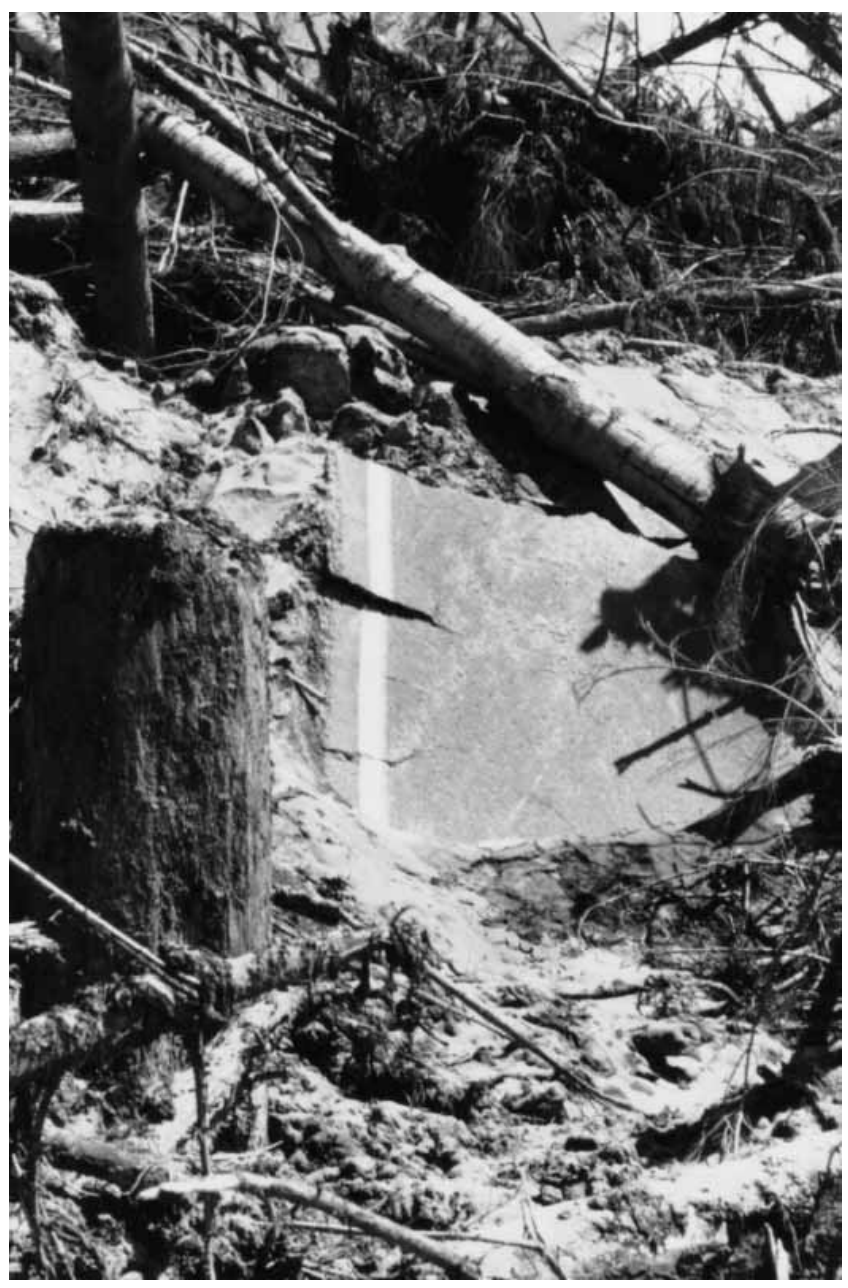

Figure 29. Pavement fragment, about $2 \mathrm{~m}$ wide, in distal material. Road is Washington State Highway 504. 


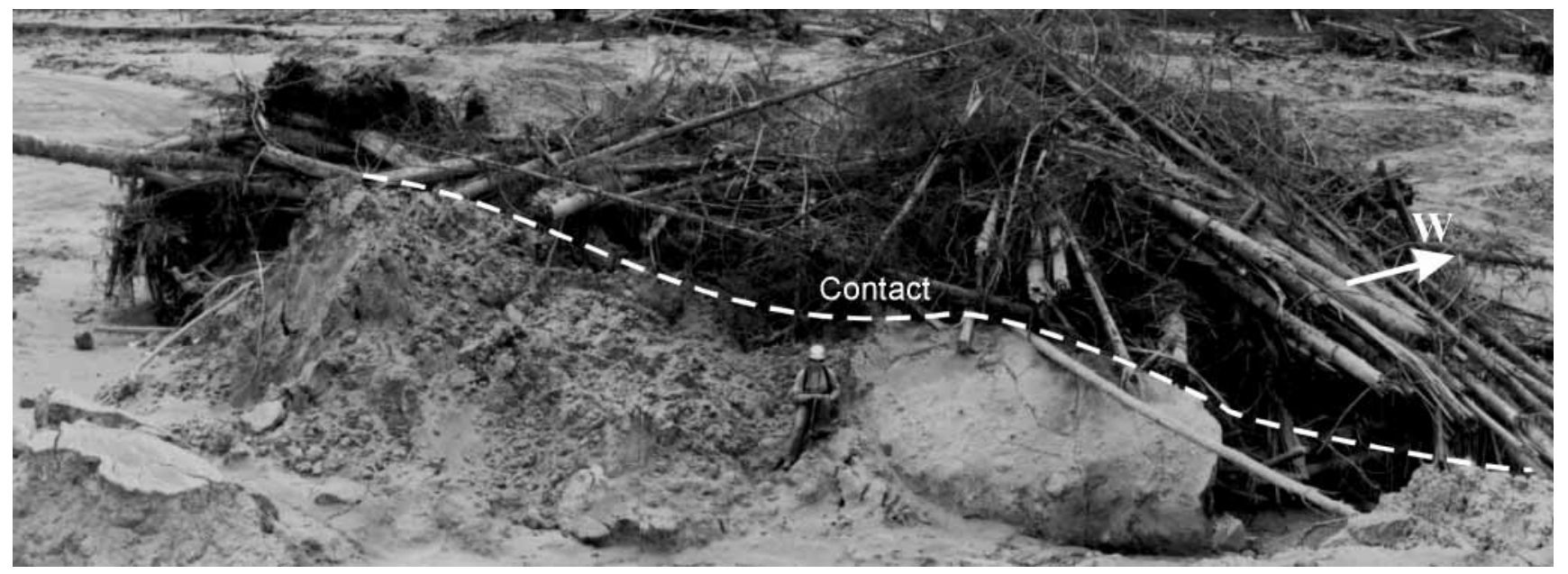

Figure 30. Dipping contact between distal and North Fork units. Contact dips $5^{\circ}-7^{\circ}$ to west.

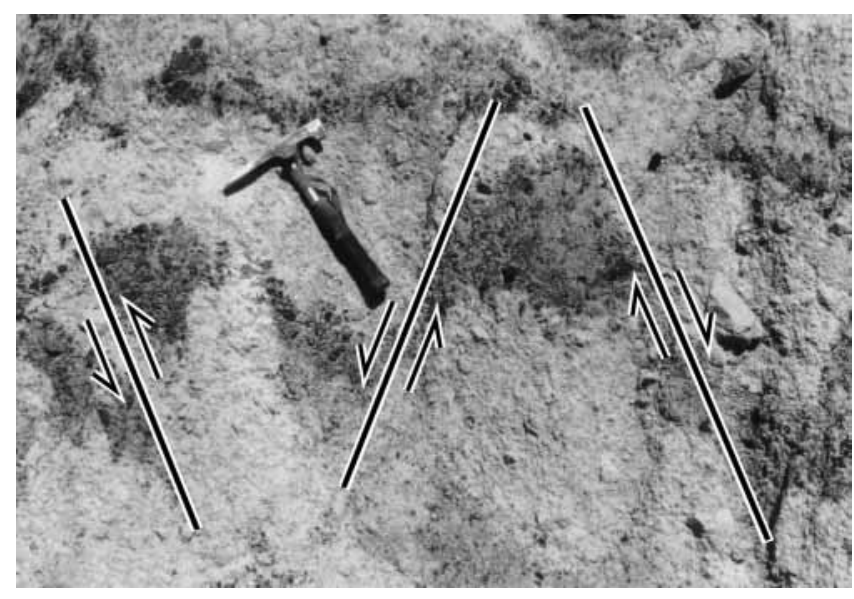

Figure 31. Narrow and elongate volcanic dikes in debris-avalanche deposit cross cut by faults.

Rocks eruptive periods of Mount St. Helens (C.A. Hopson, written commun., 1980), now exposed in the upper part of the 1980 crater (see "Geology of the Source Area").

The andesites and basalts are generally black or dark gray but locally are various shades of red and very dark green when hydrothermally altered. The andesites, which are generally plagioclase porphyritic, contain varying amounts of hypersthene and augite. Olivine is rare and usually occurs as phenocrysts $<1 \mathrm{~mm}$ wide. The basalts generally are olivine phyric. Both andesite and basalt are variably vesicular and locally are extremely scoriaceous.

Locally, roughly horizontal flow structures within pre-1980 lava flows or flow breccias were preserved during transport of the material in the rockslide-debris avalanche. These are expressed (fig. 33) either as bands of material of different clast sizes or as horizontal bands of material of different colors that represent different

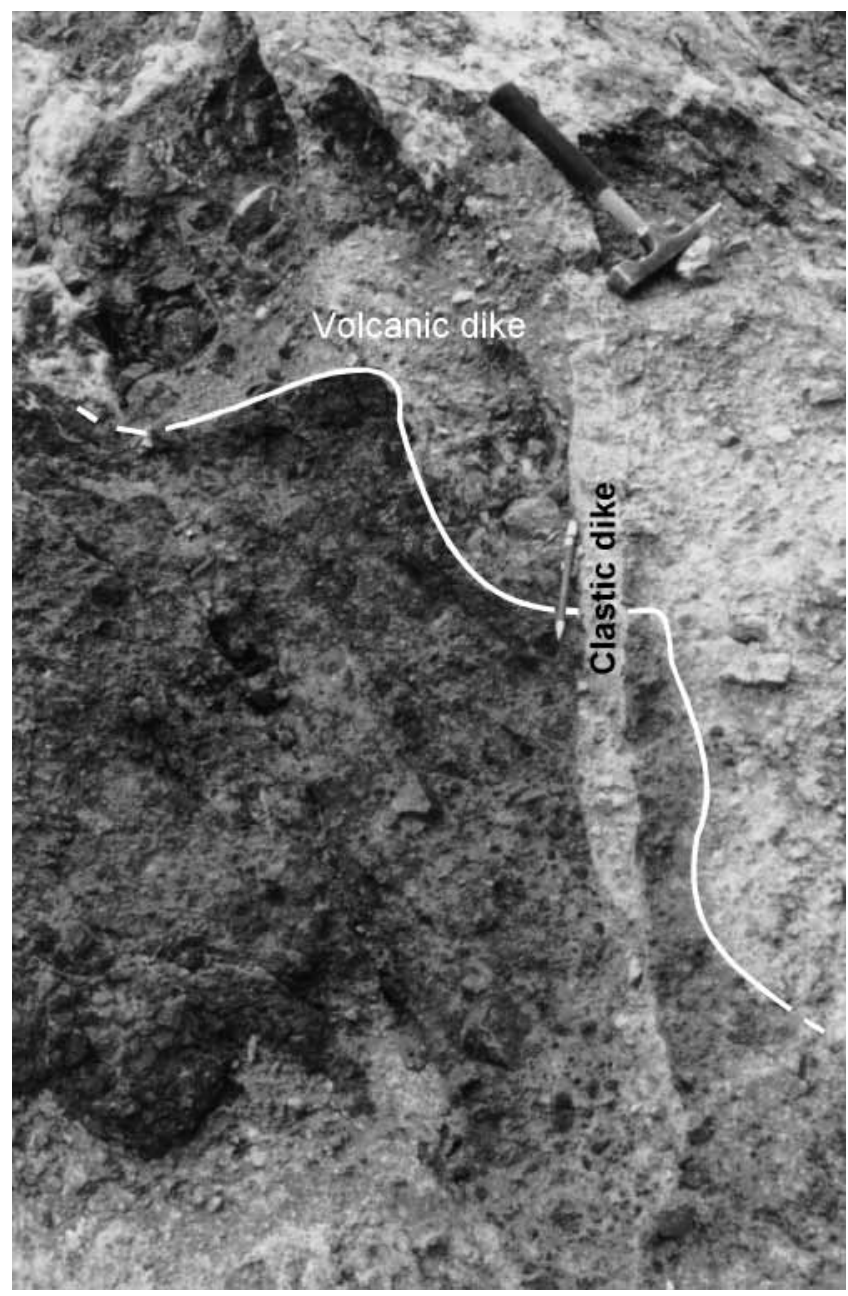

Figure 32. Volcanic dike and clastic dike in same hummock of debris-avalanche deposit. Volcanic dike has chilled margin. Clastic dike intrudes volcanic dike and contains rocks older than the volcanic dike. 

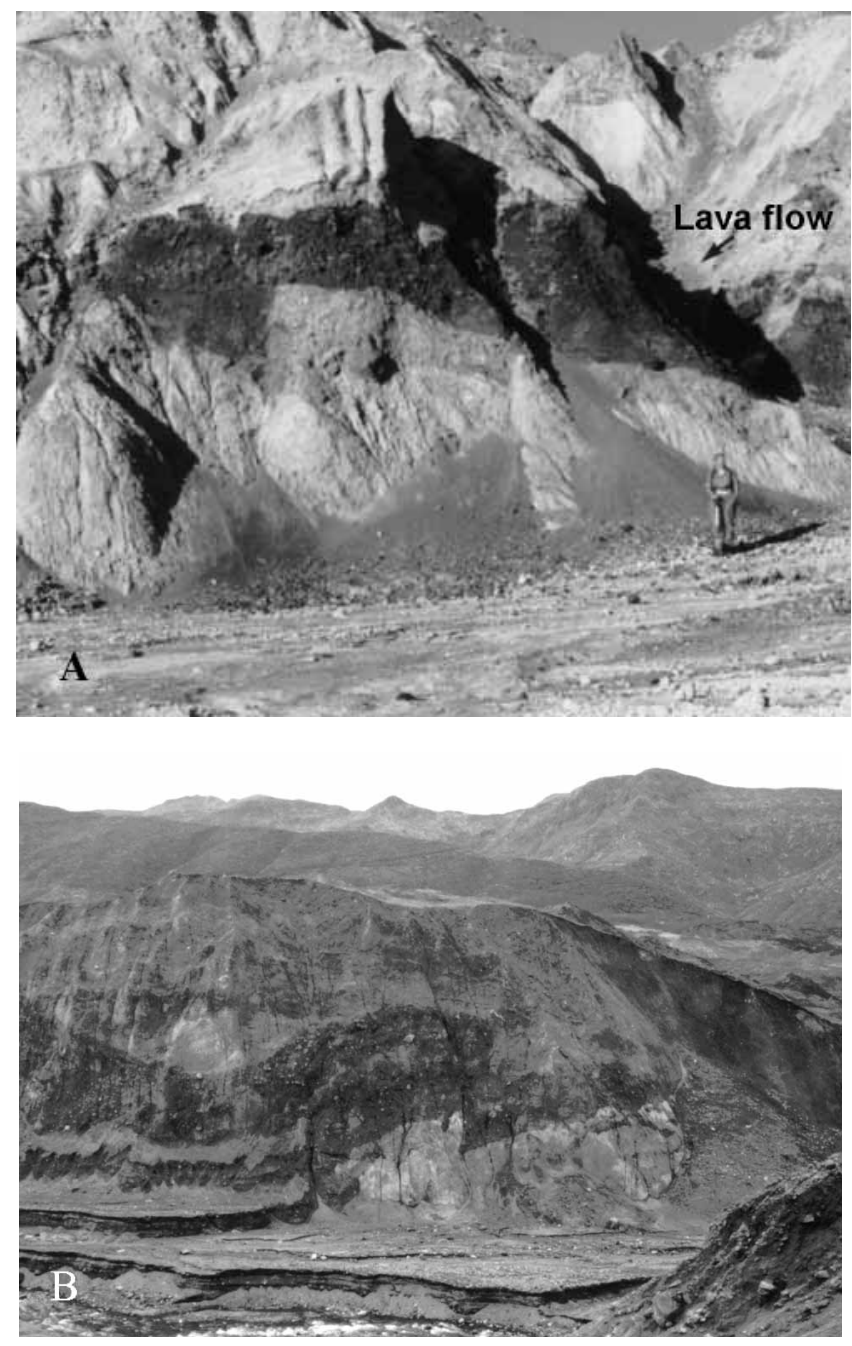

Figure 33. Lava-flow stratigraphy in debris-avalanche deposit. Clasts in lava flows are shattered. A, Exposure about $950 \mathrm{~m}$ west of 825-5 near Spirit Lake, part of "largest block" (see pl. 4), August 1982. B, Exposure in canyon of North Fork Toutle River, about $300 \mathrm{~m}$ north-northwest of DXS-6, October 1984. Canyon is about $25 \mathrm{~m}$ high.

degrees of alteration, likely altered flow tops. More commonly, original volcanic structures and stratigraphy were destroyed during transport of the debris avalanche.

Small amounts of foreign rock types were mixed locally with the andesite and basalt unit. Counts of approximately 100 clasts at selected exposures (table 3) indicate that locally as much as about 40 percent of the material is composed of rock other than andesite and basalt.

\section{MODERN DACITE UNIT}

The modern dacite unit is rubble composed of augite-hornblende-hypersthene dacite derived from the Goat Rocks and Summit domes of the modern $(<2,500$ years old) cone of Mount St. Helens (see "Geology of the Source Area"). It is light gray where fresh and various

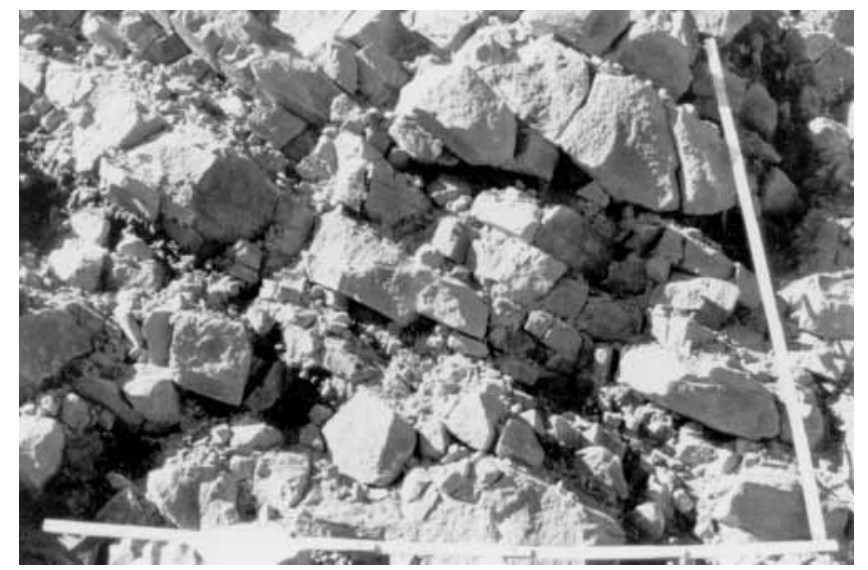

Figure 34. Breakage pattern of modern dacite at $1-\mathrm{m}^{2}$ window DXS-12, likely preserved intact from old mountain.

shades of red and pink where altered. The nearly aphyric dacite contains microphenocrysts of hornblende, pyroxene, and plagioclase. The rock is distinguished from the older dacite by the smaller ( $<2 \mathrm{~mm}$ long) size of the hornblende phenocrysts. Inclusions of various compositions are present locally.

The surface of the modern dacite unit of the debrisavalanche deposit has more clasts $>10 \mathrm{~cm}$ diameter than does the surface of the older dacite unit. This is probably because the ratio of dome rock to volcaniclastic deposits in the modern dacite unit of the old mountain is higher than the same ratio in the older dacite unit of the old mountain.

Locally, breakage patterns that likely represent breakage patterns of original volcanic rocks in the old mountain are exposed in the modern dacite unit (fig. 34). Because there is no remnant of the modern dacite domes exposed in the crater, it is not possible to compare these breakage patterns to original breakage patterns of the material.

\section{MODERN UNDIFFERENTIATED UNIT}

The modern undifferentiated unit contains a mixture of modern dacite, andesite, and basalt. The rock types are the same as those of the modern dacite and the andesite and basalt units.

Minor amounts of older dacite and dacite pumice from the old mountain as well as organic debris are also found in this unit, but proportions are difficult to estimate because of the lack of good exposures. Analysis of four exposures (table 3) shows abundant organic debris but an insignificant amount of rock material that is not modern dacite, andesite, or basalt. 
Table 3. Lithologic counts of approximately 100 clasts $>2 \mathrm{~cm}$ diameter in $1-\mathrm{m}^{2}$ windows

[Sample localities shown on pl. 4. distsr, distance from source; andbas, andesite and basalt; olddac, older dacite; moddac, modern dacite; Ter, Tertiary bedrock; juvnil, juvenile blast dacite; ?, unidentified; pumice, pre-1980 pumice; wood, incorporated organic matter; Sprt, at Spirit Lake; Cstl, at Castle Lake; Cold, at Coldwater Lake; \%, percentage of rock types determined from relative areas of debris-avalanche blocks in windows (fig. 50); (x), percentage of juvenile clasts]

\begin{tabular}{|c|c|c|c|c|c|c|c|c|c|c|}
\hline Sample & $\begin{array}{c}\text { distsr } \\
\text { (km) }\end{array}$ & andbas & olddac & moddac & ter & juvnil & $?$ & pumice & wood & Total \\
\hline \multicolumn{11}{|c|}{ Older dacite unit } \\
\hline DXS-2 & 25.3 & 10 & 81 & 0 & 2 & 0 & 7 & 0 & 0 & 100 \\
\hline DXS -4 & 15.1 & 12 & 90 & 0 & 0 & 0 & 3 & 0 & 0 & 105 \\
\hline DXS-6 & 15.6 & 0 & 100 & 0 & 0 & 0 & 0 & 0 & 0 & 100 \\
\hline DXS-20 & 12.3 & 0 & 100 & 0 & 0 & 0 & 0 & 0 & 0 & 100 \\
\hline DXS-21 & 18.4 & 0 & 100 & 0 & 0 & 0 & 0 & 0 & 0 & 100 \\
\hline DXS-22 & 17.6 & 0 & 100 & 0 & 0 & 0 & 0 & 0 & 0 & 100 \\
\hline DXS-24 & 13.3 & 0 & 100 & 0 & 0 & 0 & 0 & 0 & 0 & 100 \\
\hline 825-3(Sprt) & 9.4 & 12 & 88 & 0 & 0 & 0 & 0 & 0 & 0 & 100 \\
\hline 827-3(Sprt) & 9.7 & 0 & 100 & 0 & 0 & 0 & 0 & 0 & 0 & 100 \\
\hline MS-10(Cold) & 16.9 & 0 & 100 & 0 & 0 & 0 & 0 & 0 & 0 & 100 \\
\hline 826-3(Cold) & 16.4 & 2 & 98 & 2 & 0 & $1(1)$ & 1 & 5 & 0 & 109 \\
\hline \multicolumn{11}{|c|}{ Andesite and basalt unit } \\
\hline DXS-11 & 13.5 & 100 & 0 & 0 & 0 & 0 & 0 & 0 & 0 & 100 \\
\hline DXS-13 & 2.5 & 100 & 0 & 0 & 0 & 0 & 0 & 0 & 0 & 100 \\
\hline DXS-14 & 2.7 & 100 & 0 & 0 & 0 & 0 & 0 & 0 & 0 & 100 \\
\hline DXS-16 & 11.3 & 100 & 0 & 0 & 0 & 0 & 0 & 0 & 0 & 100 \\
\hline DXS-23 & 13.0 & 100 & 0 & 0 & 0 & 0 & 0 & 0 & 0 & 100 \\
\hline DXS-25 & 14.6 & 100 & 0 & 0 & 0 & 0 & 0 & 0 & 0 & 100 \\
\hline DXS-27 & 17.7 & 75 & 2 & 5 & 0 & $1(1)$ & 15 & 0 & 0 & 98 \\
\hline DXS-38 & 29.7 & 98 & 2 & 0 & 0 & 0 & 0 & 0 & 0 & 100 \\
\hline $825-5$ (Sprt) & 9.4 & 100 & 0 & 0 & 0 & 0 & 0 & 0 & 0 & 100 \\
\hline 827-2(Sprt) & 10.6 & 100 & 0 & 0 & 0 & 0 & 0 & 0 & 0 & 100 \\
\hline MS-9(Cold) & 16.9 & 58 & 0 & 42 & 0 & 0 & 0 & 0 & 0 & 100 \\
\hline \multicolumn{11}{|c|}{ Modern dacite unit } \\
\hline DXS-3 & 15.7 & 0 & 0 & 100 & 0 & 0 & 0 & 0 & 0 & 100 \\
\hline DXS-12 & 13.5 & 0 & 0 & 100 & 0 & 0 & 0 & 0 & 0 & 100 \\
\hline DXS-19 & 11.7 & 4 & 0 & 96 & 0 & 0 & 0 & 0 & 0 & 100 \\
\hline MS-1(Cold) & 17.2 & 37 & 17 & 28 & 0 & $13(13)$ & 5 & 0 & 0 & 100 \\
\hline \multicolumn{11}{|c|}{ Modern undifferentiated unit } \\
\hline DXS-17 & 2.4 & 65 & 0 & 35 & 0 & 0 & 0 & 0 & 0 & 100 \\
\hline 826-2(Cstl) & 16.2 & 100 & 0 & 0 & 0 & 0 & 0 & 0 & 0 & 100 \\
\hline $827-6($ Cstl) & 15.9 & 0 & 0 & 77 & 0 & 15 & 0 & 1 & 7 & 100 \\
\hline $827-7($ Cstl $)$ & 15.9 & 22 & 45 & 0 & 0 & 0 & 0 & 0 & 33 & 100 \\
\hline \multicolumn{11}{|c|}{ Mixed block and matrix facies unit } \\
\hline DXS-1 & 29.9 & 41 & 35 & 2 & 0 & 7(7) & 16 & 0 & 0 & 101 \\
\hline DXS- 1 count 2 & 29.9 & 23 & 55 & 1 & 0 & $10(10)$ & 10 & 1 & 0 & 100 \\
\hline DXS- 1 count 3 & 29.9 & 64 & 22 & 1 & 0 & $5(5)$ & 6 & 0 & 0 & 98 \\
\hline DXS-8 & 25.8 & 38 & 52 & 4 & 0 & $5(5)$ & 5 & 0 & 0 & 104 \\
\hline DXS-29 & 21.4 & 33 & 39 & 12 & 0 & $2(2)$ & 15 & 0 & 0 & 101 \\
\hline DXS-30 & 22.2 & 54 & 8 & 7 & 0 & 19(19) & 12 & 1 & 0 & 101 \\
\hline DXS-31 & 23.1 & 33 & 33 & 12 & 0 & $13(13)$ & 9 & 0 & 0 & 100 \\
\hline DXS-33 & 24.5 & 56 & 13 & 9 & 0 & $17(17)$ & 5 & 0 & 0 & 100 \\
\hline DXS-34 & 26.8 & 50 & 51 & 5 & 0 & $2(2)$ & 1 & 0 & 0 & 109 \\
\hline DXS-35 & 28.1 & 19 & 57 & 13 & 0 & $4(4)$ & 5 & 0 & 0 & 98 \\
\hline DXS-36 & 31.2 & 40 & 47 & 5 & 0 & $9(9)$ & 1 & 1 & 0 & 103 \\
\hline DXS-37 & 30.7 & 45 & 39 & 5 & 0 & $3(3)$ & 2 & 3 & 0 & 97 \\
\hline
\end{tabular}


Table 3. Lithologic counts of approximately 100 clasts $>2 \mathrm{~cm}$ diameter in $1-\mathrm{m}^{2}$ windows--Continued

\begin{tabular}{|c|c|c|c|c|c|c|c|c|c|c|}
\hline Sample & $\begin{array}{c}\text { distsr } \\
(\mathrm{km})\end{array}$ & andbas & olddac & moddac & ter & juvnil & $?$ & pumice & wood & Total \\
\hline \multicolumn{11}{|c|}{ Marginal mixed block and matrix facies unit } \\
\hline DXS-9 & 21.7 & 44 & 37 & 7 & 0 & 0 & 11 & 0 & 0 & 99 \\
\hline DXS-28 & 21.0 & 14 & 5 & 4 & 0 & 0 & 2 & 0 & 0 & 25 \\
\hline DXS-32 & 23.6 & 44 & 20 & 30 & 0 & $2(2)$ & 9 & 0 & 0 & 105 \\
\hline DXS-18 & 11.5 & 64 & 1 & 10 & 0 & 9 & 15 & 1 & 0 & 100 \\
\hline DXS-21.5 & 18.0 & 33 & 28 & 2 & 0 & 10 & 26 & 1 & 0 & 100 \\
\hline $826-4(\mathrm{Cstl})$ & 16.6 & 57 & 18 & 2 & 0 & 12 & 24 & 0 & 0 & 113 \\
\hline
\end{tabular}

\section{MIXED BLOCK AND MATRIX FACIES UNIT}

The mixed block and matrix facies unit of the debrisavalanche deposit consists of both matrix facies as well as debris-avalanche blocks of all lithologies from the block facies that are too small to map. These facies and textures are described in greater detail in "Texture of the Deposit". The formation of the unit is discussed in "Texture of the Deposit" and "Conclusions".

Pebble counts of 100 clasts $>2 \mathrm{~cm}$ diameter were carried out at 10 localities of the mixed block and matrix facies unit (table 3 ). The clasts were taken from the $1-\mathrm{m}^{2}$ windows where textures were mapped, samples were taken for grain-size analyses, and field density was measured (see "Texture of the Deposit"). Juvenile "blast" dacite from the cryptodome is present in most of the windows. There is as much as $19 \pm 8$ percent blast dacite (error following the methods of Galehouse, 1971, for 95.4 percent confidence level). The highest quantities of blast dacite are in the exposures that consist entirely of matrix facies; the lowest quantities are in exposures on the margins of the debris avalanche deposit. There is no apparent trend of changing percentages of blast dacite with distance from the volcano (fig. 35).

The mixed block and matrix facies unit occurs primarily in the western part of the debris-avalanche deposit, west of a break-in-slope near the junction of Maratta Creek and the North Fork Toutle River (pl. 4). The break-in-slope (fig. 36) represents the flow front of the "flow of debris-avalanche blocks" of the eastern part of the debris-avalanche deposit. The mixed block and matrix facies unit west of the break-in-slope has a volume of $0.5 \mathrm{~m}^{3}$, or 18 percent of the total volume of the debris-avalanche deposit. It surrounds debris-avalanche blocks of mappable size (>15 m wide).

The levees that bound the western part of the debrisavalanche deposit slope down from the break-in-slope (fig. 37). This configuration suggests that at least some,

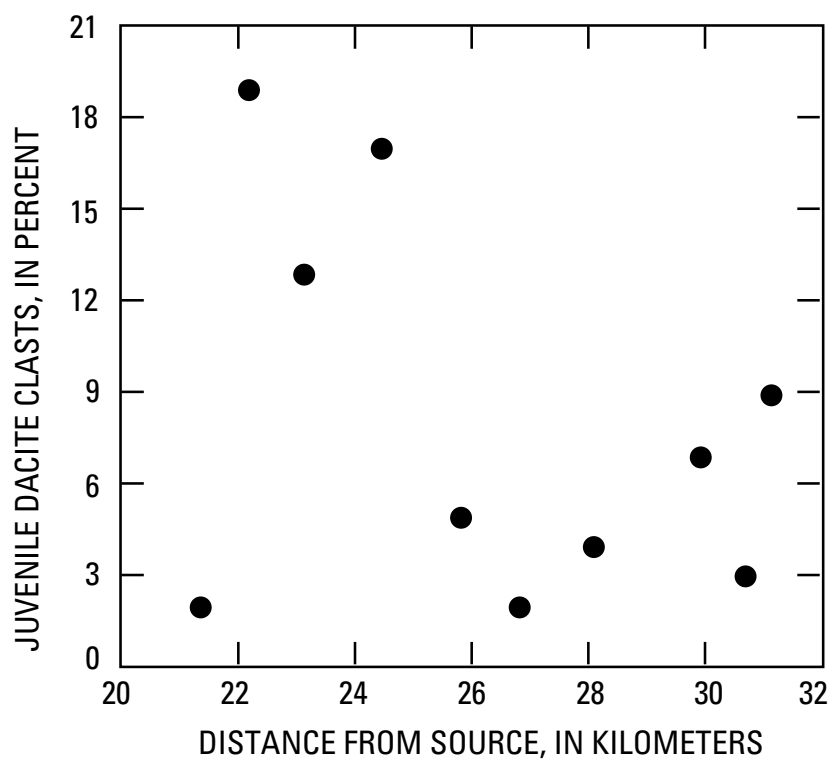

Figure 35. Percentage of clasts of juvenile blast dacite from matrix facies in windows (from table 3 ) versus distance from source (crater). Marginal matrix facies not included.

and probably most, of the material in the mixed block and matrix facies unit was deposited after deposition of the flow of debris-avalanche blocks to the east of the breakin-slope.

A few hummocks of the mixed block and matrix facies unit are mapped in South Coldwater Creek. Fisher and others (1987) call this unit "avalanche II" material; they believe the material originated from slide blocks II and III. In South Coldwater Creek, the matrix facies is continuous from the hummocks to flat-surfaced exposures in interhummock areas where it underlies blast deposits. Some of these flat-surfaced exposures are at least $10 \mathrm{~m}$ thick (Fisher and others, 1987).

East of the break-in-slope in the North Fork Toutle River valley, material interpreted to be matrix facies is found in the deep exposures along Castle Creek and along 


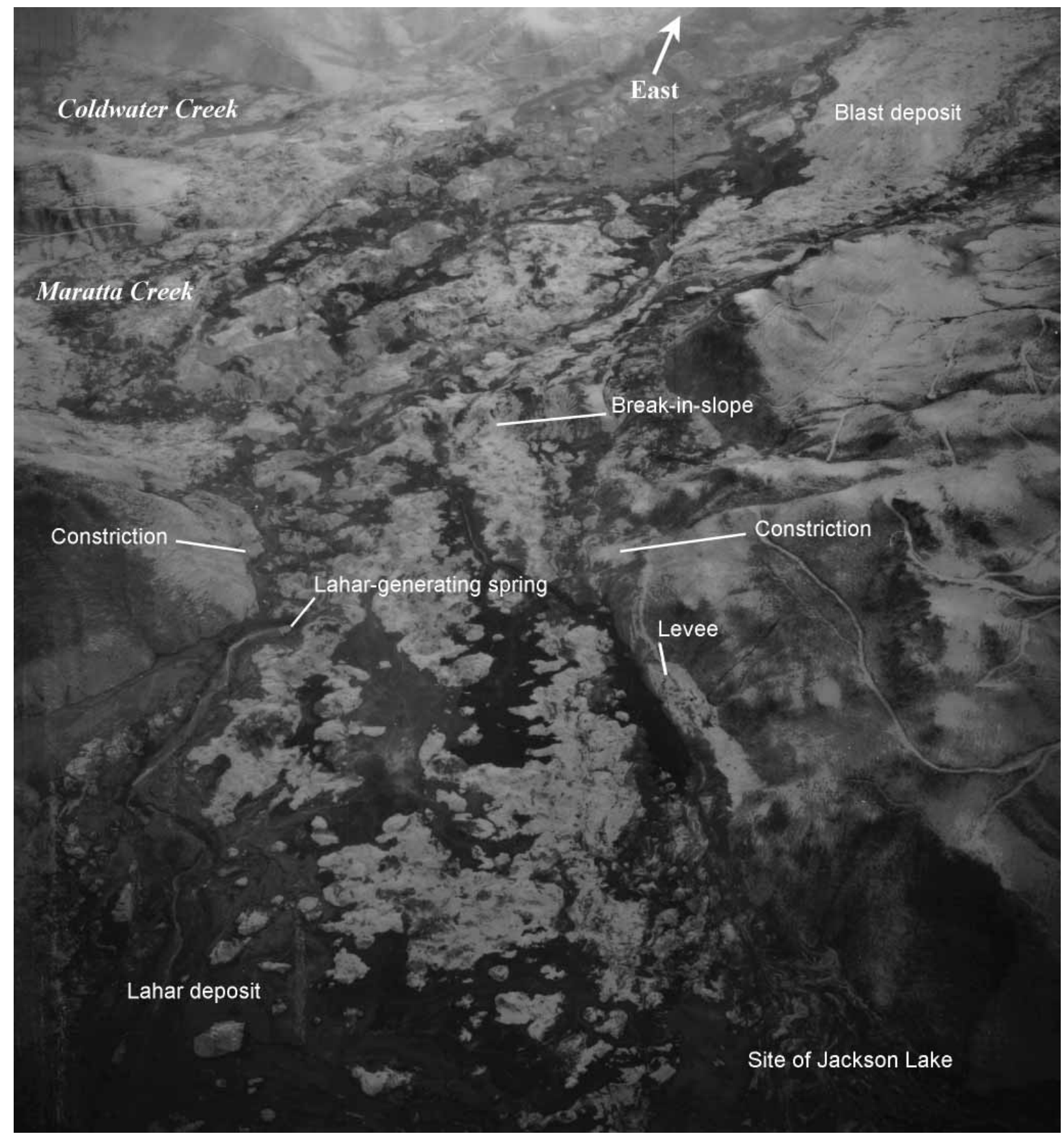

Figure 36. Oblique aerial photograph of debris-avalanche deposit, showing break-in-slope (flow front of flow of debris-avalanche blocks) at constriction just west of Maratta Creek. View to east. Entire debris-avalanche deposit covered by light-colored blast deposit; dark-colored areas are lahar deposits generated after deposition of debris avalanche. Photograph by Austin Post, U.S. Geological Survey, May 19, 1980. Debris-avalanche deposit about $1 \mathrm{~km}$ wide at constriction.

the North Fork Toutle River near Coldwater Creek. Although the matrix facies rests between hummocks, it is not observed to form or to support hummocks within it; instead it overlies material of the block facies, generally the older dacite unit (pl. 5). These matrix facies deposits are likely remnants of the final phase of the debris avalanche that traveled over the top of the deposit of the flow of debris-avalanche blocks (see "Conclusions"). The exposures of matrix facies resemble exposures of the blast deposits that overlie the matrix facies and conceal it on the geologic map.

\section{CONTACTS BETWEEN LITHOLOGIC UNITS}

Though the contacts between lithologic units of the debris-avalanche deposit are sharp locally, they are gen- 


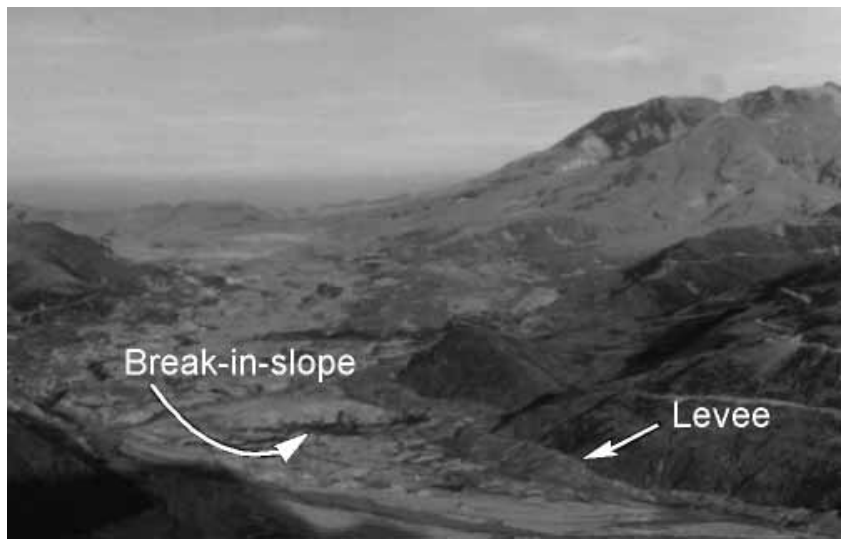

Figure 37. Levees sloping down from break in slope, indicating that much of deposit to west of the break in slope is younger than deposit to east. Debris-avalanche deposit about $1 \mathrm{~km}$ wide at constriction. View to east.

erally diffused over as much as $10 \mathrm{~m}$. The contact between the andesite and basalt unit and the older dacite unit, for example, is especially difficult to define locally because the older dacite in the mountain was intruded by many andesite dikes.

Where they are sharp, the contacts between lithologic units commonly resemble contacts within the present crater. The sharp contact most frequently observed is the andesite and basalt unit overlying the older dacite unit (fig. 38). This contact is very similar to the andesite and basalt/older dacite contact in the crater, and it indicates that the material was transported with little deformation.

\section{OTHER DEPOSITS OF THE MAY 18, 1980, ERUPTION}

\section{BLAST DEPOSITS}

On the morphologic map (pl. 3), blast deposits cover the entire debris avalanche east of the break-in-slope just west of Maratta Creek and are present as a small finger extending west of the break-in-slope. On the lithologic map (pl. 4), blast deposits are mapped only where they were thick enough (approximately $>1 \mathrm{~m}$ ) to conceal the lithology of the debris-avalanche deposit in summer 1982. Since 1980, erosion has washed the blast deposits off most of the hummocks so that blast deposits now mantle primarily interhummock areas. The airfall layer (A3 layer) of the blast deposits mantles the entire debris avalanche (Waitt, 1981; Moore and Sisson, 1981; Sisson, 1995), but because it was only a few centimeters thick, its distribution is not shown on either map. Unmapped blast deposits also blanket the ridges surrounding the debris avalanche.

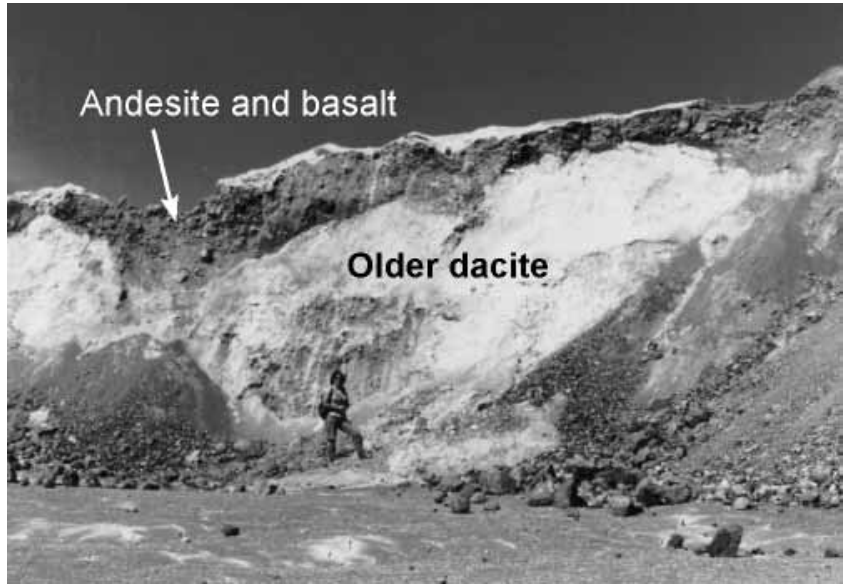

Figure 38. Andesite and basalt unit overlying older dacite unit in debris-avalanche deposit on Johnston Ridge.

The blast deposits in the valley of the North Fork Toutle River, which are generally unsorted and unstratified, contain material ranging from silt-sized particles to boulders meters in diameter. In the area around Spirit Lake, the blast deposits are bedded and better sorted (Glicken and others, 1989), similar to the blast deposits on the ridges surrounding the debris-avalanche deposit.

The blast deposits are recognized by their undulatory surfaces, by the olive-gray color of the finer grained material in the deposit, by the abundance of the juvenile blast dacite, and by local prismatically jointed blast dacite boulders that are as much as $2 \mathrm{~m}$ in diameter on the surface of the deposit (fig. 39). In the first few weeks after the eruption, the blast deposits were also recognized by their temperature, which was much hotter (generally between 100 and $300{ }^{\circ} \mathrm{C}$ ) than the debris-avalanche deposit (highest temperature $98{ }^{\circ} \mathrm{C}$; Banks and Hoblitt, 1981) and by the characteristic smell of rotting wood.

The blast deposits occur locally underneath as well as on top of the debris-avalanche deposit. The base of the debris-avalanche deposit was not well exposed, either in 1980 or in subsequent years; but the blast deposit was positively identified in a few localities at the base of the debris-avalanche deposit. It generally rests on fir needles and other organic debris from the old forest floor (fig. 40), except closer to the mountain where the forest floor was eroded by the debris avalanche (Fisher and others, 1987). Some, but not all, of the trees of the pre-May 18 forest are found prone at the base of the deposit; the rest were pushed in front of the debris avalanche and incorporated in the distal material. The blast deposit may also be present locally within the debris-avalanche deposit near Coldwater Lake, where juvenile dacite was present in some cuttings from holes drilled by the U.S. Army Corps of Engineers in 1981. 

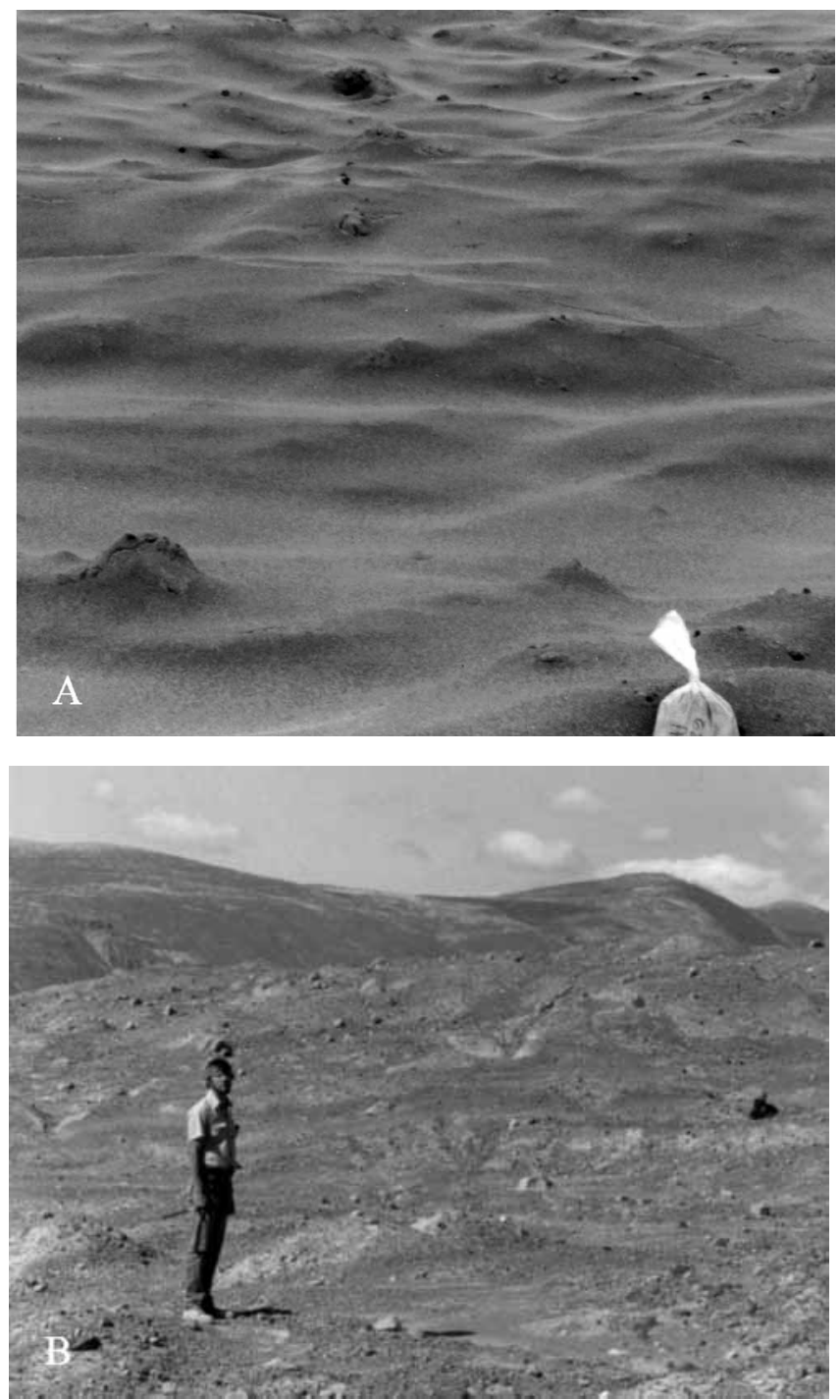

Figure 39. Undulating surface of blast deposit. A, June 1980, before erosion. B, Summer 1982, showing gray boulders of juvenile blast dacite. Blast deposit mantles hummocky topography of debris-avalanche deposit.

The first part (slide block I) of the rockslide-debris avalanche released the pressure on the growing cryptodome that resulted in the blast explosions. The initial blast explosions generated a pyroclastic surge (the "blast surge") that quickly overtook slide block I and knocked down the trees over $600 \mathrm{~km}^{2}$ (Fisher and others, 1987). The blast surge produced the layered stratigraphy described by Hoblitt and others (1981), Moore and Sisson (1981), and Fisher and others (1987). Although it is difficult to find good exposures of the base of the debrisavalanche deposit, debris-avalanche deposit overlies trees felled by the blast, leaving no doubt that the erosive phase of the blast surge in places preceded deposition of the debris-avalanche deposit. The fact that the debris-avalanche deposit rests on top of some of the blast deposit on

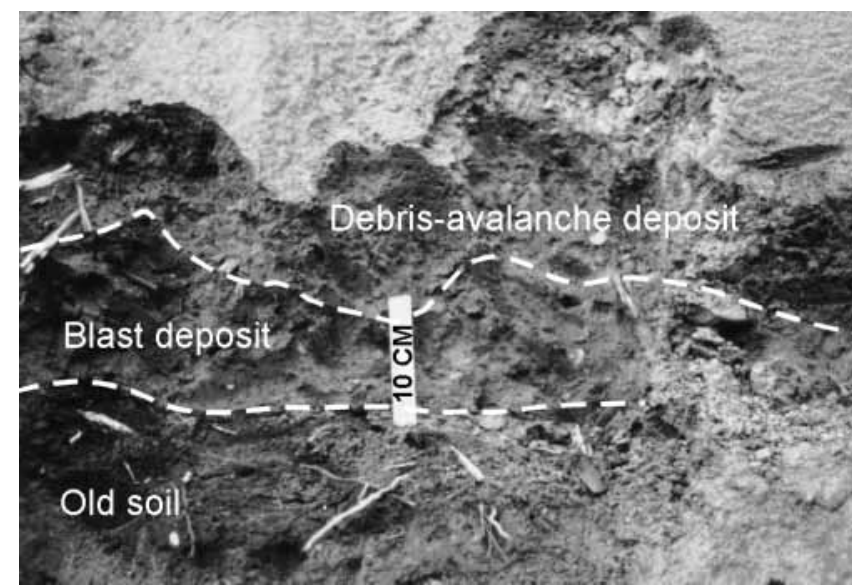

Figure 40. Blast deposit resting on fir needles and organic material from old forest floor and overlain by debris-avalanche deposit in excavation for spillway draining Coldwater Lake. June 1980 exposure about $100 \mathrm{~m}$ east of sample locality DXS-38.

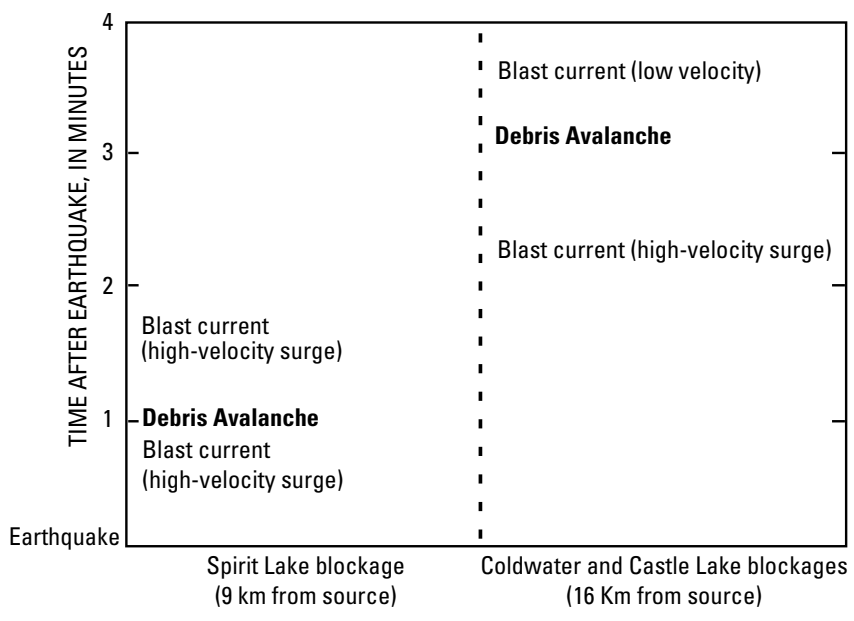

Figure 41. Timing of deposition of debris avalanche and blast currents in area of Spirit and Coldwater Lakes. Timing of events from Voight (1981), Voight and others (1983), and Moore and Rice (1984).

the south slope of Johnston Ridge indicates that deposition of the debris avalanche followed some of the blast surge within $10 \mathrm{~km}$ of the mountain. However, the correlation of the layered stratigraphy of the blast that rests on top of the debris avalanche near Spirit Lake with the stratigraphy of the blast surge in South Coldwater Creek (Glicken and others, 1989) indicates that, within $10 \mathrm{~km}$ of the mountain, most of the deposition of the blast surge followed the deposition of the debris avalanche (fig. 41).

As shown on the morphologic map (pl. 3), blast deposits (before erosion) blanketed the entire debris-avalanche deposit east of the break-in-slope just west of Maratta Creek, and a small finger of blast deposits extended to the west of the break-in-slope. This map unit 


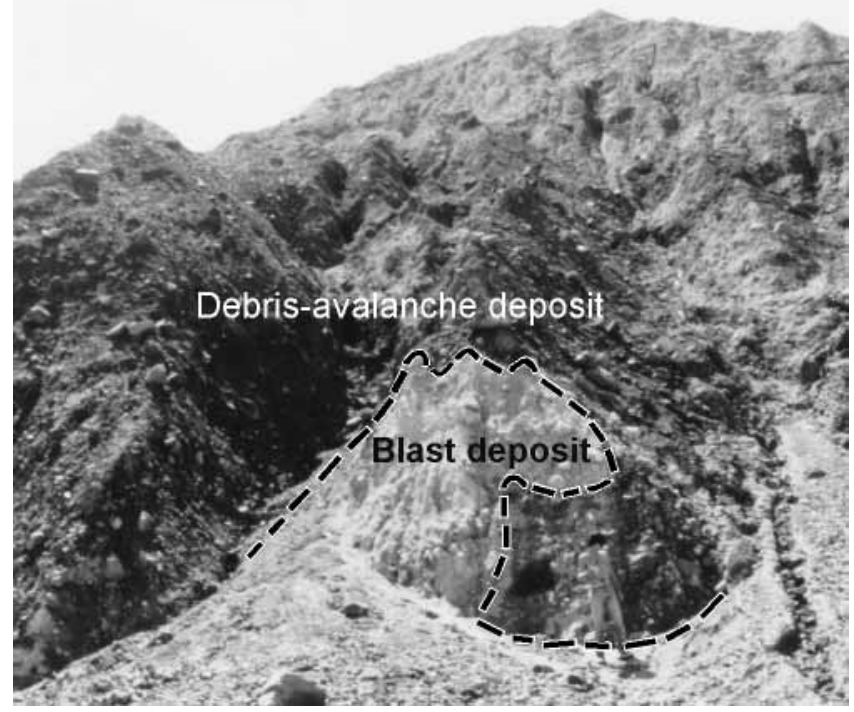

Figure 42. Intimate interconvolution of debris-avalanche and blast deposits. Exposure located about $50 \mathrm{~m}$ southeast of DXS-19.

was deposited by many pyroclastic currents that have left many overlapping deposits.

The blast deposit unit covers debris-avalanche material that was deposited at different times; this arrangement suggests that most of the pyroclastic currents from the blast were deposited after deposition of the debrisavalanche deposit. However, exposures showing debrisavalanche blocks intimately interconvoluted with the blast deposit (fig. 42) indicate that, locally, some of the pyroclastic currents of the blast may have been transported to their place of deposition "piggybacked" on top of the debris-avalanche deposit (R.B. Waitt, written commun., 1985). But the lobate and dune forms that made up the wavy surface of the blast deposit before erosion (figs. 18,39 , and 43), as well as the common morphologic relations of the blast deposit to the hummocks of the debrisavalanche deposit (figs. 18, 36, 39B, and 43), would have been destroyed by "piggybacking." This relation further suggests that most of the pyroclastic currents from the blast were deposited after deposition of the debris-avalanche deposit.

The blast deposits on top of the debris-avalanche deposit mantle hummocks but are thicker in depressions (figs. 18 and 36); these relations to topography are characteristic of pyroclastic surges (Wright and others, 1980). However, the blast deposits are generally massive, and in the more distal regions are restricted only to interhummock areas, which are features characteristic of dense pyroclastic flows sensu stricto (Wright and others, 1980). The blast deposits that emptied the magma chamber after deposition of the avalanche deposit were likely emplaced by pyroclastic density currents that were both surges and flows; but in any case, the currents must have been much less inflated than the initial "blast surge" that surmounted 1,000-m-high ridges and left well-stratified deposits.

Both the blast deposit and the matrix facies of the debris-avalanche deposit are a homogeneous mix of all rock types from the old mountain and the juvenile blast dacite, and they are commonly difficult to distinguish from each other. However, the surface morphology of the deposits is visible because the matrix facies of blast deposit where it covers the debris-avalanche deposit has a distinctive undulating surface morphology that is commonly studded with boulders of blast dacite (fig. 39), compared with the hummocky morphology of the matrix

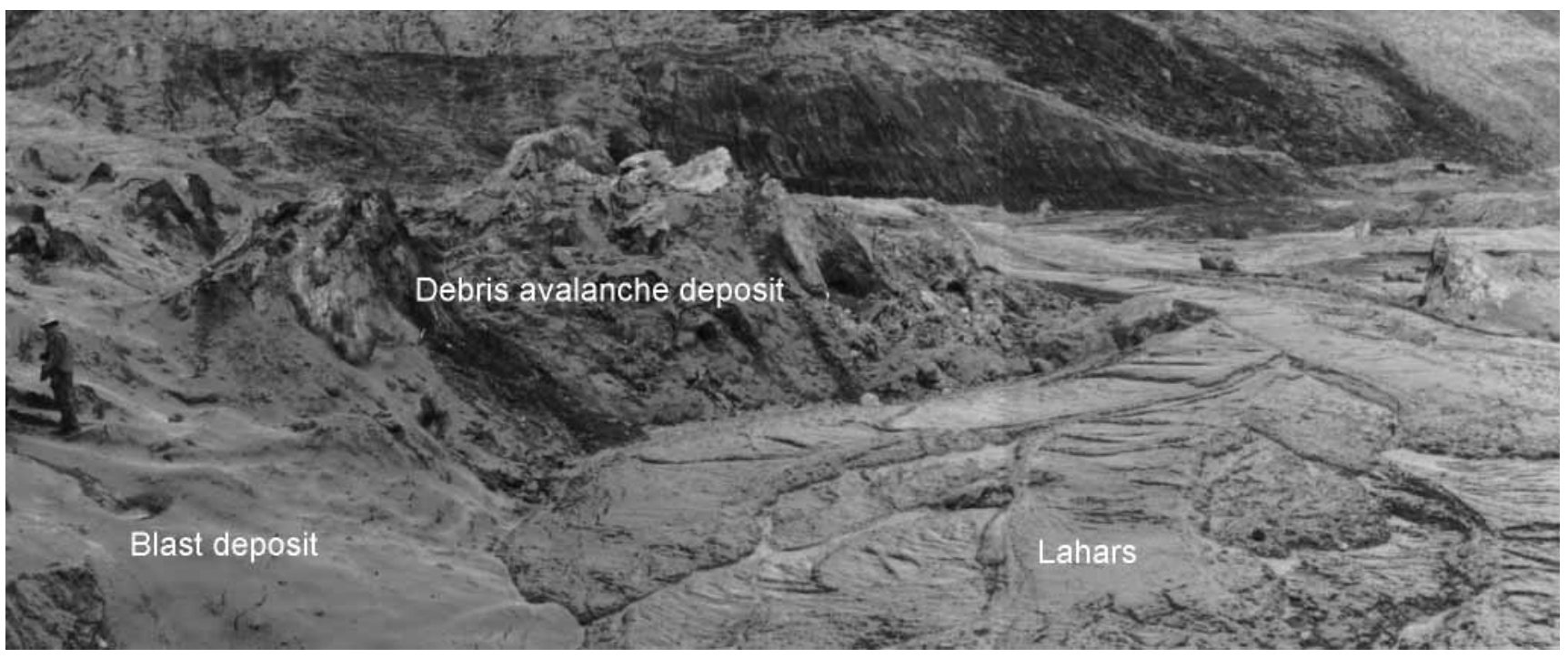

Figure 43. Ropy surface of lahar deposit overlying blast deposit, which overlies debris-avalanche deposit. Photograph taken June 22, 1980. 
facies of the debris-avalanche deposit. The blast deposit generally contains a larger percentage of juvenile blast dacite than the debris avalanche. In South Coldwater Creek, the matrix facies is readily distinguished from the blast deposits mapped adjacent to the hummocks because the matrix facies contains a high percentage of organic material, soil, prehistorically erupted tephra, and bedrock picked up from surrounding rocks on Johnston Ridge (Fisher and others, 1987).

Blast deposits mapped here can be correlated only with the composite A1 unit of Waitt (1981); this unit includes a layer of pebble gravel with or without sandy finer grained material. Except in the area near Spirit Lake (see Glicken and others, 1989), the blast deposit on top of the debris avalanche cannot be correlated with the units defined by Hoblitt and others (1981), Moore and Sisson (1981), or Fisher and others (1987). The units of the other authors, which were defined on the ridgetops around Mount St. Helens and in South Coldwater Creek, consist of a coarse, friable, fines-depleted lower layer overlain by a layer with more fine ash and parallel to wavy laminations.

\section{LAHAR DEPOSITS}

On the morphologic map (pl. 3), lahar deposits are shown where they cover most of the surface area of the debris-avalanche deposit and also where they flowed off the west end of the avalanche deposit. Within areas mapped as lahar deposits, there are many isolated hummocks not covered with lahars that could not be shown on the scale of the morphologic map.

On the lithologic map, lahar deposits covering the debris-avalanche deposits are mapped only where they are thick enough (approximately $>1 \mathrm{~m}$ ) to prohibit identification of the lithology of the underlying debris-avalanche deposit. Lahar deposits thinly mantle the debrisavalanche deposit in many other areas. Lahars are also mapped on the lithologic map where they flowed off the west end of the debris-avalanche deposit.

The lahar deposits consist of mudflow, debris flow, and hyperconcentrated lahar-runout deposits (terminology of Pierson and Scott, 1985) that formed from the debris avalanche in the late morning and early afternoon of May 18 (Janda and others, 1981). "Lahar" is the appropriate term here, as it is an inclusive term that describes masses of flowing volcanic debris intimately mixed with water (Fisher and Schmincke, 1984). Voight and others $(1981,1983)$ and Lipman (1981) referred to the same deposits as "mudflow" units.

The lahar deposits have a generally flat but locally ropy surface morphology (fig. 43). They never form hummocks and, where present, cover the debris-avalanche deposit in the areas between hummocks.

The texture of the lahar deposits is generally distinct from that of the debris-avalanche deposits. They consist of clasts that are as much as tens of centimeters in diameter dispersed in brown finer grained material; they do not contain debris-avalanche blocks transported intact from the old mountain.

During the afternoon of May 18, 1980, while traveling up and down the North Fork Toutle River in a helicopter on a rescue mission, I observed some of the lahars forming from slumping of water-saturated debris avalanche material (fig. 44A). The moving lahars often ponded between hummocks and broke out to form lahars with greater peak discharges. Just after the eruption, some hummocks showed slump features that had clearly generated lahars (fig. 45). Some lahars also formed from headward erosion of channels in the debris avalanche that I saw full of mud on May 18 (fig. 44B). Some formed from incorporation of sediment by stream flows that emanated from springs in the debris-avalanche deposit. The spring that generated the most lahars is at the base of the break-in-slope just west of Maratta Creek (fig. 36). R.P. Hoblitt (oral commun., 1982) observed water to gush from the spring on the afternoon of May 18.

Although the debris avalanche was emplaced shortly after 8:32 a.m. Pacific Daylight Time (P.D.T), the major lahar did not flow off the west end of the avalanche deposit until the afternoon of May 18. I arrived in the North Toutle River valley at 12:18 p.m. and saw the river channel west of the debris-avalanche deposit, but I did not see flowing lahars. The peak stage of lahar generation was at about 1:30 p.m. in the Elk Rock area (Cummans, 1981). Slumping of a significant volume of material and the development of a ground water flow field to form springs apparently required a few hours; also, melting ice may have contributed water to generate lahars, and it probably took a few hours for enough ice to melt (Fairchild, 1985, 1987). Harmonic tremor related to the intense eruptive activity in the afternoon may also have contributed to the generation of lahars (Fairchild, 1985, 1987).

At 12:18 p.m., I saw a coating of mud about $1 \mathrm{~cm}$ thick on boulders in the channel just west of the distal end of the debris-avalanche deposit. The coating extended no more than $0.5 \mathrm{~m}$ above the surface of the channel; it probably was deposited by muddy Toutle River water pushed in front of the avalanche. 


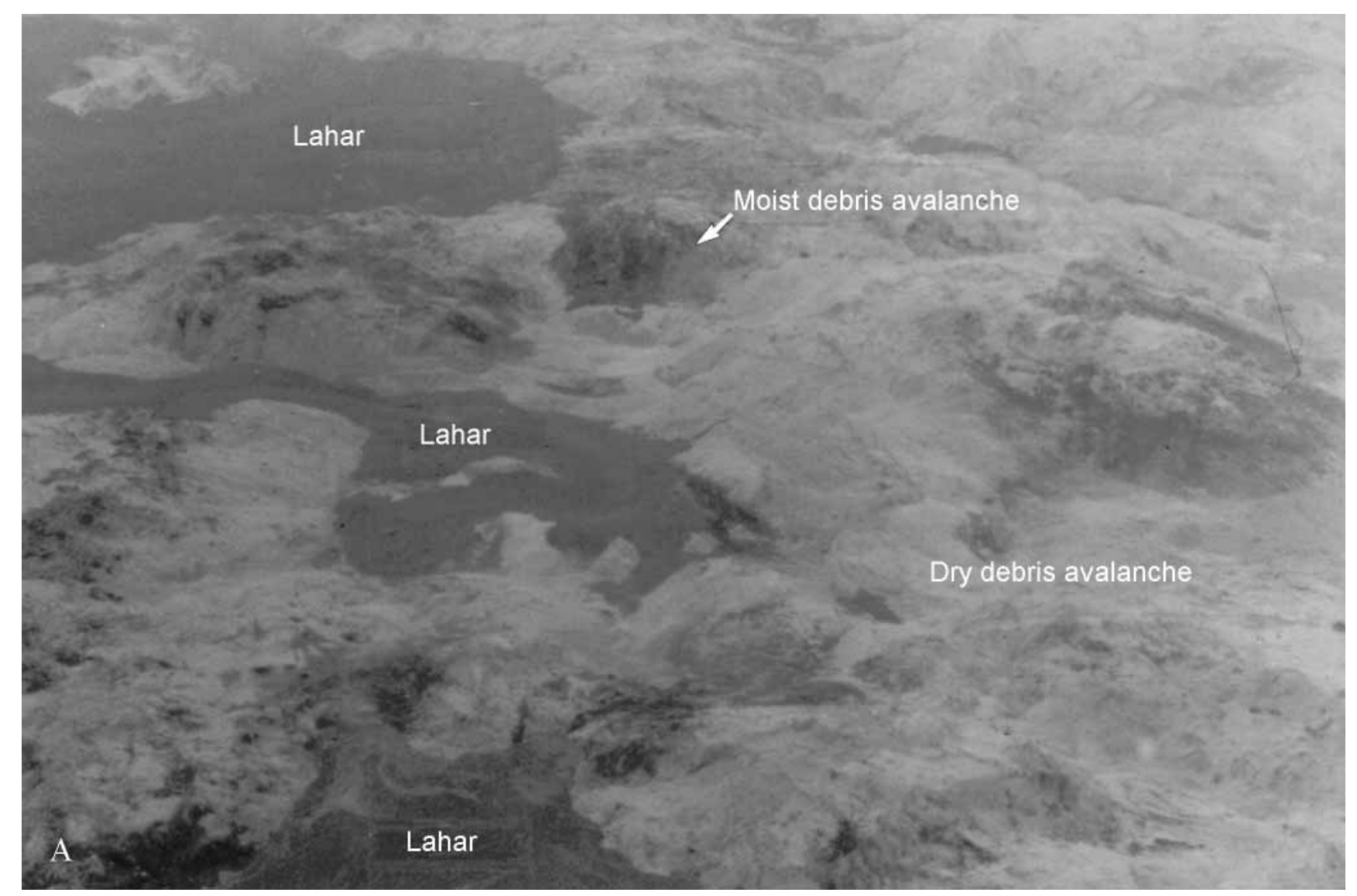

Figure 44. Oblique aerial photographs of moving lahars near North Fork Toutle River on afternoon of May 18, 1980. A, Dark-colored moving lahars that formed from slumping of water-saturated hummocks. Light-colored hummocks are dry debris-avalanche deposit. Dark-colored hummocks are moist debris-avalanche deposit showing incipient lahars. Scale uncertain, probably about $150 \mathrm{~m}$ wide (Continued on next page).

\section{PYROCLASTIC-FLOW DEPOSITS OF THE AFTERNOON OF MAY 18}

Pumiceous pyroclastic-flow deposits rest on top of the debris-avalanche and blast deposits in the area just north of the crater. They cover the debris-avalanche deposit to depths of more than $40 \mathrm{~m}$ and have a volume of about $0.25 \mathrm{~km}^{3}$ (C.W. Criswell, oral commun., 1984).

The pumiceous pyroclastic-flow deposits are easy to distinguish from the debris-avalanche and the blast deposits. They consist of highly inflated pumice (mostly white to yellow, with some gray fragments) and subordinate lithic debris in glassy, finer grained material. Nearly all the deposits have levees and flow fronts consisting of the coarser grained parts of the deposits (Rowley and others, 1981; Criswell, 1984).

These deposits formed from the continued emptying of the May 18 magma chamber after the initial avalanche and blast events. For the entire morning, the magma produced only a vertical column, but in the afternoon both a vertical column and pyroclastic-flow deposits were produced (Christiansen and Peterson, 1981; Criswell, 1987).

\section{TERTIARY BEDROCK}

The ridges surrounding the debris-avalanche deposit are composed of well-lithified Tertiary bedrock. These rocks are primarily flows and breccias of basaltic to rhyolitic composition that have been regionally metamorphosed to zeolite or prehnite-pumpellyite facies. Around Spirit Lake, there are some small areas of granitic rocks of the 21- to 22-m.y.-old Spirit Lake pluton (Evarts and others, 1987). The volcanic rocks were correlated with the Oligocene-Miocene Ohanapecosh Formation, which was dated at 31-45 m.y. outside the map area (Hammond, 1980).

Recent work by Evarts and others (1987) casts doubt upon this correlation. The bedrock around Mount St. Helens contains only rare exposures of epiclastic volcanic 


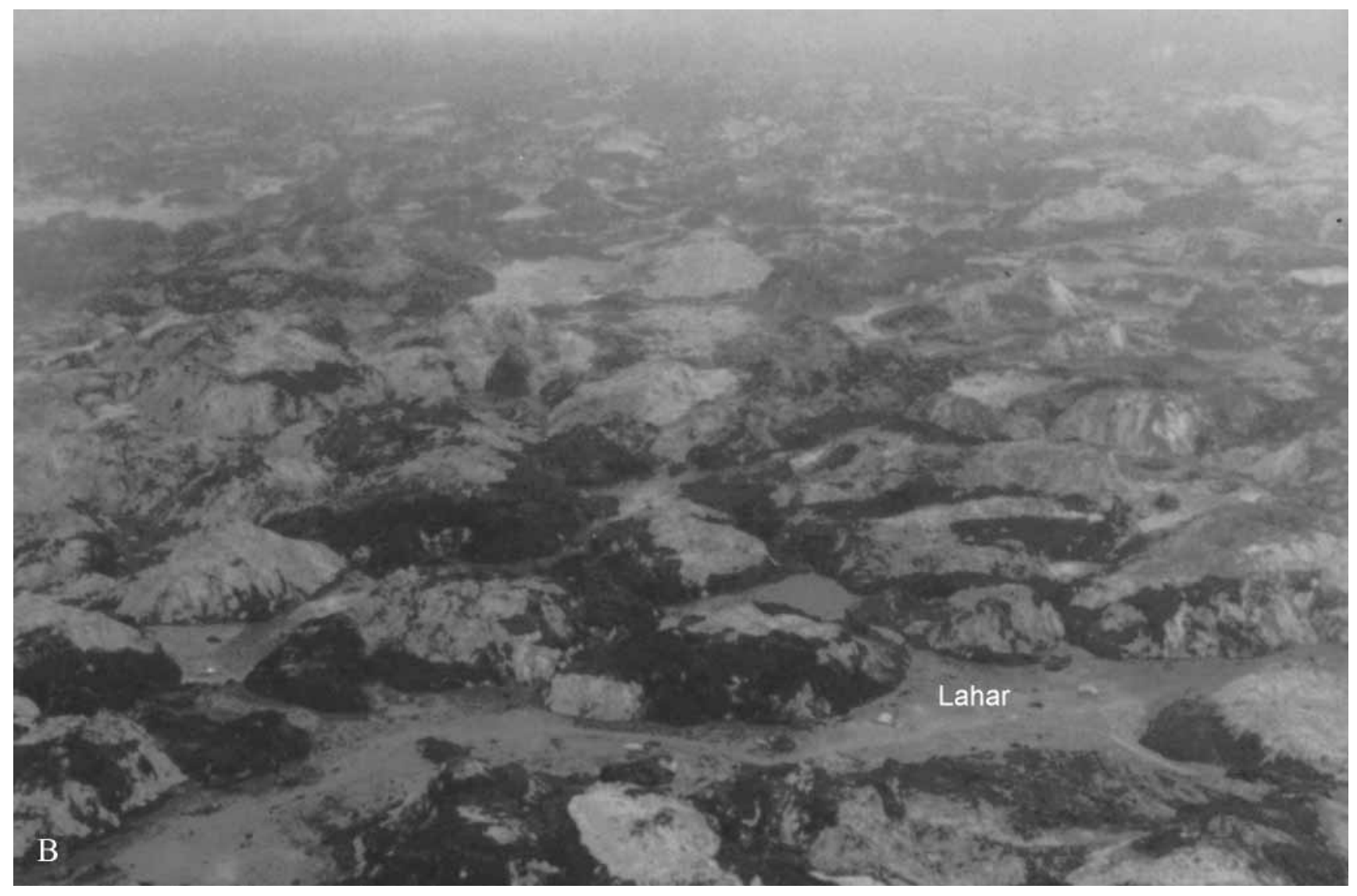

Figure 44. Oblique aerial photographs of moving lahars near North Fork Toutle River on afternoon of May 18, 1980. B, Channels full of lahar near distal end of debris-avalanche deposit. Light-colored hummocks are dry debris-avalanche deposit; dark-colored hummocks are moist debris-avalanche deposit. Scale uncertain, probably about $50 \mathrm{~m}$ wide.

rocks that are common in the type area of Ohanapecosh in Mount Rainier National Park (Fiske and others, 1963). Moreover, potassium-argon dating of the rocks in the Spirit Lake quadrangle just north of Mount St. Helens showed that the rocks were 22 to 28 m.y. old (Russell Evarts, oral commun., 1985), considerably younger than the ages of the Ohanapecosh Formation. Following the example of Evarts and others (1987), no formation name is used for these rocks; they are simply called "Tertiary bedrock."

\section{TEXTURE OF THE DEPOSIT}

\section{GENERAL STATEMENT}

\section{TERMINOLOGY}

The terminology of sedimentology contains many terms that are ambiguous when applied to debris-avalanche deposits. In order to study debris-avalanche deposits, it is necessary to rigorously define and consistently use a single set of definitions. Some of this termi- nology is drawn from the literature of sedimentology, some is drawn from the literature on volcaniclastic rocks, and some is adapted from previously published studies of large volcanic debris-avalanche deposits. The usage of some terms in this work is summarized in the glossary.

The texture of volcaniclastic deposits commonly refers to the grain-size distribution of the material (for example, Crandell, 1971, Murai, 1961). Here, it is used in the more general sense (for example, Fisher and Schmincke, 1984) to refer to the size, shape, and fabric (pattern of arrangement) of the particles that form the deposit. A "particle" is usually considered to be a "separable or distinct unit in a rock" (Bates and Jackson, 1980).

The word "structure" is applied to features visible on the scale of exposures (for example, Fisher and Heiken, 1982). The distinction between textures and structures is somewhat arbitrary because exposure-scale features also represent the pattern of arrangement of particles. "Texture" is used in this work to refer to these patterns on any scale. 


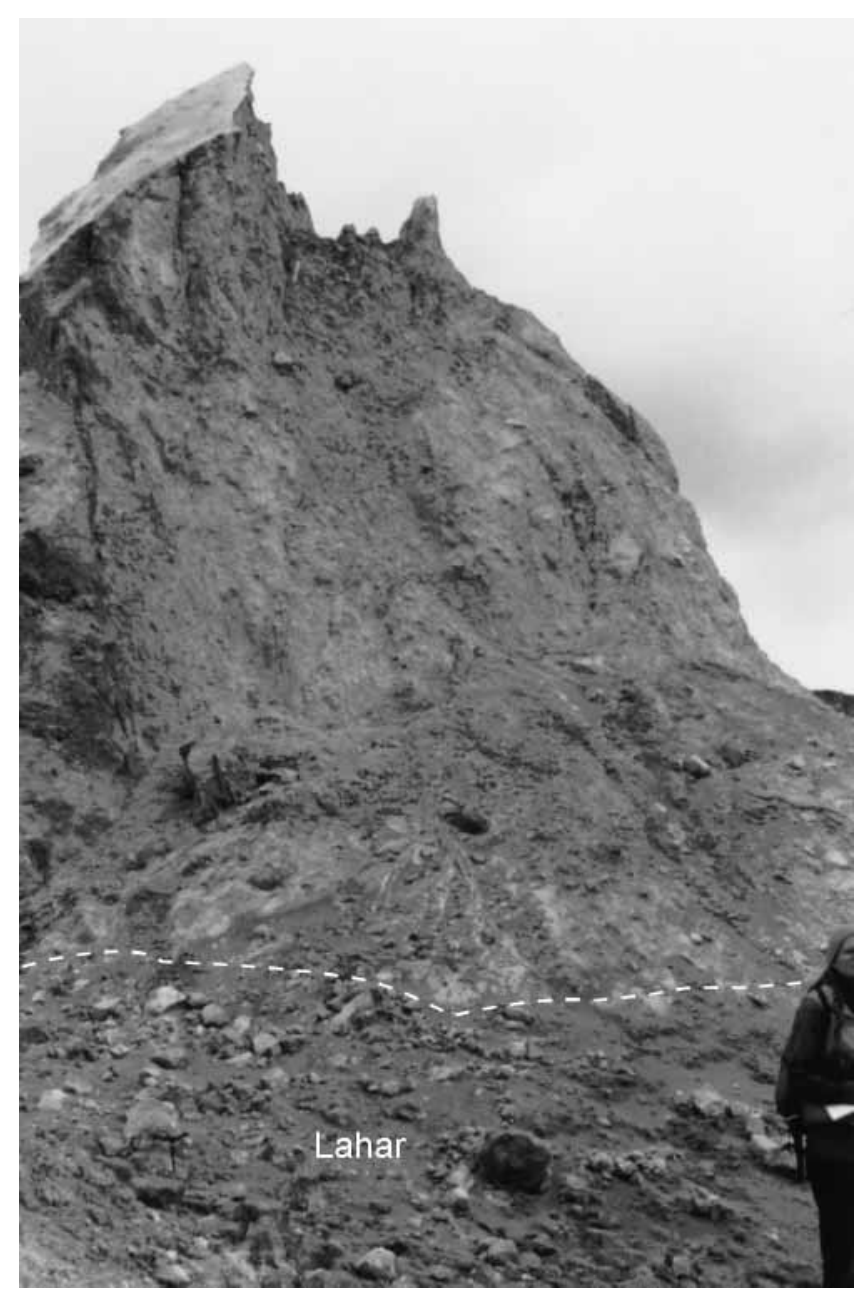

Figure 45. Scarp of a slump on a debris-avalanche hummock that produced a lahar. Photograph from June 22, 1980.

Two different kinds of particles are defined to describe the debris-avalanche deposit. A "clast" is defined as a rock of any size that would not break if passed through a sieve or immersed in water. Each clast can be considered one particle. A "debris-avalanche block" is defined as a coherent, unconsolidated or poorly consolidated piece of the old mountain that was transported to its place of deposition relatively intact. Each debris-avalanche block may be thought of as one particle that contains many smaller particles (clasts). The usage of the term "debris-avalanche block" is similar to that of "megablock" of Mimura and Kawachi (1981) and Ui (1983). The distinction between consolidated clasts and unconsolidated or poorly consolidated debris-avalanche blocks is essential for the analysis of exposures.

Several terms are used in this chapter to describe the disintegration of material. The breaking of individual clasts is "fracturing." Thorough fracturing of clasts is called "shattering." When material expands from its orig- inal density on the mountain (at least in part by shattering of clasts), it is said to "dilate"; when it breaks apart into its constituent clasts which then move apart, it "disaggregates."

Two end-member facies are used to describe the texture of the debris avalanche, the block facies and the matrix facies. This terminology follows the precedent of Crandell and others (1984), and Ui and Glicken (1986). Both facies would be classically described as angular, unstratified, unsorted rubble consisting of material (clasts) that ranges in size from microns to meters in diameter.

The block facies consists entirely of debris-avalanche blocks, coherent unconsolidated or poorly consolidated pieces of the old mountain that were transported relatively intact. Debris-avalanche blocks range in size from a few centimeters to more than a hundred meters wide. Some of the debris-avalanche blocks are smeared out and deformed to varying degrees. The smeared-out debrisavalanche blocks a few centimeters wide that are commonly observed in exposures are called "rubble schlieren."

Most of the clasts in the block facies were partially or completely shattered from their origin on the old Mount St. Helens, so that although the original stratigraphy or structure is locally preserved (the "mutual arrangement of separate fragments"; Gorshkov and Dubik, 1970) few clasts meters wide from the old mountain remain. Shreve (1968) observed the same texture in the nonvolcanic Blackhawk slide and named it the "three-dimensional jigsaw puzzle effect." In the Mount St. Helens deposit, the shattering has produced unconsolidated rubble or poorly consolidated rubble that was cohesive enough upon deposition to form hummocks.

The term matrix facies is used here in the sense of Crandell and others (1984) and Ui (1983) to refer to the completely mixed parts of the debris-avalanche deposit. The matrix facies contains all rock types from the old mountain and juvenile "blast" dacite in an unsorted and unstratified mixture. Locally, fragments of wood and bits of soil and rock from the terrain underlying the deposit are present in the matrix facies.

It must be emphasized that "matrix" is not used as a grain-size designation in this study. Other authors, (for example, Horz and others, 1983; Crandell, 1971) in their studies of unsorted or poorly sorted clastic deposits, use "matrix" to refer to finer grained parts of the deposits, but the "matrix facies" of large volcanic debris avalanches can contain clasts that range in size from microns to meters in diameter (Crandell and others, 1984; Ui, 1983). 


\section{SCALES OF STUDY}

The texture of the avalanche was studied on many different scales. The lithologic map of the deposit (pl. 4) is a map of areas that represent different rock types and areas that include matrix facies and debris-avalanche blocks too small to map. The map shows relations between the block facies and the matrix facies on the largest scale, and it can be interpreted to indicate relations between different debris-avalanche blocks of the block facies. Maps of 1- $\mathrm{m}^{2}$ exposures cleared of colluvium and slope debris (called "windows") show these relations as well as the relations between individual clasts. Grain-size analyses give the size distributions of clasts in the $1-\mathrm{m}^{2}$ exposures.

\section{TEXTURAL INTERPRETATION OF MAP RELATIONS}

The lithologic map of the debris avalanche (pl. 4) shows two principal divisions of the avalanche deposit. In the eastern part of the North Fork Toutle River valley (east of the prominent break-in-slope at the constriction just west of Maratta Creek; fig. 36), the only units of the debris avalanche that are mapped are units of the block facies, although isolated exposures of matrix facies are found covered with blast deposit (pl. 5). This part of the debris-avalanche deposit is referred to as the "flow of debris-avalanche blocks," and the break-in-slope is the flow front of the flow of debris-avalanche blocks. West of this break-in-slope and in South Coldwater Creek, only isolated areas of the block facies are mapped; the rest are the mixed block and matrix facies unit. Stratigraphic evidence (see "Geologic Maps of the Deposit"; fig. 37) indicates that most of the debris avalanche west of the break-in-slope was deposited after deposition of most of the eastern part of the debris-avalanche deposit, and it is part of the deposit from slide block III (see "Conclusions").

\section{EAST OF THE BREAK-IN-SLOPE}

Each area of one lithologic unit of the debris-avalanche deposit in the eastern part of the North Fork Toutle River valley is composed of one or more blocks. Rarely, block boundaries can be delineated by comparing the stratigraphy or structures in the blocks to those in the old mountain (for example, figs. 13A and 33). However, because block boundaries do not necessarily coincide with mapped lithologic contacts, map patterns cannot be interpreted as patterns of blocks.

The area near Spirit Lake contains the largest, least deformed debris-avalanche blocks found in the debris- avalanche deposit. A debris-avalanche block was identified that has a minimum exposed area of $1.5 \times 10^{5} \mathrm{~m}^{2}$ and a volume of $1.7 \times 10^{7} \mathrm{~m}^{3}$ (fig. $13 \mathrm{~A}$ ); the minimum extent of the block is outlined with a dashed line on plate 4 . A contact between the older dacite unit and the andesite and basalt unit that extends from hummock to hummock across five hummocks defines the debris-avalanche block, because it indicates that one piece of the old mountain was transported relatively intact. The same contact occurs throughout the area west of Spirit Lake and east of the Pumice Pond (called "Spirit Lake Blockage" by Glicken and others, 1989) so it is possible that this entire area may be one debris-avalanche block. The contact is faulted down between the hummocks (fig. 13A). This fact suggests that the morphology of the area reflects normal faulting produced by extension and that the hummocks are horsts and the interhummock areas are grabens (hummock formation mechanism 1, see "Geometry of the Deposit").

Areas along the margins of the debris-avalanche deposit (on the north side between Coldwater Lake and Spirit Lake, and on the south side between Castle Lake and Studebaker Ridge) have a chaotic lithologic pattern. The rock types in these areas are primarily modern dacite, andesite, and basalt, with relatively little older dacite. The rock types are jumbled together, and hummocks commonly consist of more than one rock type. A few structures showing igneous dikes or layering resemble structures in the crater (fig. 46). Hummocks with these structures are identified as "coherent" and designated as a separate unit on plate 4 . These are the only areas where it is possible to identify debris-avalanche block boundaries. The largest debris-avalanche block identified in these marginal areas has an exposed area of $1.8 \times 10^{4} \mathrm{~m}^{2}$ and an estimated volume of $1.3 \times 10^{6} \mathrm{~m}^{3}$.

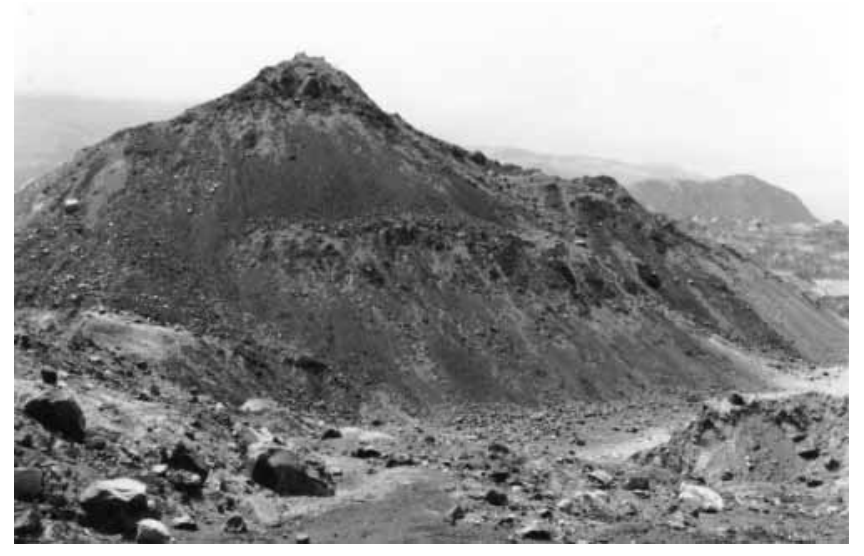

Figure 46. Hummock made of one debris-avalanche block in andesite and basalt unit near Coldwater Lake. Layered lava-flow stratigraphy preserved from crater. Hummock about $60 \mathrm{~m}$ high. 
The chaotic distribution of map units probably results from the interaction of the moving avalanche with the underlying terrain. Debris-avalanche blocks were highly deformed when they smashed against the ridges. Debris-avalanche blocks slowed down on the margins of the North Fork Toutle River valley and then broke up and tumbled end-over-end when they came in contact with the irregularities of the underlying topography. This interaction is also reflected in the morphology of the deposit in the marginal areas, where the morphology is much more irregular than the morphology in the central areas.

Although only debris-avalanche blocks are mapped in the North Fork Toutle River valley east of the break-inslope, material interpreted to be matrix facies is present in the deep exposures of Castle Creek and the North Fork Toutle River near Coldwater Creek (pl. 5, $D-D^{\prime}$ ). This material closely resembles the overlying blast deposits that conceal the matrix facies on the geologic map (pl. 4). In this area, the matrix facies occurs between hummocks but is not observed to form or support them. The material is interpreted to be matrix facies because it has low percentages of juvenile dacite clasts $>2 \mathrm{~cm}$ wide $(9 \pm 6$ percent at an exposure $60 \mathrm{~m}$ north of sample locality DXS-6, compared with $25 \pm 11$ percent for the blast deposit directly overlying it) and is $>10 \mathrm{~m}$ thick, considerably thicker than the blast deposit.

A few hummocks of the mixed block and matrix facies unit are mapped in South Coldwater Creek. These hummocks are almost entirely matrix facies. Fisher and others (1987) refer to the matrix facies in South Coldwater Creek as "avalanche II" material; they interpreted the material as having originated as slide blocks II and III. This terminology is not used here because it does not apply to the main part of the debris-avalanche deposit.

\section{WEST OF THE BREAK-IN-SLOPE}

The map pattern of the debris-avalanche deposit west of the break-in-slope near Maratta Creek is very different from that of the eastern part of the avalanche. Debrisavalanche blocks as much as a few tens of meters wide occur only locally, because most of the deposit consists of a mixture of matrix facies and debris-avalanche blocks $<20$ meters wide. Scoured material, which consists primarily of wood, rock debris, and soil from adjacent ridges, is present only on top of the margins of the debrisavalanche deposit. The distal material at the west end of the avalanche deposit consists of jumbled piles of soil and splintered trees felled by the blast and shoved in front of the avalanche.

It is clear that the larger debris-avalanche blocks are surrounded by the mixed block and matrix facies map unit (pl. 4). Probably, the larger debris-avalanche blocks were carried by the mixed unit, but the relations are less clear for the smaller debris-avalanche blocks. This is discussed further in the next part of this section.

In the region $<2 \mathrm{~km}$ west of the break-in-slope, the larger debris-avalanche blocks are not surrounded by the mixed unit. Rather, debris-avalanche blocks of older dacite make up the entirety of the exposed area of the debrisavalanche deposit. These debris-avalanche blocks were probably carried from an upslope part of the avalanche by the mixed material and dropped just after traveling down the break-in-slope.

Aerial photographs of the distal $4 \mathrm{~km}$ of the deposit taken on May 19, 1980, by the Washington State Department of Transportation (fig. 47) reveal unexplained textural patterns on the south half of the deposit. These patterns are roughly perpendicular to the direction of flow, which is consistent with the interpretation that they could represent imbricated debris-avalanche blocks of the old mountain, with each block a different lithology. However, these patterns could not be recognized in the field, so they do not seem to reflect such a pattern of debris-avalanche blocks.

Soon after it came to rest, the entirety of the debris avalanche was covered with a thin coating $(<1 \mathrm{~cm})$ of the A3 airfall layer of the blast deposit (Waitt, 1981; Sisson, 1995). My photographs (fig. 44) of the debris-avalanche deposit on the afternoon of May 18 and the photographs of the deposit taken by Austin Post on May 18 and 19, 1980 (fig. 36), show that the dark areas on the deposit are lahars or are areas of wet A3. The unexplained patterns of figure 47 perhaps represent imbricate slices (but not debris-avalanche blocks) of the mixed block and matrix facies unit of the debris avalanche; the contrasting darkness of the stripes may represent contrasting moisture content in the slices resulting from varying degrees of saturation of the material. When a pair of the photographs is viewed with a stereoscope, some of the darkest (wettest?) stripes are observed to vaguely follow topography, and this is consistent with the above interpretation.

\section{LATERAL VARIATION IN DEBRIS-AVALANCHE BLOCK SIZE}

Because each map area does not necessarily represent only one block, the true size of debris-avalanche blocks is uncertain except where original volcanic structures define the blocks. The measurements of Ui (1985), Ui and Glicken (1986), and Siebert (1984) for volcanoes in Japan and the Cascade Range are very dependent on the size of exposures and generally reflect minimum block size. For this study, where debris-avalanche block boundaries can be identified, volumes were estimated from the topo- 


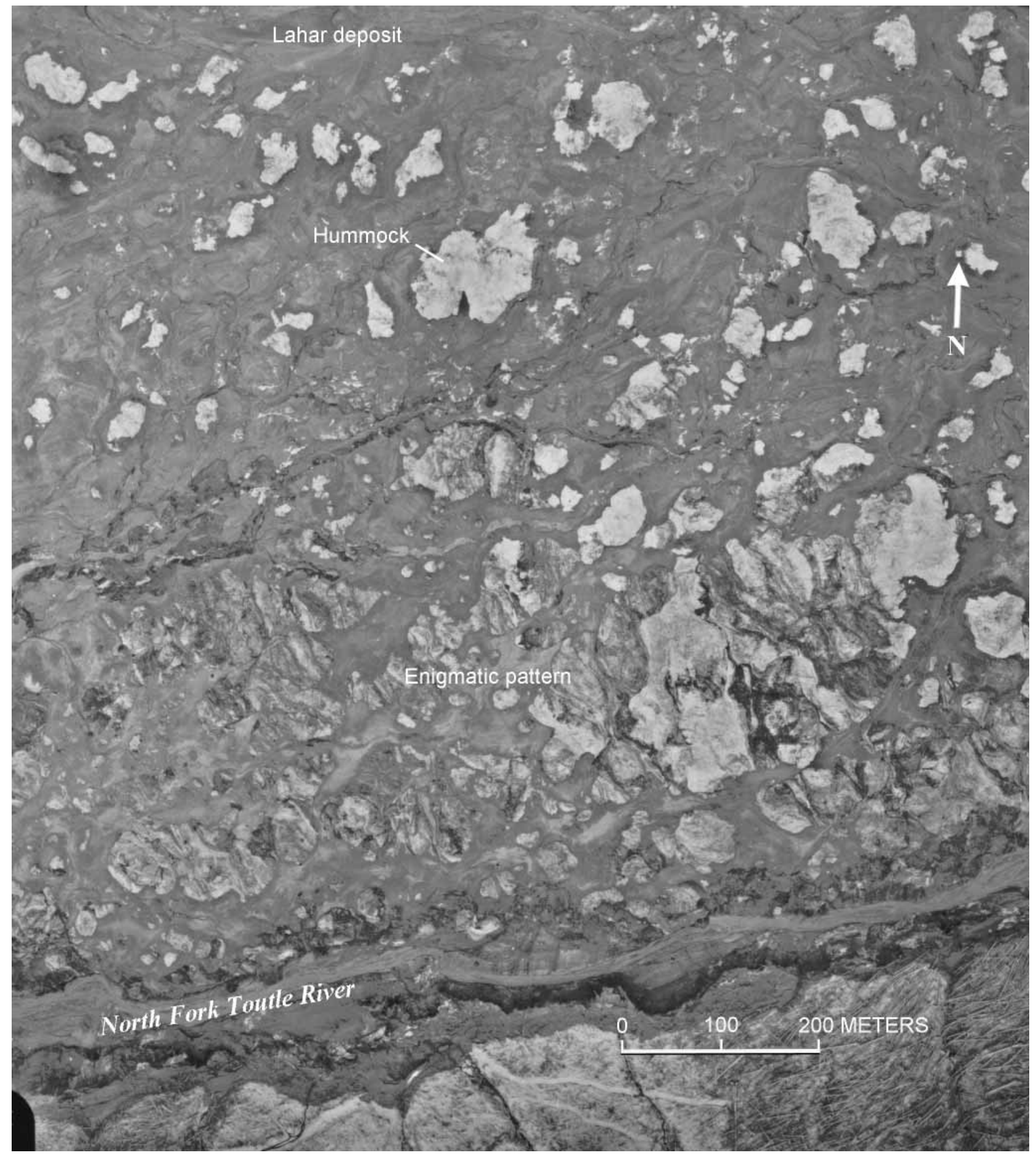

Figure 47. Aerial photograph taken May 19, 1980, showing enigmatic textural pattern on southern half of deposit. Photograph from Washington State Department of Transportation. 


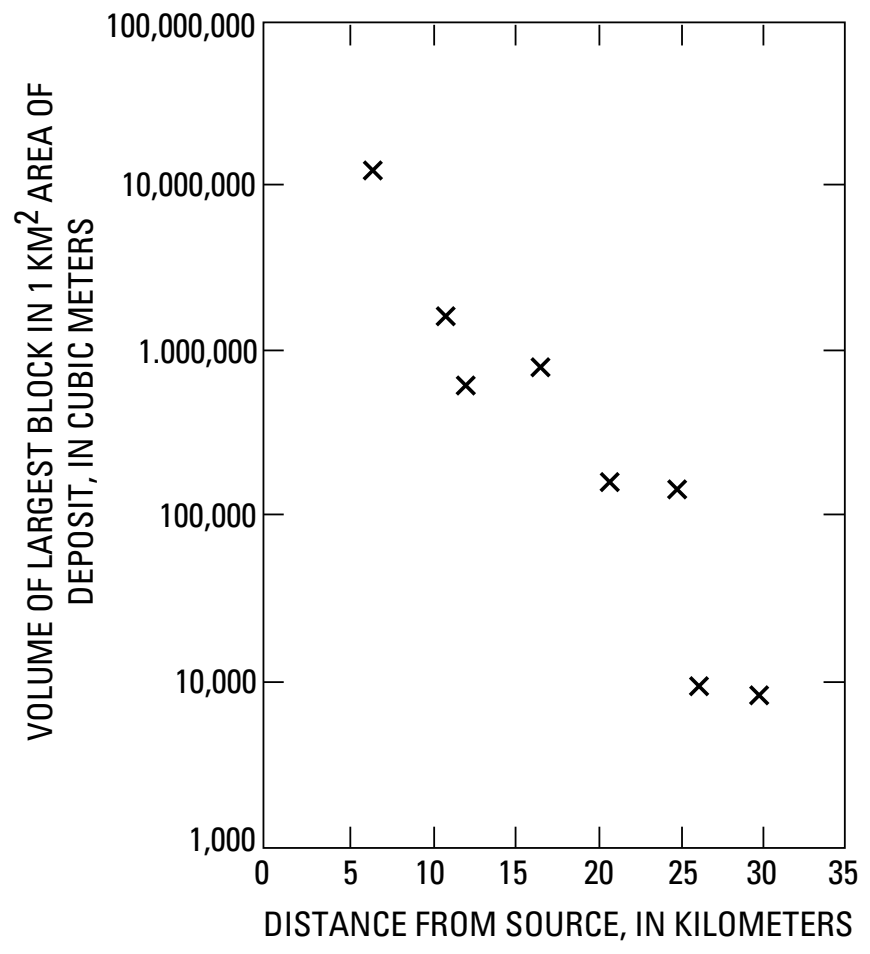

Figure 48. Volume of identified largest debris-avalanche blocks $(\log )$ in $1-\mathrm{km}^{2}$ areas versus distance from source (crater). Note general trend of decreasing debris-avalanche block size with distance.

graphic map and were plotted on a semi-log scale in figure 48. The definite trend of decreasing block size with distance from source indicates disaggregation of blocks during transport.

\section{TEXTURAL INTERPRETATION OF EXPOSURES}

\section{GENERAL STATEMENT}

The texture of the avalanche deposit on a scale smaller than the geologic maps was investigated in detail. Flat or inclined surfaces are covered with slope wash and other deposits of May 18, so avalanche textures are rarely visible in natural exposures. Because of the poor natural exposures, $1-\mathrm{m}^{2}$ vertical exposures were cleared with hand tools at 52 locations throughout the avalanche deposit (pl. 4) in order to study textures. The vertical exposures, here called "windows," were made as flat as possible, sprayed with water to enhance the contrast of colors, and then photographed (fig. 49).

Numerous data were gathered from each window. Maps of the distribution of different rock types in the rubble were made by overlaying drafting film on color photographic prints of the windows. The size distribution of clasts coarser than $-5 \phi(32 \mathrm{~mm})$ was measured by outlin-
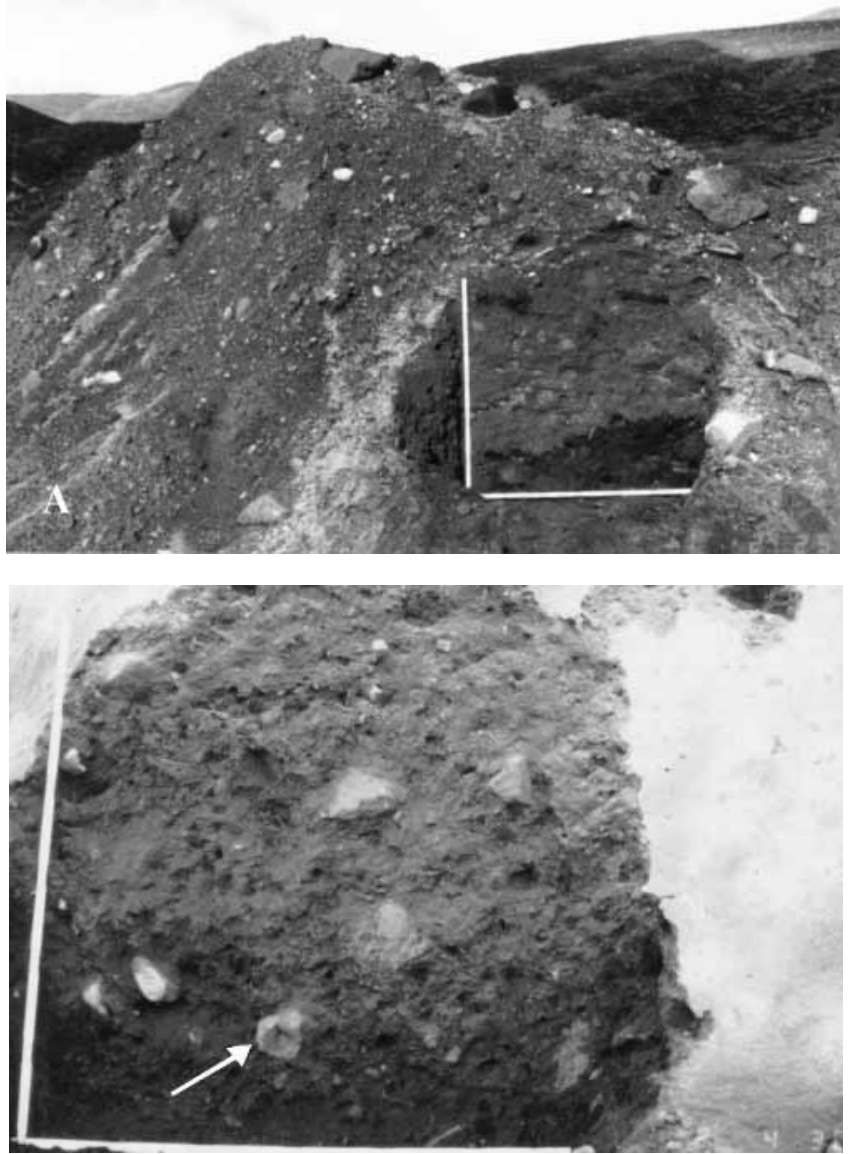

Figure 49. Photographs of typical $1-\mathrm{m}^{2}$ windows. A, DXS-26, showing both block facies and matrix facies (see line drawing type $6 \mathrm{dmx}$ in fig. 50). B, DXS-30, showing only matrix facies. Prismatically jointed clast (arrow) is juvenile blast dacite.

ing the areas of the clasts on the prints. A 2- to 3-kg sample was taken and standard sieve and pipette analyses were performed in order to determine the size distribution of clasts finer than $-5 \phi$. The three dimensions of the 10 largest clasts in each window were measured in order to compare similar measurements from other volcaniclastic deposits. The standard sand-cone test (American Society for Testing of Materials, 1977) was conducted to determine the in-place dry field density of the deposit. If matrix facies material was present in the window, or if block-facies windows were made of more than one rock type, approximately 100 clasts $>2 \mathrm{~cm}$ wide were classified by rock type (table 3 ).

\section{DESCRIPTION OF WINDOWS}

In order to provide a catalog of the different types of exposures in the debris-avalanche deposit, to study the texture of the deposit in a way directly comparable to methods possible in most prehistoric deposits (for example, Shasta Valley debris avalanche; Bandai-san debris 
avalanche), and to provide data to interpret the processes involved in the transport of the material, line drawings (maps) of the windows (fig. 50) were constructed. The outlined areas on the windows represent different rock types and/or colors as measured in the field on a Munsell rock-color chart. Each color represents a different rock type or varying degrees of alteration within the old mountain.

The textures are classified into seven general types based on examination of the maps in figure 50. Four types contain only block facies, two contain both matrix and block facies, and one contains only matrix facies.

\section{BLOCK-FACIES WINDOWS}

Type 1 exposures contain structures that closely resemble original volcanic structures observed in the crater. The structures are lava flows, platy jointing of domes, dikes, and layered sequences of tephra. Locality DXS-12 is composed entirely of modern dacite rock exhibiting platy dome jointing. The other types of struc-

\section{Type 1-Modern dacite unit}

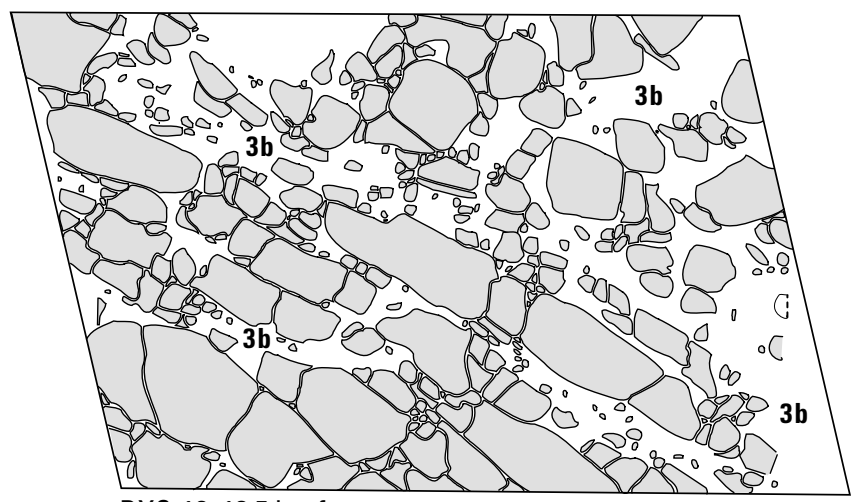

DXS-12; $13.5 \mathrm{~km}$ from source
Type 2-Older dacite unit

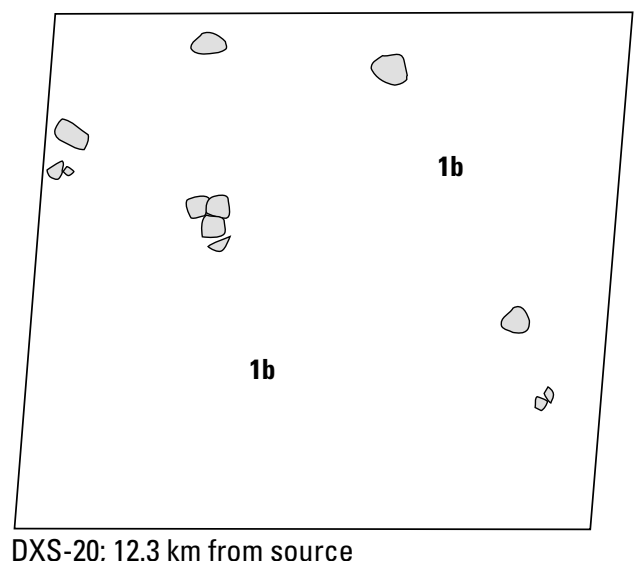

\begin{tabular}{|lll|}
\hline & \multicolumn{1}{c|}{ EXPLANATION } & \\
a Olive gray & h Olive brown & o Brown red \\
b Gray & i Yellow brown & p Dusky red \\
c Reddish Brown & j Greenish gray & q Dusky red brown \\
d Grayish black & k Black & r Grayish orange pink \\
e Grayish red & I Brown & s Yellowish gray \\
f Olive black & m Yellow orange & t Brownish black \\
g Red & n Blackish red & u Brownish gray \\
& & v Dusky brown \\
& & \\
$\mathbf{1}$ Older dacite & Lum Pre-1980 pumice & org Organic-rich material, \\
$\mathbf{2}$ Andesite and basalt & mtx Matrix facies & generally soil or wood \\
$\mathbf{3}$ Modern dacite & bl Blast deposit & \\
\hline
\end{tabular}

Figure 50. Line drawings of windows (1- $\mathrm{m}^{2}$ exposures cleared of colluvium and slope wash) at various localities throughout avalanche. See plate 4 for localities. Of the seven types of texture, four contain only block facies, two both block and matrix facies, and one only matrix facies. Solid lines bound clasts visible on scale of windows (larger than $1 \mathrm{~cm}$ ). Long dashes define contacts between colors where sharp to within $2 \mathrm{~cm}$ on window. Short dashes indicate diffuse contacts. Color designations from field measurements using Munsell Rock Color Chart. Intensity modifiers (light, dark, etc.) not used. 
Type 2-Older dacite unit

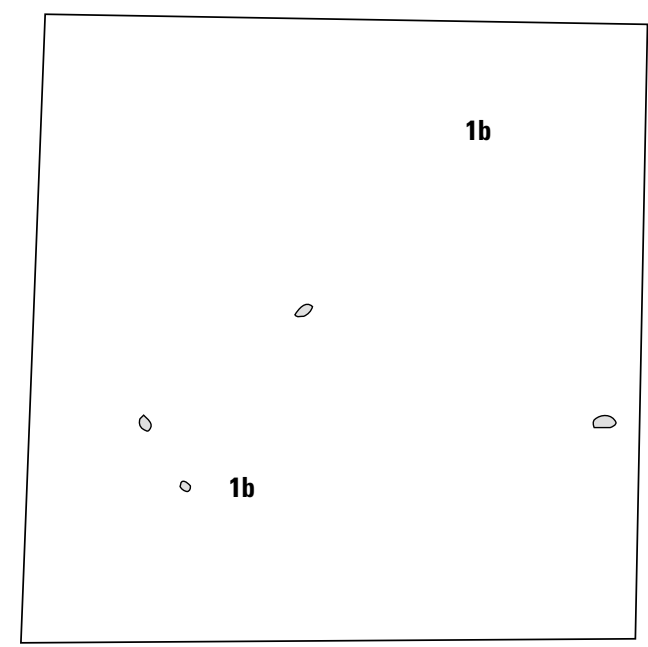

826-3; $16.4 \mathrm{~km}$ from source

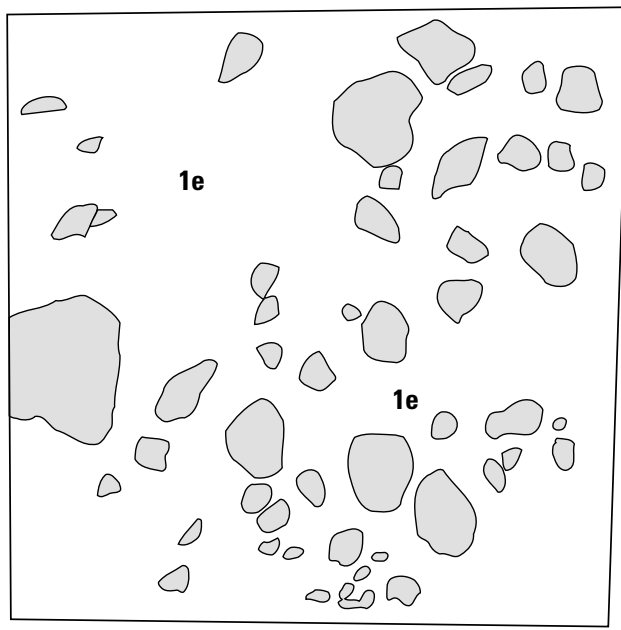

DXS-2; $25.3 \mathrm{~km}$ from source

Type 2-Andesite and basalt unit

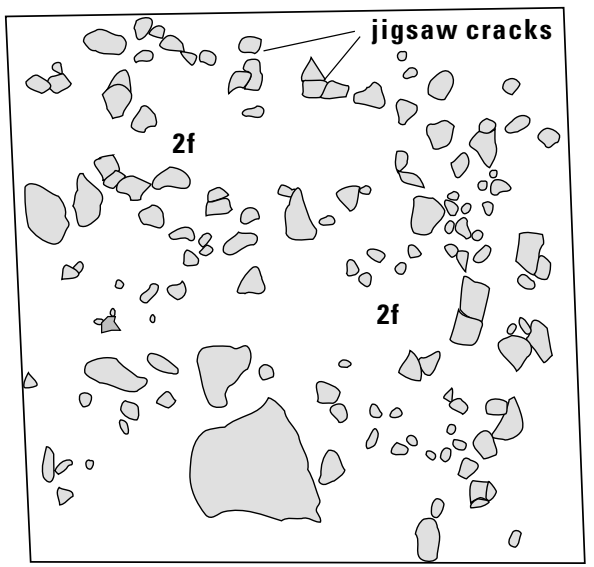

$825-5 ; 9.4 \mathrm{~km}$ from source
Type 2-Andesite and basalt unit

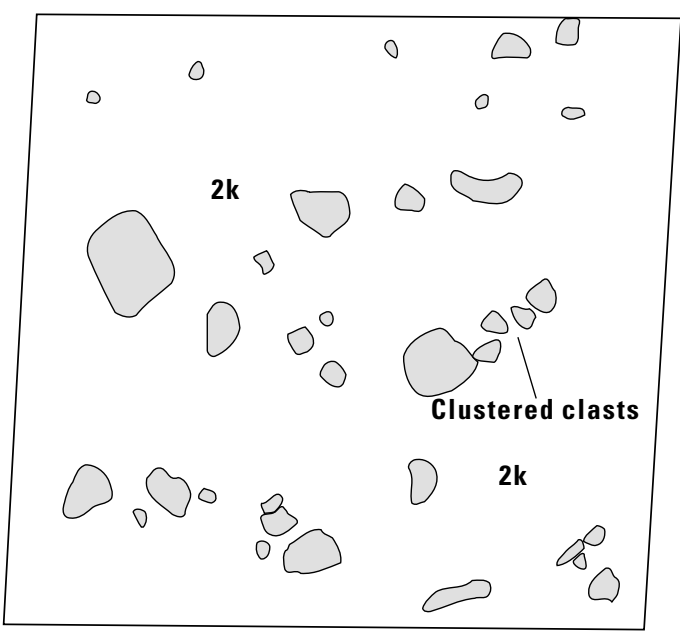

DXS-16; $11.3 \mathrm{~km}$ from source

Type 3-Older dacite unit

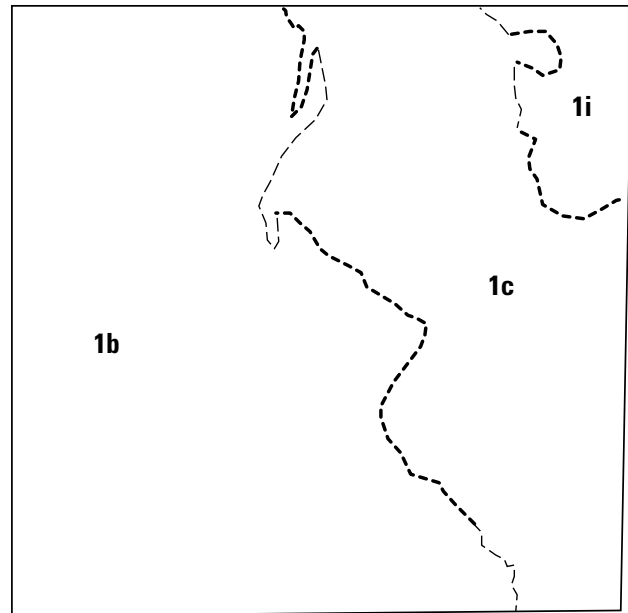

$827-3 ; 9.7 \mathrm{~km}$ from source

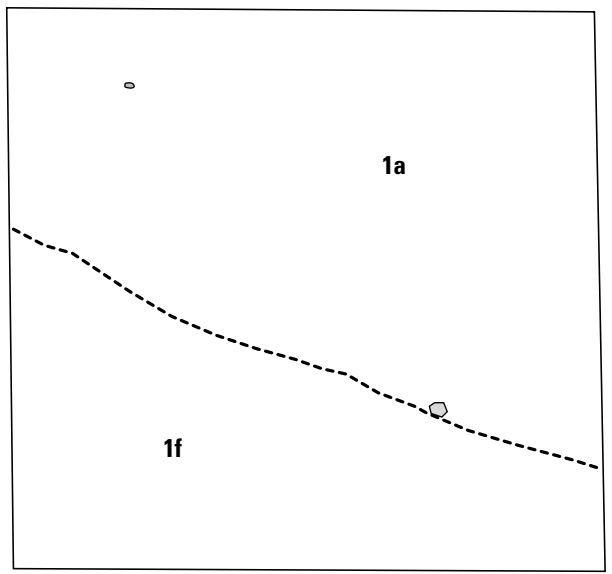

DXS-24; $13.3 \mathrm{~km}$ from source

Figure 50. Line drawings of windows (1- $\mathrm{m}^{2}$ exposures cleared of colluvium and slope wash) at various localities throughout avalanche-Continued. 
Type 3-Older dacite unit

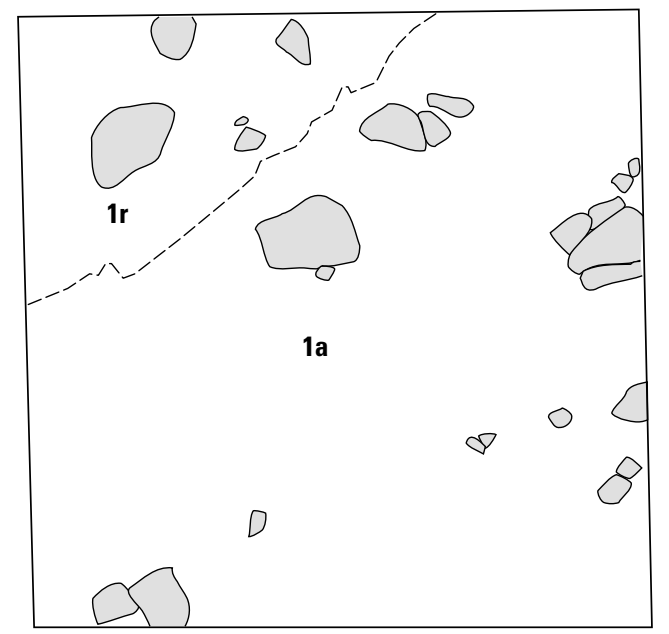

DXS-6; $15.6 \mathrm{~km}$ from source

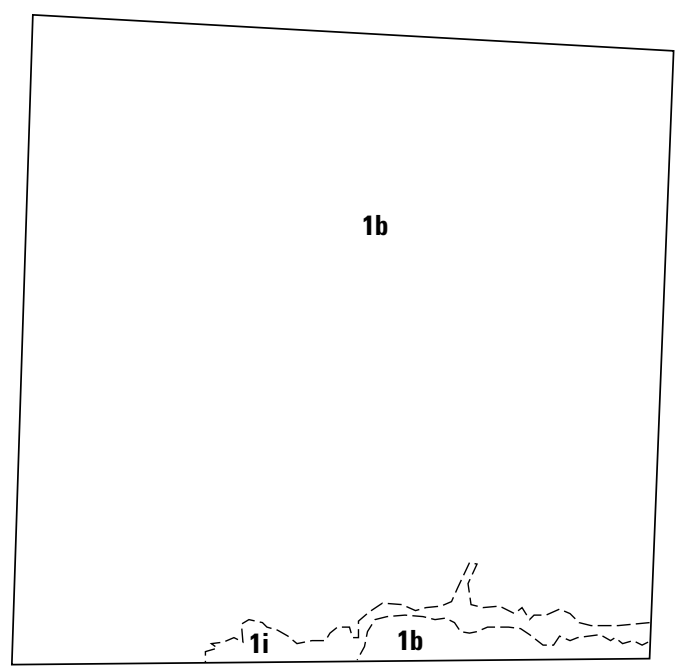

MS-10; $16.9 \mathrm{~km}$ from source

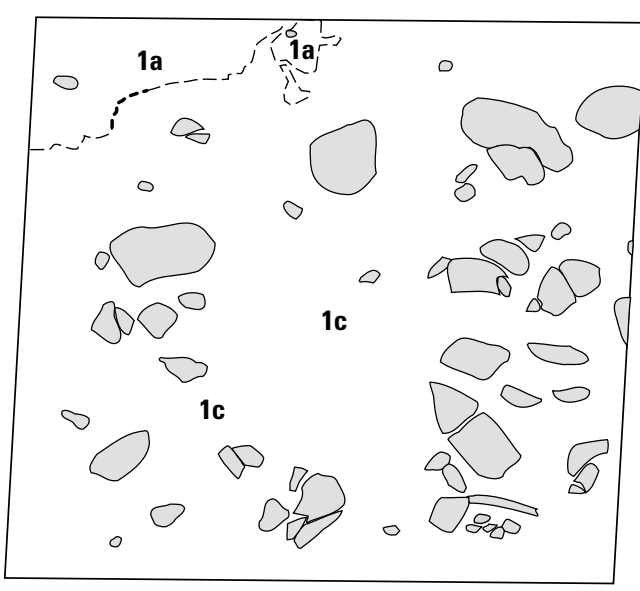

DXS-22; $17.6 \mathrm{~km}$ from source
Type 3-Older dacite unit

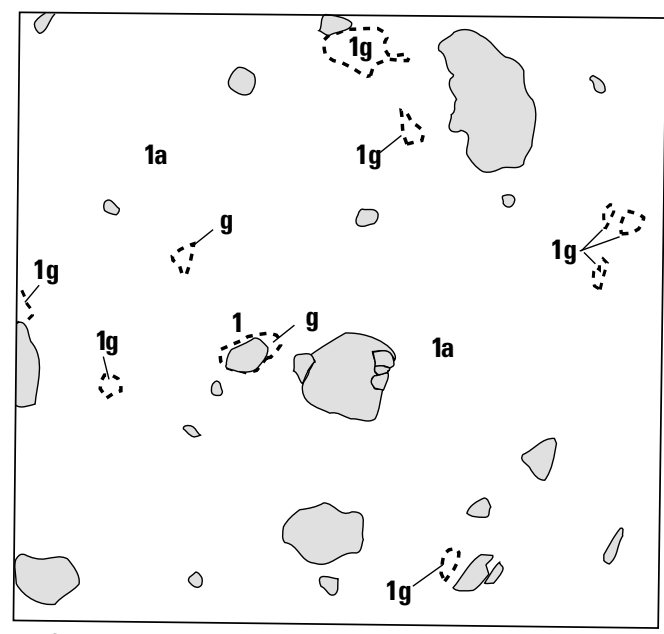

DXS-21; $18.4 \mathrm{~km}$ from source

Type 3-Andesite and basalt unit
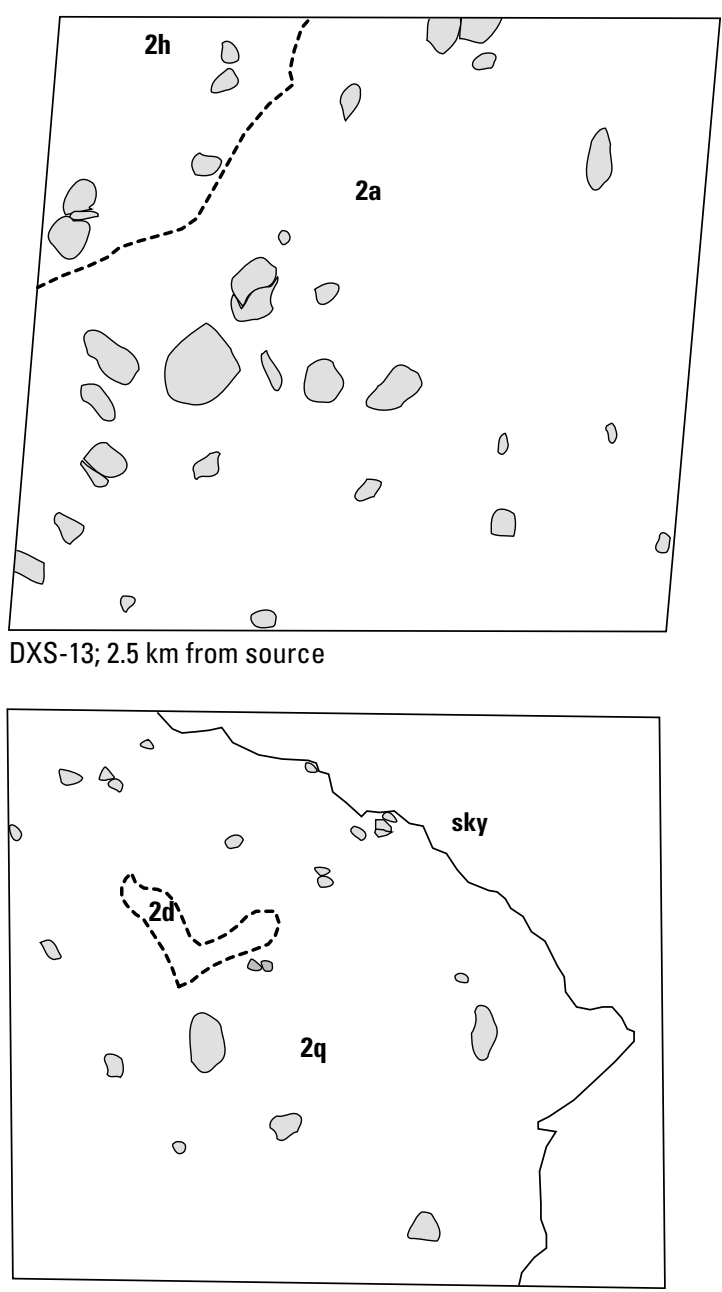

DXS-14; $2.7 \mathrm{~km}$ from source

Figure 50. Line drawings of windows (1- $\mathrm{m}^{2}$ exposures cleared of colluvium and slope wash) at various localities throughout avalancheContinued. 
Type 3-Andesite and basalt unit

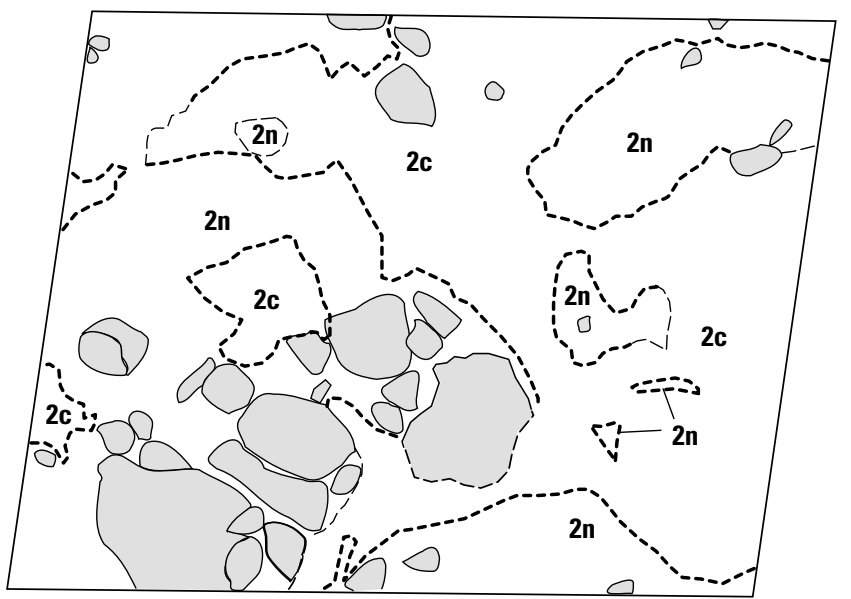

DXS-23; $13 \mathrm{~km}$ from source

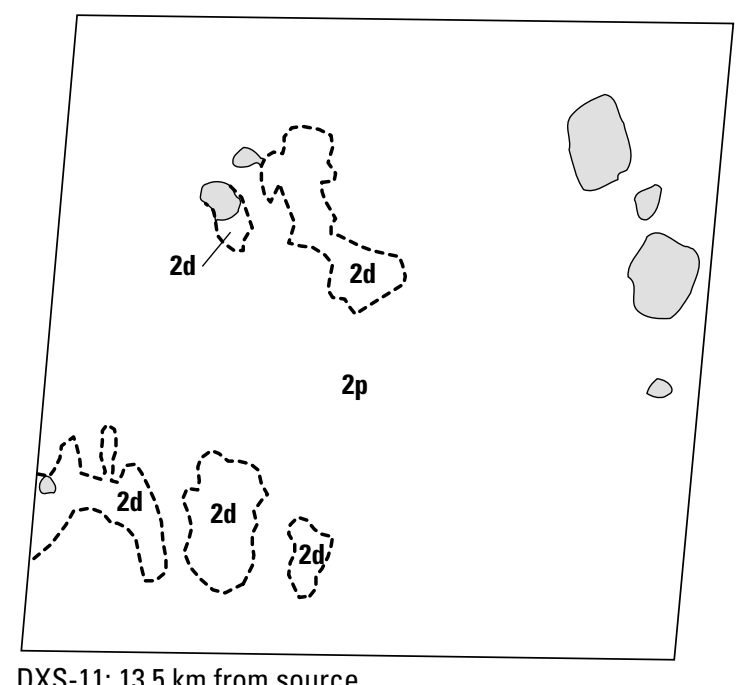

DXS-11; $13.5 \mathrm{~km}$ from source

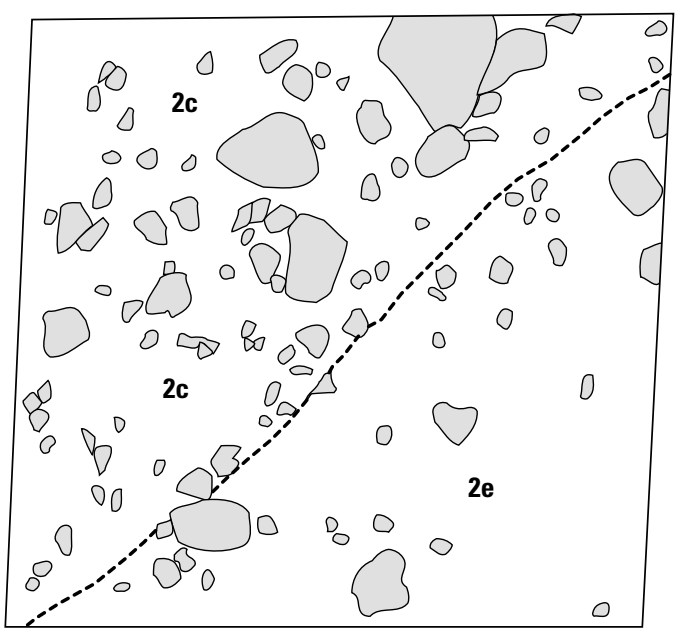

DXS-25; $14.6 \mathrm{~km}$ from source
Type 3-Andesite and basalt unit

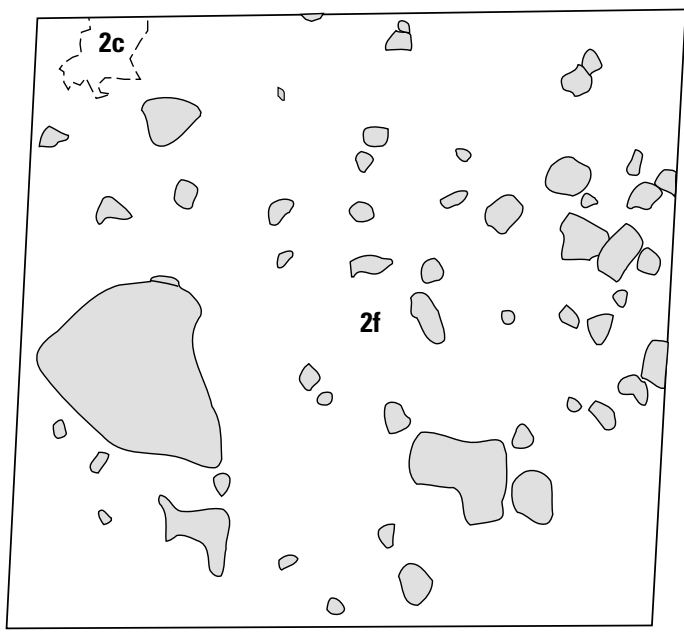

DXS-27; $17.7 \mathrm{~km}$ from source

Type 3-Modern dacite unit

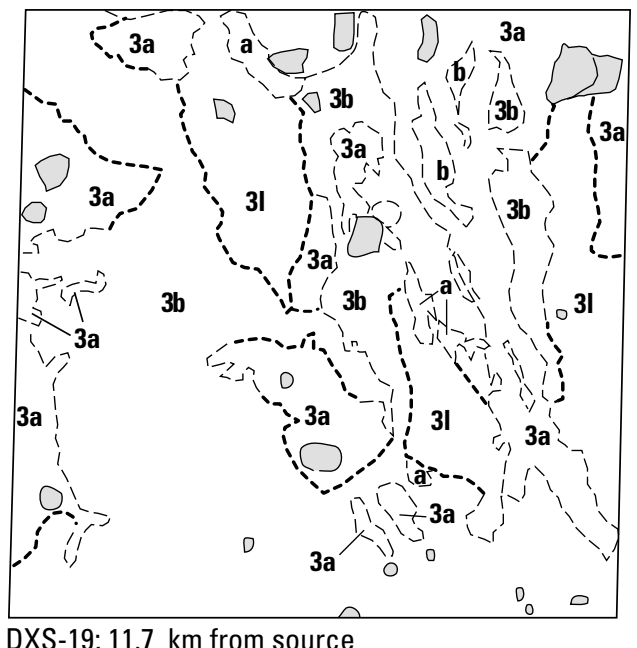

DXS-19; $11.7 \mathrm{~km}$ from source

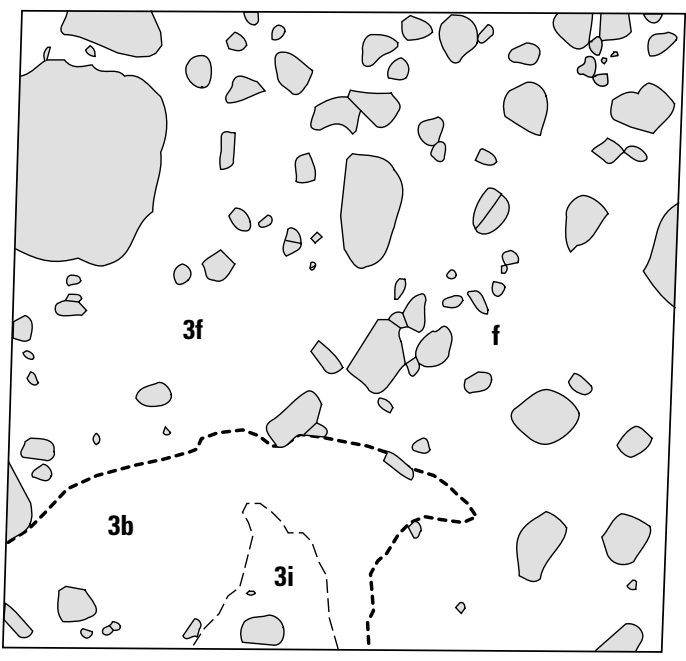

DXS-3; 15.7 km from source

Figure 50. Line drawings of windows (1- $\mathrm{m}^{2}$ exposures cleared of colluvium and slope wash) at various localities throughout avalancheContinued. 
Type 3-Modern undifferentiated unit

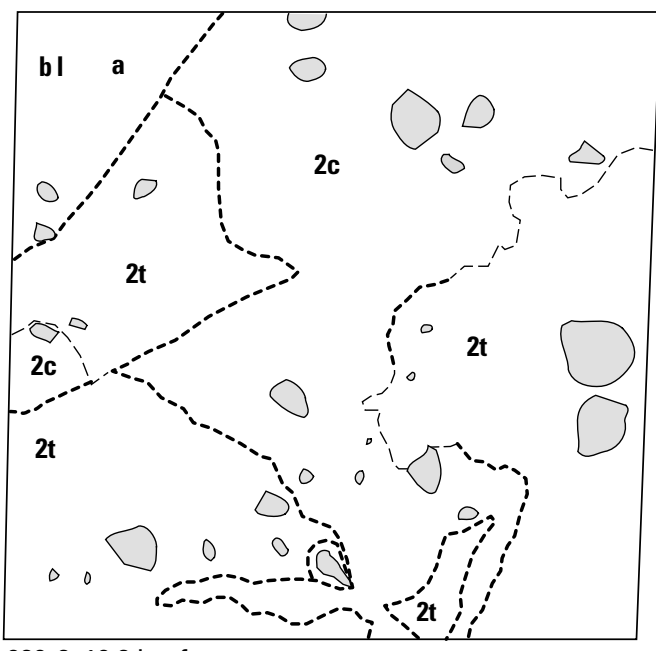

$826-2 ; 16.2 \mathrm{~km}$ from source

Type 4-Older dacite unit

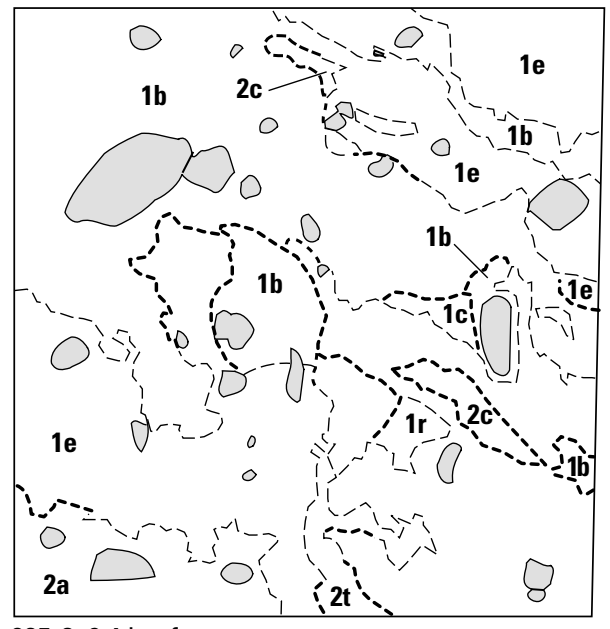

825-3; $9.4 \mathrm{~km}$ from source

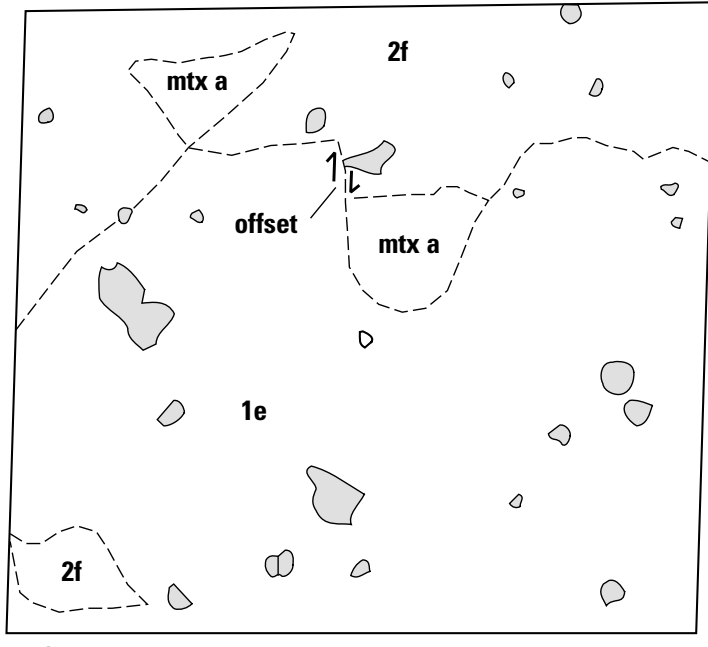

DXS-4; $15.1 \mathrm{~km}$ from source
Type 4-Andesite and basalt unit

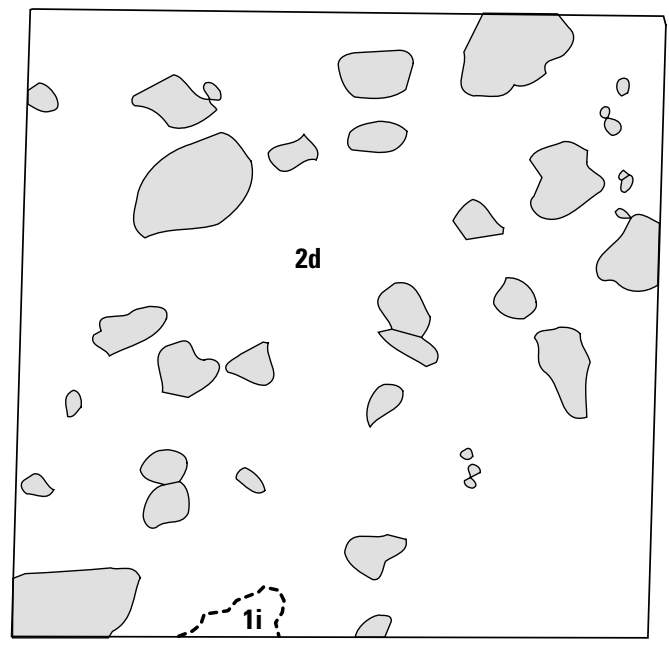

827-2; $10.6 \mathrm{~km}$ from source

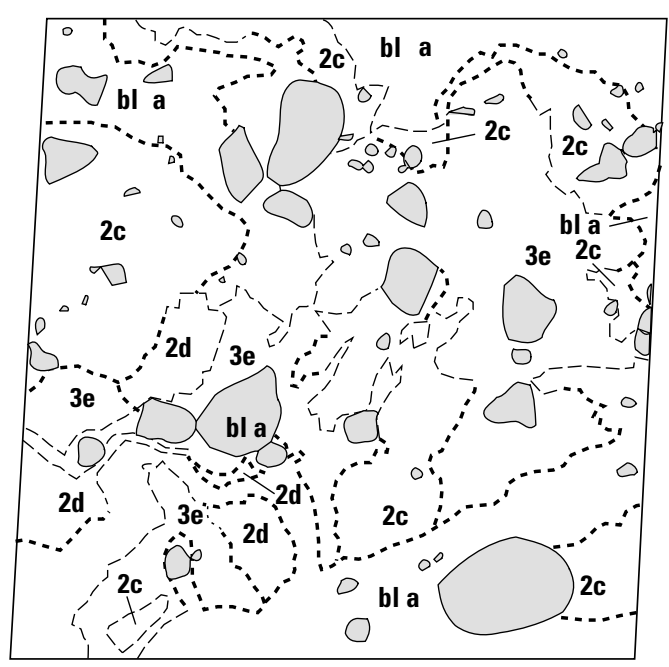

MS-9; $16.9 \mathrm{~km}$ from source

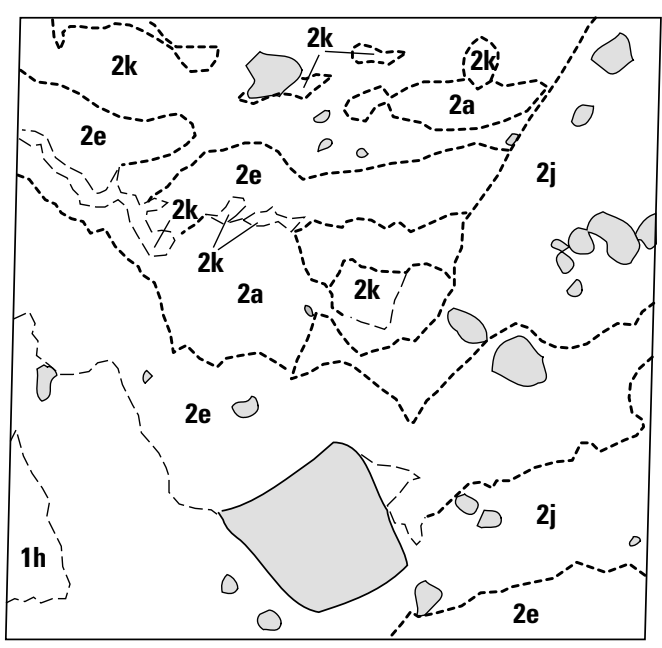

DXS-38; $29.7 \mathrm{~km}$ from source

Figure 50. Line drawings of windows (1- $\mathrm{m}^{2}$ exposures cleared of colluvium and slope wash) at various localities throughout avalancheContinued. 
Type 4-Modern undifferentiated unit

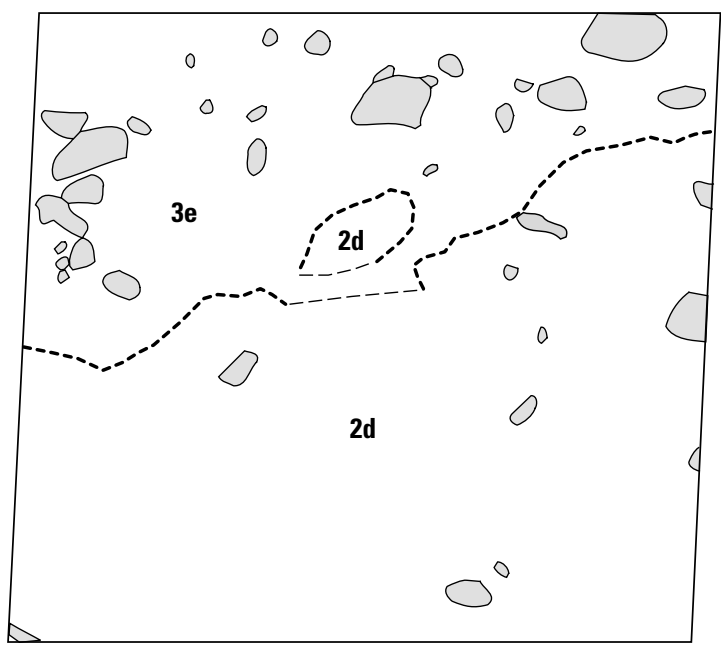

DXS-17; $12.4 \mathrm{~km}$ from source

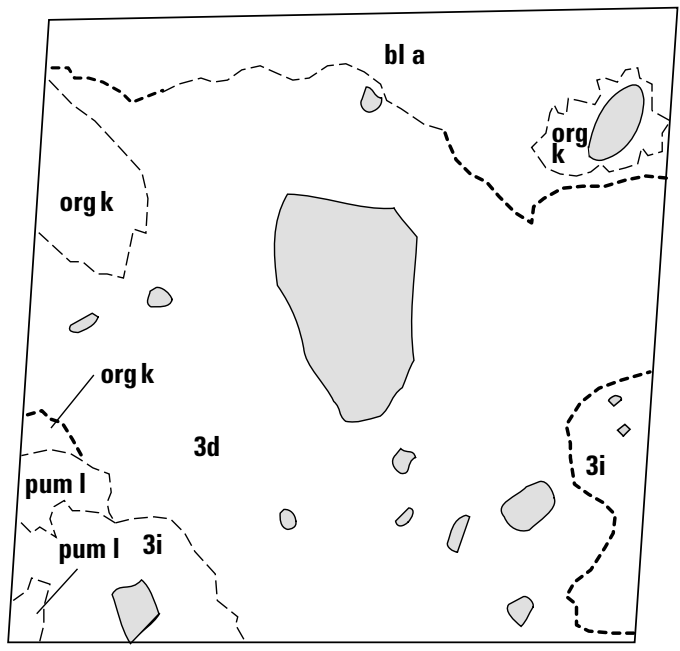

827-6; $15.9 \mathrm{~km}$ from source

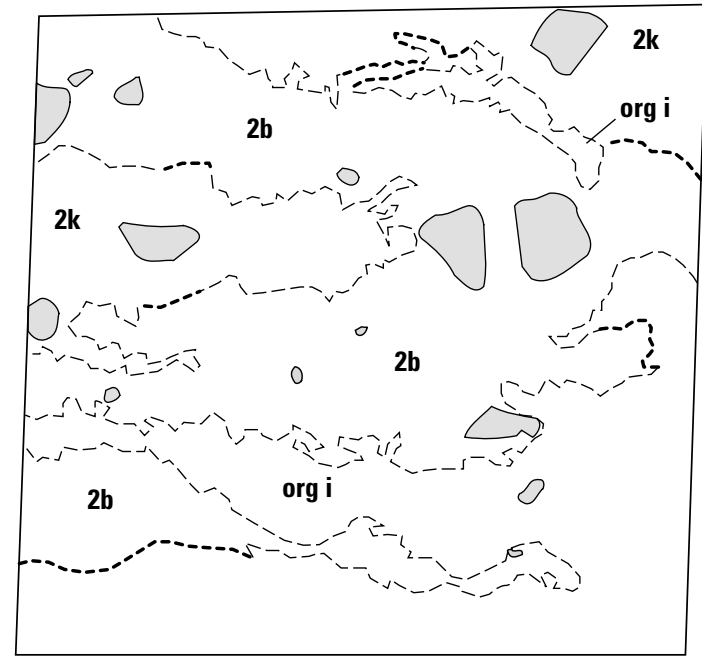

827-7; $15.9 \mathrm{~km}$ from source
Type 4-Mixed block and matrix facies unit

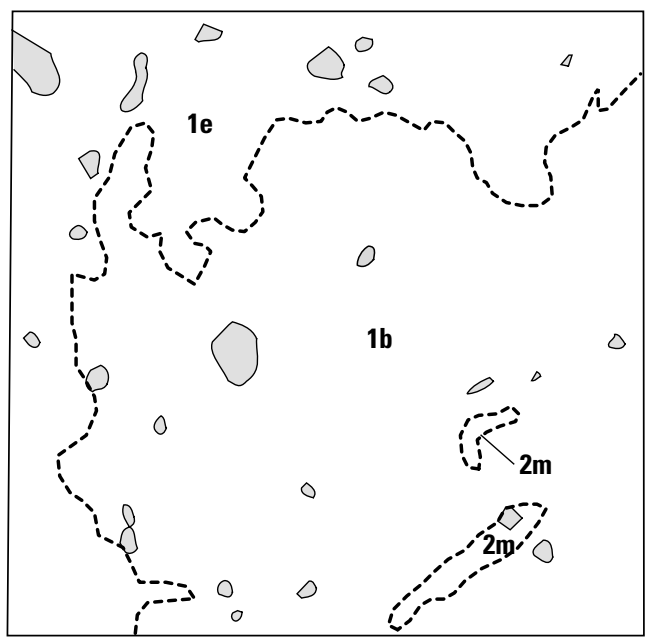

DXS-8; $25.8 \mathrm{~km}$ from source

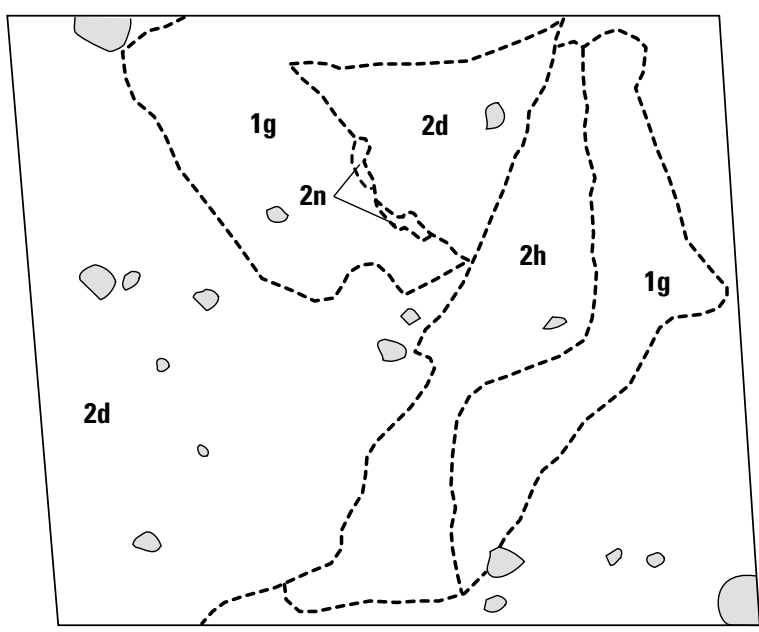

DXS-34; $26.8 \mathrm{~km}$ from source

Type 5-Mixed block and matrix facies unit

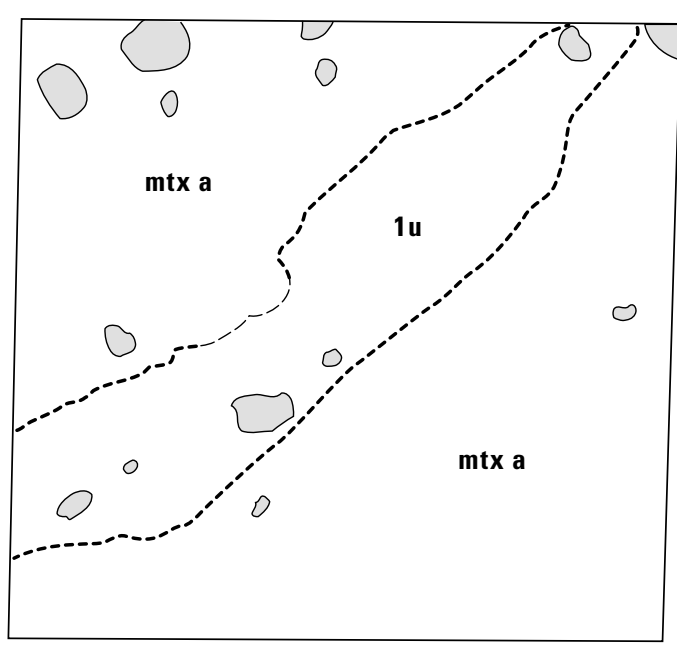

DXS-29; $21.4 \mathrm{~km}$ from source

Figure 50. Line drawings of windows (1- $\mathrm{m}^{2}$ exposures cleared of colluvium and slope wash) at various localities throughout avalancheContinued. 
Type 5-Mixed block and matrix facies unit

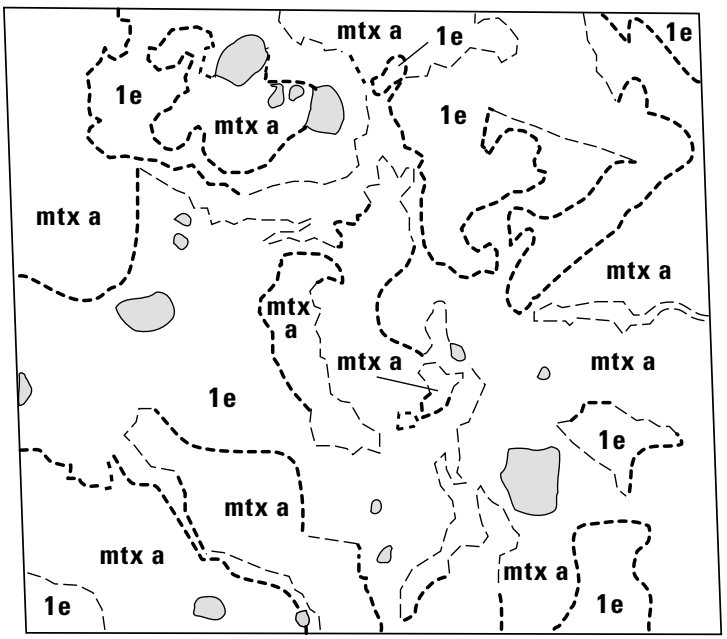

DXS-31; $23.1 \mathrm{~km}$ from source

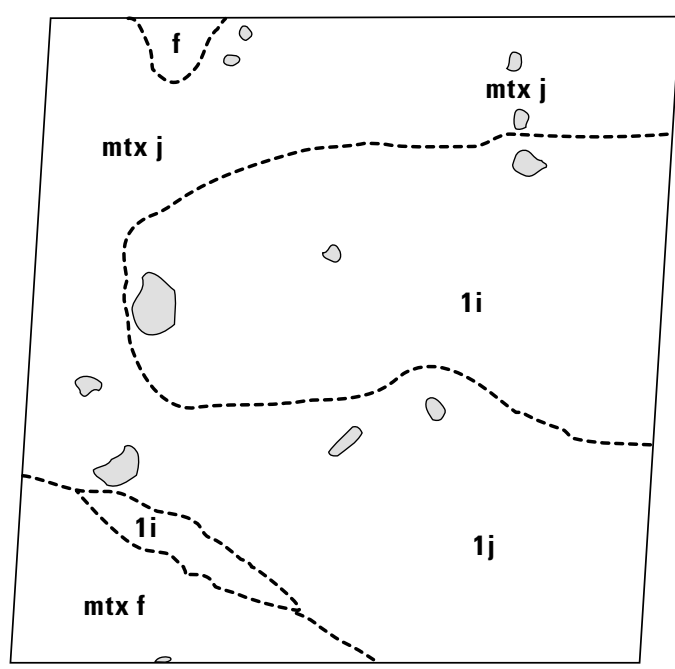

DXS-37; $30.7 \mathrm{~km}$ from source

Type 6-Modern dacite unit

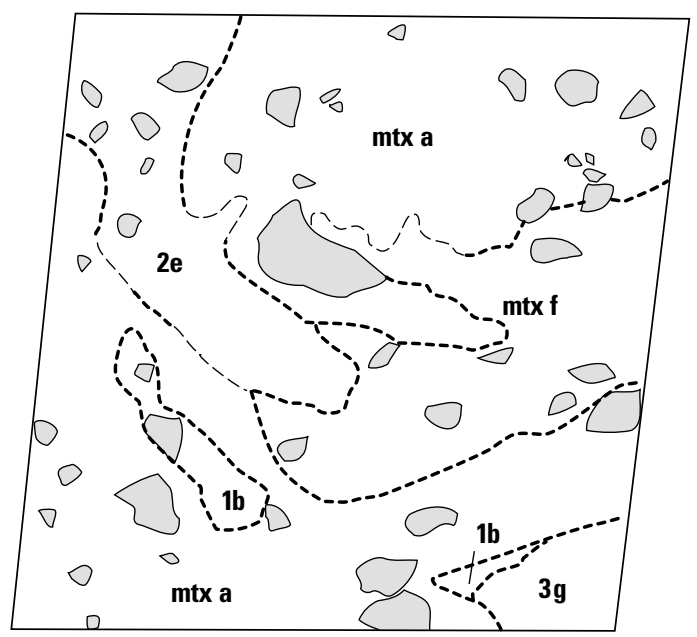

MS-1; $17.2 \mathrm{~km}$ from source
Type 6-Mixed block and matrix facies unit

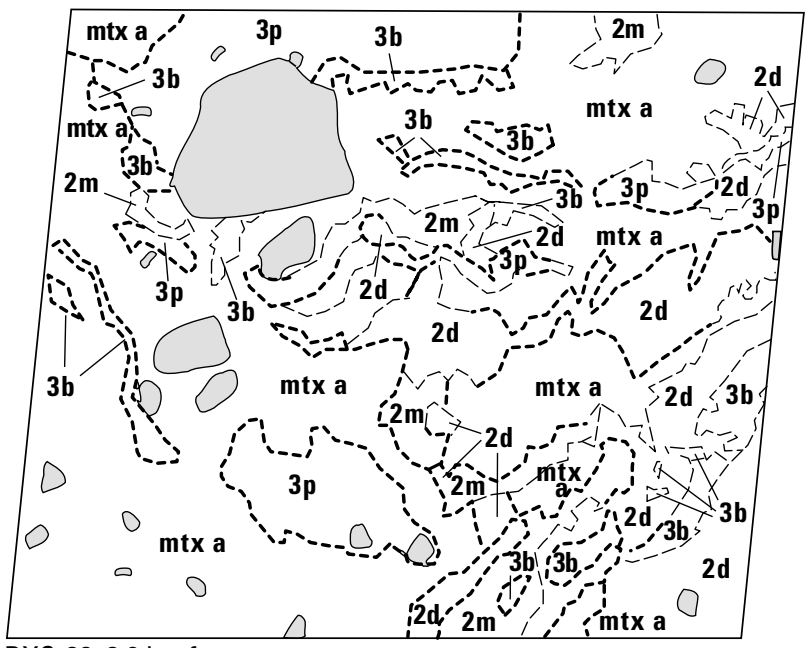

DXS-32; $3.6 \mathrm{~km}$ from source

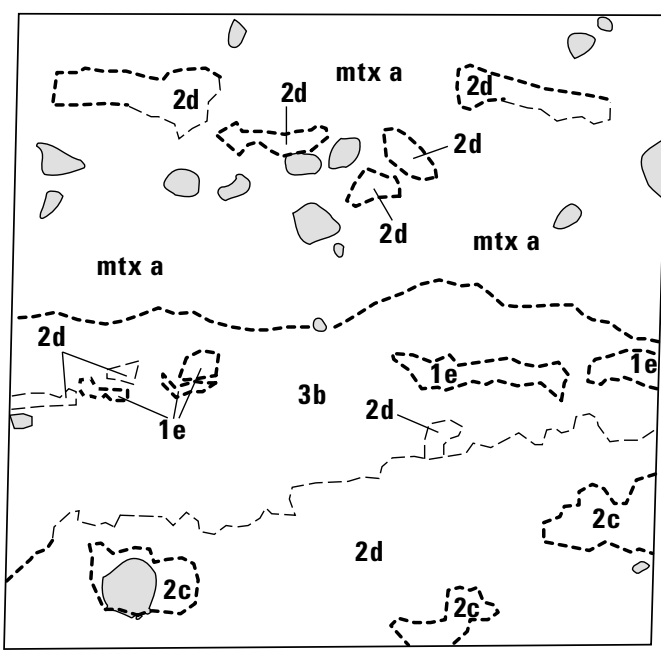

DXS-26; $17.7 \mathrm{~km}$ from source

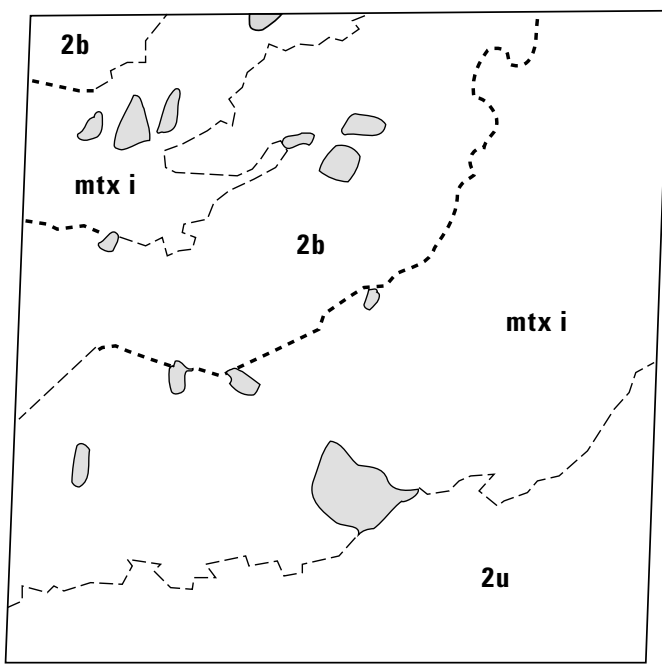

DXS-28; $21.0 \mathrm{~km}$ from source

Figure 50. Line drawings of windows (1- $\mathrm{m}^{2}$ exposures cleared of colluvium and slope wash) at various localities throughout avalancheContinued. 
Type 6-Mixed block and matrix facies unit

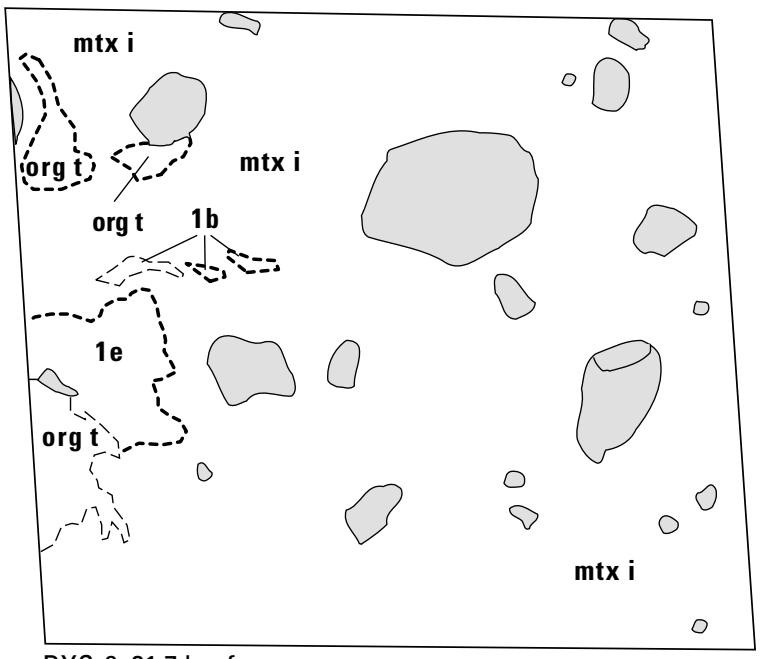

DXS-9; $21.7 \mathrm{~km}$ from source

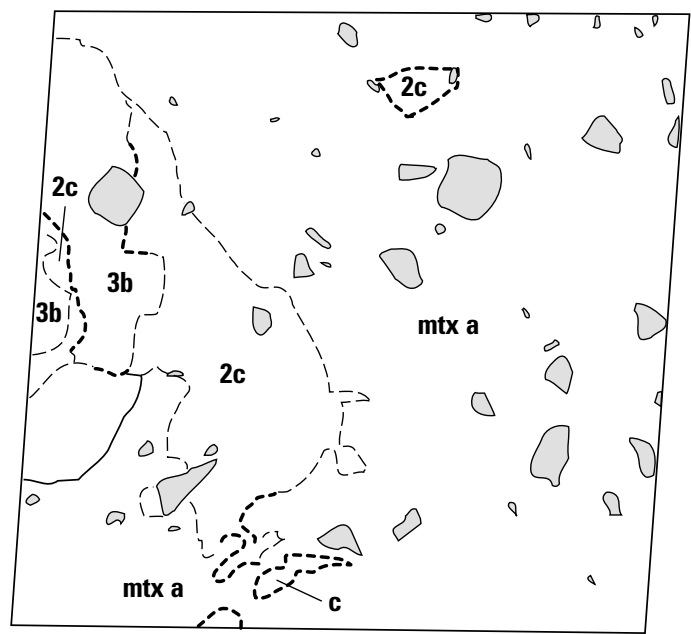

DXS-33; $24.5 \mathrm{~km}$ from source

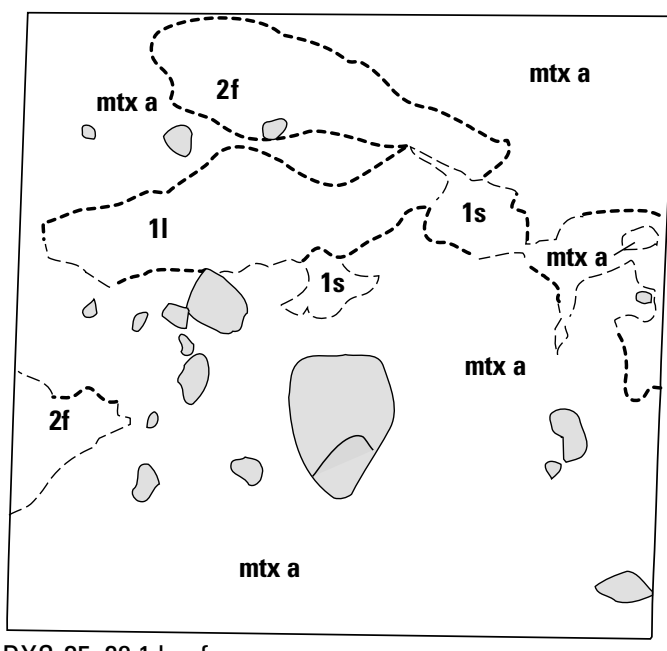

DXS-35; $28.1 \mathrm{~km}$ from source
Type 6-Mixed block and matrix facies unit
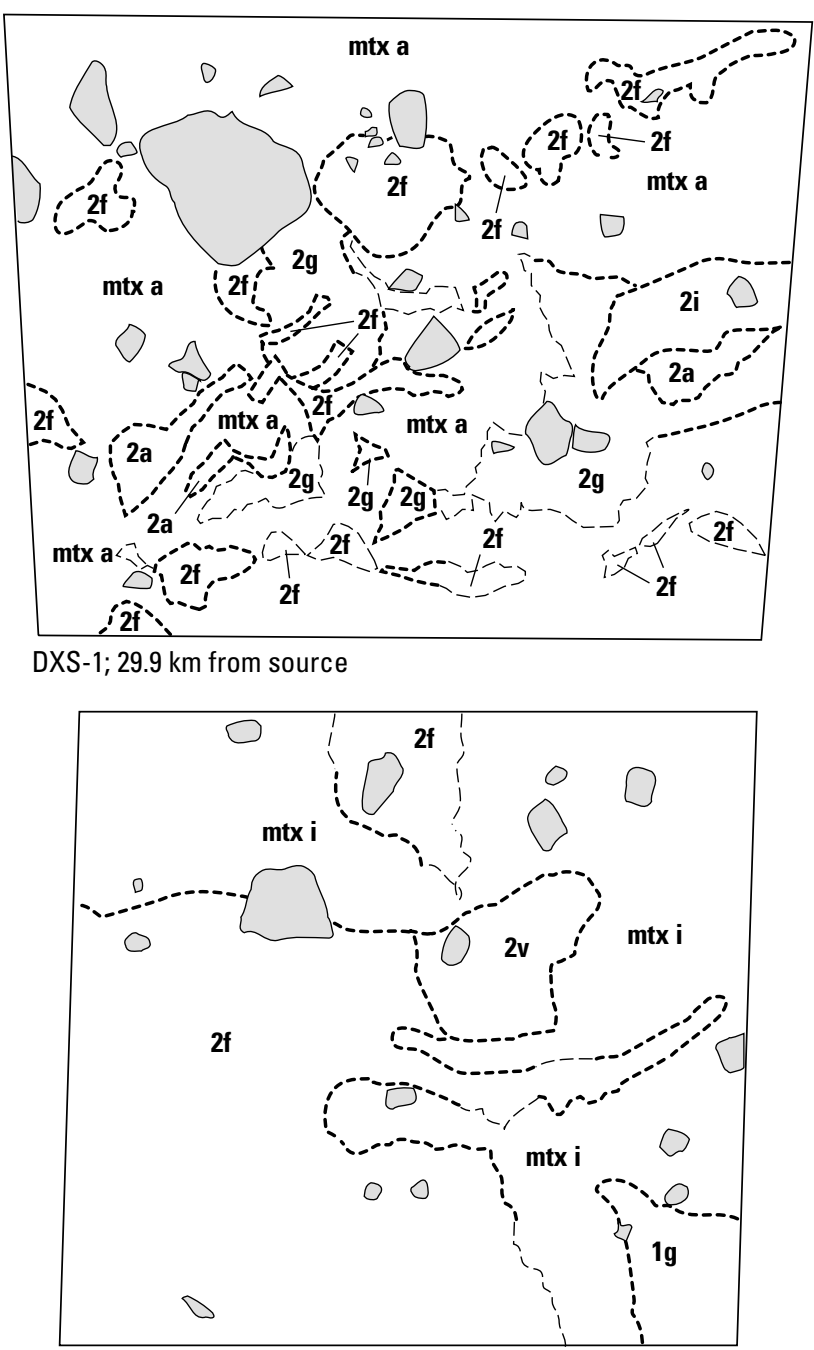

DXS-36; $31.2 \mathrm{~km}$ from source

Type 7-Mixed block and matrix facies unit

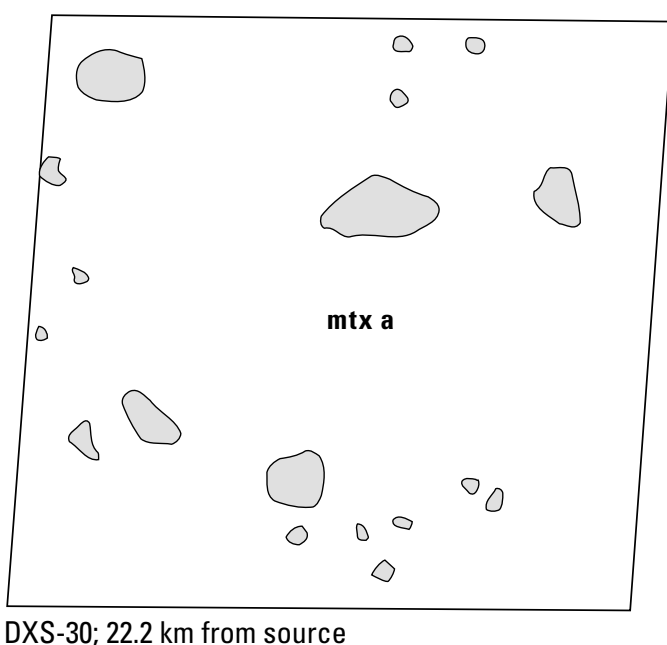

Figure 50. Line drawings of windows (1- $\mathrm{m}^{2}$ exposures cleared of colluvium and slope wash) at various localities throughout avalancheContinued. 
Type 7-Blast Deposit

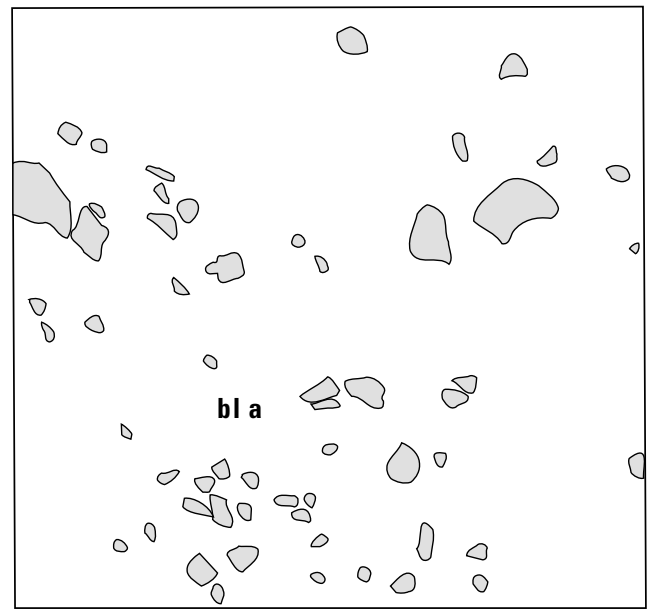

DXS-18; $11.5 \mathrm{~km}$ from source

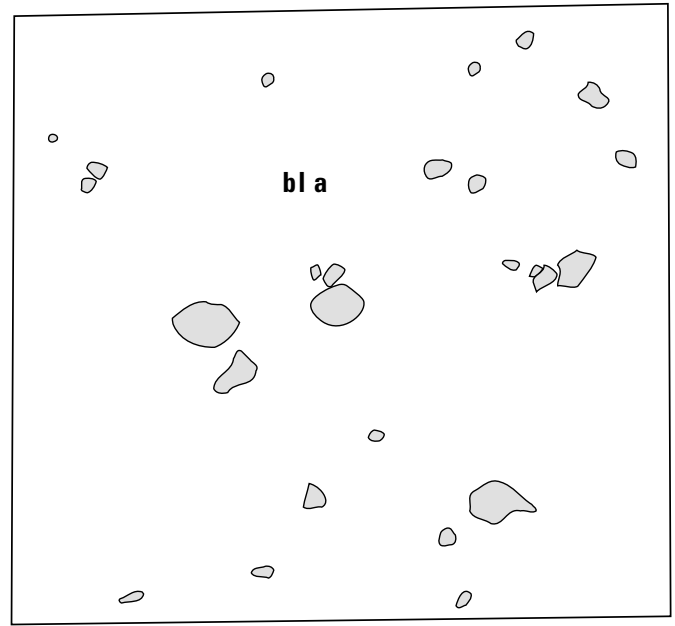

DXS-5; $13.4 \mathrm{~km}$ from source

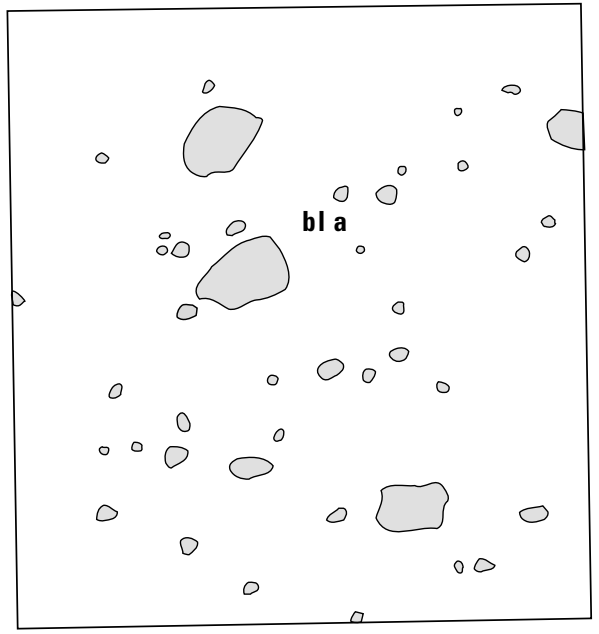

$826-4 ; 16.6 \mathrm{~km}$ from source

Figure 50. Line drawings of windows $\left(1-\mathrm{m}^{2}\right.$ exposures cleared of colluvium and slope wash) at various localities throughout avalanche--Continued. tures were not seen in the windows, but were observed in various localities in the deposit (figs. 13A, 14, 31-34, and 46).

Type 2 exposures are composed entirely of one rock type and one color. The homogeneity of the material makes it difficult to determine the amount of deformation and mixing within the material. Locally, the presence of clasts that are fractured but not disaggregated (e.g., 825-5; "jigsaw cracks" of Ui, 1985) and clasts clustered together rather than dispersed throughout the material (probably disaggregated from jigsaw cracks; for example, DXS-16) indicate that parts of the material travelled together as a unit with little deformation.

Type 3 windows show more than one color, but only one rock type. The colors represent different degrees of alteration of the material (Pevear and others, 1982). The boundaries between the colors are either sharp or diffuse. Commonly, the material is deformed into numerous rubble schlieren (for example, DXS-19).

Type 4 windows show more than one rock type and generally more than one color. The boundaries between the rock types and between the colors are either sharp or diffuse and may be deformed into rubble schlieren but show no apparent stratification. The different rock types may represent different debris-avalanche blocks or may represent contacts between different rock types within a block. Commonly, these windows exhibit roughly horizontal stratification of rubble schlieren (for example, 825$3,827-7)$.

\section{BLOCK- AND MATRIX-FACIES WINDOWS}

Type 5 windows show only one rock type in the block facies and contain some of the blended matrix facies material. The boundaries between the rock types and colors are either sharp or diffuse. Locally, the windows exhibit roughly horizontal stratification of the rubble schlieren (for example, DXS-37).

Type 6 windows show more than one rock type in the block facies and contain some of the blended matrix facies material. The boundaries between the rock types and colors are either sharp or diffuse. Locally, the windows exhibit roughly horizontal stratification of the rubble schlieren (for example, DXS-35).

\section{MATRIX-FACIES WINDOWS}

Type 7 windows consist entirely of matrix facies material. All the rock types are blended together, so there are no rubble schlieren. These windows are identical in appearance to unsorted and unstratified exposures of the blast deposit (for example, DXS-18). 


\section{DISCUSSION OF WINDOWS}

The windows represent a sampling of the internal texture of the avalanche deposit. They provide evidence for varying degrees of fracturing of clasts and disaggregation and mixing of material during the formation and transport of the rockslide-debris avalanche. In addition, they are close analogs to road-cut or stream-cut exposures in an old deposit, and observations of similar features in an old deposit can help identify it as the deposit of a debris avalanche.

The walls of the 1980 crater reveal horizontally stratified lava flows and pyroclastic material, vertical dikes, and other structures characteristic of the inside of a volcano (see "Geology of the Source Area"). In the debrisavalanche deposit, similar exposures (type 1 windows, and $13 A, 14,31-34$, and 46) are striking but rare, and commonly the volcanic structure or stratigraphy is at least slightly deformed. Moreover, the fact that most of the type 1 exposures, which show fewer large clasts than similar exposures in the crater indicates that the material was shattered before deposition. This is in contrast with other debris-avalanche deposits (for example, at Mount Shasta; Crandell and others, 1984, Ui and Glicken, 1986) where well-preserved volcanic structures and stratigraphy are common.

Type 2 windows lack such well-preserved features, but because they are composed of only one rock type it is difficult to determine the amount of deformation of the material. Jigsaw cracks indicate that the clasts were fractured but not shattered, and that the fragments of the clasts were not dispersed; the paucity of jigsaw cracks at the Mount St. Helens deposit relative to other deposits (Ui and Glicken, 1986; Tadahide Ui, oral commun., 1984) suggests that the clasts in the Mount St. Helens deposit were much more thoroughly shattered than the clasts in most other deposits. However, clustered clasts are apparent in many exposures, which indicates that all clasts were not completely dispersed and at least parts of the material traveled as units from source to place of deposition.

Type 3 windows are composed of only one debrisavalanche block but show colors (representing different degrees of hydrothermal alteration) that enable insight on the amount of internal deformation. Generally, the material is deformed into numerous rubble schlieren. Because the exposures are monolithologic, each exposure probably is from just one debris-avalanche block.

Disaggregation and mixing of debris-avalanche blocks of the block facies were both important processes during the initiation and transport of the debris avalanche. Window types 1 to 3 show little or no mixing, and types 4 to 7 show progressively greater amounts of mixing. The presence of more than one rock type in window types 4 to 6 suggests that there may be more than one debris-avalanche block in each square meter. In these windows, it is apparent that as the avalanche was moving, some of the debris-avalanche blocks disaggregated into their constituent clasts that were mixed together with clasts from other debris-avalanche blocks; this was one of the processes that created the matrix facies present in window types 5,6 , and 7 . This process is well illustrated by windows DXS-9 and DXS31 (Fig. 50); these exposures consist almost entirely of matrix facies with only a few rubble schlieren of the block facies remaining. The material stopped moving just before mixing was complete.

Breaking up and mixing of the debris-avalanche blocks in the block facies were not the only processes that created the matrix facies. Clasts of juvenile dacite are characteristic of the matrix facies (table 3), yet no debris-avalanche blocks of juvenile dacite are found in the avalanche deposit. This suggests that masses of juvenile dacite explosively broke apart immediately upon depressurization of the cryptodome. Eyewitness photographs (Voight, 1981) show that explosions burst through slide blocks II and III, mixing pre-1980 rocks with the juvenile dacite. The photographs indicate that the explosions from slide block II created the "blast surge" that spread over the ridges north of the mountain. The explosions that accompanied slide block III were probably less energetic, and the debris from these explosions may have picked up pieces of previously deposited debris avalanche blocks which then disaggregated. The whole mass moved down the North Fork Toutle River valley and was deposited as the matrix facies.

The roughly horizontal stratification of some of the windows may represent original stratigraphy from the mountain or may result from shear within the debris avalanche. If horizontal stratification represents original stratigraphy, it implies that debris-avalanche blocks may have rotated about vertical axes but did not tumble endover-end during transport. This is consistent with the results of Mimura and Kawachi (1981) and Mimura and others (1982) for the Nirasaki volcanic "dry" avalanche deposit. They found that the inclinations of natural remnant magnetism (NRM) in debris-avalanche blocks of the Nirasaki deposit are similar to one another and generally close to the present magnetic field, but that the declinations are quite different from one another.

Roughly horizontal stratification probably generally results from shear within the moving avalanche. The stratigraphy within windows generally cannot be recognized as original volcanic stratigraphy. Greater shear takes place at the margins of avalanche flow rather than at the center, and windows at the margins of the deposit 
commonly exhibit crudely horizontal stratification (e.g., windows 827-7, DXS-26, and DXS-28; fig. 50).

The coherent but deformed debris-avalanche blocks in exposure types 3 to 6 are characteristic of many volcanic debris avalanches around the world (Ui, 1983) and serve as good criteria for recognition of this kind of deposit. Deposits of other poorly-sorted volcaniclastic materials only very rarely show these structures on the scale of the windows. Where they do, it is likely that the blocks were picked up from a pre-existing debris-avalanche deposit and carried "gently" in a lahar or pyroclastic flow (for example, Scott, 1988, 1989).

As type 7 windows are identical in appearance to many unsorted and unstratified exposures of the blast deposit they cannot provide criteria with which to recognize debris-avalanche deposits. They are only recognized as exposures of the Mount St. Helens debris-avalanche deposit because they are found in hummocks of the deposit.

\section{DENSITY MEASUREMENTS}

To quantify the measure of degree of disaggregation of the debris-avalanche deposit, the density of the deposit and the mountain were determined (table 4). The inplace dry field density of the debris-avalanche deposit was measured by the standard sand-cone test (American Society for Testing of Materials, 1977) on a cleared flat area adjacent to each window (fig. 51A). Similar sandcone density measurements were made at three locations in the older dacite dome complex in the crater walls and at one location in an older dacite pyroclastic-flow deposit in a canyon on the north flank of the mountain. It is not possible to apply the sand-cone technique to the coarse lava flows that make up the bulk of the andesite and basalt unit, so laboratory-determined specific gravity measurements of andesite and basalt clasts $>2 \mathrm{~cm}$ diameter were assumed to represent the density of the andesite and basalt unit. Laboratory-determined specific gravity measurements of modern dacite clasts $>2 \mathrm{~cm}$ diameter were assumed to represent the density of the modern dacite unit which is missing from the crater. The density of the least vesiculated juvenile dacite clasts (Hoblitt and others, 1981; Hoblitt and Harmon, 1993) were assumed to approximate the density of the cryptodome.

The mean density of the part of the mountain that became the debris avalanche is calculated to be $2.31 \mathrm{~g} /$ $\mathrm{cm}^{3}$. The percentages of the various rock types in the crater (table 2) and density measurements for each rock type in the old mountain (table 4) are used to compute this value. Sand-cone dry density measurements of the older dacite unit in the mountain range from 2.41 to 2.53 $\mathrm{g} / \mathrm{cm}^{3}$ with a mean of $2.44 \mathrm{~g} / \mathrm{cm}^{3}$. Laboratory dry-density measurements of andesite and basalt clasts, each representing the average of about 50 clasts of varying vesicularity, average $2.22 \mathrm{~g} / \mathrm{cm}^{3}$; similar measurements of modern dacite clasts average $2.27 \mathrm{~g} / \mathrm{cm}^{3}$. The laboratory measurements may be slightly higher than the actual densities of the units because they ignore jointing in the units on the old mountain. The density of the least vesiculated juvenile dacite is 2.0 to $2.1 \mathrm{~g} / \mathrm{cm}^{3}$ (Hoblitt and others, 1981).

Sand-cone measurements of the debris-avalanche deposit range from 1.44 to $2.18 \mathrm{~g} / \mathrm{cm}^{3}$ and have a mean value of $1.85 \mathrm{~g} / \mathrm{cm}^{3}$ (table 4). Just before deposition, the debris avalanche at each sample locality was probably slightly less dense than the measured value, so the data represent maximum density values for the moving debris avalanche. The mean measured values of the older dacite, andesite and basalt, modern dacite, and mixed units vary within a narrow range of 1.89 to $1.99 \mathrm{~g} / \mathrm{cm}^{3}$. The units that are present only on the margins of the deposit, the modern undifferentiated and the marginal mixed block and matrix facies unit, have significantly lower (1.60 and $\left.1.61 \mathrm{~g} / \mathrm{cm}^{3}\right)$ mean density values than the rest of the deposit (table 4; fig. 51B).

The mean density of the samples from debris avalanche $\left(1.85 \mathrm{~g} / \mathrm{cm}^{3}\right)$ is significantly less than the calculated mean density of the old mountain $\left(2.31 \mathrm{~g} / \mathrm{cm}^{3}\right)$. In fact, all the density measurements of the debris-avalanche deposit are significantly less than all the measurements of the material making up the old mountain. This suggests that during the events of blast and the rockslide-debris avalanche, the material from the mountain was dilated by about 20 percent before the bulk of it was deposited as the debris-avalanche deposit.

There are no trends of increasing or decreasing density with distance from source (fig. $51 B$ ). A decreasing trend would be expected if dilation resulted primarily from transport of the material in the debris avalanche or shear within the avalanche. The lack of this trend suggests that processes that occurred at the mountain were the most important processes that shattered and dilated the material. However, the lower density values for the two units present at the margins of the deposit suggest that shear at the margins of flow contributed to dilation.

Dilation probably resulted, at least in part, from shattering of clasts. Shattering of clasts is evident in the windows of type 1 and 2. The Mount St. Helens' deposit may be more thoroughly shattered than most other large volcanic debris-avalanche deposits and that may explain the scarcity of jigsaw cracks in the Mount St. Helens' deposit compared with other large volcanic debris avalanche deposits. The causes of dilation and shattering are explained in the "Conclusions". 
Table 4. Distance from source, density, grain-size, and sorting parameters for debris-avalanche and blast deposits

[distsr, distance from source (assumed to be the site of the 1980-85 dome) in km; denco, density of coarse clasts measured for some samples and assumed for others to be average of measured samples for each unit, in $\mathrm{g} / \mathrm{cm}^{3}$; denfld, field density computed by sand-cone method, in $\mathrm{g} / \mathrm{cm}^{3}$; pct, percentage; gr, gravel; sa, sand; si, silt, cl, clay; mu, mud (silt+clay); fw, Folk and Ward (1957); in, Inman (1954); tr, Trask (1930); mom, moment statistics; md, median; mn, mean; so, sorting; sk, skewness; ku, kurtosis; stand dev, standard deviation; Sprt, at Spirit Lake, Cold, at Coldwater Lake; Cstl, at Castle Lake]

\begin{tabular}{|c|c|c|c|c|c|c|c|c|c|c|c|c|c|}
\hline Sample & distsr & denco & denfld & pctgr & pctsa & pctsi & pctcl & pctmu & mommn & momso & fwmd & fwmn & fwso \\
\hline \multicolumn{14}{|c|}{ Older dacite unit } \\
\hline$\overline{\mathrm{DXS}-2}$ & 25.30 & 1.97 & 2.43 & 59.06 & 32.65 & 7.54 & 0.75 & 8.29 & -1.57 & 3.86 & -2.24 & -1.71 & 3.92 \\
\hline DXS-4 & 15.10 & 2.07 & 2.43 & 37.22 & 51.44 & 10.32 & 1.02 & 11.34 & 0.19 & 3.46 & 0.41 & -0.02 & 3.39 \\
\hline DXS-6 & 15.60 & 2.04 & 2.39 & 52.65 & 43.74 & 3.21 & 0.40 & 3.61 & -0.99 & 2.74 & -1.17 & -0.98 & 2.65 \\
\hline DXS-20 & 12.30 & 2.08 & 2.39 & 21.98 & 60.62 & 14.78 & 2.61 & 17.39 & 1.32 & 3.13 & 1.00 & 1.24 & 2.84 \\
\hline DXS-21 & 18.40 & 2.15 & 2.39 & 40.52 & 47.53 & 10.64 & 1.31 & 11.95 & -0.18 & 3.86 & 0.04 & -0.27 & 3.85 \\
\hline DXS-22 & 17.60 & 1.93 & 2.39 & 48.61 & 39.05 & 11.23 & 1.11 & 12.34 & -0.64 & 3.95 & -0.82 & -0.75 & 3.97 \\
\hline DXS-24 & 13.30 & 1.86 & 2.39 & 22.81 & 65.41 & 10.13 & 1.65 & 11.78 & 1.04 & 2.72 & 0.84 & 0.83 & 2.55 \\
\hline 825-3(Sprt) & 9.40 & 1.75 & 2.43 & 23.83 & 55.01 & 17.78 & 3.39 & 21.16 & 1.45 & 3.94 & 1.81 & 1.50 & 3.84 \\
\hline 827-3(Sprt) & 9.70 & 1.98 & 2.43 & 24.00 & 60.50 & 13.64 & 1.86 & 15.50 & 1.11 & 3.10 & 0.96 & 0.92 & 3.01 \\
\hline MS-10(Cold) & 16.90 & 1.61 & 2.43 & 30.40 & 55.80 & 12.28 & 1.52 & 13.80 & 0.80 & 3.10 & 0.80 & 0.64 & 3.06 \\
\hline 826-3(Cstl) & 16.40 & 1.45 & 2.43 & 37.95 & 52.24 & 8.92 & 0.88 & 9.81 & 0.20 & 3.12 & 0.25 & 0.02 & 3.12 \\
\hline mean & 15.45 & 1.90 & 2.41 & 36.28 & 51.27 & 10.95 & 1.50 & 12.45 & 0.25 & 3.36 & 0.17 & 0.13 & 3.29 \\
\hline stan dev & 4.45 & 0.22 & 0.02 & 12.99 & 9.87 & 3.84 & 0.87 & 4.64 & 1.00 & 0.47 & 1.16 & 1.00 & 0.53 \\
\hline \multicolumn{14}{|c|}{ Andesite and basalt unit } \\
\hline$\overline{\mathrm{DXS}-11}$ & 13.50 & 2.13 & 2.27 & 49.35 & 46.05 & 4.37 & 0.23 & 4.60 & -1.06 & 2.95 & -0.94 & -1.11 & 2.81 \\
\hline DXS-13 & 2.50 & 2.13 & 2.27 & 41.23 & 52.49 & 5.52 & 0.75 & 6.28 & -0.49 & 3.21 & -0.16 & -0.59 & 3.16 \\
\hline DXS-14 & 2.70 & 1.97 & 2.27 & 48.05 & 45.66 & 5.72 & 0.57 & 6.29 & -0.61 & 2.95 & -0.82 & -0.75 & 2.85 \\
\hline DXS-16 & 11.30 & 2.07 & 2.27 & 56.86 & 34.34 & 8.00 & 0.79 & 8.80 & -1.19 & 3.58 & -1.78 & -1.14 & 3.50 \\
\hline DXS-23 & 13.00 & 1.66 & 2.27 & 50.81 & 43.52 & 5.39 & 0.28 & 5.67 & -0.87 & 3.03 & -1.06 & -0.96 & 3.01 \\
\hline DXS-25 & 14.60 & 1.86 & 2.27 & 65.15 & 30.12 & 4.21 & 0.52 & 4.73 & -2.14 & 3.43 & -2.58 & -2.29 & 3.39 \\
\hline DXS-27 & 17.70 & 2.08 & 2.27 & 27.83 & 59.17 & 11.05 & 1.95 & 13.00 & 0.71 & 3.53 & 1.08 & 0.63 & 3.38 \\
\hline DXS-38 & 29.70 & 1.77 & 2.27 & 47.78 & 45.47 & 6.01 & 0.74 & 6.75 & -0.93 & 3.39 & -0.86 & -0.90 & 3.47 \\
\hline $825-5$ (Sprt) & 9.40 & 1.84 & 2.27 & 69.08 & 29.29 & 1.48 & 0.15 & 1.63 & -2.31 & 2.93 & -3.00 & -2.27 & 2.94 \\
\hline 827-2(Sprt) & 10.60 & 1.82 & 2.27 & 66.62 & 28.71 & 4.15 & 0.51 & 4.67 & -2.46 & 3.64 & -3.41 & -2.76 & 3.68 \\
\hline MS-9(Cold) & 16.90 & 1.53 & 2.27 & 47.92 & 41.08 & 9.57 & 1.43 & 11.00 & -0.80 & 4.04 & -0.69 & -0.81 & 4.00 \\
\hline mean & 12.90 & 1.90 & 2.27 & 51.88 & 41.45 & 5.95 & 0.72 & 6.67 & -1.10 & 3.33 & -1.29 & -1.18 & 3.29 \\
\hline stan dev & 7.46 & 0.20 & 0.00 & 12.09 & 9.92 & 2.69 & 0.54 & 3.20 & 0.92 & 0.36 & 1.31 & 0.95 & 0.37 \\
\hline \multicolumn{14}{|c|}{ Modern dacite unit } \\
\hline$\overline{\mathrm{DXS}-3}$ & 15.70 & 1.85 & 2.22 & 61.01 & 31.59 & 6.37 & 1.04 & 7.40 & -2.04 & 4.13 & -2.71 & -2.20 & 4.15 \\
\hline DXS-12 & 13.50 & 1.85 & 2.22 & 92.34 & 6.56 & 1.01 & 0.09 & 1.09 & -5.58 & 2.66 & -6.51 & -5.87 & 2.33 \\
\hline DXS-19 & 11.70 & 2.13 & 2.22 & 53.63 & 38.12 & 7.51 & 0.74 & 8.25 & -0.74 & 3.42 & -1.49 & -0.88 & 3.25 \\
\hline MS-1(Cold) & 17.20 & 2.12 & 2.22 & 48.03 & 41.14 & 9.20 & 1.62 & 10.83 & -0.48 & 3.72 & -0.76 & -0.56 & 3.58 \\
\hline mean & 14.53 & 1.99 & 2.22 & 63.75 & 29.35 & 6.02 & 0.87 & 6.89 & -2.21 & 3.48 & -2.87 & -2.38 & 3.33 \\
\hline stan dev & 2.42 & 0.16 & 0.00 & 19.79 & 15.71 & 3.54 & 0.64 & 4.13 & 2.35 & 0.62 & 2.56 & 2.43 & 0.76 \\
\hline
\end{tabular}


Table 4. Distance from source, density, grain-size, and sorting parameters for debris-avalanche and blast deposits--Continued

\begin{tabular}{|c|c|c|c|c|c|c|c|c|c|c|c|c|c|}
\hline Sample & fwsk & fwku & inmd & inmn & inso & insk1 & insk2 & inku & trmd & trmn & trso & trsk & trku \\
\hline \multicolumn{14}{|c|}{ Older dacite unit } \\
\hline$\overline{\mathrm{DXS}}-2$ & 0.19 & 0.89 & -2.24 & -1.45 & 4.12 & 0.19 & 0.29 & 0.49 & 4.71 & 10.71 & 7.15 & 0.39 & 0.12 \\
\hline DXS-4 & -0.07 & 0.82 & 0.41 & -0.24 & 3.57 & -0.18 & 0.06 & 0.48 & 0.75 & 3.54 & 6.30 & 2.12 & 0.16 \\
\hline DXS-6 & 0.04 & 1.17 & -1.17 & -0.89 & 2.43 & 0.11 & -0.06 & 0.95 & 2.25 & 3.39 & 3.16 & 0.75 & 0.23 \\
\hline DXS-20 & 0.11 & 0.98 & 1.00 & 1.36 & 2.86 & 0.12 & 0.14 & 0.63 & 0.50 & 0.91 & 3.87 & 0.78 & 0.17 \\
\hline DXS-21 & -0.09 & 0.90 & 0.04 & -0.43 & 3.86 & -0.12 & -0.10 & 0.64 & 0.97 & 4.81 & 7.40 & 1.72 & 0.12 \\
\hline DXS-22 & 0.05 & 0.86 & -0.82 & -0.72 & 4.18 & 0.02 & 0.11 & 0.48 & 1.76 & 6.24 & 7.83 & 0.79 & 0.11 \\
\hline DXS-24 & 0.07 & 1.05 & 0.84 & 0.83 & 2.56 & 0.00 & 0.24 & 0.63 & 0.56 & 0.95 & 3.11 & 0.97 & 0.18 \\
\hline $825-3$ (Sprt) & -0.18 & 1.22 & 1.81 & 1.34 & 3.70 & -0.13 & -0.41 & 0.77 & 0.29 & 0.91 & 4.57 & 1.79 & 0.07 \\
\hline $827-3$ (Sprt) & 0.01 & 1.01 & 0.96 & 0.90 & 3.04 & -0.02 & 0.07 & 0.62 & 0.51 & 1.00 & 3.97 & 0.84 & 0.11 \\
\hline MS-10(Cold) & -0.01 & 0.93 & 0.80 & 0.55 & 3.14 & -0.08 & 0.09 & 0.57 & 0.57 & 1.55 & 4.47 & 1.33 & 0.15 \\
\hline 826-3(Cstl) & -0.03 & 0.85 & 0.25 & -0.09 & 3.26 & -0.10 & 0.07 & 0.51 & 0.84 & 2.74 & 5.21 & 1.45 & 0.17 \\
\hline mean & 0.01 & 0.97 & 0.17 & 0.11 & 3.34 & -0.02 & 0.05 & 0.62 & 1.25 & 3.34 & 5.19 & 1.18 & 0.14 \\
\hline stan dev & 0.10 & 0.13 & 1.16 & 0.95 & 0.60 & 0.12 & 0.19 & 0.14 & 1.29 & 3.02 & 1.72 & 0.54 & 0.04 \\
\hline \multicolumn{14}{|c|}{ Andesite and basalt unit } \\
\hline DXS-11 & 0.03 & 0.77 & -0.94 & -1.19 & 3.06 & -0.08 & 0.19 & 0.39 & 1.92 & 6.34 & 4.82 & 1.72 & 0.24 \\
\hline DXS-13 & -0.14 & 0.89 & -0.16 & -0.81 & 3.25 & -0.20 & -0.13 & 0.56 & 1.11 & 4.21 & 5.06 & 2.07 & 0.15 \\
\hline DXS-14 & 0.11 & 0.85 & -0.82 & -0.71 & 2.97 & 0.04 & 0.27 & 0.51 & 1.77 & 4.09 & 4.51 & 0.95 & 0.20 \\
\hline DXS-16 & 0.24 & 0.83 & -1.78 & -0.82 & 3.64 & 0.26 & 0.32 & 0.52 & 3.43 & 8.28 & 6.68 & 0.50 & 0.23 \\
\hline DXS-23 & 0.08 & 0.87 & -1.06 & -0.91 & 3.18 & 0.05 & 0.17 & 0.47 & 2.08 & 4.52 & 4.64 & 0.80 & 0.13 \\
\hline DXS-25 & 0.15 & 0.98 & -2.58 & -2.14 & 3.40 & 0.13 & 0.27 & 0.63 & 5.99 & 11.69 & 4.98 & 0.57 & 0.12 \\
\hline DXS-27 & -0.19 & 1.10 & 1.08 & 0.40 & 3.24 & -0.21 & -0.31 & 0.79 & 0.47 & 1.39 & 4.47 & 1.57 & 0.07 \\
\hline DXS-38 & -0.06 & 1.06 & -0.86 & -0.92 & 3.31 & -0.02 & -0.19 & 0.82 & 1.82 & 5.52 & 5.01 & 1.36 & 0.16 \\
\hline $825-5$ (Sprt) & 0.30 & 0.95 & -3.00 & -1.90 & 2.98 & 0.37 & 0.36 & 0.61 & 7.99 & 10.57 & 4.22 & 0.35 & 0.24 \\
\hline $827-2$ (Sprt) & 0.27 & 1.06 & -3.41 & -2.44 & 3.96 & 0.25 & 0.42 & 0.42 & 10.62 & 9.02 & 4.53 & 0.13 & 0.07 \\
\hline MS-9(Cold) & -0.03 & 0.90 & -0.69 & -0.86 & 4.04 & -0.04 & -0.04 & 0.62 & 1.62 & 7.61 & 7.85 & 1.39 & 0.08 \\
\hline mean & 0.07 & 0.93 & -1.29 & -1.12 & 3.37 & 0.05 & 0.12 & 0.58 & 3.53 & 6.66 & 5.16 & 1.04 & 0.15 \\
\hline stan dev & 0.16 & 0.11 & 1.31 & 0.79 & 0.37 & 0.19 & 0.25 & 0.14 & 3.25 & 3.10 & 1.10 & 0.63 & 0.07 \\
\hline \multicolumn{14}{|c|}{ Modern dacite unit } \\
\hline$\overline{\mathrm{DXS}-3}$ & 0.16 & 0.89 & -2.71 & -1.94 & 4.19 & 0.18 & 0.21 & 0.62 & 6.55 & 17.74 & 8.67 & 0.38 & 0.12 \\
\hline DXS-12 & 0.55 & 1.53 & -6.51 & -5.54 & 2.17 & 0.45 & 1.23 & 0.89 & 91.28 & 108.24 & 2.14 & 0.83 & 0.31 \\
\hline DXS-19 & 0.28 & 0.71 & -1.49 & -0.58 & 3.48 & 0.26 & 0.42 & 0.44 & 2.80 & 6.43 & 7.32 & 0.38 & 0.29 \\
\hline MS-1(Cold) & 0.11 & 0.86 & -0.76 & -0.47 & 3.64 & 0.08 & 0.21 & 0.60 & 1.69 & 5.63 & 6.78 & 0.92 & 0.20 \\
\hline mean & 0.28 & 1.00 & -2.87 & -2.13 & 3.37 & 0.24 & 0.52 & 0.64 & 25.58 & 34.51 & 6.23 & 0.63 & 0.23 \\
\hline stan dev & 0.20 & 0.36 & 2.56 & 2.37 & 0.86 & 0.16 & 0.49 & 0.19 & 43.85 & 49.46 & 2.84 & 0.29 & 0.09 \\
\hline
\end{tabular}


Table 4. Distance from source, density, grain-size, and sorting parameters for debris-avalanche and blast--Continued

\begin{tabular}{|c|c|c|c|c|c|c|c|c|c|c|c|c|c|}
\hline Sample & distsr & denco & denfld & pctgr & pctsa & pctsi & pctcl & pctmu & mommn & momso & fwmd & fwmn & fwso \\
\hline \multicolumn{14}{|c|}{ Modern undifferentiated unit } \\
\hline$\overline{\mathrm{DXS}-17}$ & 12.40 & 1.96 & 2.25 & 55.49 & 31.22 & 12.49 & 0.80 & 13.29 & -0.71 & 3.68 & -1.71 & -0.74 & 3.60 \\
\hline 826-2(Cstl) & 16.20 & 1.51 & 2.25 & 43.47 & 46.75 & 8.80 & 0.98 & 9.78 & -0.31 & 3.40 & -0.36 & -0.43 & 3.38 \\
\hline 827-6(Cstl) & 15.90 & 1.44 & 2.25 & 46.73 & 43.73 & 8.59 & 0.95 & 9.55 & -0.82 & 4.08 & -0.49 & -0.65 & 3.99 \\
\hline $827-7(\mathrm{Cstl})$ & 15.90 & 1.50 & 2.25 & 45.91 & 41.55 & 11.16 & 1.38 & 12.54 & -0.27 & 3.76 & -0.38 & -0.39 & 3.74 \\
\hline mean & 15.10 & 1.60 & 2.25 & 47.90 & 40.81 & 10.26 & 1.03 & 11.29 & -0.53 & 3.73 & -0.74 & -0.55 & 3.68 \\
\hline stan dev & 1.81 & 0.24 & 0.00 & 5.25 & 6.74 & 1.89 & 0.25 & 1.90 & 0.28 & 0.28 & 0.65 & 0.17 & 0.26 \\
\hline \multicolumn{14}{|c|}{ Mixed block and matrix facies unit } \\
\hline$\overline{\mathrm{DXS}-1}$ & 29.90 & 1.99 & 2.30 & 42.89 & 43.52 & 12.36 & 1.22 & 13.58 & -0.12 & 3.88 & -0.05 & -0.21 & 3.88 \\
\hline DXS-8 & 25.80 & 1.76 & 2.30 & 41.53 & 51.23 & 6.52 & 0.72 & 7.24 & -0.18 & 3.15 & -0.12 & -0.32 & 3.07 \\
\hline DXS-29 & 21.40 & 1.81 & 2.30 & 47.93 & 42.83 & 7.67 & 1.57 & 9.24 & -0.75 & 3.81 & -0.71 & -0.78 & 3.75 \\
\hline DXS-30 & 22.20 & 1.96 & 2.26 & 41.26 & 48.11 & 9.26 & 1.38 & 10.64 & -0.20 & 3.52 & -0.03 & -0.22 & 3.51 \\
\hline DXS-31 & 23.10 & 2.10 & 2.30 & 35.72 & 54.97 & 8.10 & 1.21 & 9.31 & 0.20 & 3.21 & 0.43 & 0.06 & 3.12 \\
\hline DXS-33 & 24.50 & 2.18 & 2.30 & 46.33 & 45.30 & 7.62 & 0.75 & 8.38 & -0.70 & 3.64 & -0.60 & -0.76 & 3.63 \\
\hline DXS-34 & 26.80 & 1.77 & 2.39 & 36.96 & 51.07 & 10.41 & 1.56 & 11.97 & 0.15 & 3.47 & 0.26 & -0.04 & 3.39 \\
\hline DXS-35 & 28.10 & 1.80 & 2.30 & 51.04 & 41.57 & 6.64 & 0.74 & 7.38 & -0.96 & 3.64 & -1.15 & -0.94 & 3.53 \\
\hline DXS-36 & 31.20 & 1.68 & 2.30 & 39.07 & 53.76 & 6.53 & 0.65 & 7.17 & -0.20 & 3.31 & 0.08 & -0.31 & 3.32 \\
\hline DXS-37 & 30.70 & 1.90 & 2.30 & 35.32 & 51.88 & 10.62 & 2.17 & 12.79 & 0.29 & 3.57 & 0.34 & 0.06 & 3.46 \\
\hline mean & 26.37 & 1.89 & 2.31 & 41.81 & 48.42 & 8.57 & 1.20 & 9.77 & -0.25 & 3.52 & -0.16 & -0.35 & 3.47 \\
\hline stan dev & 3.56 & 0.16 & 0.03 & 5.32 & 4.83 & 2.01 & 0.49 & 2.37 & 0.43 & 0.24 & 0.51 & 0.36 & 0.26 \\
\hline \multicolumn{14}{|c|}{ Marginal mixed block and matrix facies unit } \\
\hline DXS-9 & 21.70 & 1.77 & 2.30 & 46.10 & 44.35 & 8.60 & 0.96 & 9.55 & -0.72 & 3.89 & -0.45 & -0.71 & 3.86 \\
\hline DXS-26 & 17.70 & 1.57 & 2.30 & 40.70 & 48.40 & 10.02 & 0.87 & 10.90 & -0.15 & 3.47 & 0.06 & -0.27 & 3.44 \\
\hline DXS-28 & 21.00 & 1.45 & 2.30 & 47.70 & 41.10 & 10.19 & 1.01 & 11.19 & -0.44 & 3.59 & -0.63 & -0.48 & 3.47 \\
\hline DXS-32 & 23.60 & 1.66 & 2.30 & 34.24 & 51.55 & 12.51 & 1.70 & 14.21 & 0.29 & 3.90 & 0.83 & 0.31 & 3.85 \\
\hline mean & 21.00 & 1.61 & 2.30 & 42.19 & 46.35 & 10.33 & 1.13 & 11.46 & -0.26 & 3.71 & -0.05 & -0.29 & 3.65 \\
\hline stan dev & 2.46 & 0.14 & 0.00 & 6.08 & 4.58 & 1.62 & 0.38 & 1.97 & 0.43 & 0.22 & 0.65 & 0.44 & 0.23 \\
\hline \multicolumn{14}{|c|}{ All of debris avalanche deposit } \\
\hline mean & 17.68 & 1.85 & 2.31 & 45.53 & 44.78 & 8.59 & 1.10 & 9.70 & -0.54 & 3.47 & -0.65 & -0.63 & 3.40 \\
\hline stan dev & 6.96 & 0.22 & 0.07 & 13.37 & 10.62 & 3.41 & 0.65 & 3.98 & 1.18 & 0.39 & 1.45 & 1.20 & 0.43 \\
\hline \multicolumn{14}{|c|}{ Blast deposit } \\
\hline$\overline{\text { DXS-5 }}$ & 13.40 & 1.82 & 2.18 & 32.73 & 54.70 & 11.19 & 1.38 & 12.58 & 0.68 & 3.27 & 0.82 & 0.53 & 3.12 \\
\hline DXS-18 & 11.50 & 2.21 & 2.18 & 42.09 & 48.94 & 7.89 & 1.08 & 8.97 & -0.23 & 3.49 & 0.00 & -0.37 & 3.38 \\
\hline $826-4(\mathrm{Cstl})$ & 16.60 & 2.02 & 2.18 & 30.68 & 52.74 & 14.09 & 2.49 & 16.58 & 0.94 & 3.64 & 1.23 & 0.78 & 3.39 \\
\hline mean & 13.83 & 2.02 & 2.18 & 35.17 & 52.13 & 11.06 & 1.65 & 12.71 & 0.46 & 3.47 & 0.68 & 0.31 & 3.30 \\
\hline stan dev & 2.58 & 0.20 & 0.00 & 6.08 & 2.93 & 3.10 & 0.74 & 3.81 & 0.61 & 0.19 & 0.63 & 0.60 & 0.15 \\
\hline
\end{tabular}


Table 4. Distance from source, density, grain-size, and sorting parameters for debris-avalanche and blast deposits--Continued

\begin{tabular}{|c|c|c|c|c|c|c|c|c|c|c|c|c|c|}
\hline Sample & fwsk & fwku & inmd & inmn & inso & insk1 & insk2 & inku & trmd & trmn & trso & trsk & trku \\
\hline \multicolumn{14}{|c|}{ Modern undifferentiated unit } \\
\hline DXS-17 & 0.35 & 0.73 & -1.71 & -0.26 & 3.89 & 0.37 & 0.45 & 0.41 & 3.26 & 6.79 & 8.43 & 0.24 & 0.27 \\
\hline 826-2(Cstl) & 0.01 & 0.83 & -0.36 & -0.46 & 3.59 & -0.03 & 0.07 & 0.45 & 1.28 & 4.30 & 6.02 & 1.18 & 0.23 \\
\hline 827-6(Cstl) & -0.12 & 0.95 & -0.49 & -0.73 & 3.87 & -0.06 & -0.31 & 0.75 & 1.41 & 6.39 & 7.66 & 1.36 & 0.06 \\
\hline 827-7(Cstl) & 0.02 & 0.82 & -0.38 & -0.40 & 3.84 & -0.01 & 0.09 & 0.56 & 1.30 & 5.85 & 8.02 & 1.22 & 0.22 \\
\hline mean & 0.06 & 0.83 & -0.74 & -0.46 & 3.80 & 0.07 & 0.07 & 0.54 & 1.81 & 5.83 & 7.53 & 1.00 & 0.20 \\
\hline stan dev & 0.20 & 0.09 & 0.65 & 0.20 & 0.14 & 0.20 & 0.31 & 0.15 & 0.97 & 1.09 & 1.06 & 0.51 & 0.09 \\
\hline \multicolumn{14}{|c|}{ Mixed block and matrix facies unit } \\
\hline$\overline{\text { DXS-1 }}$ & -0.05 & 0.86 & -0.05 & -0.29 & 3.92 & -0.06 & -0.07 & 0.62 & 1.04 & 5.12 & 8.09 & 1.45 & 0.26 \\
\hline DXS-8 & -0.03 & 0.79 & -0.12 & -0.42 & 3.29 & -0.09 & 0.04 & 0.43 & 1.08 & 3.50 & 5.46 & 1.31 & 0.20 \\
\hline DXS-29 & -0.02 & 0.88 & -0.71 & -0.82 & 3.75 & -0.03 & -0.01 & 0.65 & 1.63 & 7.53 & 7.31 & 1.54 & 0.21 \\
\hline DXS-30 & -0.06 & 0.95 & -0.03 & -0.31 & 3.45 & -0.08 & -0.08 & 0.71 & 1.02 & 4.23 & 5.90 & 1.87 & 0.18 \\
\hline DXS-31 & -0.11 & 0.92 & 0.43 & -0.13 & 3.21 & -0.18 & -0.07 & 0.56 & 0.74 & 2.39 & 4.70 & 1.72 & 0.13 \\
\hline DXS-33 & -0.06 & 0.93 & -0.60 & -0.84 & 3.62 & -0.07 & -0.09 & 0.66 & 1.51 & 5.41 & 6.26 & 1.24 & 0.10 \\
\hline DXS-34 & -0.03 & 0.88 & 0.26 & -0.19 & 3.54 & -0.13 & 0.09 & 0.50 & 0.83 & 3.25 & 5.60 & 1.82 & 0.18 \\
\hline DXS-35 & 0.06 & 0.82 & -1.15 & -0.84 & 3.56 & 0.09 & 0.04 & 0.62 & 2.22 & 7.78 & 7.45 & 0.86 & 0.21 \\
\hline DXS-36 & -0.15 & 0.84 & 0.08 & -0.51 & 3.49 & -0.17 & -0.20 & 0.49 & 0.95 & 3.67 & 5.81 & 1.68 & 0.13 \\
\hline DXS-37 & -0.03 & 0.94 & 0.34 & -0.08 & 3.57 & -0.12 & 0.08 & 0.55 & 0.79 & 2.67 & 5.34 & 1.49 & 0.12 \\
\hline mean & -0.05 & 0.88 & -0.16 & -0.44 & 3.54 & -0.08 & -0.03 & 0.58 & 1.18 & 4.55 & 6.19 & 1.50 & 0.17 \\
\hline stan dev & 0.06 & 0.05 & 0.51 & 0.30 & 0.20 & 0.08 & 0.09 & 0.09 & 0.47 & 1.89 & 1.08 & 0.31 & 0.05 \\
\hline \multicolumn{14}{|c|}{ Marginal mixed block and matix facies unit } \\
\hline DXS-9 & -0.09 & 0.87 & -0.45 & -0.85 & 3.88 & -0.10 & -0.13 & 0.63 & 1.36 & 7.37 & 7.79 & 1.86 & 0.09 \\
\hline DXS-26 & -0.05 & 0.80 & 0.06 & -0.43 & 3.66 & -0.14 & 0.05 & 0.45 & 0.96 & 4.70 & 6.57 & 2.14 & 0.19 \\
\hline DXS-28 & 0.11 & 0.79 & -0.63 & -0.41 & 3.64 & 0.06 & 0.23 & 0.49 & 1.55 & 5.77 & 7.07 & 1.06 & 0.25 \\
\hline DXS-32 & -0.22 & 1.05 & 0.83 & 0.05 & 3.71 & -0.21 & -0.40 & 0.77 & 0.56 & 2.56 & 5.97 & 2.19 & 0.05 \\
\hline mean & -0.06 & 0.88 & -0.05 & -0.41 & 3.72 & -0.10 & -0.06 & 0.58 & 1.11 & 5.10 & 6.85 & 1.81 & 0.14 \\
\hline stan dev & 0.14 & 0.12 & 0.65 & 0.37 & 0.11 & 0.11 & 0.27 & 0.15 & 0.44 & 2.02 & 0.77 & 0.52 & 0.09 \\
\hline \multicolumn{14}{|c|}{ All of debris avalanche deposit } \\
\hline mean & 0.03 & 0.92 & -0.65 & -0.63 & 3.47 & 0.01 & 0.08 & 0.59 & 4.05 & 7.67 & 5.87 & 1.21 & 0.17 \\
\hline stan dev & 0.16 & 0.14 & 1.45 & 1.10 & 0.45 & 0.17 & 0.27 & 0.13 & 13.62 & 15.86 & 1.59 & 0.56 & 0.07 \\
\hline \multicolumn{14}{|c|}{ Blast deposit } \\
\hline $\begin{array}{l}\text { DXS-5 } \\
\end{array}$ & -0.07 & 0.91 & 0.82 & 0.38 & 3.16 & -0.14 & 0.02 & 0.61 & 0.57 & 1.82 & 4.95 & 1.56 & 0.15 \\
\hline DXS-18 & -0.09 & 0.77 & 0.00 & -0.56 & 3.58 & -0.16 & -0.02 & 0.47 & 1.00 & 5.01 & 6.94 & 2.01 & 0.19 \\
\hline 826-4(Cstl) & -0.13 & 0.86 & 1.23 & 0.55 & 3.56 & -0.19 & -0.10 & 0.49 & 0.43 & 1.98 & 5.81 & 2.43 & 0.16 \\
\hline mean & -0.10 & 0.85 & 0.68 & 0.12 & 3.43 & -0.16 & -0.03 & 0.52 & 0.67 & 2.94 & 5.90 & 2.00 & 0.17 \\
\hline stan dev & 0.03 & 0.07 & 0.63 & 0.60 & 0.24 & 0.03 & 0.06 & 0.08 & 0.30 & 1.80 & 1.00 & 0.44 & 0.02 \\
\hline
\end{tabular}


Table 4. Distance from source, density, grain-size, and sorting parameters for debris-avalanche and blast deposits--Continued

\begin{tabular}{|c|c|c|c|c|c|c|c|c|c|c|c|c|c|}
\hline Sample & distsr & denco & denfld & pctgr & pctsa & pctsi & pctcl & pctmu & mommn & momso & fwmd & fwmn & fwso \\
\hline \multicolumn{14}{|c|}{ Old mountain clastics } \\
\hline$\overline{\mathrm{DXS}-15}$ & 0.00 & 2.41 & 2.39 & 83.95 & 14.02 & 1.89 & 0.14 & 2.03 & -3.65 & 2.88 & -4.14 & -3.85 & 2.82 \\
\hline CSX-1 & 0.00 & 2.38 & 2.39 & 37.30 & 54.70 & 7.60 & 0.40 & 8.00 & 0.18 & 2.71 & -0.08 & 0.05 & 2.68 \\
\hline CXS-2 & 0.00 & 2.53 & 2.39 & 41.50 & 47.70 & 10.04 & 0.76 & 10.80 & 0.10 & 2.92 & -0.41 & -0.07 & 2.87 \\
\hline CXS-3 & 0.00 & 2.44 & 2.39 & 0.00 & 0.00 & 0.00 & 0.00 & 0.00 & 0.00 & 0.00 & 0.00 & 0.00 & 0.00 \\
\hline mean & 0.00 & 2.44 & 2.39 & 40.69 & 29.11 & 4.88 & 0.32 & 5.21 & -0.84 & 2.13 & -1.16 & -0.97 & 2.09 \\
\hline stan dev & 0.00 & 0.06 & 0.00 & 34.35 & 26.30 & 4.72 & 0.33 & 5.04 & 1.87 & 1.42 & 2.00 & 1.92 & 1.40 \\
\hline Sample & fwsk & fwku & inmd & inmn & inso & insk1 & insk2 & inku & trmd & trmn & trso & trsk & trku \\
\hline \multicolumn{14}{|c|}{ Old mountain clastics- Continued } \\
\hline DXS-15 & 0.23 & 1.23 & -4.14 & -3.71 & 2.72 & 0.16 & 0.54 & 0.77 & 17.65 & 26.72 & 3.03 & 0.81 & 0.17 \\
\hline CSX-1 & 0.14 & 0.82 & -0.08 & 0.12 & 2.79 & 0.07 & 0.31 & 0.52 & 1.06 & 2.28 & 4.37 & 0.88 & 0.26 \\
\hline CXS-2 & 0.24 & 0.88 & -0.41 & 0.10 & 2.92 & 0.17 & 0.49 & 0.59 & 1.32 & 2.47 & 4.46 & 0.63 & 0.27 \\
\hline CXS-3 & 0.00 & 0.00 & 0.00 & 0.00 & 0.00 & 0.00 & 0.00 & 0.00 & 0.00 & 0.00 & 0.00 & 0.00 & 0.00 \\
\hline mean & 0.15 & 0.73 & -1.16 & -0.87 & 2.11 & 0.10 & 0.34 & 0.47 & 5.01 & 7.87 & 2.96 & 0.58 & 0.17 \\
\hline stan dev & 0.11 & 0.52 & 2.00 & 1.89 & 1.41 & 0.08 & 0.24 & 0.33 & 8.45 & 12.62 & 2.08 & 0.40 & 0.13 \\
\hline
\end{tabular}

\section{GRAIN-SIZE ANALYSIS}

\section{METHODS}

The wide range in particle size in the debris-avalanche deposit required more than just standard sieve and pipette analyses to properly characterize the deposit. Because the large clasts (fig. 52) are rare compared to the smaller sizes, they are not represented in sufficient quantity in the 2- to 4-kg size sample taken for the sieve and pipette analyses. Therefore, the size distribution of coarse clasts was approximated by tracing areas of coarse clasts on photographic prints of the $1-\mathrm{m}^{2}$ windows. The sample for standard sieve and pipette analysis was taken from a cylindrical hole dug in a cleared flat area adjacent to each window.

The largest clast used in the sieve grain-size analyses was $-5 \phi$ ( $32 \mathrm{~mm}$ diameter) because the sample size is not big enough to accurately represent the distribution of larger clasts. The mass of a spherical $32 \mathrm{~mm}$ clast is 39.5 $\mathrm{g}$; it was calculated using the mean laboratory-measured density of clasts in the debris avalanche, $2.3 \mathrm{~g} / \mathrm{cm}^{3}$. The addition or removal of one $32 \mathrm{~mm}$ clast would change each bar in the histograms of the grain-size distribution of the 2- to $4-\mathrm{kg}$ samples by $<2$ percent. The addition or removal of one clast in the $-5 \phi$ to $-6 \phi$ (32 to $64 \mathrm{~mm}$ diameter) size range would change the distribution by as much as $315.7 \mathrm{~g}$, as much as 16 percent of the sample.

Analyses of the size distribution of coarse clasts (larger than $-5 \phi$ ) from photographic prints rely on an areavolume, or Delasse, relation. The Delasse relation was developed for petrographic thin sections by Chayes (1956). The Delasse relation indicates that "the ratio of the area occupied by.... [mineral or element] A to the area occupied by .... the total measurement area .... is a consistent estimate of the volume percentage of....A in the rock [or exposure] (Chayes, 1956, p. 13)."

In order to apply the thin section analogy, the windows were made as flat as possible with a shovel and a flat trowel. However, it was not possible to slice through clasts, and some clasts fell from the window before the photograph was taken.

The outlines of clasts and of depressions that held clasts were traced on mylar overlays of 8-by-12-inch photographic prints of the windows (fig. 50). A stereo pair of photographs of the windows was examined to help identify the clasts and depressions. The areas of the clasts and 

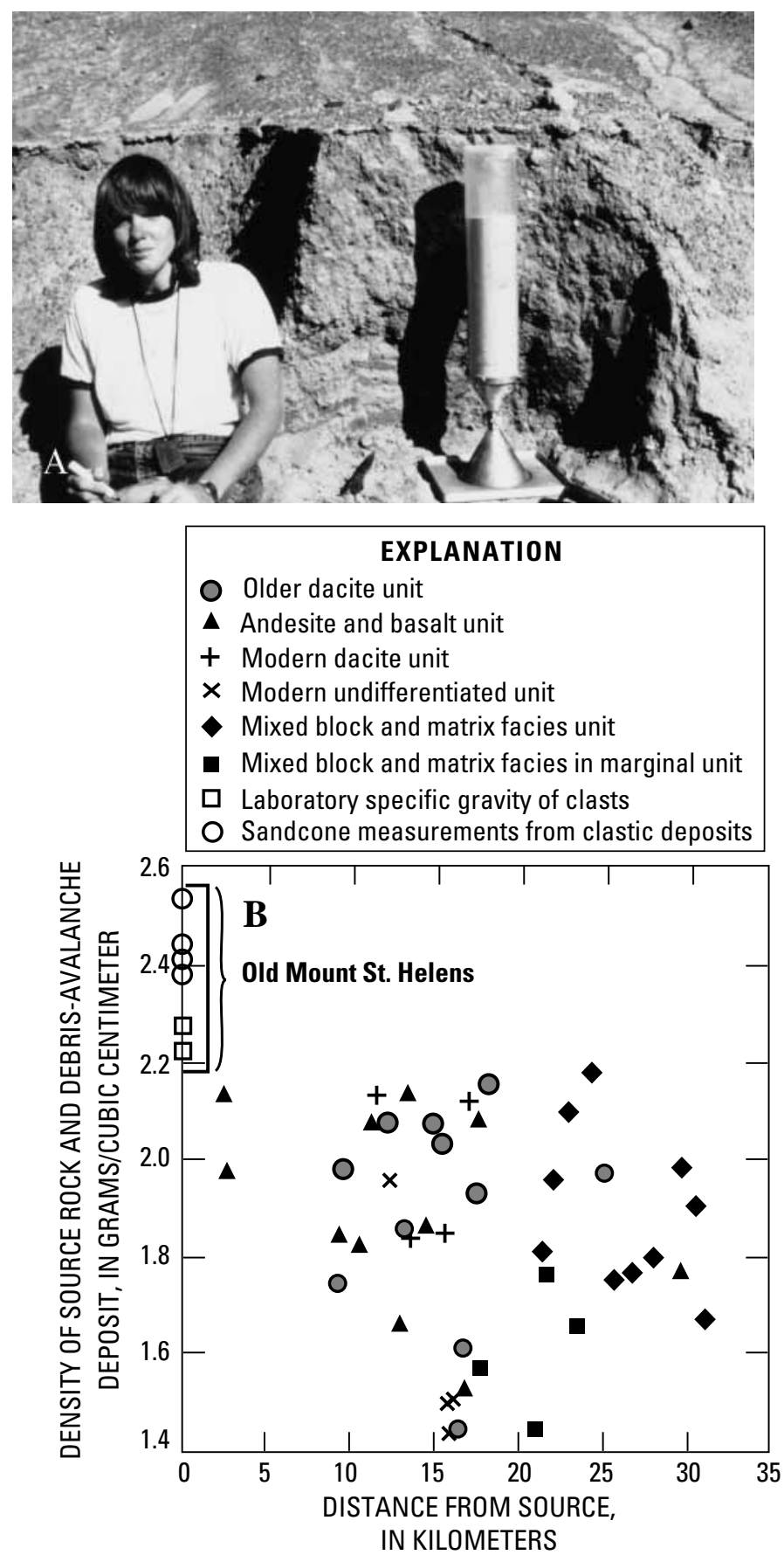

Figure 51. A, Sand cone used to measure field density of deposit. Horizontal shelf is dug in exposure and plate is laid flush on shelf. Cylindrical hole in deposit is dug through hole in plate, material from hole is saved for drying, weighing, and grain-size analysis, and volume of hole is measured by measuring volume of sand dispensed from plastic cylinder. B, Density of source rocks and debris-avalanche deposit versus distance from source $(0-\mathrm{km}$ values are old mountain densities).

depressions were measured with an electronic digitizing table.

The Delasse relation indicates that relative percentages of measured areas are equivalent to relative percent-

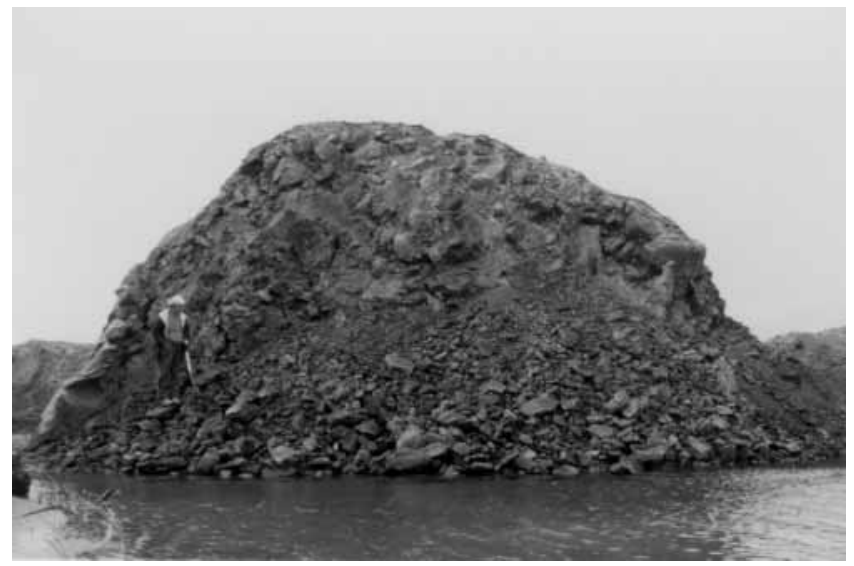

Figure 52. Largest clast found in debris-avalanche deposit, located adjacent to sample locality DXS-26. Clast is jointed but not shattered. Exposed dimensions of clast: $15 \mathrm{~m}$ long by $8 \mathrm{~m}$ wide by 6.2 m high.

ages of volumes for a unit without significant imbrication of ellipsoidal particles (Chayes, 1956). Although imbrication of rubble schlieren is common in the debris-avalanche deposit, imbrication of clasts is extremely rare.

Sieve and pipette analyses are computed as weight percentages, not volume percentages. In order to integrate the data sets, the volume percentages of the coarse material were converted to weight percentages using the relation

$$
W_{c}=\frac{100 \rho_{c} V_{c}}{\rho_{c} V_{c t}+\rho_{f}\left(100-V_{c t}\right)}
$$

where

$\mathrm{W}_{c}=$ weight percent of size class coarser than $-5 \phi$

$\mathrm{V}_{c}=$ volume percent of size class coarser than $-5 \phi$

$\mathrm{V}_{c t}=$ total volume percent of all size classes coarser than-5 $\phi$

$\rho_{c}=$ density of material coarser than $-5 \phi$

$\rho_{f}=$ density of material finer than $-5 \phi$.

The mean density of the material coarser than $-5 \phi$ was measured in the laboratory for each lithologic unit (table 4). The density of the material finer than $-5 \phi$ in the photographs includes the void space in the deposit. It is equivalent to the dry bulk density of the deposit, which was measured for each window (table 4). After conversion to weight percentages, the data for the coarse clasts were integrated with the data from the sieve and pipette analyses to produce table 5 . 
Table 5. Grain-size data in phi $(\phi)$ units for debris-avalanche and blast deposits

[Samples located on plate 4. Results in percent. Material coarser than $-5 \phi$ analyzed by computation of areas of clasts on $1-\mathrm{m}^{2}$ windows (see text); material finer than $-5 \phi$ analyzed by standard sieve and pipette techniques. "without coarse fraction" indicates that data include only sieved and pipetted fraction (material finer than -5申). Sprt, at Spirit Lake; Cold, at Coldwater Lake; Cstl, at Castle Lake; stan dev, standard deviation]

\begin{tabular}{|c|c|c|c|c|c|c|c|c|c|c|c|c|c|c|c|c|c|c|c|}
\hline Sample & -8 & -7 & -6 & -5 & -4 & -3 & -2 & -1 & 0 & 1 & 2 & 3 & 4 & 5 & 6 & 7 & 8 & 9 & 14 \\
\hline \multicolumn{20}{|c|}{ Older dacite unit } \\
\hline$\overline{\mathrm{DXS}-2}$ & 0.00 & 6.14 & 7.32 & 6.01 & 10.24 & 13.03 & 9.22 & 7.11 & 7.19 & 6.77 & 6.85 & 6.09 & 5.75 & 2.98 & 2.24 & 1.82 & 0.50 & 0.00 & 0.75 \\
\hline DXS-4 & 0.00 & 0.00 & 2.01 & 1.80 & 10.23 & 9.32 & 7.29 & 6.58 & 9.42 & 8.40 & 13.27 & 11.95 & 8.40 & 3.86 & 2.72 & 2.27 & 1.47 & 0.11 & 0.91 \\
\hline DXS-6 & 0.00 & 1.53 & 3.86 & 2.14 & 1.39 & 10.45 & 16.83 & 16.46 & 13.78 & 11.93 & 9.43 & 5.83 & 2.77 & 1.66 & 0.97 & 0.51 & 0.07 & 0.04 & 0.36 \\
\hline DXS-20 & 0.00 & 0.00 & 0.00 & 1.74 & 0.69 & 3.44 & 5.80 & 10.32 & 14.35 & 13.66 & 12.87 & 10.71 & 9.04 & 5.74 & 4.70 & 3.65 & 0.70 & 0.35 & 2.26 \\
\hline DXS-21 & 0.00 & 3.83 & 3.62 & 3.38 & 8.74 & 7.04 & 6.60 & 7.31 & 9.10 & 9.81 & 10.34 & 9.54 & 8.74 & 4.06 & 2.99 & 2.39 & 1.19 & 0.12 & 1.19 \\
\hline DXS-22 & 0.00 & 3.05 & 5.59 & 6.84 & 5.66 & 12.00 & 8.88 & 6.59 & 7.95 & 7.61 & 8.37 & 7.61 & 7.52 & 4.69 & 3.09 & 2.22 & 1.23 & 0.12 & 0.99 \\
\hline DXS-24 & 0.00 & 0.00 & 0.00 & 0.14 & 0.20 & 3.00 & 10.28 & 9.19 & 11.08 & 19.87 & 15.08 & 11.48 & 7.89 & 4.48 & 3.30 & 1.88 & 0.47 & 0.12 & 1.53 \\
\hline $825-3$ (Sprt) & 0.00 & 2.84 & 2.86 & 3.07 & 0.00 & 3.28 & 6.84 & 4.93 & 6.66 & 9.40 & 12.77 & 12.86 & 13.32 & 4.87 & 6.56 & 5.08 & 1.27 & 0.21 & 3.17 \\
\hline $827-3$ (Sprt) & 0.00 & 0.00 & 0.00 & 0.00 & 3.60 & 6.90 & 6.40 & 7.10 & 13.10 & 13.40 & 12.30 & 11.10 & 10.60 & 5.27 & 4.96 & 3.26 & 0.16 & 0.16 & 1.71 \\
\hline MS-10(Cold) & 0.00 & 0.00 & 0.00 & 0.00 & 4.00 & 8.50 & 8.50 & 9.40 & 10.60 & 11.30 & 13.20 & 12.10 & 8.60 & 5.11 & 3.73 & 3.04 & 0.41 & 0.28 & 1.24 \\
\hline 826-3(Cstl) & 0.00 & 0.00 & 0.00 & 0.00 & 9.28 & 10.34 & 8.96 & 9.38 & 9.49 & 10.98 & 12.37 & 10.98 & 8.42 & 3.63 & 2.84 & 2.06 & 0.39 & 0.10 & 0.79 \\
\hline mean & 0.00 & 1.58 & 2.30 & 2.28 & 4.91 & 7.94 & 8.96 & 8.58 & 10.25 & 11.19 & 11.53 & 10.02 & 8.28 & 4.21 & 3.46 & 2.56 & 0.71 & 0.15 & 1.35 \\
\hline stan dev & 0.00 & 2.11 & 2.59 & 2.39 & 4.12 & 3.53 & 3.04 & 3.07 & 2.61 & 3.64 & 2.47 & 2.45 & 2.63 & 1.16 & 1.50 & 1.18 & 0.49 & 0.10 & 0.79 \\
\hline \multicolumn{20}{|c|}{ Andesite and basalt unit } \\
\hline DXS-11 & 0.00 & 1.89 & 1.08 & 1.09 & 15.90 & 11.62 & 8.77 & 8.99 & 13.27 & 13.16 & 9.32 & 6.14 & 4.17 & 2.49 & 1.29 & 0.51 & 0.09 & 0.09 & 0.14 \\
\hline DXS-13 & 0.00 & 0.00 & 3.65 & 4.21 & 9.03 & 8.27 & 9.79 & 6.28 & 10.94 & 13.03 & 14.17 & 9.03 & 5.33 & 2.39 & 1.69 & 1.38 & 0.06 & 0.13 & 0.63 \\
\hline DXS-14 & 0.00 & 0.00 & 0.64 & 2.16 & 9.48 & 12.27 & 12.27 & 11.23 & 11.13 & 11.23 & 11.03 & 7.73 & 4.53 & 2.52 & 1.82 & 1.32 & 0.06 & 0.06 & 0.50 \\
\hline DXS-16 & 0.00 & 1.63 & 4.48 & 4.58 & 15.70 & 12.56 & 9.00 & 8.90 & 7.96 & 7.01 & 6.81 & 6.49 & 6.07 & 4.05 & 2.37 & 1.23 & 0.35 & 0.18 & 0.62 \\
\hline DXS-23 & 0.00 & 0.00 & 1.65 & 8.33 & 6.60 & 9.67 & 10.97 & 13.58 & 11.81 & 9.11 & 9.86 & 7.63 & 5.12 & 3.06 & 1.48 & 0.68 & 0.17 & 0.00 & 0.28 \\
\hline DXS-25 & 0.00 & 6.49 & 6.94 & 5.76 & 14.62 & 11.38 & 11.03 & 8.93 & 8.58 & 8.14 & 6.57 & 3.85 & 2.98 & 1.80 & 1.23 & 1.09 & 0.10 & 0.00 & 0.52 \\
\hline DXS-27 & 0.00 & 1.53 & 2.34 & 4.37 & 2.39 & 4.49 & 6.12 & 6.59 & 9.84 & 11.28 & 13.86 & 13.29 & 10.90 & 5.07 & 3.25 & 2.47 & 0.26 & 0.13 & 1.82 \\
\hline DXS-38 & 0.00 & 5.73 & 1.18 & 3.32 & 9.29 & 9.00 & 7.33 & 11.93 & 14.96 & 10.07 & 8.31 & 6.85 & 5.28 & 2.97 & 1.89 & 1.01 & 0.14 & 0.07 & 0.68 \\
\hline $825-5$ (Sprt) & 0.00 & 4.37 & 2.33 & 7.66 & 19.19 & 16.44 & 10.96 & 8.14 & 7.11 & 7.19 & 7.02 & 5.14 & 2.83 & 1.04 & 0.33 & 0.08 & 0.03 & 0.02 & 0.13 \\
\hline $827-2$ (Sprt) & 0.00 & 8.33 & 12.71 & 1.29 & 20.34 & 11.18 & 6.78 & 5.99 & 6.61 & 7.05 & 6.69 & 4.76 & 3.61 & 1.87 & 1.35 & 0.84 & 0.09 & 0.00 & 0.51 \\
\hline MS-9 (Cold) & 0.00 & 7.24 & 5.03 & 3.20 & 8.45 & 10.54 & 7.09 & 6.36 & 7.18 & 8.91 & 10.63 & 8.00 & 6.36 & 3.96 & 2.86 & 2.53 & 0.22 & 0.22 & 1.21 \\
\hline mean & 0.00 & 3.38 & 3.82 & 4.18 & 11.91 & 10.67 & 9.10 & 8.81 & 9.94 & 9.65 & 9.48 & 7.17 & 5.20 & 2.84 & 1.78 & 1.19 & 0.14 & 0.08 & 0.64 \\
\hline stan dev & 0.00 & 3.14 & 3.53 & 2.36 & 5.60 & 2.98 & 2.07 & 2.53 & 2.73 & 2.28 & 2.75 & 2.54 & 2.22 & 1.16 & 0.81 & 0.75 & 0.10 & 0.08 & 0.49 \\
\hline \multicolumn{20}{|c|}{ Modern dacite unit } \\
\hline$\overline{\mathrm{DXS}-3}$ & 7.64 & 2.96 & 6.92 & 8.74 & 11.03 & 10.16 & 7.88 & 5.67 & 5.91 & 7.17 & 8.35 & 5.75 & 4.41 & 2.52 & 2.07 & 1.48 & 0.30 & 0.07 & 0.96 \\
\hline DXS-12 & 0.00 & 38.73 & 21.42 & 16.91 & 3.82 & 4.98 & 3.84 & 2.65 & 2.19 & 1.58 & 1.21 & 0.91 & 0.67 & 0.42 & 0.31 & 0.22 & 0.07 & 0.01 & 0.08 \\
\hline DXS-19 & 0.00 & 0.00 & 1.03 & 4.01 & 14.30 & 15.46 & 10.81 & 8.02 & 6.28 & 5.58 & 8.48 & 11.04 & 6.74 & 3.30 & 2.06 & 1.73 & 0.41 & 0.08 & 0.66 \\
\hline MS-1(Cold) & 0.00 & 1.79 & 2.51 & 3.95 & 9.57 & 13.10 & 8.89 & 8.20 & 8.20 & 8.89 & 9.35 & 7.98 & 6.72 & 3.46 & 2.82 & 2.38 & 0.54 & 0.11 & 1.52 \\
\hline mean & 1.91 & 10.87 & 7.97 & 8.40 & 9.68 & 10.93 & 7.86 & 6.14 & 5.64 & 5.81 & 6.85 & 6.42 & 4.63 & 2.42 & 1.81 & 1.45 & 0.33 & 0.07 & 0.81 \\
\hline stan dev & 3.82 & 18.61 & 9.31 & 6.10 & 4.38 & 4.52 & 2.94 & 2.59 & 2.51 & 3.12 & 3.78 & 4.27 & 2.86 & 1.40 & 1.06 & 0.91 & 0.20 & 0.04 & 0.60 \\
\hline \multicolumn{20}{|c|}{ Modern undifferentiated unit } \\
\hline$\overline{\mathrm{DXS}-17}$ & 0.00 & 0.00 & 2.82 & 4.24 & 13.60 & 15.76 & 10.82 & 8.24 & 5.77 & 4.74 & 6.18 & 7.11 & 7.42 & 6.25 & 3.59 & 2.39 & 0.27 & 0.13 & 0.66 \\
\hline $826-2(\mathrm{Cstl})$ & 0.00 & 0.00 & 3.55 & 2.06 & 11.03 & 8.90 & 9.03 & 8.90 & 10.28 & 10.15 & 10.03 & 8.77 & 7.52 & 4.11 & 3.03 & 1.27 & 0.39 & 0.20 & 0.78 \\
\hline $827-6($ Cstl $)$ & 9.43 & 0.00 & 2.31 & 0.81 & 8.62 & 10.88 & 8.31 & 6.36 & 6.67 & 8.83 & 10.47 & 9.75 & 8.01 & 3.91 & 3.15 & 1.15 & 0.38 & 0.10 & 0.86 \\
\hline 827-7(Cstl) & 0.00 & 0.00 & 5.18 & 1.13 & 12.84 & 11.56 & 8.62 & 6.57 & 6.66 & 8.13 & 9.70 & 9.21 & 7.84 & 3.39 & 4.39 & 3.01 & 0.38 & 0.25 & 1.13 \\
\hline mean & 2.36 & 0.00 & 3.46 & 2.06 & 11.52 & 11.78 & 9.19 & 7.52 & 7.34 & 7.96 & 9.10 & 8.71 & 7.70 & 4.41 & 3.54 & 1.96 & 0.35 & 0.17 & 0.86 \\
\hline stan dev & 4.72 & 0.00 & 1.25 & 1.55 & 2.22 & 2.89 & 1.12 & 1.25 & 2.00 & 2.31 & 1.97 & 1.14 & 0.27 & 1.26 & 0.62 & 0.90 & 0.06 & 0.07 & 0.20 \\
\hline
\end{tabular}


Table 5. Grain-size data in phi $(\phi)$ units for debris-avalanche and blast deposits--Continued

\begin{tabular}{|c|c|c|c|c|c|c|c|c|c|c|c|c|c|c|c|c|c|c|c|}
\hline Sample & -8 & -7 & -6 & -5 & -4 & -3 & -2 & -1 & 0 & 1 & 2 & 3 & 4 & 5 & 6 & 7 & 8 & 9 & 14 \\
\hline \multicolumn{20}{|c|}{ Mixed block and matrix facies unit } \\
\hline$\overline{\mathrm{DXS}-1}$ & 0.00 & 4.22 & 2.05 & 1.33 & 10.53 & 9.98 & 7.48 & 7.30 & 7.48 & 7.58 & 9.98 & 9.98 & 8.50 & 3.94 & 4.35 & 3.12 & 0.95 & 0.14 & 1.09 \\
\hline DXS-8 & 0.00 & 0.00 & 1.22 & 2.37 & 9.73 & 9.40 & 9.51 & 9.30 & 9.62 & 10.16 & 11.67 & 12.43 & 7.35 & 2.97 & 1.88 & 1.52 & 0.14 & 0.07 & 0.65 \\
\hline DXS-29 & 0.00 & 4.55 & 3.79 & 1.85 & 13.57 & 9.72 & 7.99 & 6.45 & 7.60 & 10.01 & 10.97 & 7.99 & 6.26 & 3.14 & 2.40 & 2.03 & 0.09 & 0.18 & 1.39 \\
\hline DXS-30 & 0.00 & 1.42 & 3.87 & 0.57 & 7.44 & 12.24 & 8.94 & 6.78 & 9.04 & 12.71 & 11.20 & 8.66 & 6.50 & 3.83 & 2.87 & 2.45 & 0.11 & 0.21 & 1.17 \\
\hline DXS-31 & 0.00 & 0.00 & 1.19 & 2.87 & 7.10 & 7.39 & 8.06 & 9.11 & 9.69 & 11.23 & 14.58 & 11.90 & 7.58 & 3.72 & 2.33 & 1.86 & 0.19 & 0.09 & 1.12 \\
\hline DXS-33 & 0.00 & 4.68 & 3.93 & 4.20 & 6.53 & 9.84 & 8.38 & 8.77 & 9.25 & 9.94 & 10.62 & 9.64 & 5.84 & 3.10 & 2.26 & 1.59 & 0.67 & 0.00 & 0.75 \\
\hline DXS-34 & 0.00 & 0.00 & 1.60 & 2.19 & 10.10 & 7.91 & 8.79 & 6.37 & 9.88 & 12.63 & 12.08 & 9.66 & 6.81 & 4.31 & 2.87 & 2.39 & 0.84 & 0.00 & 1.56 \\
\hline DXS-35 & 0.00 & 4.49 & 2.28 & 3.94 & 13.40 & 11.47 & 8.29 & 7.16 & 7.38 & 8.06 & 10.00 & 10.00 & 6.13 & 2.95 & 1.70 & 1.40 & 0.59 & 0.00 & 0.74 \\
\hline DXS-36 & 0.00 & 0.00 & 4.31 & 3.92 & 7.73 & 7.92 & 6.80 & 8.39 & 10.16 & 10.34 & 12.02 & 12.67 & 8.57 & 3.30 & 1.79 & 1.22 & 0.22 & 0.07 & 0.57 \\
\hline DXS-37 & 0.00 & 0.00 & 3.04 & 1.62 & 8.73 & 7.21 & 7.01 & 7.72 & 10.76 & 11.88 & 12.29 & 9.54 & 7.41 & 4.09 & 3.20 & 3.07 & 0.26 & 0.26 & 1.92 \\
\hline mean & 0.00 & 1.94 & 2.73 & 2.49 & 9.49 & 9.31 & 8.13 & 7.74 & 9.09 & 10.45 & 11.54 & 10.25 & 7.09 & 3.54 & 2.57 & 2.07 & 0.41 & 0.10 & 1.10 \\
\hline stan dev & 0.00 & 2.24 & 1.20 & 1.23 & 2.49 & 1.70 & 0.85 & 1.09 & 1.20 & 1.73 & 1.35 & 1.58 & 0.95 & 0.50 & 0.80 & 0.67 & 0.32 & 0.09 & 0.44 \\
\hline \multicolumn{20}{|c|}{ Marginal mixed block and matrix facies unit } \\
\hline$\overline{\text { DXS-9 }}$ & 0.00 & 6.56 & 4.36 & 3.40 & 9.36 & 8.58 & 6.92 & 6.92 & 7.21 & 8.38 & 12.57 & 9.36 & 6.82 & 3.63 & 2.48 & 2.20 & 0.29 & 0.10 & 0.86 \\
\hline DXS-26 & 0.00 & 0.00 & 1.34 & 4.71 & 11.68 & 8.93 & 7.76 & 6.28 & 8.64 & 11.29 & 11.98 & 9.33 & 7.17 & 4.14 & 2.94 & 2.07 & 0.87 & 0.11 & 0.76 \\
\hline DXS-28 & 0.00 & 0.00 & 2.34 & 3.60 & 13.07 & 11.85 & 11.76 & 5.08 & 6.87 & 8.28 & 10.82 & 8.37 & 6.77 & 4.03 & 3.25 & 2.35 & 0.56 & 0.00 & 1.01 \\
\hline DXS-32 & 0.00 & 5.97 & 3.04 & 1.92 & 3.34 & 6.32 & 6.50 & 7.15 & 8.17 & 9.29 & 12.63 & 12.45 & 9.01 & 5.54 & 3.98 & 2.56 & 0.43 & 0.14 & 1.56 \\
\hline mean & 0.00 & 3.13 & 2.77 & 3.41 & 9.36 & 8.92 & 8.24 & 6.36 & 7.72 & 9.31 & 12.00 & 9.88 & 7.44 & 4.34 & 3.16 & 2.30 & 0.54 & 0.09 & 1.05 \\
\hline stan dev & 0.00 & 3.63 & 1.27 & 1.15 & 4.30 & 2.27 & 2.41 & 0.93 & 0.82 & 1.40 & 0.84 & 1.78 & 1.06 & 0.83 & 0.63 & 0.21 & 0.25 & 0.06 & 0.36 \\
\hline \multicolumn{20}{|c|}{ All debris avalanche samples } \\
\hline mean & 0.39 & 2.95 & 3.44 & 3.44 & 9.14 & 9.64 & 8.59 & 7.92 & 9.00 & 9.69 & 10.42 & 8.90 & 6.78 & 3.58 & 2.67 & 1.93 & 0.42 & 0.11 & 0.99 \\
\hline stan dev & 1.81 & 6.07 & 3.67 & 2.99 & 4.76 & 3.10 & 2.15 & 2.33 & 2.54 & 2.92 & 2.70 & 2.68 & 2.32 & 1.21 & 1.21 & 0.97 & 0.36 & 0.09 & 0.59 \\
\hline \multicolumn{20}{|c|}{ All debris avalanche samples without coarse fraction } \\
\hline mean & 0.00 & 0.00 & 0.00 & 0.00 & 10.46 & 11.04 & 9.72 & 8.87 & 9.97 & 10.66 & 11.44 & 9.75 & 7.44 & 3.94 & 2.93 & 2.11 & 0.46 & 0.12 & 1.09 \\
\hline stan dev & 0.00 & 0.00 & 0.00 & 0.00 & 5.61 & 3.92 & 2.48 & 2.34 & 2.26 & 2.51 & 2.37 & 2.49 & 2.28 & 1.18 & 1.23 & 1.00 & 0.39 & 0.09 & 0.62 \\
\hline \multicolumn{20}{|c|}{ Blast deposit above debris avalanche } \\
\hline$\overline{D X S-5}$ & 0.00 & 0.00 & 1.09 & 1.42 & 4.49 & 7.12 & 9.07 & 9.56 & 9.46 & 9.56 & 10.92 & 15.11 & 9.65 & 4.40 & 3.27 & 3.02 & 0.50 & 0.00 & 1.38 \\
\hline DXS-18 & 0.00 & 0.00 & 2.34 & 4.86 & 10.96 & 9.47 & 7.97 & 6.48 & 7.87 & 9.07 & 11.36 & 13.36 & 7.28 & 3.59 & 1.97 & 1.88 & 0.45 & 0.09 & 0.99 \\
\hline 826-4(Cstl) & 0.00 & 0.00 & 3.22 & 0.83 & 3.11 & 9.22 & 8.29 & 6.01 & 7.88 & 8.81 & 12.44 & 12.85 & 10.78 & 4.64 & 4.64 & 3.98 & 0.83 & 0.17 & 2.32 \\
\hline mean & 0.00 & 0.00 & 2.22 & 2.37 & 6.19 & 8.60 & 8.44 & 7.35 & 8.40 & 9.15 & 11.57 & 13.77 & 9.24 & 4.21 & 3.29 & 2.96 & 0.59 & 0.09 & 1.56 \\
\hline stan dev & 0.00 & 0.00 & 1.07 & 2.18 & 4.19 & 1.29 & 0.57 & 1.93 & 0.92 & 0.38 & 0.78 & 1.19 & 1.79 & 0.55 & 1.34 & 1.05 & 0.21 & 0.09 & 0.68 \\
\hline \multicolumn{20}{|c|}{ Old mountain clastics (older dacite) } \\
\hline$\overline{\mathrm{DXS}}-15$ & 0.00 & 10.07 & 10.42 & 11.78 & 21.13 & 15.31 & 9.41 & 5.82 & 4.61 & 3.39 & 2.71 & 2.03 & 1.29 & 0.98 & 0.53 & 0.28 & 0.10 & 0.02 & 0.12 \\
\hline CXS-1 & 0.00 & 0.00 & 0.00 & 0.00 & 2.40 & 8.60 & 16.10 & 10.20 & 13.90 & 10.80 & 11.10 & 11.80 & 7.10 & 2.96 & 2.72 & 1.68 & 0.24 & 0.16 & 0.24 \\
\hline CXS-2 & 0.00 & 0.00 & 0.00 & 0.00 & 2.80 & 10.60 & 15.40 & 12.70 & 13.80 & 9.90 & 8.80 & 9.80 & 5.40 & 3.56 & 3.24 & 3.02 & 0.22 & 0.32 & 0.43 \\
\hline mean & 0.00 & 3.36 & 3.47 & 3.93 & 8.78 & 11.50 & 13.64 & 9.57 & 10.77 & 8.03 & 7.54 & 7.88 & 4.60 & 2.50 & 2.16 & 1.66 & 0.19 & 0.17 & 0.26 \\
\hline stan dev & 0.00 & 5.81 & 6.02 & 6.80 & 10.70 & 3.45 & 3.68 & 3.48 & 5.33 & 4.04 & 4.34 & 5.16 & 2.99 & 1.35 & 1.44 & 1.37 & 0.08 & 0.15 & 0.16 \\
\hline
\end{tabular}




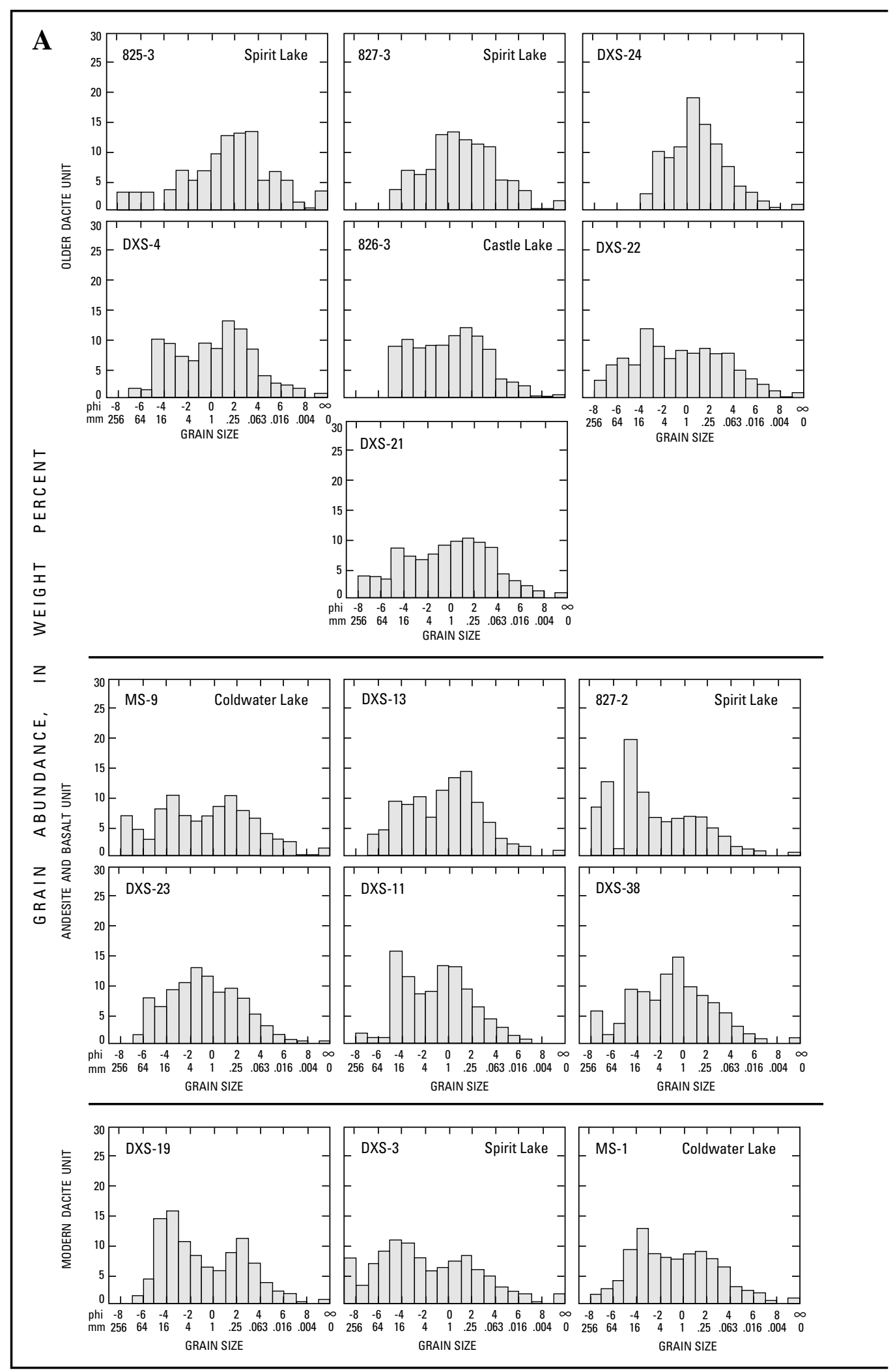

Figure 53. Histograms of samples from the debris-avalanche and blast deposits. Distance from source increases from left to right within each unit type. See plate 4 for location of samples. Bars from size classes larger than $-5 \phi$ not used to classify, because of change in method of analysis at $-5 \phi$. A, Debris avalanche bimodal histograms. B, Debris avalanche Type 1 unimodal histograms with fine-grained peak. C, Debris avalanche Type 2 unimodal histograms with coarse-grained peak. D, Blast-deposit histograms. 


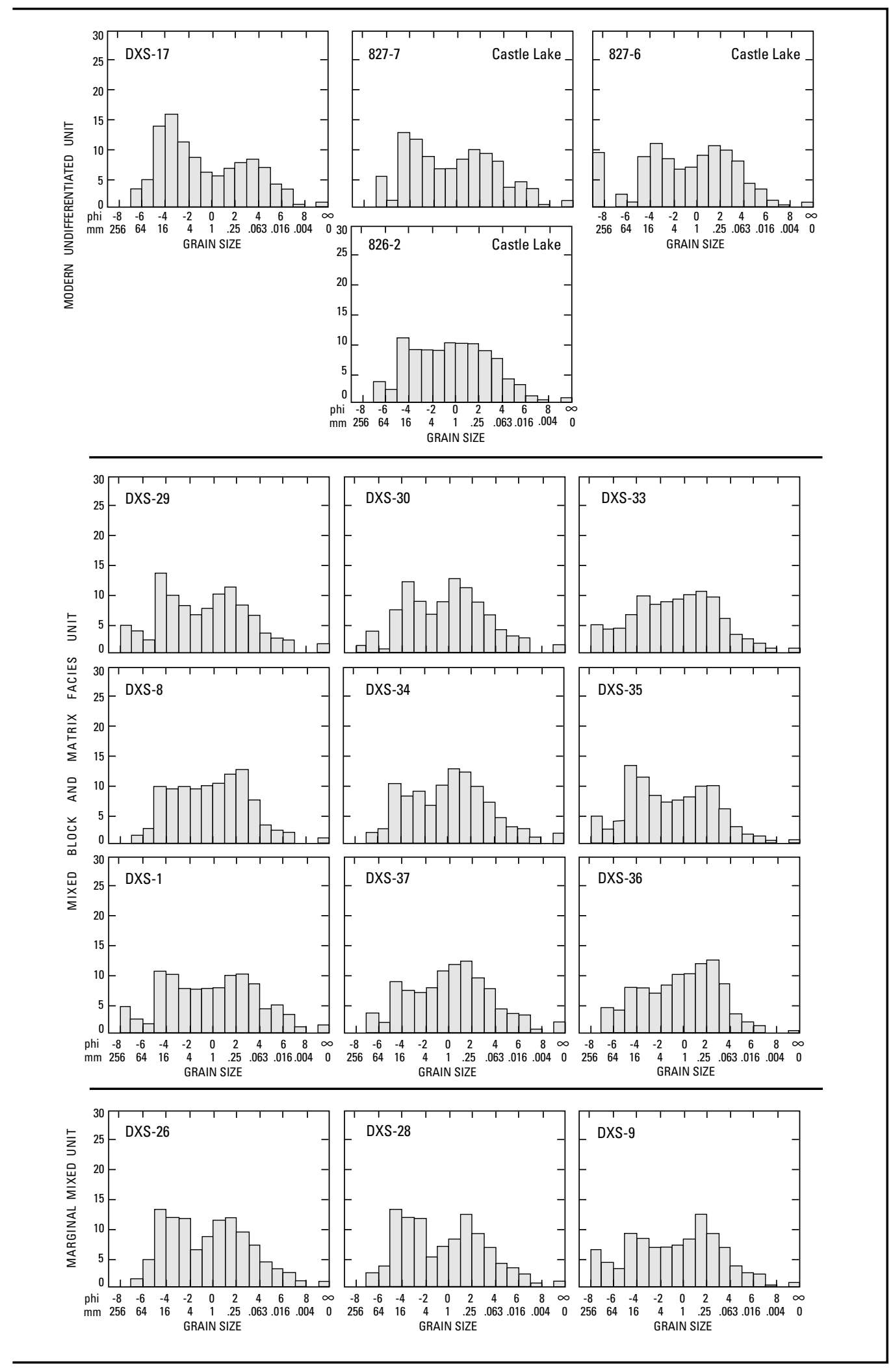

Figure 53. Histograms of samples from the debris-avalanche and blast deposits--Continued. 


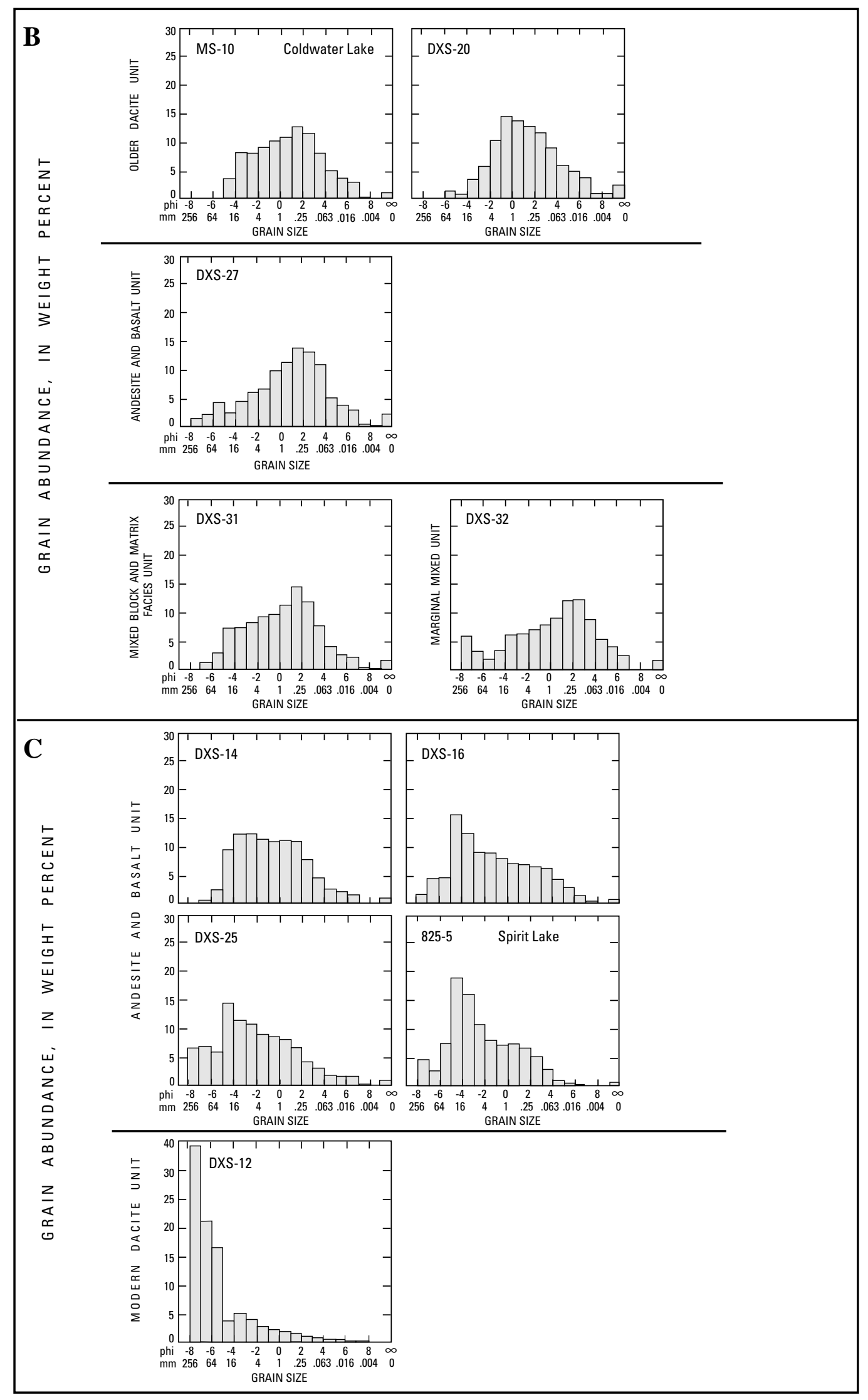

Figure 53. Histograms of samples from the debris-avalanche and blast deposits-Continued. 


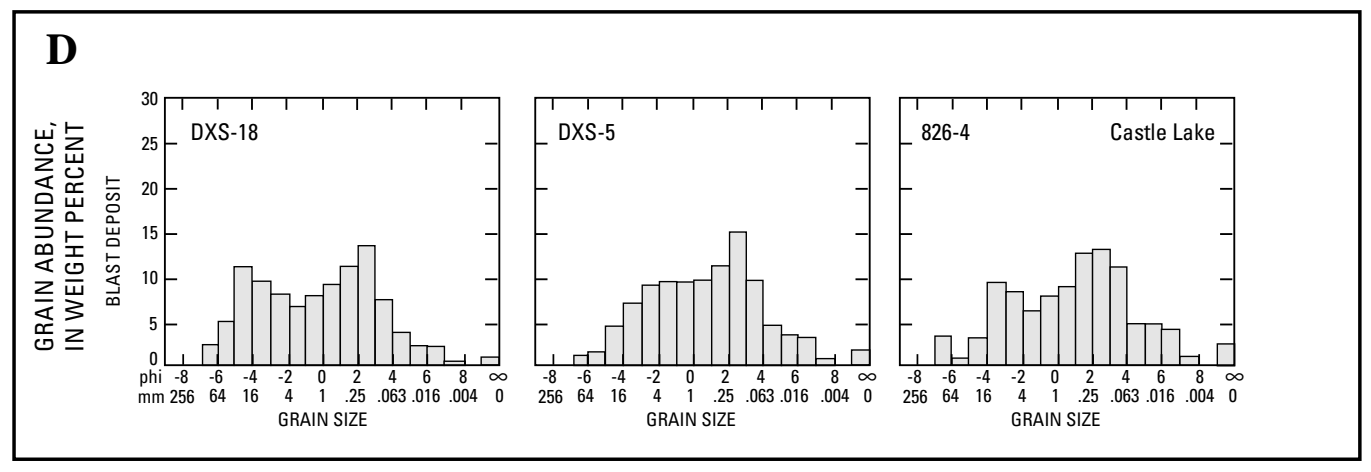

Figure 53. Histograms of samples from the debris-avalanche and blast deposits-Continued.

\section{RESULTS}

\section{GENERAL STATEMENT}

The results of the grain-size analyses were plotted as histograms and as cumulative normal probability plots and cumulative Rosin-law plots. Various standard grainsize statistics were calculated using a computer program, and they were plotted in different ways. In order to make comparisons with statistics used by various geologists and engineers, graphically determined values computed by the methods of Folk and Ward (1957), Inman (1952), and Trask (1930) are included in table 4. The Folk and Ward and Inman values for mean, median, and sorting are intended to approximate values determined by the method of moments (Folk, 1974), in which every grainsize interval affects the results. For the irregular distributions of sizes that are typical of the debris-avalanche samples, moment statistics are much better measures (Folk, 1974) than graphically derived statistics, which are calculated from only a few percentage lines and the grain-sizes are assumed to be approximately normally distributed.

\section{DISTRIBUTION PLOTS}

The grain-size distribution of individual samples was plotted on histograms (fig. 53), on cumulative plots (fig. 54), and on Rosin-law plots (fig. 54). Each type of plot illustrates several features characteristic of the debrisavalanche deposit.

Grain-size distributions are of three general types. Most are bimodal (fig. 53A); the fine-grained peak in the histogram is between $-1 \phi$ and $3 \phi$ (peaks in the larger than $-5 \phi$ categories are ignored because of the inherent inaccuracies of the measurement of the coarse clasts) and the maxima of this peak generally lies between $0 \phi$ and $2 \phi$. Most of the rest are type 1 unimodal samples (fig. 53B) with the same peak and a few are type 2 unimodal samples (fig. 53C) with a coarser peak (maximum value in a size class coarser than $-2 \phi$ ).
The $-1 \phi$ to $3 \phi$ peaks in all of the bimodal histograms and in the first type of unimodal histograms are probably the result of the size of the plagioclase, amphibole, and pyroxene phenocrysts in the source rocks. Many authors have noted the concentration of crystals in this size range in sieved samples of volcaniclastic deposits of intermediate and silicic composition from different parts of the world (for example, Walker and Croasdale, 1971; Kobayashi and others, 1983; Sparks, 1976; Smith and Roobol, 1982). This concentration of crystals produces a peak in the published histograms of these samples because fragments just larger than $-1 \phi$ consist of more than one crystal or a crystal and glass, and they are more easily broken than individual crystals (Davies and others, 1978). Although a rigorous analysis of the crystal size in Mount St. Helens' rocks was not undertaken, a cursory examination of thin sections and hand specimens (figs. 5, 6, and 9) of Mount St. Helens' rocks indicates that this concentration is also present in rocks of the debris avalanche.

The histograms also show graphically the paucity of material in the very fine silt to coarse clay range, $7 \phi$ to $9 \phi$ ( 2 to $8 \mu \mathrm{m}$ ). The lack of material in this size range (averaging 0.42 percent of the sample for $7 \phi$ to $8 \phi$ and 0.11 percent for $8 \phi$ to $9 \phi$, compared to 1.93 percent for $6 \phi$ to $7 \phi$ and 0.99 percent finer than $9 \phi$ ) may be only apparent, since it may result from the compression of all size fractions finer than $9 \phi$ into one bar of the histogram. It is also possible that the lack of the material in the $7 \phi$ to $9 \phi$ range may result from the breakdown of the 2 to $8 \mu \mathrm{m}$ material to less than $2 \mu \mathrm{m}$-size material by hydrothermal alteration, from agglomerations of particles not dispersed by the standard dispersant used in pipetting, or from other inaccuracies in the pipetting technique.

\section{CUMULATIVE PLOTS}

Cumulative probability plots of samples of the debris-avalanche deposit graphically illustrate the conformity of the grain-size distributions to a normal distribution, and cumulative Rosin-law plots of the grain-size 


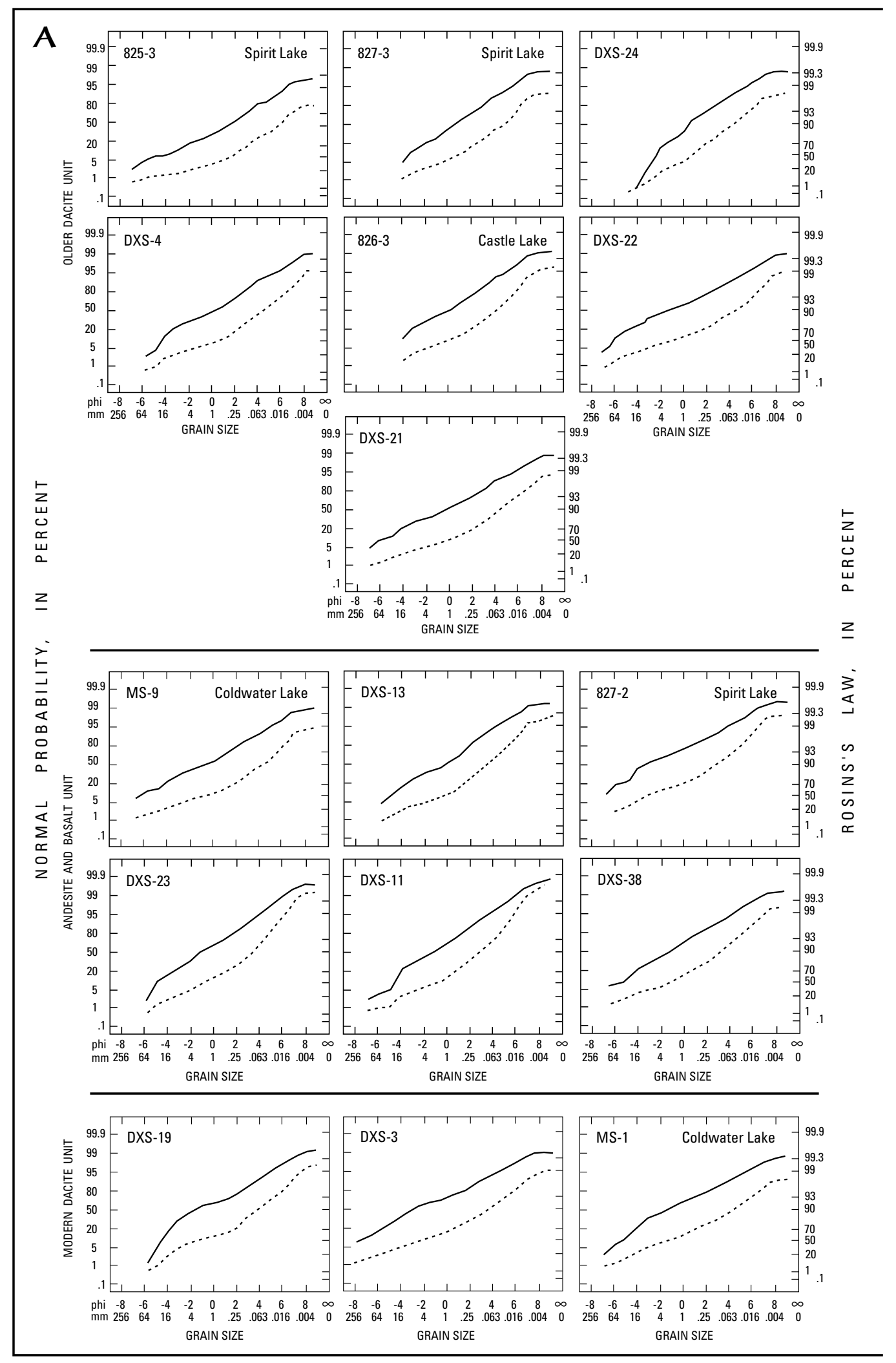

Figure 54. Cumulative probability (solid line) and Rosin-law (dashed line) plots of samples from debrisavalanche and overlying blast deposits. Distance from source increases from left to right within each unit type. See plate 4 for location of samples. Classified as in figure 53. A, Debris avalanche with bimodal histograms. B, Debris avalanche with Type 1 unimodal histograms. C, Debris avalanche with Type 2 unimodal histograms. D, Blast deposit. 


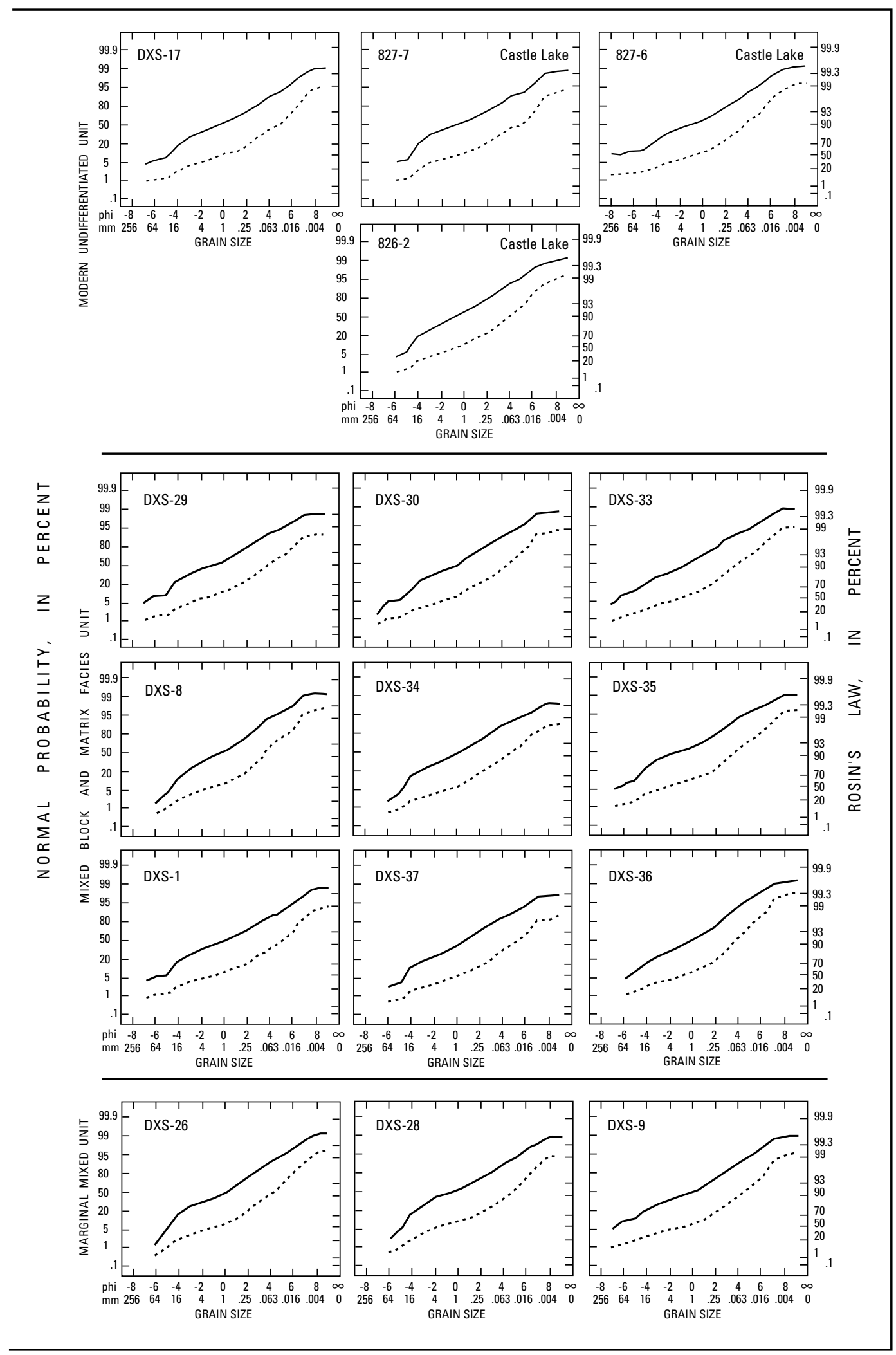

Figure 54. Cumulative probability (solid line) and Rosin-law (dashed line) plots of samples from debris-avalanche and overlying blast deposits--Continued. 


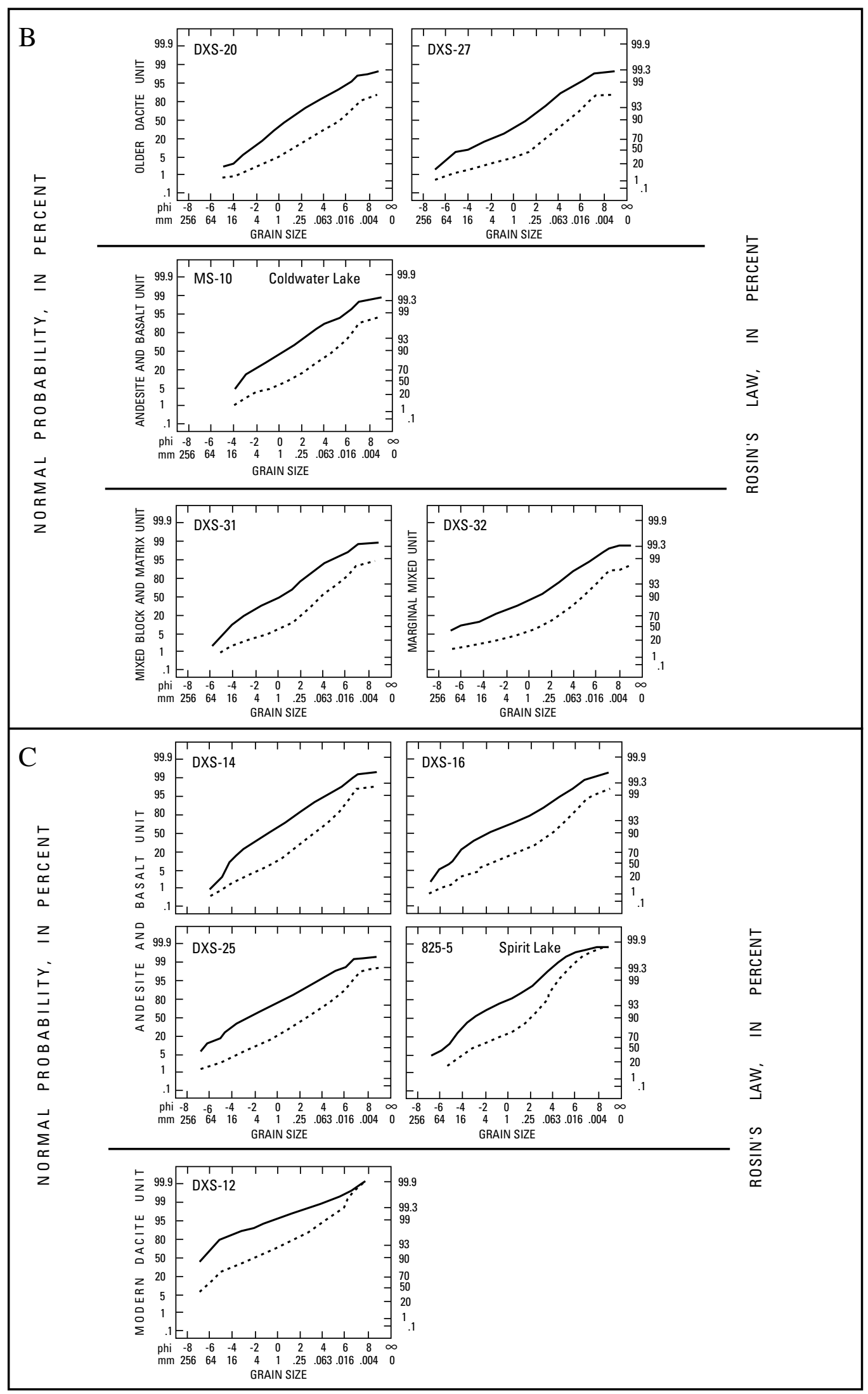

Figure 54. Cumulative probability (solid line) and Rosin-law (dashed line) plots of samples from debris-avalanche and overlying blast deposits--Continued. 


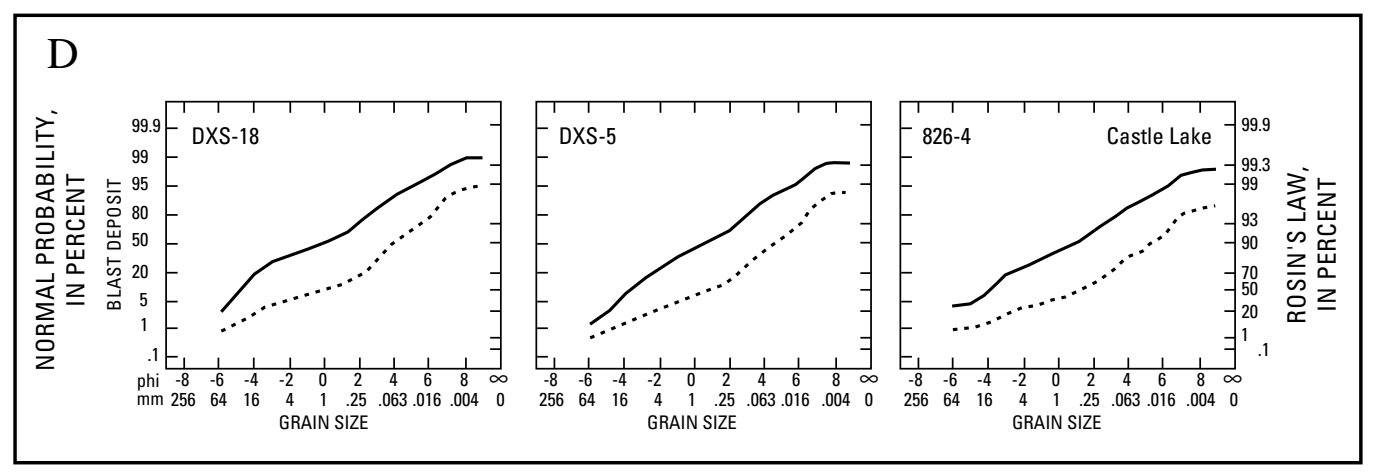

Figure 54. Cumulative probability (solid line) and Rosin-law (dashed line) plots of samples from debris-avalanche and overlying blast deposits-Continued.

distributions of samples test the conformity of the distributions to Rosin's law of crushing. Sediments from one source material that have been sorted by a single sorting mechanism generally plot as the normal distribution (Folk, 1966). Rosin's law is a mathematical function that describes the grain-size distribution of a number of different artificial products such as broken coal and cement, and Kittleman (1964) showed that it also applies to the grain-size distributions of granite scree and broken hydrothermal quartz. A straight line on a cumulative probability plot indicates a normal distribution, but a straight line on a Rosin-law plot indicates that a sample follows the Rosin-law distribution.

There are significant bends in nearly all the plots of both types (fig. 54) that indicate departures from both the normal and Rosin-law distributions. Most of the samples have bends at $-4 \phi$ to $-5 \phi$; these bends indicate the change in method of analysis from photographs to sieves. Many samples also have a bend at $4 \phi$; these bends indicate the change from sieve to pipette analysis. Many of the plots have bends at $7 \phi$ that indicate the relative paucity of material in the size range of 2 to $8 \mu \mathrm{m}$ (7申 to $9 \phi)$. The bends in the plots between $2 \phi$ and $-3 \phi$ result from the bimodal nature of many of the distributions.

Murai (1961) suggested that detailed studies of "dry mudflow" (large volcanic debris avalanche) deposit would show that their grain-size distributions closely conform to the Rosin-law distribution. The data from this detailed study suggest otherwise. In nearly every sample, the distribution curves plot closer to a straight line on the normal probability plot than on the Rosin-law plot (fig. 54). For all the samples, the Rosin-law curve shows a concave upward trend, generally both overall and between the bends discussed in the preceding paragraph.

Plots of the distributions of the type 2 unimodal samples, those that have their peak in a size class coarser than $-2 \phi$, more closely approximate a straight line on the Rosin-law plot (fig. 54C) than the Rosin-law plots of the other types of samples (fig. 54A and 54B). However, even type 2 unimodal samples plot closer to a straight line on the normal plot than on the Rosin-law distribution.

The second type of unimodal samples are in the modern dacite and the andesite and basalt units, the coarsest units in the debris-avalanche deposit (table 5). The coarseness of the units probably explains the absence of a $-1 \phi$ to $3 \phi$ peak; indeed there is a bump but not a peak on the histograms from DXS-14 and DXS-25 between $-1 \phi$ and $3 \phi$. The missing peak is probably the reason that these samples come the closest to approximating a Rosinlaw distribution in the debris-avalanche deposit.

\section{STATISTICAL PARAMETERS}

Median grain diameter $\left(\mathrm{Md}_{\phi}\right)$ plotted against Inman sorting coefficient $\left(\sigma_{\phi}\right)$ is commonly used to discriminate between different types of volcaniclastic deposits (Walker, 1971; Fisher and Schmincke, 1984). The debris avalanche has Inman sorting values (2.17 $\phi-4.19 \phi)$ comparable to those of pyroclastic flow deposits analyzed by Walker (1971). Although there is considerable overlap in the values of $\mathrm{Md}_{\phi}$ between the fields for the debris-avalanche deposit and pyroclastic flow deposits, the data show that the Mount St. Helens' debris-avalanche deposit generally has coarser values of median grain size than do pyroclastic flow deposits (although some of Walker's samples probably do not include material too coarse to sieve) but has roughly the same sorting values (fig. 55). Comparing my debris-avalanche data with tabular data for lahars compiled by Fisher and Schmincke (1984) shows that many samples from the debris avalanche are better sorted than the samples from lahars; this difference in sorting probably indicates that many debris avalanche samples are derived from well-sorted volcaniclastic materials. Samples from the debris avalanche also are generally better sorted and finer grained than samples from the lahars on the southwest flank of Mount St. Helens that were studied by Major and Voight (1986); the difference 


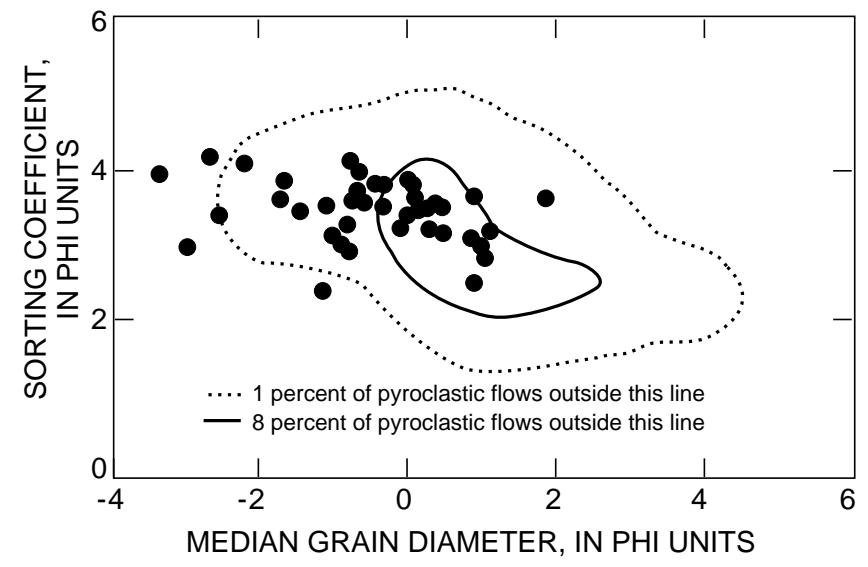

Figure 55. Median diameter versus sorting coefficient. Field for pyroclastic flow from Walker (1971). Field from Walker does not include material too coarse to sieve.

probably indicates that the debris avalanche samples were shattered during transport and that many samples were derived from well-sorted volcaniclastic materials.

A ternary diagram (fig. 56) of gravel, sand, and mud (silt+clay) graphically shows the range of grain-size distributions in the debris-avalanche deposit. Gravel ranges from 22.0 to 92.3 weight percent and has a mean of 45.5 percent; the extreme value represents an intact platyjointed dome breccia (DXS-12; figs. 34 and 50). Sand ranges from 6.6 to 65.4 percent and has a mean of 44.8 percent. Mud ranges from 1.1 to 21.2 percent and has a mean of 9.7 percent. Fields of the various map units show considerable overlap. The mixed block and matrix facies unit, not surprisingly, lacks the extreme values of the other units.

Fisher and Schmincke (1984) plot the preliminary data for the debris-avalanche deposit from Voight and others (1981) on a triangular plot of sand, silt, and clay. Plotting only the size fractions smaller than gravel eliminates the uncertainties involved with material too coarse to sieve. The data from this report (fig. 56) show significantly less clay than the preliminary data; the difference is probably because the preliminary data were generated by the hydrometer technique, which is less accurate than the pipette analysis used in this report (Folk, 1974; Wayne Steuben, U.S. Geological Survey, oral commun., 1984). These data should not be compared to the field of the Mount St. Helens' blast deposit plotted on Fisher and Schmincke's figure 11-5, because the blast deposit data, obtained from Voight and others (1981), were from samples of the uppermost part of the blast deposit (upper A2 of Waitt, 1981), which is atypical of most of the blast deposit.

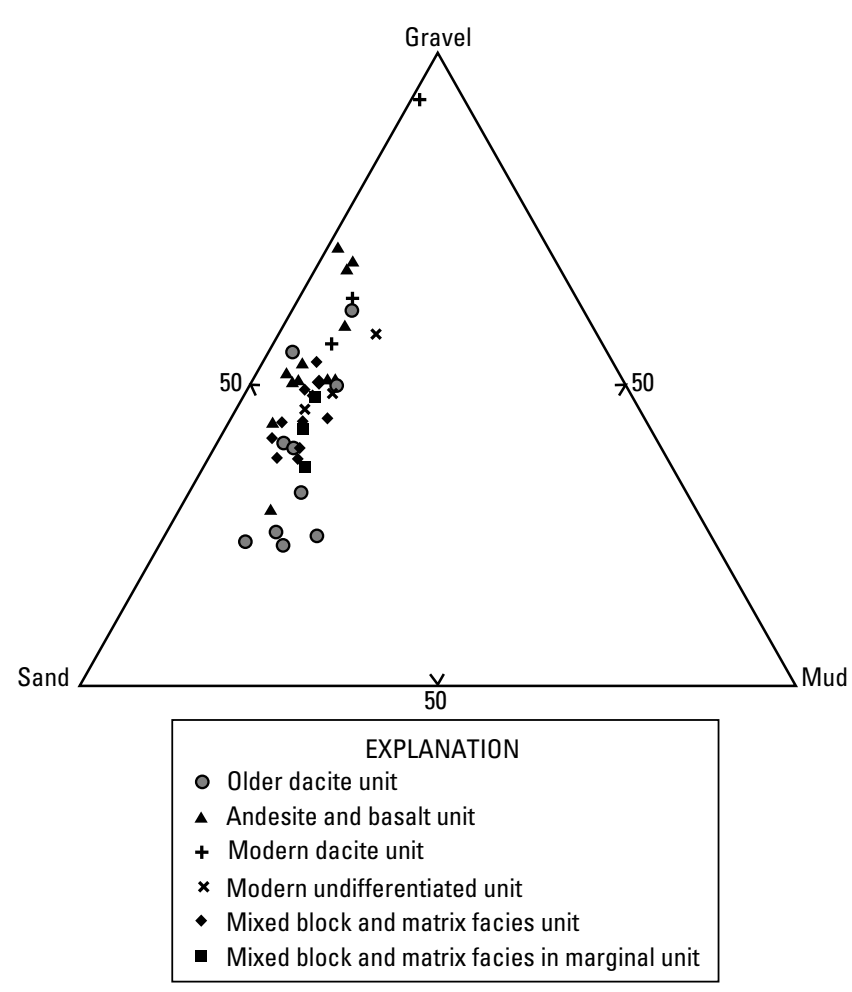

Figure 56. Triangular plot of percentages of gravel, sand, and mud for samples in debris-avalanche deposit.

\section{LATERAL VARATIONS OF STATISTICAL PARAMETERS}

Measurements of median diameter $\left(\mathrm{Md}_{\phi}\right)$ and mean diameter computed by method of moments $\left(\mathrm{Mn}_{\mathrm{m} \phi}\right)$ are the average size of the clasts in each sample. As shown in figure 57, these parameters are highly variable near the source, but at more than $20 \mathrm{~km}$ from the source, mean diameter and median diameter values cluster around the mean values for the whole deposit for each parameter, $0.65 \phi$ and $-0.54 \phi$.

Other size parameters were plotted against distance from source to detect systematic trends. Percentages of gravel, sand, and mud (silt+clay; material finer than $4 \phi$ ) are plotted against distance from source (fig. 58). As with mean and median values, there is great variability close to the source, and in the distal parts of the deposit the percentages of gravel, sand, and mud cluster about mean values ( 45.5 percent, 44.8 percent, and 9.7 percent, respectively).

Each map unit that consists entirely of block facies has a distinct field of values on the grain-size plots (figs. 57 and 58). The grain-size within the blocks reflects the values of the original material on the mountain, although the shattering has reduced the sizes of the larger clasts. The finer grained debris-avalanche blocks (for example, older dacite windows 825-3 and DXS-20; fig. 50) probably were fine-grained tephra or material that was thor- 

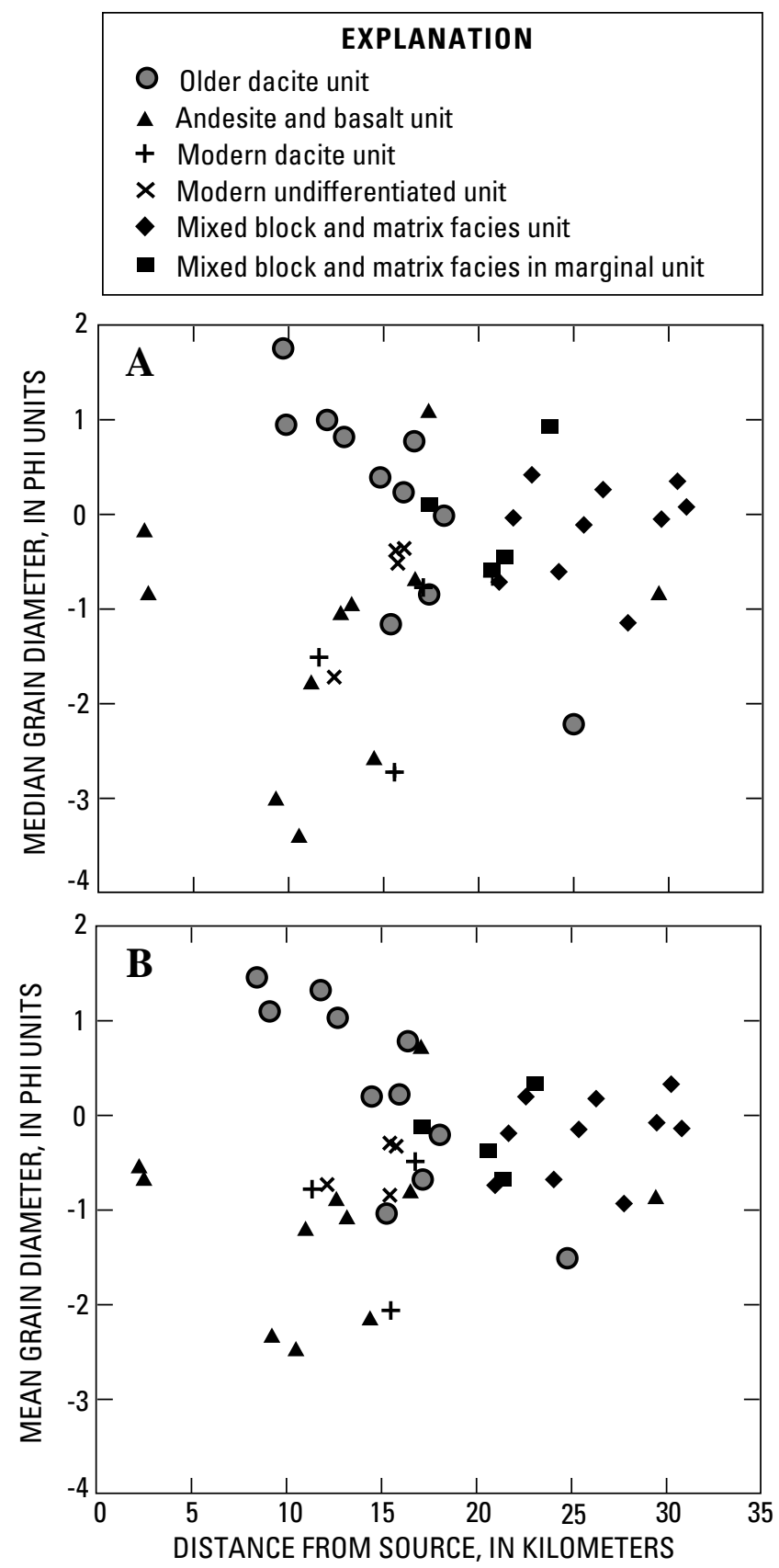

Figure 57. Computed size parameters versus distance from source. Plots do not include anomalously coarse-grained DXS-12 (fig. 34). A, Median grain diameter, measured in phi units, versus distance from source. B, Mean grain diameter computed by method of moments, measured in phi units, versus distance from source.

oughly hydrothermally altered on the original mountain. The coarser debris-avalanche blocks (for example, windows DXS-12, 827-2; fig. 50) are interpreted to originate from coarse-grained volcaniclastic deposits, lava flows, or domes. However, it is apparent from comparisons of exposures inside the crater with the windows in the deposit (fig. 50) that shattering has significantly reduced the number of clasts in the deposit larger than $-5 \phi$.
If a significant quantity of clasts were fractured during transport, the deposit should become finer grained in distal areas. This would be expressed by progressive decreases in $\mathrm{Md}_{\phi}, \mathrm{Mn}_{\mathrm{m} \phi}$, and percentages of gravel, and by progressive increases in percentages of sand and mud. The absence of these trends indicates that fracturing of clasts did not occur progressively during transport. This is interpreted to mean that fracturing of large clasts of the old mountain occurred mainly at the source, as is also suggested by the density data. Clast-to-clast collisions that resulted in fracturing surely did occur during transport, but not enough of this occurred to significantly affect the grain-size distribution within the debris-avalanche deposit.

Information from grain-size data confirms the conclusions reached by study of the windows. The clustering of data about the mean for all the grain-size parameters in the distal areas suggests that much of the matrix facies material of the distal areas formed by disaggregation and mixing of debris-avalanche blocks of different grain-size characteristics. Converging grain-size trends suggest that this occurred during the flow of the debris avalanche. However, there are no blocks of juvenile dacite in the avalanche deposit, so the presence of clasts of juvenile material in the matrix facies in the distal areas (table 3) indicates that a process other than disaggregation and mixing also contributed to the production of matrix facies. This process was probably the explosions of the cryptodome (the blast) bursting through slide blocks II and III; it is more fully described in "Conclusions".

Sorting parameters also suggest disaggregation and mixing of debris-avalanche blocks. A plot of sorting coefficient $\sigma_{\mathrm{m} \phi}$ (standard deviation computed by the method of moments) related to distance from source (fig. 59) shows that the deposit does not get systematically better or more poorly sorted with distance from source. The sorting values range from 2.66 to 4.13 within $20 \mathrm{~km}$ of the source and approach a mean of 3.47 more than $20 \mathrm{~km}$ from the source although the trend is not so pronounced as in figures 57 and 58 .

\section{CONCLUSIONS}

The geology of the old mountain as mapped by C.A. Hopson (written commun., 1980) and the distribution of the map units within the debris avalanche enable interpretations to be made of the resting places of the various parts of the old mountain that were mobilized during the eruption. These interpretations are revised substantially from those of Voight and others (1981, 1983); their interpretations were made without the benefit of a lithologic map. The morphologic and lithologic maps (pls. 3 and 4; 

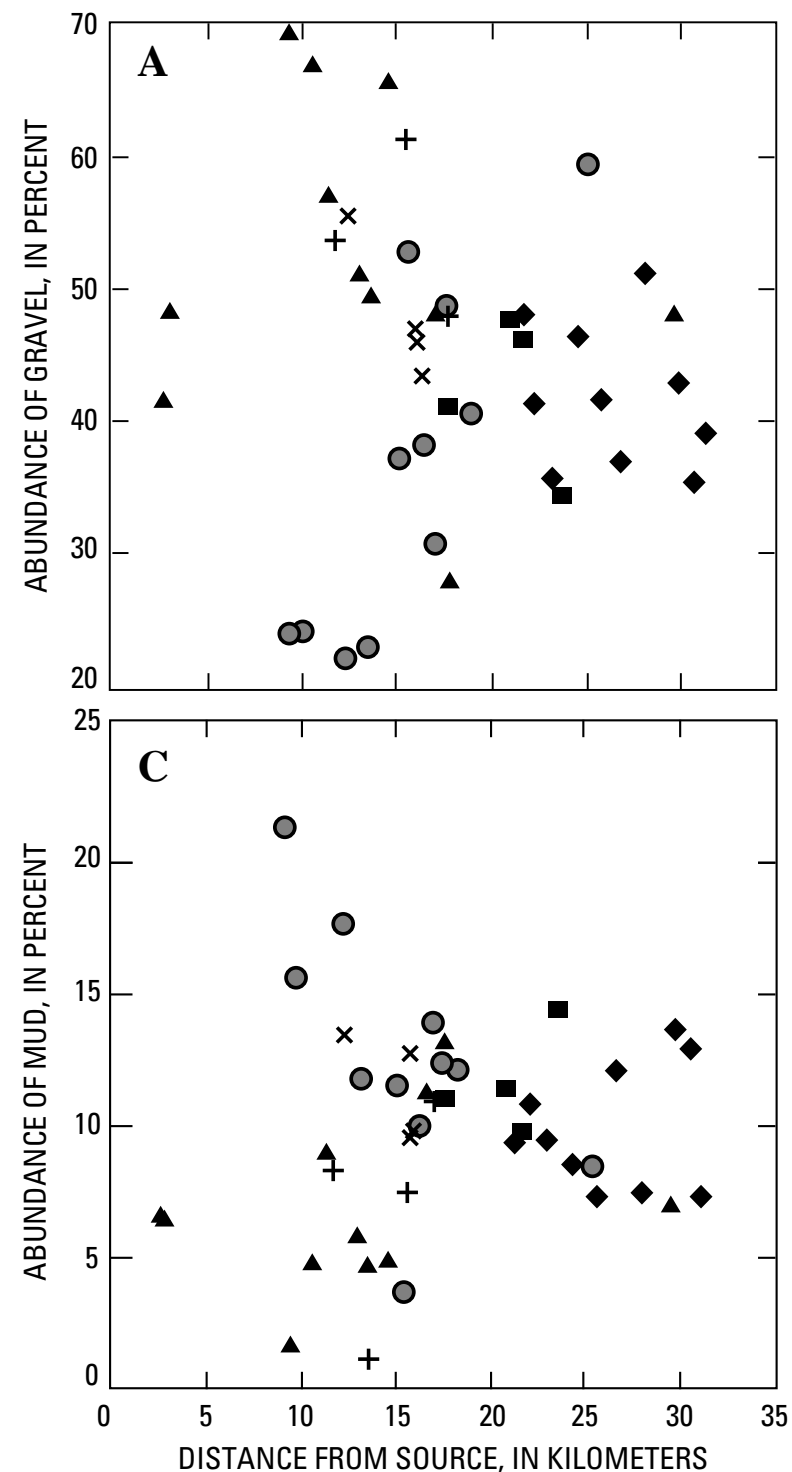

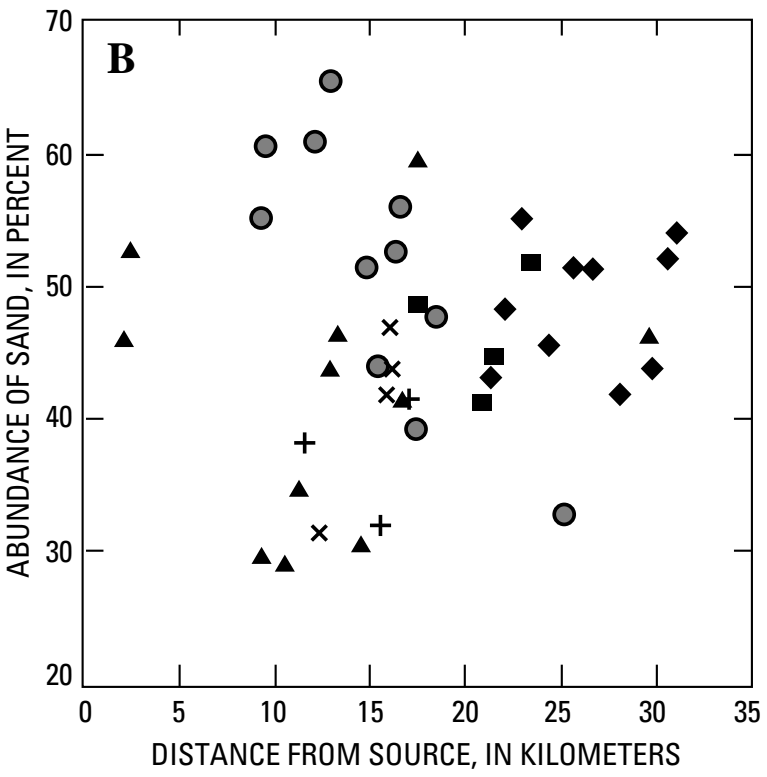

\section{EXPLANATION}

O Older dacite unit

- Andesite and basalt unit

+ Modern dacite unit

$\times$ Modern undifferentiated unit

- Mixed block and matrix facies unit

- Mixed block and matrix facies in marginal unit

Figure 58. Percentage of size classifications versus distance from source. A, Percent gravel versus distance from source. Does not include coarse-grained DXS-12 (fig. 34). B, Percent sand versus distance from source. C, Percent mud (silt+clay) versus distance from source.

fig. 60) help in the construction of an interpretation of the initial events of the eruption, an interpretation based primarily on a study of eyewitness photographs. In addition, evidence from the texture and morphology of the deposit enables interpretations of how the volcano broke into the slide blocks of the rockslide, broke into smaller debris-avalanche blocks, moved down the valley as a flowing debris avalanche, and was finally deposited (fig. 61). Mathematical modeling is not attempted here; interpretations are made by drawing inferences directly from the field and laboratory data.

\section{SLIDE AND BLAST EVENTS}

\section{SLIDE BLOCK I}

The initial movement of the rockslide-debris avalanche is interpreted as a series of retrogressive slope failures (Voight and others, 1983) based on examination of eyewitness photographs (Voight, 1981). The first failure of the series, called slide block I, began to slide northward from the summit of the mountain about $10 \mathrm{~s}$ after the 8:32.2 a.m. earthquake on May 18 (Voight and others, 1983). On the basis of an analysis of photographs (Voi- 


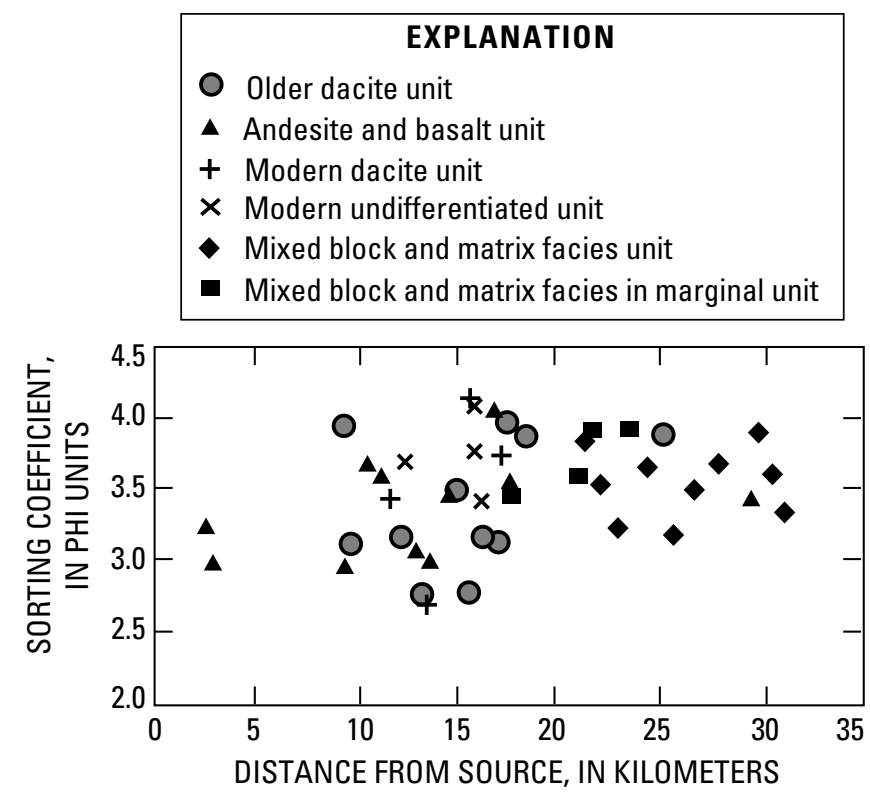

Figure 59. Sorting coefficient computed by method of moments, measured in phi units, versus distance from source.

ght, 1981), the slide block reached a maximum velocity of about $80 \mathrm{~m} / \mathrm{s}$.

Slide block I represents about 32 percent of the volume of the total rockslide. Forty-two percent of the slide block was andesite and basalt (table 2). The andesite and basalt unit was underlain by older dacite (52 percent of the volume of the slide block) and was intruded by modern dacite (6 percent of the volume of the slide block).

The debris-avalanche deposit on and adjacent to Johnston Ridge (the Johnston Ridge unit of morphologic map; pl. 3) is interpreted (figs. 60 and 62) to have formed from slide block I. The deposit, which is composed primarily of andesite and basalt (fig. 60), sharply overlies older dacite at or near the base of Johnston Ridge. This composition is consistent with the composition of slide block I. The sharp contacts between the two units commonly show evidence that they are original volcanic contacts. Although the slide block was shattered, much of it apparently slid into position without tumbling, preserving the andesite and basalt/older dacite contact at the bottom of the ridge.

A velocity of 50 to $70 \mathrm{~m} / \mathrm{s}$ was calculated for the velocity of the moving material at the bottom of Johnston Ridge (Glicken and others, 1981; Voight and others, 1983); the value is based on the height the debris traveled up the ridge. These velocities were calculated from the relation $v=(2 g h)^{1 / 2}$, where $h$ is runup height. The range of velocities results from uncertainty regarding the runup height, and the velocities represent minimum values because the method does not consider frictional dissipation of the slide block's kinetic energy.
Some of slide block I was deposited in Spirit Lake; $0.43 \mathrm{~km}^{3}$ of material (Meyer and Carpenter, 1982) moved into Spirit Lake and caused a seiche that resulted in lake runup of $260 \mathrm{~m}$. The clear path from the mountain to the lake, the andesite and basalt composition of the hummocks adjacent to the lake (fig. $60 ; \mathrm{pl} .4$ ), and the relations of the scour caused by lake runup to the deposits of the pyroclastic current of the lateral blast (R.B. Waitt, U.S. Geological Survey, written commun., 1985) strongly suggest that much of the debris-avalanche deposit in Spirit Lake is from slide block I. Because the water from the lake did not flow down the North Fork Toutle River, the lake must have been dammed immediately by the debris avalanche. This provides further evidence that the Johnston Ridge unit, which dams Spirit Lake, was part of slide block I.

Other parts of slide block I made a $90^{\circ}$ left turn and traveled down the North Fork Toutle River valley. This material was broken into smaller blocks and became a flow of debris-avalanche blocks. The abundance of andesite, basalt, and modern dacite in the marginal unit and in the levees at the junction of the North Fork Toutle River valley with Coldwater Creek, Maratta Creek, and the area between Studebaker and Castle Creeks identifies them as parts of slide block I. The andesite, basalt, and modern dacite are the top part of slide block I; the core of slide block I is primarily older dacite (fig. 2). The distribution of rock types suggests that the top part of slide block I was pushed from behind and aside by material from the lower part of slide block I, as well as by material from subsequent slide blocks, and deposited on the margins of the valley. A similar process of deposition, where material at the front of a flow is pushed to the sides of the flow by material from behind, is commonly observed during the flow of small, coarse-grained debris flows (Sharp, 1942), and during flow of large-scale experimental debris flows (Major, 1996).

\section{SLIDE BLOCK II AND BLAST SURGE}

The cryptodome and its surrounding hydrothermal system were unroofed by the first slide block, and the resulting rapid depressurization resulted in the initial explosions of the lateral blast (Kieffer, 1981). Meanwhile, retrogressive failure continued; eyewitness photographs show that a slip surface formed just behind the summit crater and propagated downward, forming the base of the mass called slide block II. The initial blast explosions burst through slide block II and produced a pyroclastic surge (the "blast surge" of Fisher and others, 1987) that quickly overran the first slide block, devastated the landscape in front of the moving slide, and deposited the stratified pyroclastic material known as the 


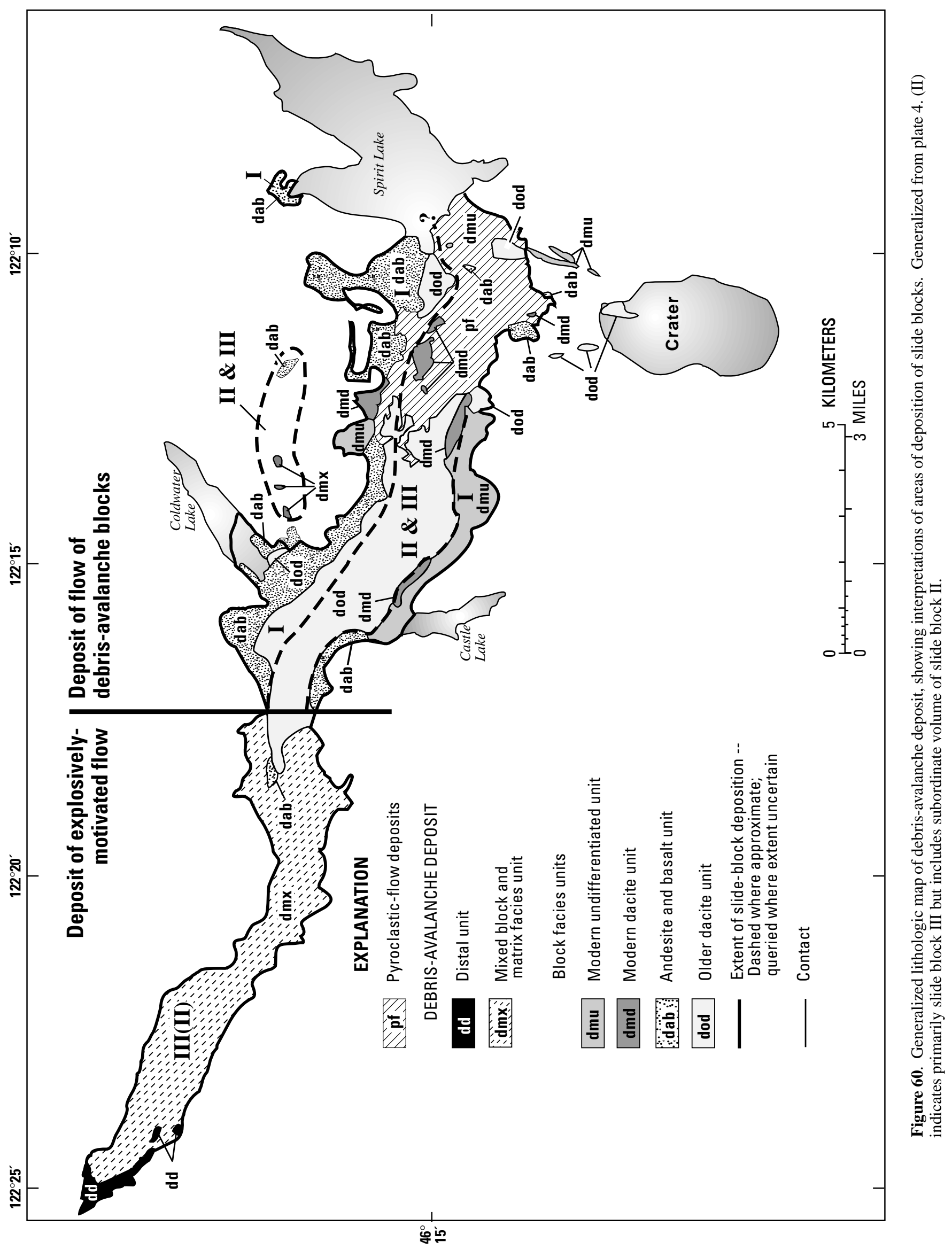

76 Rockslide-Debris Avalanche of May 18, 1980, Mount St. Helens volcano, Washington 


\begin{tabular}{|c|c|c|}
\hline SCHEMATIC REPRESENTATION & PROCESS & EVIDENCE \\
\hline \multirow{7}{*}{ 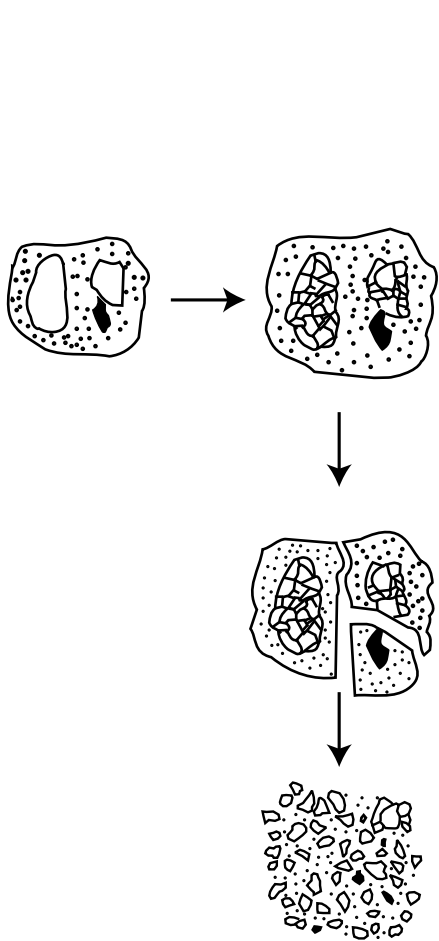 } & \multicolumn{2}{|c|}{ At mountain } \\
\hline & $\begin{array}{l}\text { Rockslide-slide block I. } \\
\text { Slide blocks II and III-blast. }\end{array}$ & $\begin{array}{l}\text { Eyewitnesses, } \\
\text { seismic record. }\end{array}$ \\
\hline & Dilation, clasts shatter. & Density measurements. \\
\hline & \multicolumn{2}{|c|}{$\begin{array}{lll}\text { TRANSITION TO DEBRIS-AVALANCHE FLOW } \\
\end{array}$} \\
\hline & \multicolumn{2}{|c|}{ During debris-avalanche flow } \\
\hline & $\begin{array}{l}\text { Blocks break into smaller } \\
\text { blocks. }\end{array}$ & $\begin{array}{l}\text { Mapping, } \\
\text { block measurements }\end{array}$ \\
\hline & $\begin{array}{l}\text { Blocks disaggregate and } \\
\text { mix. }\end{array}$ & Clast size, exposures. \\
\hline
\end{tabular}

Figure 61. Summary of processes involved in transport of rockslide-debris avalanche.

blast deposit over ridges and valleys across an area of 550 $\mathrm{km}^{2}$ (Hoblitt and others, 1981).

The initial velocity of the front of the blast surge was calculated from timed photographs to be $90 \mathrm{~m} / \mathrm{s}$ (Moore and Rice, 1984), approximately the sonic velocity of the material (Kieffer, 1981). Modeling by Kieffer (1981) suggests that the velocity of the material may have reached a maximum of $325 \mathrm{~m} / \mathrm{s}$ due to lateral expansion. Because the surge was supersonic, it was not deflected much by topography in the "channelized blast zone", within $11 \mathrm{~km}$ north of the crater (Kieffer, 1981).

Slide block II is 56 percent older dacite, 25 percent modern dacite, 11 percent andesite and basalt, and 8 percent cryptodome dacite. Part of slide block II became part of the blast surge, but because the blast surge deposit has a bulk volume of $0.2 \mathrm{~km}^{3}$ (Moore and Sisson, 1981) no more than 27 percent of the $0.75 \mathrm{~km}^{3}$ slide block (table 3 ) is present in the blast surge deposit. The balance must have been deposited in Spirit Lake, in the North Fork Toutle River valley, or in South Coldwater Creek.

Moore and Rice (1984) propose that the initial explosions visible on many photographs were smaller than a discrete explosion that occurred near Spirit Lake at approximately 8:34.3 a.m. They base their interpretation on Department of Defense satellite data that show intense emissions of heat between 8:33.3 and 8:34.4 a.m., on the pattern of tree blowdown and blast surge deposition that emanates from the area north of the crater, and on photographs from east of the mountain that show that a cloud of pyroclastic material rose from the area near Spirit Lake at about 8:34.3 a.m. However, both the pattern of tree blowdown and the heat emission can be explained by Kieffer's (1981; also oral commun., 1984) model of the blast surge as a single, expanding supersonic flow of pyroclastic debris. The cloud of pyroclastic material rising from near Spirit Lake may have resulted in part from continuing explosions of the cryptodome as it moved down the mountain in slide block II, but Sisson $(1982,1995)$ suggests that it is primarily a cloud of elutriate that developed from the thick blast deposits in the Spirit Lake and South Coldwater Creek areas. As all the evidence presented to support the model of Moore and Rice is ambiguous, and there is nothing in the geology of the deposits in the North Fork Toutle River to support their idea, it is not adopted for this work.

\section{SLIDE BLOCK III}

The blast explosions produced a cloud of pyroclastic debris that obscured the north part of the mountain about 1 minute after the initial earthquake (Voight, 1981). No more slope movements are observed in eyewitness 


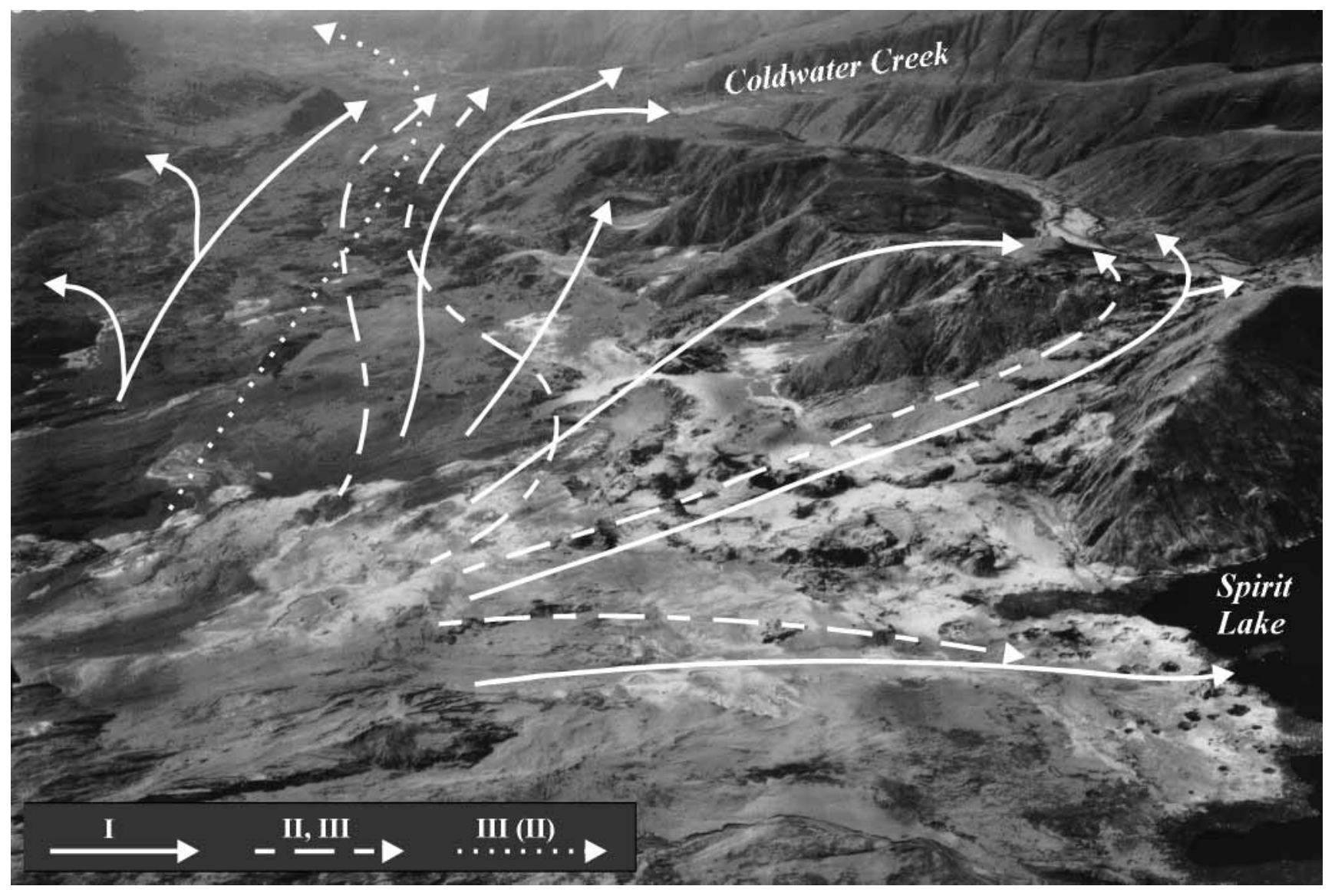

Figure 62. Oblique aerial photograph, looking west from Spirit Lake. Arrows show interpreted paths of slide blocks. Dotted line shows trace of slide block III, deposited first, and slide block II, deposited over slide block III material. Photograph by Austin Post, U.S. Geological Survey, June 4, 1980.

photographs after this time. Moore and Rice (1984) state that a major collapse of the south crater rim occurred at 8:33.4 a.m., but their inference is based only on a change in the morphology of the eruption cloud observed on a videotape (S.G. Malone, University of Washington, written commun., 1984). However, explosions resulting from the depressurization of parts of the cryptodome were observed to continue, possibly as new parts of the cryptodome were exposed by continuing mass movements.

These continuing mass movements are collectively called slide block III. Slide block III consisted of many discrete failures; it is likely that the blocks of material from these failures were, at least in part, transported by pyroclastic currents that were generated from the continuing blast explosions.

After the explosively generated pyroclastic currents and debris-avalanche blocks of slide block III moved out of the crater and down the north flank, they were strongly deflected by topography, resulting in velocities that were less than sonic (Kieffer, 1981) and were considerably slower than the initial blast surge. Depressurization of the cryptodome continued, but the change in character of the pyroclastic current generated from the depressurization suggests that material was erupted at a slower velocity and at a lower rate than at the start of the blast explosions.

Some of the slide block III material may have moved into Spirit Lake to become part of the $0.43 \mathrm{~km}^{3}$ of material filling Spirit Lake, and some may have moved over passes on Johnston Ridge (Fisher and others, 1987), depositing as the $0.06 \mathrm{~km}^{3}$ of mixed block and matrix facies unit ("avalanche II" of Fisher and others, 1987) in South Coldwater Creek, but most of the $1.3-\mathrm{km}^{3}$ slide block flowed down the valley of the North Fork Toutle River. Some of the debris-avalanche blocks were deposited as lithologic units of the block facies that are mapped east of the break-in-slope west of Maratta Creek, and some of the pyroclastic currents were deposited as matrix facies (which contains juvenile material) east of the break-in-slope. The balance of the material from slide block III was deposited as the mixed block and matrix facies unit west of the break-in-slope near Maratta Creek. 


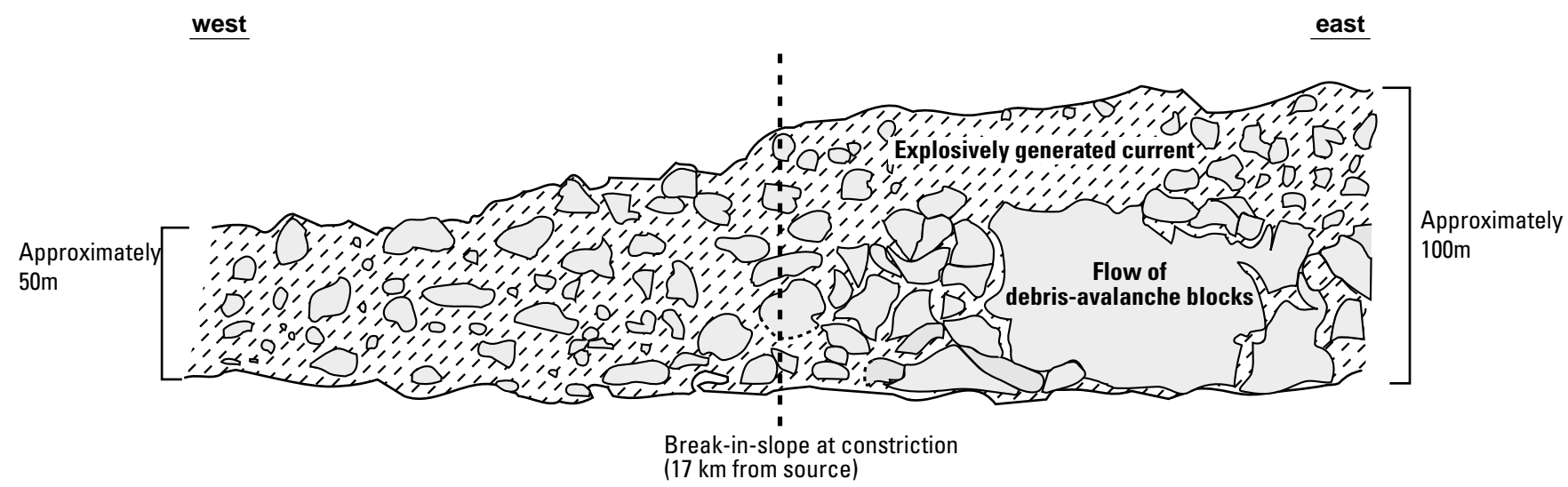

EXPLANATION

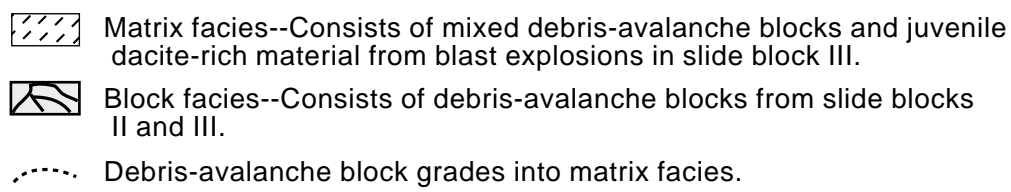

Figure 63. Schematic cross sectional diagram showing flow of debris-avalanche blocks and the production of matrix facies from disaggregation and mixing of debris-avalanche blocks and from the pyroclastic current generated from blast explosions of slide block III.

The time of deposition and the composition of the mixed block and matrix facies material of the western part of the debris avalanche (fig. 60) are consistent with an origin from slide block III. Stratigraphic relations (see "Geologic Maps of the Deposit"; fig. 37) indicate that the bulk of the mixed block and matrix facies material of the western part of the debris-avalanche deposit traveled over the top of the flow of debris-avalanche blocks of the eastern part of the debris avalanche, and it was thus the last avalanche material to be deposited. The juvenile clasts and the mixed character of the material suggest that the matrix facies represents, at least in part, the deposit of pyroclastic currents generated from the blast explosions that likely originated from slide block III (fig. 63). The matrix facies carried, and is interconvoluted with, debrisavalanche blocks that probably originated from slide block III. The $1.3-\mathrm{km}^{3}$ volume of the slide block (table 3 ) is more than enough to account for the $0.5-\mathrm{km}^{3}$ volume of the mixed block and matrix facies in the western part of the deposit.

Some of the material of the western part of the debris-avalanche deposit may have originated from slide block II. Disaggregation and mixing of debris-avalanche blocks from slide block II (in the flow of debris-avalanche blocks of the eastern part of the avalanche deposit) likely created matrix facies. This matrix facies probably mixed with juvenile dacite-rich matrix facies derived from the blast explosions of slide block III, and nearly all the matrix facies flowed to the western part of the ava- lanche deposit (fig. 63). The blast explosions of slide block II probably generated only a minor proportion of the juvenile-dacite-rich matrix facies because most of the slide block II explosions are observed in the photographs forming the blast surge that spread over the ridges and felled trees to the north of the mountain.

\section{FINAL EVENTS}

After nearly all the material from slide block III moved out of the crater and down the flank of the mountain, the magma continued to depressurize. The depressurizing magma produced blast pyroclastic currents. These currents traveled down the North Fork Toutle River valley and were deposited as blast deposits that rest on top of the avalanche in the $10 \mathrm{~km}$ of the valley west of the Pumice Pond (figs. 39 and 41). These currents, generated from the final depressurization, were strongly deflected by topography, as they were not able to surmount Spirit Lake Blockage or Johnston Ridge. Thus, they were subsonic (Kieffer, 1981), much slower than the initial blast surge.

The good morphologic and stratigraphic evidence that suggests that the bulk of these blast deposits were deposited after the avalanche $10 \mathrm{~km}$ west of Pumice Pond came to rest indicates that the blast explosions (the depressurization of the remaining parts of the cryptodome) continued to generate pyroclastic currents for at least 3 to 4 minutes after the beginning of rockslide and blast events. Deposition of the entire debris ava- 
lanche took about 10 minutes; this time period is based on the length of time the seismic record was saturated by an earthquake generated from the transport of the avalanche (Voight and others, 1983). However, parts of the avalanche deposit $10 \mathrm{~km}$ west of Pumice Pond were likely deposited within about 3 to 4 minutes of the trigger earthquake; this time period is based on calculations of the velocity of the debris avalanche material (Voight and others, 1983).

Some of the proximal unit of the debris-avalanche deposit that fills the bottom of the crater is not covered by blast deposits. It may be younger than the final blast explosions, or the blast deposits may have been eroded away by the pyroclastic flows of May 18 . The unstable walls of the newly formed crater probably slumped to form the proximal unit in the crater. The slumping may have continued throughout the morning of May 18. The crater-fill material is covered by pyroclastic-flow deposits of the afternoon of May 18.

\section{WATER BUDGET}

Mount St. Helens receives about 3.3 m mean annual precipitation (Gullidge, 1970), so water may be expected to play an important role in any mass movement. Ground water in the volcanic edifice, which includes meteoric water and water from the magma body, shattered glacial ice, and water picked up from lakes, streams, and ground water in the North Fork Toutle River valley were the sources of the water in the debris avalanche (table 6). Some water was lost after deposition of the debris avalanche when lahars were formed, but most of the water remained in the pore spaces of the debris avalanche (table 6).

The amount of water within the part of the mountain that became the debris avalanche (the source material) includes both the ground water in the saturated zone underneath the water table and the ground water in the unsaturated zone above the water table. The volume of the source material is calculated to be $2.1 \mathrm{~km}^{3}$, which represents the $2.5-\mathrm{km}^{3}$ volume of the debris-avalanche deposit (not including the proximal unit) corrected for 20-percent dilation (see "Texture of the Deposit").

The volume of water in the saturated zone is the product of the porosity and the volume of source material beneath the water table. Water table II of figure 19 of Voight and others (1983) is assumed to be a reasonable representation of the water table within the old volcanic edifice. The cross section suggests that roughly 85 percent of the volume of the material missing from the crater was under the water table. The crater includes the source material for the debris-avalanche and blast deposits as well as the lithic components of the air-fall deposits, but because the source material for the debris-avalanche deposit makes up the bulk of the missing material, I assume roughly 85 percent of it to be under the water table also. The porosity of the source area is determined to be 14 percent by the equation

$$
n=1-\frac{\rho_{f}}{\rho_{g}}
$$

where $n$ is the porosity of the material; $\rho_{f}$ is the mean field density $\left(2.31 \mathrm{~g} / \mathrm{cm}^{3}\right.$; table 5); and $\rho_{g}$ is the mean grain density $\left(2.7 \mathrm{~g} / \mathrm{cm}^{3}\right.$; laboratory determination; Voight and others, 1983).

The total volume of water in the saturated part of the mountain that became the rockslide-debris avalanche was therefore

$$
V_{w s}=n \times V_{m s}=0.25 \mathrm{~km}^{3}
$$

where $\mathrm{V}_{w s}$ is the volume of water in saturated zone, and $\mathrm{V}_{m s}$ is the volume of source material in the saturated zone $\left(1.8 \mathrm{~km}^{3}\right)$. Some of the water may have been in the form of steam adjacent to the magma body, but the lithostatic load on the water probably kept most of it in the liquid phase.

The unsaturated zone may be estimated to be roughly 50 percent saturated (for example, Gillham, 1984, fig. 6). The volume of water in the unsaturated part of the mountain that became the rockslide-debris avalanche is then computed as

$$
V_{w u}=0.5 \times n \times V_{m u}=0.02 \mathrm{~km}^{3}
$$

where $\mathrm{V}_{w u}$ is the volume of water in the unsaturated zone and $\mathrm{V}_{m u}$ is the volume of source material in the unsaturated zone (equal to the total volume of source material minus the volume of saturated zone; $0.3 \mathrm{~km}^{3}$ ).

Glacial ice may have contributed liquid water to the movement. However, for this to occur, the ice must have melted during the movement of the debris avalanche. The debris avalanche was warm enough (as much as $98{ }^{\circ} \mathrm{C}$; Voight and others, 1981) to melt ice, but in order for melting to occur, the ice must have been thoroughly shattered or adjacent to a substantial source of heat. It is likely that ice would shatter (as did clasts in the debris avalanche). However, chunks of ice meters wide were observed on the surface of the deposit for a few weeks after emplacement, and ice was dug up in excavations for a trench dug by the 
Table 6. Water budget of debris avalanche

[Most calculations, references in text. All values in $\mathrm{km}^{3}$. Assumes $2.5-\mathrm{km}^{3}$ debris-avalanche deposit (not including proximal unit in crater and on north flank) and $2.1-\mathrm{km}^{3}$ source of debris avalanche]

\section{Sources of water (maximum contributions)}

\begin{tabular}{ll}
\hline Ground water in saturated zone of old mountain & 0.25 \\
Ground water in unsaturated zone of old mountain & 0.02 \\
Glacial ice & 0.10 \\
Total & 0.37
\end{tabular}

About $0.43 \mathrm{~km}^{3}$, or 17 percent of the debris avalanche, was deposited in Spirit Lake, so the total water available for the debris avalanche (not including the material deposited in Spirit Lake) is 83 percent of $0.37 \mathrm{~km}^{3}$

Total available

All of the $0.06-\mathrm{km}^{3}$ decrease in the volume of Spirit Lake is assumed to be incorporated in the debris-avalanche deposit in the lake (see text).

Maximum volume percent of water in deposit (not including $0.4 \mathrm{~km}^{3}$ of deposit in lake) (value obtained from $0.31 \mathrm{~km}^{3} / 2.1 \mathrm{~km}^{3}$ )

\section{Depletion of water}

Lahars 0.06

Balance remaining in deposit

Maximum volume percent of water in deposit after loss to lahars

(not including $0.4 \mathrm{~km}^{3}$ of deposit in lake; value obtained from $0.25 \mathrm{~km}^{3} / 2.1 \mathrm{~km}^{3}$

U.S. Army Corps of Engineers near Spirit Lake almost 2 years after emplacement; this subsurface ice indicates that much of the ice did not melt during transport.

The maximum amount of water that could have been contributed to the debris avalanche by glacial ice is calculated to be about $0.10 \mathrm{~km}^{3}$ (table 6). The total volume of glacial ice removed during the May 18 eruption (Brugman and Meier, 1981) was $0.13 \mathrm{~km}^{3}$. Probably about half of the $0.035 \mathrm{~km}^{3}$ of ice removed from the Forsyth Glacier (Brugman and Meier, 1981) was removed in the Forsyth ice avalanches that were not involved with the debris avalanche (Voight, 1981). Thus about $0.11 \mathrm{~km}^{3}$ of ice was incorporated in the debris avalanche; this amount is equivalent to $0.10 \mathrm{~km}^{3}$ of water, assuming the density of ice to be 92 percent of the density of water.

A calculation based on a bathymetric survey shows that the volume of Spirit Lake decreased by $0.06 \mathrm{~km}^{3}$ during the eruption (Meyer and Carpenter, 1982). Most of this water was probably incorporated in the $0.43 \mathrm{~km}^{3}$ of debris avalanche that went into Spirit Lake. Voight and others (1983) show that the debris-avalanche deposit has a mean porosity of roughly 32 percent, so the water capacity of the debris-avalanche deposit under Spirit lake is $0.14 \mathrm{~km}^{3}$, more than enough to account for the missing $0.06 \mathrm{~km}^{3}$. An unknown but probably substantially smaller volume of water was probably picked up from the
North Fork Toutle River and from ground water in the alluvium of the North Fork Toutle River valley.

About $0.14 \mathrm{~km}^{3}$ of lahars (Fairchild and Wigmosta, 1983; Fairchild, 1985, 1987) were produced throughout the day of May 18 from water-rich parts of the debrisavalanche deposit (see "Geologic Maps of the Deposit"). Fairchild $(1985,1987)$ estimates that they contained 3550 percent water. They were apparently richer in water than those on the east side of the volcano, which were estimated to contain 22-36 percent water by volume (Pierson, 1985), and those on the southwest flank, which were estimated to contain 30-37 percent water by volume (Major, 1984), but this difference may be due to different methods of determining water content. Fairchild's average of 42 percent water is used to compute a water volume of about $0.06 \mathrm{~km}^{3}$ in the lahars that were generated on the debris-avalanche deposit. Most of the $0.31 \mathrm{~km}^{3}$ of water in the debris-avalanche deposit did not become part of the lahars; the water remained in the pore space between clasts of the debris-avalanche deposit (table 6).

\section{TRANSITION TO FLOW AND DISINTEGRATION OF MATERIAL}

Eyewitness photographs show that the failure of the north side of Mount St. Helens began as a slide (displacement occurring along one or several surfaces or relatively 
narrow zones; Varnes, 1978). It is apparent from the deposit, however, that the material soon disintegrated into particles of various sizes. Part of the material from the crater was accelerated by the blast explosions and became the blast deposits, but the vast bulk of the material was driven by its own weight and took on the character of a flowing debris-avalanche as particles interacted with each other and with interstitial fluids.

The distribution of rock types and the preservation of contacts within the Johnston Ridge unit suggest that a part of slide block I slid relatively intact and without tumbling to form the Johnston Ridge unit (figs. 60 and 62). The material from the balance of slide block I did not surmount the ridge, but rather took a $90^{\circ}$ left turn and broke up into smaller pieces (debris-avalanche blocks). The debris-avalanche blocks then flowed together down the valley (figs. 60 and 62).

Photographs show that slide block II began as a simple slide, and then the blast explosions tore through the sliding material to produce the blast surge. A small amount of the remaining material went over the top of Johnston Ridge and was deposited as part of the $0.06 \mathrm{~km}^{3}$ of material in South Coldwater Creek (Fisher and others, 1987), and some went into Spirit Lake; however, most of the rest of the $0.75-\mathrm{km}^{3}$ slide block probably took a $90^{\circ}$ left turn at the base of Johnston Ridge, broke into smaller debris-avalanche blocks, and joined the flow of debrisavalanche blocks travelling downvalley (figs. 60 and 62).

Slide block III consisted of many discrete failures (Voight and others, 1983). Some of the material from these failures may have been carried away by pyroclastic currents generated from the blast explosions, but much of the material from slide block III probably also traveled down the north flank of the mountain, took the $90^{\circ}$ left turn, and became part of the flow of debris-avalanche blocks.

The flow of debris-avalanche blocks stopped just west of Maratta Creek, about $10 \mathrm{~km}$ from the $90^{\circ}$ turn and roughly $17 \mathrm{~km}$ from the center of the source of the debris avalanche in the crater (figs. 60 and 62). There, the valley of the North Fork Toutle River narrows considerably and bends to the left. The flowing debris-avalanche blocks did not make the left turn; they stopped against the valley wall just west of Maratta Creek. The break-in-slope in the avalanche deposit just west of Maratta Creek represents a part of the flow front of the flow of debris-avalanche blocks (fig. 36).

Debris-avalanche blocks that retain recognizable original volcanic stratigraphy or structures are striking but rare (see "Geologic Maps of the Deposit" and "Texture of the Deposit"). The map pattern (pl. 4) and maps of outcrops (fig. 50) indicate that debris-avalanche blocks are commonly deformed and strained over scales ranging from centimeters to hundreds of meters.

Block size in this flow of debris-avalanche blocks generally decreases with distance from source (fig. 48). The quantity of matrix-facies material increases with distance from source (fig. 50; pl. 4). Clast size, represented by median diameter, mean diameter, and percent of gravel and sand, varies considerably from site to site in proximal areas but converges about the mean for each parameter with distance from source (figs. 57 and 58). All these data taken together suggest that debris-avalanche blocks disaggregated into their constituent clasts and mixed with each other during transport. This mixing is one of the processes that created the matrix facies. However, the presence of juvenile material in the matrix facies indicates that much of the matrix facies formed from the explosions that accompanied the initial movement of slide block III (see fig. 63 and previous part of this section).

The evidence suggests that there were two types of debris-avalanche flow (fig. 63). The first is the flow of debris-avalanche blocks, made of unconsolidated pieces derived from all three slide blocks, that stopped just west of Maratta Creek, about $17 \mathrm{~km}$ from the mountain. The second is a flow of matrix facies that contained suspended debris-avalanche blocks; these suspended blocks were generated from the exploding magma body at the mountain as well as from the disaggregation of debris-avalanche blocks in the flow of debris-avalanche blocks.

The disintegration of material occurred in many different ways (fig. 61). The material dilated (increased in volume), probably due primarily to fracturing of individual clasts, but possibly also due to changes in packing of the clasts accompanying movement. As previously discussed, debris-avalanche blocks deformed, disaggregated, and mixed with each other.

Field sand-cone density measurements and laboratory measurements of the specific gravity of materials from the edifice, when compared with sand-cone measurements of the debris-avalanche deposit, indicate that the material of the old mountain dilated (increased in volume) by roughly 20 percent (table 4 ; fig. $51 B$ ). There is no trend of decreasing density in the deposit with distance (fig. $51 B$ ), and there is no trend of decreasing clast size with distance (figs. 57 and 58). This suggests that debris-avalanche blocks were dilated and large clasts were fractured during the rockslide at the mountain, rather than during transport of the debris avalanche (see "Texture of the Deposit"). Thoroughly fractured (shattered) clasts are pervasive in the debris-avalanche deposit (see "Texture of the Deposit"), which probably produced much of the dilation, although changes in packing of the clasts may account for some of it. 
Clasts in material may shatter under the tensile stress (rarefaction) that follows the compressive stress resulting from a collision. The compressive stress also generates a tensile stress approximately normal to the direction of compressive stress during a collision (Jaeger and Cook, 1979). In the rockslide, the shear generated as the slide blocks moved down irregular slip surfaces probably caused clasts in the unconsolidated slide blocks to collide and shatter at many scales (for example, Komorowski and others, 1991). In addition, clasts collided as they were forced into one another by the explosions of the blast. The shattering could not have resulted just from the blast explosions; material from slide block I, which was relatively unaffected by the blast explosions, is dilated and shattered in a manner similar to material from the other two slide blocks.

The shear at the base of the rockslide also apparently produced a seismic wave that was propagated into the mountain. Modeling of the source mechanism of the signals observed at seismographs far from the volcano indicates that the initial sliding generated strong long-period seismic waves (Kanamori and Given, 1982). Small mass movements have also been observed to produce seismic waves (Kadomura and others, 1983; Norris, 1994).

A second large earthquake about 2 minutes after the initial 8:32 a.m. event (Malone and others, 1981) may reflect the impact of the rockslide-debris avalanche against Johnston Ridge just north of the crater. Calculations based on photographs indicate that the rockslidedebris avalanche arrived at Johnston Ridge at about this time (Voight and others, 1983). The second seismic event has been interpreted by Kanamori and Given (1982) to result from the second major blast proposed by Moore and Rice (1984), but the timing of the event is equally consistent with the impact of the rockslide debris-avalanche against Johnston Ridge.

The lack of a trend of increasing dilation during transport suggests that the material was dilated to its maximum extent during sliding and was not dilated further during avalanche flow. Dilation, then, was created by sliding and resulted in profound loss of strength (Voight and others, 1983), facilitating continued sliding and the transition to avalanche flow; continued expansion of the material was not required for the avalanche to flow. Theoretical mechanics indicates that this is a general case for mass movements that begin as a slide and transform into a flow (Savage, 1984).

The deformation of the mountain caused by intrusion of the cryptodome between late March and May 18, 1980, may have caused a small amount of the dilation. The source material dilated by about 20 percent to create the $2.5 \mathrm{~km}^{3}$ debris-avalanche deposit. This 20-percent dilation is equivalent to a volume increase of $0.42 \mathrm{~km}^{3}$.
However, the "bulge" created by the deformation of the mountain between late March and May 18 had a volume of only about $0.12 \mathrm{~km}^{3}$ (Jordan and Kieffer, 1981); furthermore, most of the pre-May 18 deformation is assumed to result from intrusion of the cryptodome (Voight and others, 1983; Moore and Albee, 1981).

\section{FLUIDIZATION AND FLUIDS IN THE FLOW}

Fluidization in volcaniclastic flows is defined by Wilson (1980) and Sparks (1976) as the condition that occurs when gas is streaming up through the flow at a velocity great enough to support the weight of individual particles. This definition is drawn from the chemical engineering literature. Fluidization is defined by McSaveney (1978) as any process that turns a solid mass of loose debris into a mobile fluid; he defined mechanical fluidization as the process in which internal friction is lowered through separation of clasts in rebounds from countless collisions, and he refers to the process defined by Wilson (1980) and Sparks (1976) as gas-fluidization.

The debris-avalanche deposit is nearly everywhere poorly sorted, with $\sigma_{\phi}>1$ (table 4 ). Thus, the flowing material had a negligible amount of gas-fluidization, and the parts of it that were an explosively generated pyroclastic current may be considered type 1 pyroclastic flows of Wilson (1980). Wilson notes that features of the deposits of these events can best be explained by considering the flowing material to be a high-concentration dispersion, that is, a high-concentration flow of particles.

However, gases of various kinds were present in the interstices of the avalanche deposit. It is clear from the photographs that the sudden release of the pressure on the volcano's hydrothermal and magmatic system resulted in the transformation of ground water to steam that became incorporated in the rockslide. The fumaroles on the surface of the avalanche after emplacement reflect release of this water vapor, or additional vapor generated from the interaction of hot parts of the avalanche deposit with flowing ground water. Water vapor may have been generated by boiling of the water in the moving avalanche by heat generated from interparticle friction (Goguel, 1978). The juvenile material in the avalanche must have contained juvenile gases that were released as the fragile juvenile clasts (which were probably much hotter than $100^{\circ} \mathrm{C}$; Banks and Hoblitt, 1981) broke apart during transport. But the measured temperatures of the debris avalanche just after deposition, which probably approximate emplacement temperatures, $\left(<100{ }^{\circ} \mathrm{C}\right.$, average 60 ${ }^{\circ} \mathrm{C}$ ), suggest that water vapor and juvenile gases, which have temperatures $100{ }^{\circ} \mathrm{C}$ or greater, were not so volumetrically important as air. Air was probably incorpo- 
rated during the initial rockslide movement when the material was dilated by about 20 percent.

The flow of debris-avalanche blocks can be considered a grain flow (Bagnold, 1954; Lowe, 1976; Savage, 1984), where particles - either the debris-avalanche blocks or the clasts within the debris-avalanche blocks collide and create dispersive stresses normal to the movement of the flowing material. The dispersive stress preserves the dilation of the material, and it is the dilation that enables it to flow. This certainly fits the description of mechanical fluidization in the sense of McSaveney (1978). However, although the particles vibrate and collide, in the block facies they commonly keep at or near their original positions relative to one another, resulting in parts of the deposit retaining original volcanic structures or stratigraphy (type I windows, see "Texture of the Deposit"). This implies that particles only infrequently lose contact with one another, similar to particle interaction in flows of material in a quasi-static, rate-independent plastic regime (Savage, 1984). Original structures in deposits are cited by Melosh (1983) in support of a hypothesis of "acoustic fluidization," where sound waves drive particles apart.

As particles are frequently in contact with one another, the material could not have lost all its strength when it was dilated. The high degree of interparticle friction implies a strength of material that resulted in levees, flow fronts, and longitudinal ridges. These features are also seen in poorly fluidized pyroclastic flows (Wilson, 1980).

The density data from the Mount St. Helens avalanche deposit indicate that dilation of material occurred primarily during the rockslide, and that dilation was partly responsible for the development of avalanche flow. Davies (1982), McSaveney (1978), Melosh (1983), and Savage (1984) suggest that high rates of shear at the base of debris avalanches may cause locally high dilation and reduction of internal friction; alternatively, some experimental work (Hungr and Morgenstern, 1984) suggests that this effect may not be important. During the flow of the Mount St. Helens debris avalanche, basal shear or the intense seismic activity (which was probably created by basal shear; Voight and others, 1983) likely created dispersive pressure that preserved the dilation and was responsible for the continued flow of the avalanche.

Internal friction was also reduced by pore fluids. The most important of these was water in liquid or vapor form. Water in the liquid phase is nearly incompressible relative to air, so it probably reduces the number and (or) intensity of interparticle collisions and decreases the momentum transfer of each collision and thereby lowers internal frictional resistance to flow (Richard Iverson, oral commun., 1986). When water explosively trans-

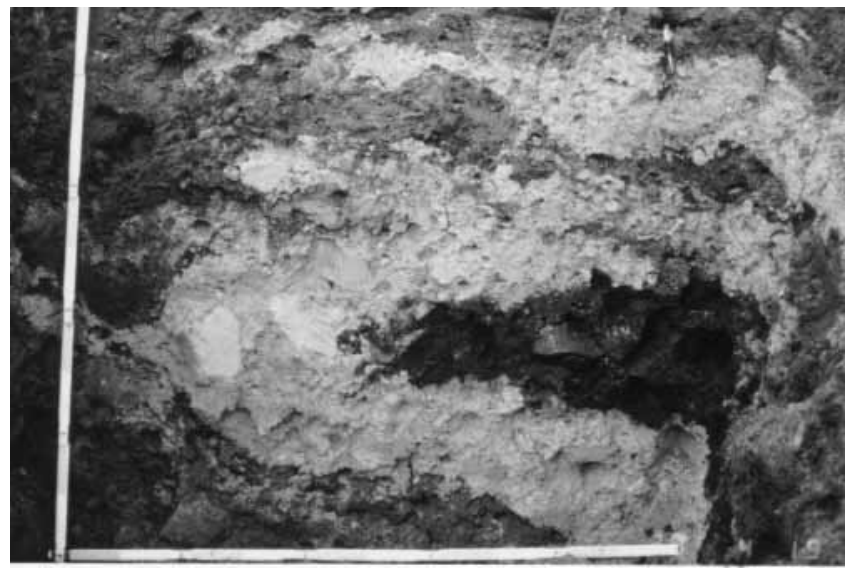

Figure 64. Disaggregation and rolling of material that may indicate first stages of turbulence. Window 827-7 near Castle Lake.

forms into the vapor phase, it increases substantially in volume, and this expansion has the effect of driving particles apart. This increases dilation and likewise lowers internal friction.

\section{TURBULENCE}

Flows of material of high concentration and high strength are generally thought to behave in a nonturbulent (or laminar) fashion (Fisher, 1971; Johnson, 1970). Turbulent flows have nonparallel lines of flow, mix together materials in different parts of the moving flow, and are erosive. It has been shown (for example, Bagnold, 1955) that increasing a concentration of particulate matter in a flow of water inhibits turbulence. Johnson (1970) pointed out that debris flows often flow with well-defined "plugs" in which particles move in parallel paths.

Turbulence is a concept generally applied to flows of viscous fluids. When disturbances in the lines of flow of a fluid develop, and the viscous forces cannot dampen these disturbances, the disturbances propagate through the fluid and the fluid is said to be turbulent (Rouse, 1946). A flow of sediment-laden water may approximate a viscous fluid, but a grain flow like the debris avalanche is not a viscous fluid; nevertheless, the concept of turbulence has been applied to grain flows (for example, Enos, 1977).

There is good evidence that parts of the flowing debris avalanche had many of the characteristics of turbulent flows during transport. Although many debris-avalanche blocks retained their coherency, suggesting parallel paths and therefore laminar flow, many blocks disaggregated and mixed together. This mixing is one of the processes that created the matrix facies. In order to mix together, the particles must have followed nonparallel paths. In addition, some exposures (for example, 827-7; 


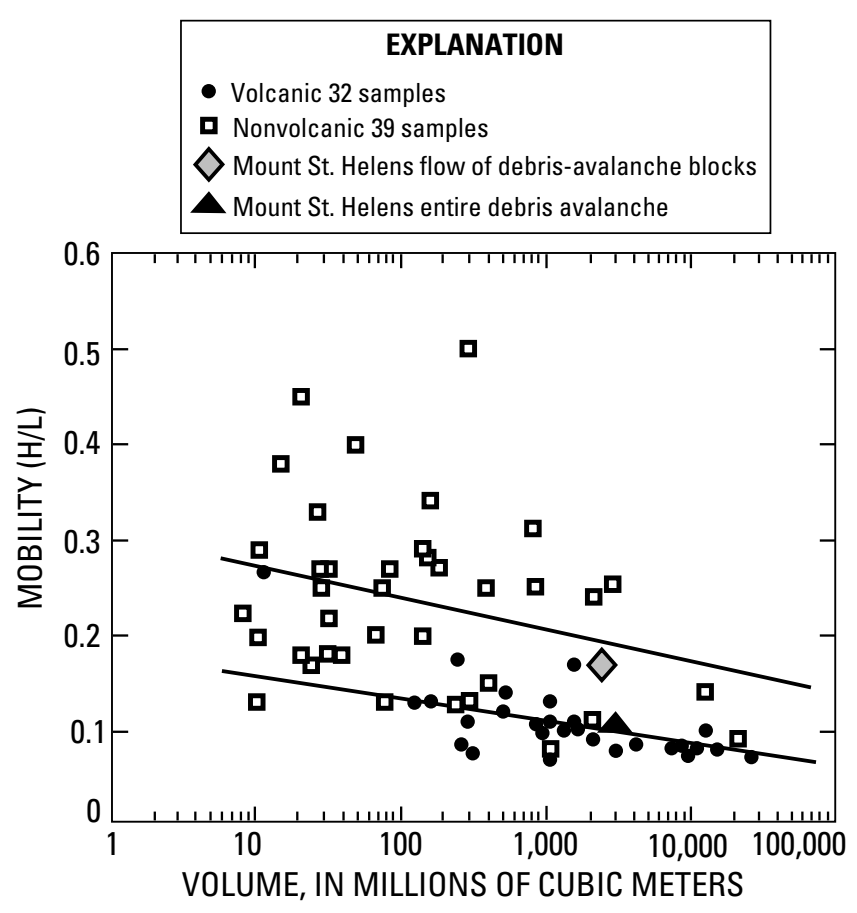

Figure 65. Mobility (fall height/travel distance; $H / L$ ) versus volume for volcanic and nonvolcanic debris avalanches (from Voight and others, 1985). Lower $H / L$ value implies greater mobility for entirety of Mount St. Helens avalanche deposit than for flow of debris-avalanche blocks. Regression lines from Voight and others (1985).

figs. 50 and 64) show disaggregation and rolling of material, and this may imply the first stages of turbulence, where swirls and vortices develop from instabilities in the fluid (Roshko, 1976; Cantwell, 1981).

\section{THE BASE OF THE DEBRIS AVALANCHE}

There may locally have been some slip along an easily sheared layer at the base of the moving debris avalanche. The gas-rich blast surge deposit may have been this easily sheared basal layer; its hot $\left(>100{ }^{\circ} \mathrm{C}\right.$; Banks and Hoblitt, 1981), gas-rich nature suggests that gas was present between particles after deposition, preserving a high degree of dilation. However, the irregular topography of the bottom of the valley of the North Fork Toutle River before the eruption indicates that the basal layer could not have been a continuous sheet. In any case, an easily sheared basal layer is certainly not required to explain any features of the debris-avalanche flow or of the debris-avalanche deposit.

A mechanism of lubrication of large debris avalanches by an easily sheared basal layer of entrapped air has been called upon to explain features of large-scale mass movements (Shreve, 1968; Fahnestock, 1978). This mechanism has been disputed on theoretical grounds by Hsu $(1975,1978)$ and Voight and Pariseau (1978).

There is no evidence of air-layer lubrication for the Mount St. Helens debris avalanche. Shreve (1968) noted that for such a layer to form, the source material must be launched into the air and then travel along relatively smooth slopes as a nearly nondeforming sheet of sliding rubble. At Mount St. Helens, the rockslide-debris avalanche scoured the north side of the mountain (fig. 27); the obvious contact with the underlying surface shows it could not have been launched into the air. The area of deposition was not smooth; instead it was the extremely irregular topography of Johnston Ridge and the North Fork Toutle River. Finally, there is abundant evidence that the sliding rubble was dilated, smashed against the ridge just north of the mountain, took a $90^{\circ}$ left turn, then traveled down the valley as a flow of debris-avalanche blocks and a poorly fluidized pyroclastic flow; therefore it cannot be considered to be a nondeforming, sliding sheet of rubble.

\section{MOBILITY OF THE DEBRIS AVALANCHE}

Many authors (for example, Siebert, 1984; Voight and others, 1983, 1985; and Ui, 1983) have noted that large volcanic debris avalanches have greater mobility (lower ratio of fall height $H$ to travel distance $L$ ) than nonvolcanic debris avalanches of comparable size. This difference is thought to result from the depressurization of magmatic and (or) hydrothermal systems (blasts) that generally accompany the emplacement of the avalanches. The unconsolidated or poorly consolidated material of stratovolcanoes may be finer grained than rocks that make up other mountains; this may also contribute to the mobility of the volcanic events (Ui, 1983), perhaps by promoting grain flow or by producing a high porosity that would allow the source areas of volcanic debris avalanches to have relatively high water contents (Barry Voight, written commun., 1985).

At Mount St. Helens, the flow of matrix facies with suspended debris-avalanche blocks traveled $29 \mathrm{~km}$ from the source, whereas the flow of debris-avalanche blocks without matrix facies traveled only $17 \mathrm{~km}$ from the source. Juvenile debris in the matrix facies material is evidence that the greater mobility resulted from the depressurizing magmatic and hydrothermal system (the blast explosions). The greater mobility may have resulted partly from the presence of juvenile and hydrothermal gasses, and their presence probably contributed to the reduction of interparticle friction. Explosive mixing also probably contributed to mobility by promoting dilation and grain flow. 
The entire Mount St. Helens avalanche, including the matrix facies, is more mobile than the flow of debris-avalanche blocks (shown on fig. 65, plot of $H / L$ versus volume from Voight and others, 1985). The entire Mount St. Helens deposit plots within the more mobile field of volcanic debris avalanches, and the flow of debris-avalanche blocks plots within the field of nonvolcanic debris avalanches (see fig. 65). This evidence supports the idea that the greater mobility of volcanic debris avalanches may result, at least in part, from associated blast explosions.

\section{REFERENCES CITED}

American Society for Testing of Materials (ASTM), 1977, Standard test method for density of soil in place by the sand-cone method, in American Society for Testing of Materials, Annual book of ASTM standards, part 19, p. 208-211.

Bagnold, R.A., 1954, Experiments on a gravity-free dispersion of large solid spheres in a Newtonian fluid under shear: Proceedings of the Royal Society of London, series A, v. 225, p. 49-63.

------, 1955, Some flume experiments on large grains but little denser than the transporting fluid, and their implications: Proceedings of the Institution of Civil Engineers, part 3, v. 4, p. 174-205.

Banks, N.G., and Hoblitt, R.P., 1981, Summary of temperature studies of 1980 deposits, in Lipman, P.W., and Mullineaux, D.R., eds., The 1980 eruptions of Mount St. Helens, Washington: U.S. Geological Survey Professional Paper 1250, p. 295-314.

Bates, R.L., and Jackson, J. A., eds., 1980, Glossary of Geology ( $2 \mathrm{~d}$ ed.) Falls Church, Va.: American Geological Institute, $749 \mathrm{p}$.

Brugman, M.M., and Meier, M.F., 1981, Response of glaciers to the eruptions of Mount St. Helens, in Lipman, P.W., and Mullineaux, D.R., eds., The 1980 eruptions of Mount St. Helens, Washington: U.S. Geological Survey Professional Paper 1250, p. 743-756.

Cantwell, B.J., 1981, Organized motion in turbulent flow: Annual Reviews of Fluid Mechanics, v. 13, p. 457-515.

Chayes, Felix, 1956, Petrographic modal analysis: New York, John Wiley, 73 p.

Christiansen, R.L., and Peterson, D.W., 1981, Chronology of the 1980 eruptive activity, in Lipman, P.W., and Mullineaux, D.R., eds., The 1980 eruptions of Mount St. Helens, Washington: U.S. Geological Survey Professional Paper 1250, p. 17-30.

Crandell, D.R., 1971, Postglacial lahars from Mount Rainier volcano, Washington: U.S. Geological Survey Professional Paper 677, 75 p.
Crandell, D.R., Miller, C.D., Glicken, H.X., Christiansen, R.L., and Newhall, C.G., 1984, Catastrophic debris avalanche from ancestral Mount Shasta volcano, California: Geology, v. 12, p. 143-146.

Criswell, C.W., 1984, Depositional facies of the May 18, 1980, pumiceous pyroclastic-flow deposits at Mount St. Helens: Workshop on volcanic blasts, Mount St. Helens, August 13-17, 1984, Program and Abstracts.

Criswell, C.W., 1987, Chronology and pyroclastic stratigraphy of the May 18, 1980, eruption of Mount St. Helens, Washington: Journal of Geophysical Research, v. 92, p. 10,237-10,266

Cummans, John, 1981, Chronology of mudflows in the South Fork and North Fork Toutle Rivers following the May 18 eruption, in Lipman, P.W., and Mullineaux, D.R., eds., The 1980 eruptions of Mount St. Helens, Washington: U.S. Geological Survey Professional Paper 1250, p. 479-488.

Davies, D.K., Quearry, M.W., and Bonis, S.B., 1978, Glowing avalanches from the 1974 eruption of the volcano Fuego, Guatemala: Geological Society of America Bulletin, v. 89, p. 369-384.

Davies, T.R.H., 1982, Spreading of rock avalanche debris by mechanical fluidization: Rock Mechanics, v. 15, p. 924.

Dzurisin, Daniel, Denlinger, R.P., and Rosenbaum, J.G., 1990, Cooling rate and thermal structure determined from progressive magnetization of the dacite dome at Mount St. Helens, Washington: Journal of Geophysical Research, v. 95, p. 2763-2780.

Endo, E.T., Malone, S.D., Noson, L.L., and Weaver, C.S., 1981, Locations, magnitudes and statistics of the March 20-May 18 earthquake sequence, in Lipman, P.W., and Mullineaux, D.R., eds., The 1980 eruptions of Mount St. Helens, Washington: U.S. Geological Survey Professional Paper 1250, p. 93-107.

Enos, Paul, 1977, Flow regimes in debris flow: Sedimentology, v. 24, p. 133-142.

Evarts, R.C., Ashley, R.P., and Smith, J.G., 1987, Geology of the Mount St. Helens area: record of discontinuous volcanic and plutonic activity in the Cascade arc of southern Washington: Journal of Geophysical Research, v. 92 , p. $10,155-10,169$.

Ewart, A., 1982, The mineralogy and petrology of TertiaryRecent orogenic volcanic rocks, with special reference to the andesite-basaltic compositional range, in Thorpe, R.S., ed., Andesites: Orogenic andesites and related rocks: New York, John Wiley, p. 25-95.

Fahnestock, R.K., 1978, Little Tahoma Peak rockfalls and avalanches, Mount Rainier, Washington, in Voight, Barry, ed., Rockslides and avalanches 1, natural phenomena: Amsterdam, Elsevier, p. 181-196.

Fairchild, L.H., 1985, Lahars at Mount St. Helens, Washington: University of Washington, Seattle, Wash., Ph.D. dissertation, $374 \mathrm{p}$. 
------, 1987, The importance of lahar initiation processes, in Costa, J.E., and Wieczorek, G.F., eds., Debris flows/ avalanches: process, recognition, and mitigation: Geological Society of America Reviews in Engineering Geology, v. 7, p. 51-61.

Fairchild, L.H., and Wigmosta, Mark, 1983, Dynamic and volumetric characteristics of the 18 May 1980 lahars on the Toutle River, Washington, in Proceedings of the symposium on erosion control in volcanic areas, Technical Memorandum of the Public Works Research Institute, Ministry of Construction, Government of Japan, p. 131-154.

Fisher, R.V., 1971, Features of coarse-grained, high-concentration fluids and their deposits: Journal of Sedimentary Petrology, v. 41, p. 916-927.

Fisher, R.V., Glicken, H.X, and Hoblitt, R.P., 1987, May 18, 1980, Mount St. Helens deposits in South Coldwater Creek, Washington: Journal of Geophysical Research, v. 92 , p. 10,267-10,283.

Fisher, R.V., and Heiken, Grant, 1982, Mount Pelee, Martinique; May 8 and 20, 1902 pyroclastic flows and surges: Journal of Volcanology and Geothermal Research, v. 13, p. 339-371.

Fisher, R.V., and Schmincke, H.U., 1984, Pyroclastic rocks: New York, Springer-Verlag, 472 p.

Fiske, R.S., Hopson, C.A., and Waters, A.C., 1963, Geology of Mount Rainier National Park, Washington: U.S. Geological Survey Professional Paper 444, p. 1-93.

Folk, R.L., 1966, A review of grain-size parameters: Sedimentology, v. 6, p. 73-93.

------, 1974, Petrography of sedimentary rocks: Austin, Texas, Hemphill Publishing Co., 182 p.

Folk, R.L., and Ward, W.C., 1957, Brazos River Bar, a study in the significance of grain-size parameters: Journal of Sedimentary Petrology, v. 27, p. 3-27.

Foxworthy, B.L., and Hill, Mary, 1982, Volcanic eruptions of 1980 at Mount St. Helens - the first 100 days: U.S. Geological Survey Professional Paper 1249, 125 p.

Galehouse, J.S., 1971, Point counting, in Carver, R.E., ed., Procedures in sedimentary petrology: New York, Wiley Interscience, p. 385-408.

Gillham, R.W., 1984, The capillary fringe and its effect on water-table response: Journal of Hydrology, v. 67, p. 307-324.

Glicken, Harry, 1986, Rockslide-debris avalanche of May 18, 1980, Mount St. Helens Volcano, Washington: University of California, Santa Barbara, Calif., Ph.D. dissertation, $303 \mathrm{p}$.

Glicken, Harry, Meyer, William, and Sabol, Martha, 1989, Geology and ground-water hydrology of Spirit Lake blockage, Mount St. Helens, Washington, with implications for lake retention: U.S. Geological Survey Bulletin 1789,33 p.

Glicken, Harry, Voight, Barry, and Janda, R.J., 1981, Rockslide-debris avalanche of May 18, 1980, Mount St.
Helens Volcano, in Abstracts, 1981 International Association of Volcanology and Chemistry of the Earth's Interior, Symposium on Arc Volcanism, p. 109-110.

Gorshkov, G.S., and Dubik, Y.M., 1970, Gigantic directed blast at Shiveluch Volcano (Kamchatka): Bulletin Volcanologique, v. 34, p. 262-288.

Goguel, J., 1978, Scale-dependent rockslide mechanisms, with emphasis on the role of pore fluid vaporization, in Voight, Barry, ed., Rockslides and avalanches 1, natural phenomena: Amsterdam, Elsevier, p. 693-705.

Gullidge, E.J., chairman, 1970, Comprehensive framework study of water and related lands: Pacific Northwest River Basins Commission, 1,022 p.

Hammond, P.E., 1980, Reconnaissance geologic map and cross sections of southern Washington Cascade Range: Portland, Oreg., Portland State University, Publications of the Department of Earth Sciences.

Heliker, C.C., 1984, Inclusions in the 1980-83 dacite of Mount St. Helens, Washington: Western Washington University, Bellingham, Wash., M.S. thesis, 185 p. , 1995, Inclusions in Mount St. Helens dacite erupted from 1980 through 1983: Journal of Volcanology and Geothermal Research, v. 66, p. 115-135.

Hoblitt, R.P., Crandell, D.R., and Mullineaux, D.R., 1980, Mount St. Helens eruptive behavior during the past 1,500 years: Geology, v. 8, p. 555-559.

Hoblitt, R.P., and Harmon, R.S., 1993, Bimodal density distribution of cryptodome dacite from the 1980 eruption of Mount St. Helens, Washington: Bulletin of Volcanology, v. 55, p. 421-437.

Hoblitt, R.P., Miller, C.D., and Vallance, J.W., 1981, Origin and stratigraphy of the deposit produced by the May 18 directed blast, in Lipman, P.W., and Mullineaux, D.R., eds., The 1980 eruptions of Mount St. Helens, Washington: U.S. Geological Survey Professional Paper 1250, p. 401-420.

Hopson, C.A., and Melson, W.G., 1982, Stratigraphy of Mount St. Helens crater walls: Eos, Transactions of the American Geophysical Union, v. 63, p. 1144.

Hopson, C.A., and Melson, W.G., 1985, Kalama eruptive cycle at Mount St. Helens: University of California, Santa Barbara, Calif., Department of Geological Sciences, Annual Research Review, June 1985.

Horz, Friedrich, Ostertag, Rolf, and Rainey, D.A., 1983, Bunte Breccia of the Ries: Continuous deposits of large impact craters: Reviews of Geophysics and Space Physics, v. 21, p. 1667-1725.

Hsu, K.J., 1975, Catastrophic debris streams (sturzstroms) generated by rockfalls: Geological Society of America Bulletin, v. 86, p. 129-140.

, 1978, Albert Heim: Observations on landslides and relevance to modern interpretations, in Voight, Barry, ed., Rockslides and avalanches 1, natural phenomena: Amsterdam, Elsevier, p. 71-93. 
Hungr, O., and Morgenstern, N.R., 1984, Experiments on the flow behavior of granular materials at high velocity in an open channel: Geotechnique, v. 34, p. 405-413.

Inman, D.L., 1952, Measures describing the size distribution of sediments: Journal of Sedimentary Petrology, v. 22, p. 125-145.

Janda, R.J., Scott, K.M., Nolan, K.M., and Martinson, H.A., 1981, Lahar movement, effects, and deposits, in Lipman, P.W., and Mullineaux, D.R., eds., The 1980 eruptions of Mount St. Helens, Washington: U.S. Geological Survey Professional Paper 1250, p. 461478.

Jaeger, J.C., and Cook, N.G.W., 1979, Fundamentals of rock mechanics (3d ed.): London, Chapman and Hall, 169 p.

Johnson, A.M., 1970, Physical processes in geology: San Francisco, Freeman, Cooper, and Co., 577 p.

Johnson, A.M., and Rodine, J.R., 1984, Debris flow, in Brunsden, D., and Prior, D.B., eds., Slope instability: New York, John Wiley, p. 257-361.

Jordan, Raymond, and Kieffer, H.H., 1981, Topographic changes at Mount St. Helens--large-scale photogrammetry and digital terrain models, in Lipman, P.W., and Mullineaux, D.R., eds., The 1980 eruptions of Mount St. Helens, Washington: U.S. Geological Survey Professional Paper 1250, p. 135-142.

Kadomura, Hiroshi, Okada, Hiromu, Imagawa, Toshiaki, Moriya, Ichio, and Yamamoto, Hiroshi, 1983, Erosion and mass movements on Mt. Usu accelerated by crustal deformation that accompanied its 1977-1982 volcanism: Journal of Natural Disaster Science, v. 5, p. 3362.

Kanamori, Hiroo, and Given, J.W., 1982, Analysis of longperiod seismic waves excited by the May 18, 1980, eruption of Mount St. Helens - A terrestrial monopole?: Journal of Geophysical Research, v. 87, p. 5422-5432.

Kelley, J.C., 1971, Mathematical analysis of point count data, in Carver, R.E., ed., Procedures in sedimentary petrology: New York, Wiley-Interscience, p. 409-426.

Kieffer, S.W., 1981, Fluid dynamics of the May 18 blast at Mount St. Helens, in Lipman, P.W., and Mullineaux, D.R., eds., The 1980 eruptions of Mount St. Helens, Washington: U.S. Geological Survey Professional Paper 1250, p. 379-400.

Kittleman, L.R., 1964, Application of Rosin's distribution in size-frequency analysis of clastic rocks: Journal of Sedimentary Petrology, v. 34, p. 483-502.

Kobayashi, Tetsuo, Hayakawa, Yukio, and Aramaki, Shigeo, 1983, Thickness and grain-size distribution of the Osumi Pumice Fall Deposit from the Aira Caldera: Bulletin of the Volcanological Society of Japan, v. 28, p. 129-140.

Kojan, E., and Hutchinson, J.N., 1978, Mayunmarca rockslide and debris flow, Peru, in Voight, Barry, ed., Rock- slides and avalanches 1, natural phenomena: Amsterdam, Elsevier, p. 315-361.

Komorowski, J.C., Glicken, H.X, and Sheridan, M.F., 1991, Secondary electron imagery of microcracks and hackly fracture surfaces in sand-size clasts from the 1980 Mount St. Helens debris-avalanche deposit: Implications for particle-particle interactions: Geology, v. 19, p. 261-264.

Krimmel, R.M., and Post, Austin, 1981, Oblique aerial photography, March-October 1980, in Lipman, P.W., and Mullineaux, D.R., eds., The 1980 eruptions of Mount St. Helens, Washington: U.S. Geological Survey Professional Paper 1250, p. 31-52.

Lipman, P.W., 1981, compiler, Geologic map of proximal deposits and features of 1980 eruptions of Mount St. Helens, Washington, in Lipman, P.W., and Mullineaux, D.R., eds., The 1980 eruptions of Mount St. Helens, Washington: U.S. Geological Survey Professional Paper 1250, plate 1.

Lipman, P.W., Moore, J.G., and Swanson, D.A., 1981, Bulging of the north flank before the May 18 eruption -Geodetic data, in Lipman, P.W., and Mullineaux, D.R., eds., The 1980 eruptions of Mount St. Helens, Washington: U.S. Geological Survey Professional Paper 1250, p. 143-156.

Lowe, D.R., 1976, Grain flow and grain-flow deposits: Journal of Sedimentary Petrology, v. 46, p. 188-199.

Major, J.J., 1984, Geologic and rheologic characteristics of the May 18, 1980 southwest flank lahars at Mount St. Helens, Washington: The Pennsylvania State University, State College, Penn., M.S. thesis, 225 p.

-, 1996, Experimental studies of deposition by debris flows: Process, characteristics of deposits, and effects of pore-fluid pressure: University of Washington, Seattle, Wash., Ph.D. dissertation, 341 p.

Major, J.J., and Voight, Barry, 1986, Sedimentology and clast orientations of the 18 May 1980 southwest-flank lahars, Mount St. Helens, Washington: Journal of Sedimentary Petrology, v. 56, p. 691-705.

Malone, S.D., Endo, E.T., Weaver, C.S., and Ramey, J.W., 1981, Seismic monitoring for eruption prediction, in Lipman, P.W., and Mullineaux, D.R., eds., The 1980 eruptions of Mount St. Helens, Washington: U.S. Geological Survey Professional Paper 1250, p. 803-814.

Malone, S.D., and Pavlis, G.L., 1983, Velocity structure and relocation of earthquakes at Mount St. Helens: Eos, Transactions of the American Geophysical Union, v. 64, p. 895.

McSaveney, M.J., 1978, Sherman glacier rock avalanche, Alaska, in Voight, Barry, ed., Rockslides and avalanches 1, natural phenomena: Amsterdam, Elsevier, p. 197-258.

Melosh, H.J., 1983, Acoustic fluidization: American Scientist, v. 71, p. 158-165. 
Meyer, William, and Carpenter, P.J., 1982, Filling of Spirit Lake, Washington, May 18, 1980, to July 31, 1982: U.S. Geological Survey Open-File Report 82-771, 19 p.

Mimura, Koji, and Kawachi, Shimpei, 1981, Nirasaki debris avalanche, a catastrophic event at the Yatsugatake volcanic chain, central Japan, in Abstracts, 1981 International Association of Volcanology and Chemistry of the Earth's Interior, Symposium on Arc Volcanism, p. 237.

Mimura, Koji, Kawachi, Shimpei, Fujimoto, Ushio, Taneichi, Mizuho, Hyuga, Tadahiko, Ichikawa, Shigenori, and Koizumi, Mitsuaki, 1982, Debris avalanche hills and their natural remnant magnetization -- Nirasaki debris avalanche, central Japan: Journal of the Volcanological Society of Japan, v. 88, p. 653-663.

Moore, J.G., and Albee, W.C., 1981, Topographic and structural changes, March-July 1980, in Lipman, P.W., and Mullineaux, D.R., eds., The 1980 eruptions of Mount St. Helens, Washington: U.S. Geological Survey Professional Paper 1250, p. 123-134.

Moore, J.G., and Rice, C.J., 1984, Chronology and character of the May 18, 1980, explosive eruption of Mount St. Helens, in Explosive volcanism: Inception, evolution, hazards: Washington, D.C., National Academy Press, p. 133-142.

Moore, J.G., and Sisson, T.W., 1981, Deposits and effects of the May 18, 1980, pyroclastic surge, in Lipman, P.W., and Mullineaux, D.R., eds., The 1980 eruptions of Mount St. Helens, Washington: U.S. Geological Survey Professional Paper 1250, p. 421-433.

Mullineaux, D.R., and Crandell, D.R., 1981, The eruptive history of Mount St. Helens, in Lipman, P.W., and Mullineaux, D.R., eds., The 1980 eruptions of Mount St. Helens, Washington: U.S. Geological Survey Professional Paper 1250, p. 3-16.

Murai, Isumu, 1961, A study of the textural characteristics of pyroclastic flow deposits in Japan: Tokyo University Earthquake Research Institute Bulletin, v. 39, p. 133248.

Norris, R.D., 1994, Seismicity of rockfalls and avalanches at three Cascade Range volcanoes: Implications for seismic detection of hazardous mass movements: Bulletin of the Seismological Society of America, v. 84, p. 1925-1939.

Pevear, D.R., Dethier, D.P., and Frank, D., 1982, Clay minerals in the 1980 deposits from Mount St. Helens: Clays and Clay Minerals, v. 30, p. 241-252.

Pierson, T.C., 1985, Initiation and flow behavior of the 1980 Pine Creek and Muddy River lahars, Mount St. Helens, Washington: Geological Society of America Bulletin, v. 96, p. $1056-1069$.

Pierson, T.C., and Scott, K.M., 1985, Downstream dilution of a lahar: transition from debris flow to hyperconcentrated streamflow: Water Resources Research, v. 21, p. 1511-1524.
Roshko, Anatol, 1976, Structure of turbulent shear flows: a new look: American Institute of Aeronautics and Astronautics Journal, v. 14, p. 1349-1357.

Rouse, Hunter, 1946, Elementary mechanics of fluids: New York, Dover Publications, $376 \mathrm{p}$.

Rowley, P.D., Kuntz, M.A., and Macleod, N.S., 1981, Pumiceous pyroclastic flow deposits, in Lipman, P.W., and Mullineaux, D.R., eds., The 1980 eruptions of Mount St. Helens, Washington: U.S. Geological Survey Professional Paper 1250, p. 489-512.

Savage, S.B., 1984, The mechanics of rapid granular flows: Advances in Applied Mechanics, v. 24, p. 289-366.

Scott, K.M., 1988, Origins, behavior, and sedimentology of lahars and lahar-runout flows in the Toutle-Cowlitz River system: U.S. Geological Survey Professional Paper 1447-A, $76 \mathrm{p}$.

-----, 1989, Origin, behavior, and sedimentology of prehistoric catastrophic lahars at Mount St. Helens, Washington, in Clifton, H.E., ed., Sedimentologic consequences of convulsive geologic events: Geological Society of America Special Paper 229, p. 23-36.

Sharp, R.P., 1942, Mudflow levees: Journal of Geomorphology, v. 5, p. 222-227.

Shreve, R.L., 1968, The Blackhawk Landslide: Geological Society of America Special Paper, no. 108, p. 1-47.

Siebert, Lee, 1984, Large volcanic debris avalanches: Characteristics of source areas, deposits, and associated eruptions: Journal of Volcanology and Geothermal Research, v. 22, p. 163-197.

Sisson, T.W., 1982, Sedimentary characteristics of the airfall deposit produced by the major pyroclastic surge of May 18, 1980 at Mount St. Helens, Washington: University of California, Santa Barbara, Calif., M.A. Thesis, $145 \mathrm{p}$.

-, 1995, Blast ashfall deposit of May 18, 1980 at Mount St. Helens, Washington: Journal of Volcanology and Geothermal Research, v. 66, p. 203-216.

Smith, A.L, and Roobol, M.J., 1982, Andesite pyroclastic flows, in Thorpe, R.S., ed., Andesites: New York, John Wiley, p. 415-433.

Smith, D.R., 1984, The petrology and geochemistry of High Cascade Volcanics in Southern Washington: Mount St. Helens Volcano and the Indian Heaven basalt field: Rice University, Houston, Texas, Ph.D. dissertation, $409 \mathrm{p}$.

Smith, D.R., and Leeman, W.P., 1987, Petrogenesis of Mount St. Helens dacitic magmas: Journal of Geophysical Research, v. 92, p. 10,313-10,334.

Sparks, R.S.J., 1976, Grain-size variations and implications for the transport of pyroclastic flows: Sedimentology, v. 23 , p. $147-188$.

Stoffel, D.B., and Stoffel, K.L., 1980, Mount St. Helens seen close up on May 18: Geotimes, v. 25, p. 16-17.

Suzuki, Keiko, and Ui, Tadahide, 1982, Grain orientation and depositional ramps as flow direction indicators of a 
large-scale pyroclastic flow deposit in Japan: Geology, v. 10, p. 429-432.

Trask, P.D., 1930, Mechanical analysis of sediments by centrifuge: Economic Geology, v. 25, p. 581-599.

Ui, Tadahide, 1983, Volcanic debris avalanche deposits -identification and comparison with non-volcanic debris stream deposits: Journal of Volcanology and Geothermal Research, v. 18, p. 135-150.

-------, 1985, Debris avalanche deposits associated with volcanic activity: Proceedings, IVth International Conference and Field Workshop on Landslides, Tokyo, Japan, p. 405-410.

Ui, Tadahide, and Aramaki, Shigeo, 1983, Volcanic dry avalanche deposit in 1980 eruption of Mt. St. Helens, U.S.A.: Bulletin of the Volcanological Society of Japan, v. 28, p. 289-300.

Ui, Tadahide, and Glicken, Harry, 1986, Internal structural characteristics of a debris avalanche from Mount Shasta, California, U.S.A.: Bulletin of Volcanology v. 48, p. 189-194.

U.S. Board on Geographic Names, 1984, Decision list no. 8301, p. 21.

Varnes, D.J., 1978, Slope movement types and processes, in Shuster, R.L., and Krizek, R.J., eds., Landslides, analysis and control: Transportation Research Board, Special Report 176, p. 11-33.

Verhoogen, Jean, 1937, Mount St. Helens, a recent Cascade Volcano: Bulletin Department of Geological Sciences, University of California, v. 14, p. 263-309.

Voight, Barry, ed., 1978, Rockslides and avalanches 1, natural phenomena: Amsterdam, Elsevier, 826 p.

-------, 1981, Time scale for the first moments of the May 18 eruption, in Lipman, P.W., and Mullineaux, D.R., eds., The 1980 eruptions of Mount St. Helens, Washington: U.S. Geological Survey Professional Paper 1250, p. 6986.

Voight, Barry, Glicken, Harry, Janda, R.J., and Douglass, P.M., 1981, Catastrophic rockslide-avalanche of May 18, in Lipman, P.W., and Mullineaux, D.R., eds., The 1980 eruptions of Mount St. Helens, Washington: U.S. Geological Survey Professional Paper 1250, p. 347378.

Voight, Barry, Janda, R.J., Glicken, Harry, and Douglass, P.M., 1983, Nature and mechanics of the Mount St. Helens rockslide-avalanche of 18 May 1980: Geotechnique, v. 33, p. 243-273.

-------, 1985, Reply to discussion on Nature and mechanics of the Mount St. Helens rockslide-avalanche of 18 May 1980: Geotechnique, v. 35, p. 357-368.

Voight, Barry, and Pariseau, W.G., 1978, Rockslides and avalanches: an introduction, in Voight, Barry, ed., Rockslides and avalanches 1, natural phenomena: Amsterdam, Elsevier, p. 1-67.

Waitt, R.B., Jr., 1981, Devastating pyroclastic density flow and attendant air fall of May 18 - stratigraphy and sedi- mentology of deposits, in Lipman, P.W., and Mullineaux, D.R., eds., The 1980 eruptions of Mount St. Helens, Washington: U.S. Geological Survey Professional Paper 1250, p. 439-460.

Walker, G.P.L, 1971, Grain-size characteristics of pyroclastic deposits: Journal of Geology, v. 79, p. 696-714.

Walker, G.P.L., and Croasdale, R.L., 1971, Two Plinian-type eruptions in the Azores: Journal of the Geological Society of London, v. 127, p. 17-55.

Wilson, C.J.N., 1980, The role of fluidization in the emplacement of pyroclastic flows: an experimental approach: Journal of Volcanology and Geothermal Research, v. 8, p. 231-249.

Wright, J.V., Smith, A.L., and Self, S., 1980, A working terminology of pyroclastic deposits: Journal of Volcanology and Geothermal Research, v. 8, p. 315-336.

Yamaguchi, D.K., and Hoblitt, R.P., 1995, Tree-ring dating of pre-1980 volcanic flowage deposits at Mount St. Helens, Washington: Geological Society of America Bulletin, v. 107, p. 1077- 1093.

Yamaguchi, D.K., and Lawrence, D.B., 1993, Tree-ring evidence for 1842-1843 eruptive activity at the Goat Rocks dome, Mount St. Helens, Washington: Bulletin of Volcanology, v. 55, p. 264-272. 